UNIVERSIDADE DE BRASÍLIA - UNB

INSTITUTO DE GEOCIÊNCIAS - IGD

\title{
GEOQUÍMICA E PETROGRAFIA DAS FORMAÇÕES FERRÍFERAS E ROCHAS CLÁSTICAS DO GRUPO JACADIGO, NEOPROTEROZOICO DO SUL DA FAIXA PARAGUAI
}

Davi Oliveira Saldanha

DISSERTAÇÃO DE MESTRADO N 387 


\section{GEOQUÍMICA E PETROGRAFIA DAS FORMAÇÕES FERRÍFERAS E ROCHAS CLÁSTICAS DO GRUPO JACADIGO, NEOPROTEROZOICO DO SUL DA FAIXA PARAGUAI}

Davi Oliveira Saldanha

Orientador:

Prof. Dr. Reinhardt Adolfo Fuck

Coorientador:

Prof. Dr. Detlef Hans Gert Walde

Banca Examinadora:

Prof. Dr. Reinhardt Adolfo Fuck

Profa. Dra. Lucieth Cruz Vieira

Prof. Dr. Paulo César Boggiani

Brasília 
Saldanha, Davi Oliveira GEOQUÍMICA E PETROGRAFIA DAS FORMAÇÕES FERRÍFERAS E ROCHAS CLÁSTICAS DO GRUPO JACADIGO, NEOPROTEROZOICO DO SUL DA FAIXA PARAGUAI / Davi Oliveira Saldanha; orientador Reinhardt Adolfo Fuck; co-orientador Detlef Hans Gert Walde. -- Brasília, 2017. $109 \mathrm{p}$.

Dissertação (Mestrado - Mestrado em Geologia) -Universidade de Brasília, 2017.

1. Formações Ferríferas. 2. Grupo Jacadigo. 3. Faixa Paraguai. 4. Neoproterozoico. I. Fuck, Reinhardt Adolfo, orient. II. Walde, Detlef Hans Gert, co-orient. III. Título. 
"We should be cautious not to attribute to nature, laws which may perhaps be only of our own invention.'

James Hutton 


\section{Agradecimentos}

Gostaria de agradecer a Deus pela força e determinação para realizar este trabalho, assim como pela oportunidade desafiadora de estudar a geologia e a química das formações ferríferas e as rochas da região de Corumbá.

Agradeço aos meus pais, Itiberê e Sérgia, pela orientação, paciência e acolhimento durante o período de elaboração do trabalho. Ao meu irmão Tiago, pelo companheirismo e amizade nos momentos entre os trabalhos. A Tatiane Moreira pelo apoio e compreensão nos momentos decisivos e de ausência.

Agradeço ao meu orientador, Prof. Reinhardt Adolfo Fuck, pela confiança, disponibilidade e paciência, assim como pelo grande exemplo de competência e dedicação.

Agradeço ao Prof. Detlef Walde pelas conversas e conselhos firmes, que ajudaram a compreender a geologia da região, além da agradável parceria no campo.

Agradeço ao geólogo Dr. Augusto Mendonça pela ajuda e grande incentivo a dar continuidade aos meus estudos no mestrado.

Agradeço a Rafael Henchen, Gerente de Geologia da Vetorial Mineração, e ao Prof. Newton S. Gomes pela ajuda e disponibilização das amostras.

I'd like to thank Prof. Dr. Eric E. Hiatt for his advice and words of encouragement.

Agradeço à Prof. ${ }^{a}$ Lucieth Vieira e ao Prof. Márcio Pimentel pelas discussões e ajuda.

Agradeço aos meus amigos de campo em Corumbá: Leandro Silva, Geraldo Guimarães, Luiz Perin, Tati, Débora Ellen, Samuel Hayden, Willian Silva e Fernando Prezotti (Ganso), Mateus Ribeiro, Gideon, Thomas Angerer.

Agradeço aos meus amigos e parceiros na geologia: Hammel, Bernardo, Renato, Thiago, Lauro, Haroldo, Lili, Janaína, Isabela, Salomão, Mathew, Luiz Henrique, Diego, Luciana e tantos outros que me ajudaram com conselhos e palavras de apoio.

Sou grato aos professores do IGD, em especial aos Prof. Elton Dantas, Prof. Massimo Matteini, Prof. Claudinei Gouveia, Prof. ${ }^{a}$ Natalia Hauser, Prof. Valmir Silva pela ajuda e incentivo.

Por fim, agradeço ao Conselho Nacional de Desenvolvimento Científico e Tecnológico (CNPq) pela concessão da bolsa de mestrado que possibilitou a realização deste trabalho. 


\section{Resumo}

Os depósitos de formação ferrífera do Grupo Jacadigo, nas proximidades de Corumbá, constituem um dos principais depósitos de ferro formados no Neoproterozoico e se reveste de grande importância devido à sua preservação, baixo grau de metamorfismo e alto teor de ferro e manganês. As rochas químicas e detríticas do grupo correspondem a sequência sedimentar depositada sobre a porção cratônica adjacente à parte sul da Faixa Paraguai, na região onde ocorre a junção entre a faixa de dobramentos e o aulacógeno Tucavaca. As rochas do Grupo Jacadigo são divididas em duas formações, Formação Urucum, basal, composta por arenitos arcoseanos e brechas polimíticas de clastos retrabalhados do embasamento, e a Formação Santa Cruz, superior, formada por formações ferríferas hematíticas com nódulos de cherte e jaspe, intercaladas a camadas de diamictitos e arenitos ferruginosos. A Formação Santa Cruz pode ser dividida da base para o topo, em membro Córrego da Pedras de caráter transicional e local, composto por camadas de arenitos arcoseanos ricos em ferro, e membro Band'Alta, constituído por formações ferríferas nodulares e camadas de diamictitos.

O presente trabalho investigou em detalhe a estratigrafia e a geoquímica das rochas pertencentes ao Grupo Jacadigo no depósito de Santa Cruz localizado na Morraria Grande, a sudeste da Morraria do Urucum. Nessa localidade evidencia-se grande aporte de sedimentos clásticos representados por espessas camadas de diamictitos grossos, diferentemente do que é encontrado nas sequências da Morraria do Urucum. Análises petrográficas mostram que as formações ferríferas locais são preferencialmente nodulares e laminares, com restritas porções bandadas. Diferentemente do depósito do Urucum, camadas de manganês na Morraria Grande são restritas a duas exposições de pouca espessura. A análise das formações ferríferas permitiu evidenciar que processos de dolomitização inicial da sequência, alteração por fluidos ricos em Fe e Si e processos de desfluidização por compactação das camadas que afetaram a sequência nos estágios sin- e pós-deposicional.

Análises de elementos terras raras (ETRs) possibilitaram contextualizar as condições em que as formações ferríferas do Grupo Jacadigo se formaram. Os ETRs mostram que as rochas foram formadas em oceano estratificado e com condições intermediárias de oxigenação, e que os padrões de ETR destas formações ferríferas se assemelham aos da água do oceano moderno. O conjunto destas evidências leva a sugerir que as rochas da Morraria Grande foram depositadas em porção mais proximal ou mais rasa da bacia de formação do Grupo Jacadigo.

Palavras-chave: Formações Ferríferas, Grupo Jacadigo, Faixa Paraguai, Neoproterozoico. 


\section{Abstract}

The iron formation deposits of the Jacadigo Group, near Corumbá, constitute one of the main iron deposits formed in Neoproterozoic and is of great importance due to its preservation, low grade of metamorphism and high iron and manganese content. The chemical and detrital sequence that make up the group correspond to the sediments deposited on the cratonic margin adjacent to the southern part of the Paraguay Belt and in the region where the junction between the fold belt and the Tucavaca aulacogen occurs. The rocks that make up the Jacadigo Group were divided in two formations, the basal Urucum Formation, composed of arcosean sandstones and polymictic breccias from reworked material of the basement rocks, and the superior Santa Cruz Formation, composed by hematitic iron formations with chert and jasper nodules, interbedded to layers of diamictites and ferruginous sandstones. Santa Cruz Formation can be divided from bottom to top, in Córrego das Pedras member, with transitional and local nature and formed by layers of arcosean sandstones rich in iron, and Band'Alta member consisting of nodular iron formations and layers of diamictites.

The present work aimed to investigate in detail the stratigraphy and geochemistry of rocks belonging to the Jacadigo Group at the Santa Cruz deposit located in Morraria Grande, southeast of Morraria do Urucum. At this site, it is evident a great contribution of clastic sediments represented by thick layers of coarse diamictites, unlike what is found at the Urucum sequences. Petrographic analyzes show that the local iron formations are preferably nodular and laminar with restricted banded portions. Unlike the Urucum deposit, manganese layers from Morraria Grande are poorly represented at the sequence and are found with restricted thickness in only two occasions. The analysis of the iron formations revealed that initial dolomitization of the sequence, alteration by $\mathrm{Fe}$ and $\mathrm{Si}$ rich fluids and processes of fluid-loss by layers compressing, affected the sequence during sin- and post-depositional stages.

Analysis of rare earth elements (REE) made it possible to contextualize the conditions in which the iron formations of the Jacadigo Group formed. The REEs showed that the rocks were formed in a stratified ocean with intermediate oxygenation conditions, and that the REE patterns of these iron formations resemble those of modern ocean water. All this evidences leads to suggest that the rocks of Morraria Grande were deposited in a proximal and shallower context of the basin of deposition the Jacadigo group.

Keyword: Iron formation, Jacadigo Group, Paraguay Belt, Neoproterozoic. 


\section{SUMÁRIO}

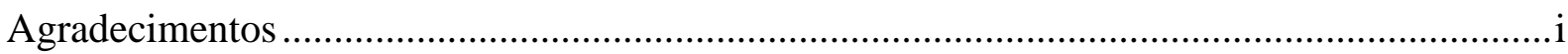

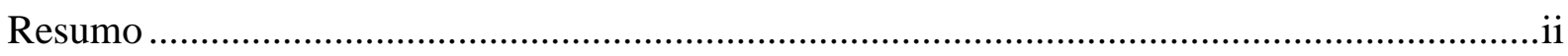

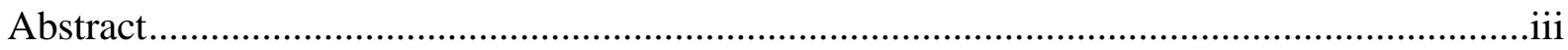

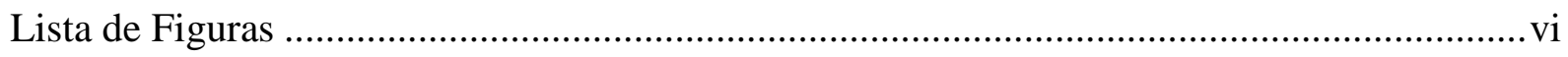

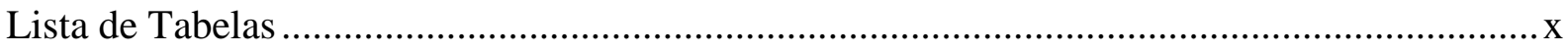

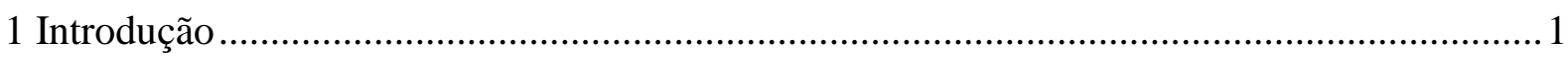

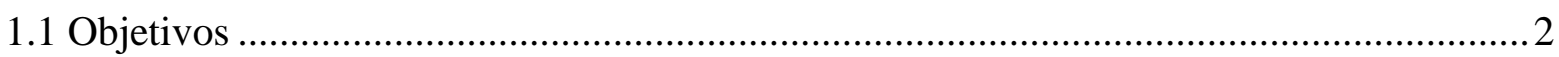

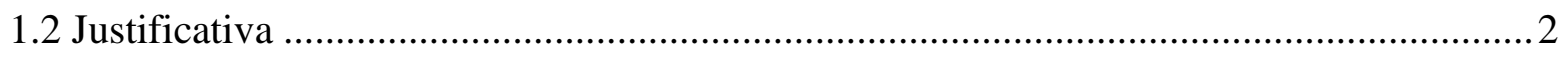

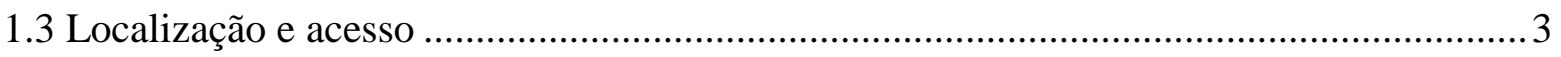

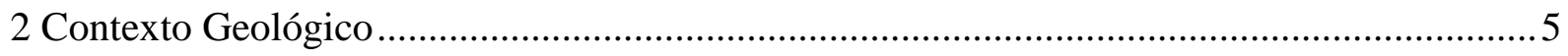

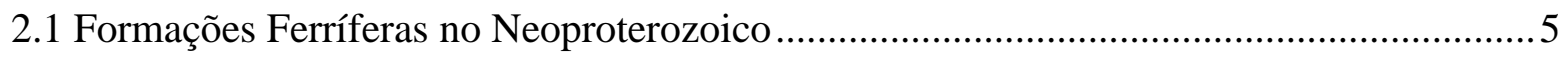

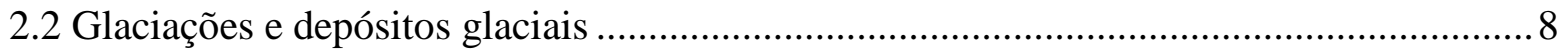

2.3 Formações Ferríferas do Grupo Rapitan .................................................................. 10

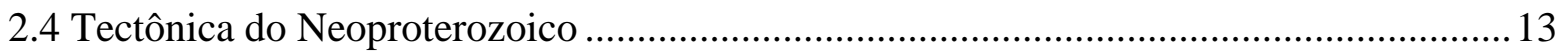

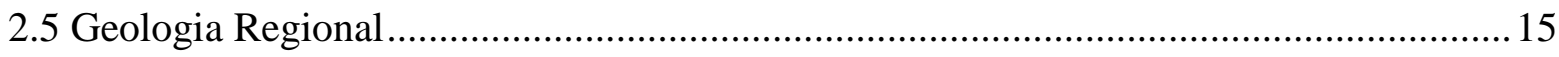

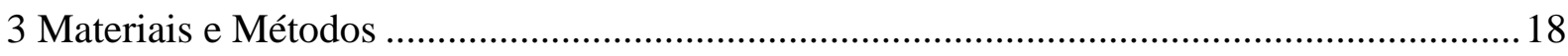

3.1 Amostragem e preparação das amostras ................................................................ 18

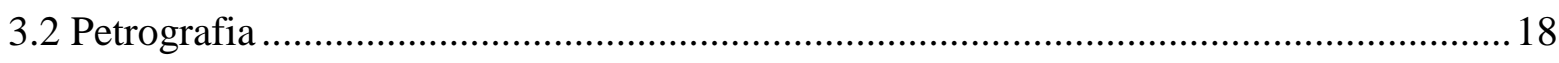

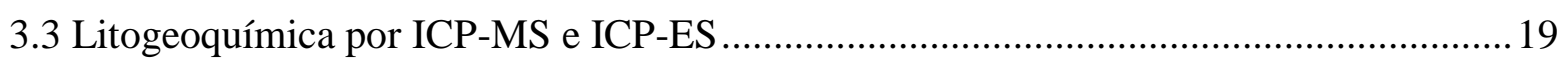

3.4 Microscópio Eletrônico de Varredura (MEV) e Sistema de Energia Dispersiva (EDS) . 19

3.5 Microssonda Eletrônica (MSE) .......................................................................... 19

4 Manuscrito: Petrografia e geoquímica das formações ferríferas e rochas clásticas do Grupo Jacadigo, Neoproterozoico do sul da Faixa Paraguai ..........................................................2 22

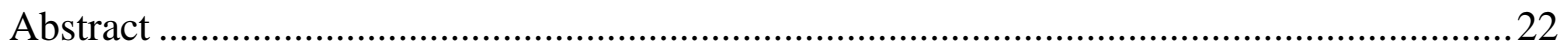




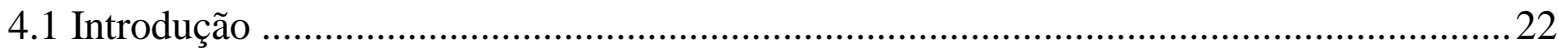

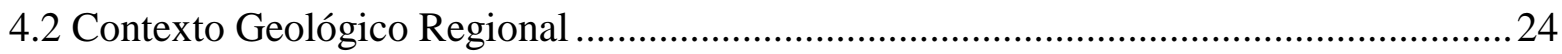

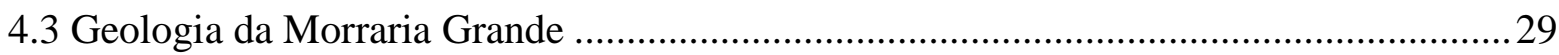

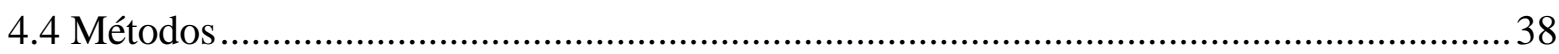

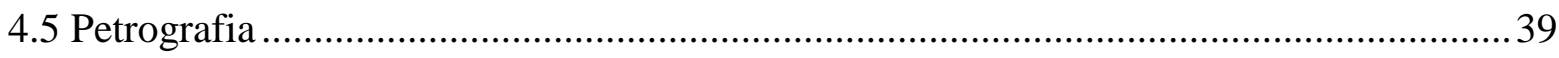

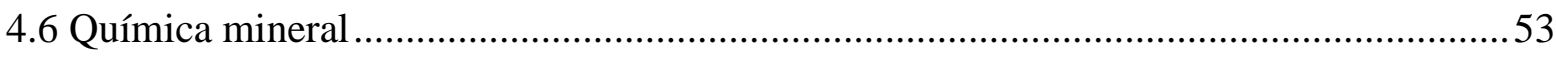

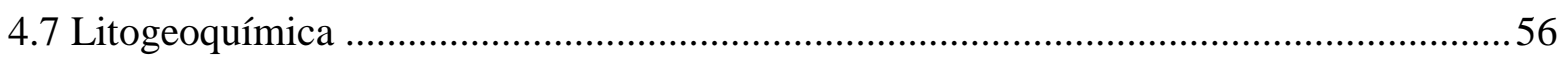

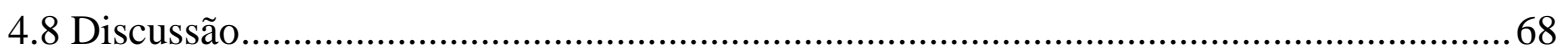

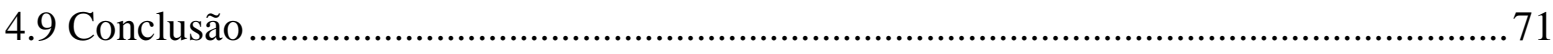

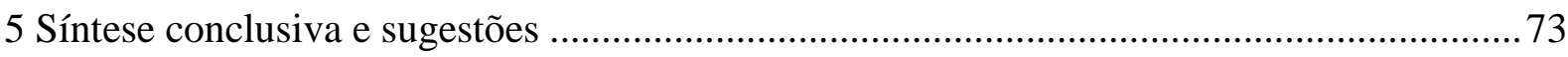

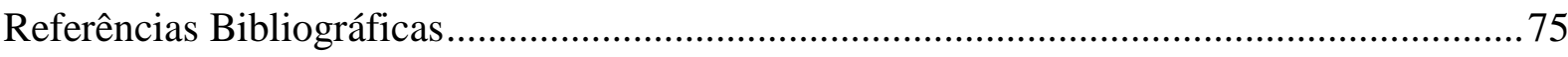

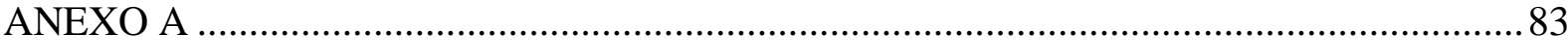

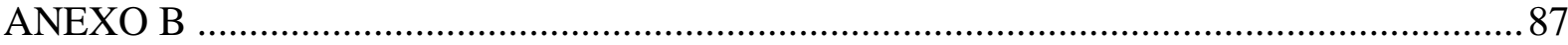




\section{Lista de Figuras}

Figura 1 - Mapa de localização da área de estudo e principais vias de acesso (relevo sombreado gerado a partir do SRTM).

Figura 2 - Abundância e exemplo de formações ferríferas distribuídas segundo o tempo geológico (modificado de Klein, 2005).

Figura 3 - (A) Mapa de localização e (B) mapa geológico com as ocorrências do Supergrupo Windermere e as rochas do Grupo Rapitan, (1) Snake River, (2) Redstone River (Baldwin et al., 2012).

Figura 4 - Coluna estratigráfica da região das Montanhas Mackenzie e destaque para o Grupo Rapitan (Young, 1976; Baldwin et al., 2012).

Figura 5 - Representação paleogeográfica de continentes no Neoproterozoico (Hoffman, 1991).

Figura 6 - Mapa da Faixa Paraguai (modificado de Alvarenga \& Trompette, 1993), retângulo vermelho marca área de estudo (esquerda) e mapa geológico da região de Corumbá (direita) (modificado de Weiss \& Sweet, 1959; Walde, 1988; Freitas et al., 2011).

Figura 7 - Mapa simplificado da porção sudeste do Cráton Amazônico e do Bloco Rio Apa, com destaque para as coberturas cratônicas e a Faixa Paraguai (modificado de Alvarenga \& Trompette, 1993). Linhas pontilhadas - Limites das zonas da Faixa Paraguai; Linha tracejada/pontilhada - Eixo do Aulacógeno Tucavaca. Y granitos (1) São Vicente; (2) Coxim; (3) Rio Negro; (4) Taboco.

Figura 8 - Coluna estratigráfica da região de Corumbá com as unidades mapeáveis e respectivas idades. CP - Córrego das Pedras. Modificado de Haralyi \& Walde (1986), Urban et al. (1992) e Piacentini et al. (2013).

Figura 9 - Mapa Geológico da região de Corumbá (modificado de Weiss \& Sweet, 1959;

Walde, 1988; Freitas, 2010).

Figura 10 - Amostras de testemunho de sondagem: (A) camada de brechas da Formação Urucum, com clastos de mármore e de granito; (B) arenito arcoseano médio/grosso que ocorre acima dos intervalos de brecha. Porções avermelhadas de óxido de ferro podem ser observadas. 
Figura 11 - Amostras de testemunho de sondagem: (A) formação ferrífera nodular com nódulos de cherte/jaspe e nódulos substituídos por hematita especular formando a matriz; (B) nódulos menores substituídos compondo a matriz hematítica, com porções nodulares jaspilíticas ocorrem preservadas.

Figura 12 - Afloramento em bancada com formação ferrífera bandada com camadas e lâminas limonitizadas (cor amarela). Estrutura de slump cortada por veios de quartzo posteriores, região próximo a falha. Caneta à direita como escala.

Figura 13 - Bloco de formação ferrífera bandada, apresentando bandas de cherte e hematita bem definidas, com estrutura de slump.

Figura 14 - Amostra de mão obtida de afloramento em região onde ocorre brechação hidráulica dentro do depósito; na matriz jaspilítica (vermelha) ocorrem pequenos cristais de hematita.

Figura 15 - Afloramento em bancada mostrando camada de diamictito ferruginoso grosso localizado na parte superior da Morraria Grande. Porções eluvionares e coluvionares de formação ferrífera recobrem o material.

Figura 16 - Dropstone de granito em meio a arenito ferruginoso fino, afloramento em bancada da mina da Vetorial, Morraria Grande. Detalhe para diferença na deformação por queda de bloco nas camadas abaixo e deformação por compactação nas camadas acima do bloco.

Figura 17 - Mapa com a localização dos furos de sondagem (SC; MG; UB) e as Morrarias adjacentes à Morraria Grande (1 - Morraria do Urucum; 2 - Morraria de Santa Cruz; 3 - Morraria do Rabichão).

Figura 18 - Furos de sondagem utilizados (MG, UB e SC) do depósito da Morraria Grande. Furo MG com seu respectivo perfil geoquímico para ferro, sílica, alumínio, titânio e cálcio (suporte amostral de 5m).

Figura 19 - Fácies nodular mostrando nódulos de cherte com início de substituição por hematita. A hematita se forma inicialmente no contato e no centro dos nódulos. XPL, Luz refletida e transmitida.

Figura 20 - Formação ferrífera nodular parcialmente substituída por hematita especular. Notar deformação dos nódulos após a substituição na parte superior e a porção preservada de nódulos de cherte na parte inferior. Hematita ocorre no contato 
dos nódulos. $\mathrm{O}$ aspecto de ferrugem na parte hematítica se dá pela preservação de diminutos cristais de cherte/jaspe em meio à matriz substituída. XPL, Luz refletida e transmitida.

Figura 21 - Estrutura de contração em pod de cherte seguido de recristalização de sílica de maior grau de cristalinidade nos espaços abertos. Parte extinta corresponde a hematita que ocorre substituindo o material. XPL, luz transmitida.

Figura 22 - Micro-grânulos de anquerita (laranja/vermelho) em porção de cherte da formação ferrífera. PPL, Luz transmitida, 40x.

Figura 23 - Esferulitos de sílica finamente cristalizada com hábito radial em amostra de formação ferrífera com níveis clásticos e jaspilíticos. PPL, Luz transmitida. 46

Figura 24 - Cristais de dolomita parcialmente preservados em meio a matriz de cherte e carbonato

Figura 25 - Pseudomorfos de dolomita substituídos por cherte e matriz substituída por hematítica na parte superior e inferior. Imagem de MEV.

Figura 26 - Matriz hematítica substituindo matriz de cherte. Nódulos de cherte semi preservados ocorrem em meio a matriz. XPL, Luz refletida e transmitida.

Figura 27 - Contato entre banda rica em hematítica e banda cherte/jaspe. Notar veio com comportamento diferenciado entre os dois materiais. XPL, luz refletida e transmitida.

Figura 28 - Formação ferrífera laminar/nodular, nódulos substituídos por hematita e deformados por achatamento. Matriz laminada ocorre entre os nódulos. XPL, Luz refletida e transmitida.

Figura 29 - Grãos substituídos por cherte em meio a matriz hematítica em intervalo laminar de amostra de formação ferrífera bandada. Imagem de MEV.

Figura 30 - Padrões de ETR+Y das amostras da região da Morraria Grande. Elementos estão ordenados em ordem decrescente de raio iônico em estado de oxidação +3 e coordenação octaédrica (Bau \& Dulski, 1996). Padrões de ETR+Y para (A) formações ferríferas puras; (B) formações ferríferas clásticas; (C) arenitos arcoseanos. 
Figura 31 - Gráfico de $\mathrm{Ce} / \mathrm{Ce}{ }^{*}(\mathrm{SN})$ vs $\mathrm{Pr} / \mathrm{Pr} *(\mathrm{SN})$ para amostras de sedimentos do Grupo Jacadigo da Morraria Grande. Números representam os campos referentes a cada anomalia. (I) sem anomalia; (II) anomalia positiva de La; (III) anomalia negativa de Ce; (IV) anomalia positiva de Ce (Bau \& Dulski, 1996; Bekker et al., 2010).

Figura 32 - Comparação dos padrões de ETRs e Y, (A) entre amostras de CIF e IF, (B) entre amostras de CIF e AS.

Figura 33 - Comparação dos padrões de ETRs e Y normalizados ao Condrito: (A) entre amostras de CIF e IF, (B) entre amostras de CIF e AS.

Figura 34 - Comparação dos padrões de ETRs e Y, (A) entre as formações ferríferas da Morrarias do Urucum, Morraria do Rabicho (Viehmann et al., 2016), Morraria Grande e da Bodoquena (Piacentini, 2008) (B) entre as formações ferríferas da Morraria Grande e do Grupo Rapitan, Canadá (Halverson et al., 2011). 


\section{Lista de Tabelas}

Tabela 1 - Dados de microssonda sobre amostras de cherte em estruturas das porções não ferruginosas das formações ferríferas.

Tabela 2 - Dados de microssonda sobre hematita que ocorre substituindo estruturas nas formações ferríferas.

Tabela 3 - Valores de elementos maiores em peso percentual de óxidos para as amostras analisadas de formações ferríferas, formações ferríferas clásticas e arenitos arcoseanos.

Tabela 4 - Coeficientes de correlação de Pearson para formações ferríferas "puras". Valores positivos que se aproximam de 1 (verde) representam correlações positivas, enquanto valores negativos próximos de -1 (vermelho) representam correlações inversamente proporcionais.

Tabela 5 - Coeficientes de correlação de Pearson para formações ferríferas clásticas. Valores positivos que se aproximam de 1 (verde) representam correlações positivas, enquanto valores negativos próximos de -1 (vermelho) representam correlações inversamente proporcionais.

Tabela 6 - Coeficientes de correlação de Pearson para arenitos arcoseanos. Valores positivos que se aproximam de 1 (verde) representam correlações positivas, enquanto valores negativos próximos de -1 (vermelho) representam correlações inversamente proporcionais

Tabela 7 - Elementos maiores e traços para amostras de formações ferríferas e sedimentos arcoseanos do Grupo Jacadigo 


\section{Introdução}

A presente dissertação visa apresentar nova contribuição sobre o contexto geológico em que se inserem as rochas próximas a Corumbá (MS) a partir de novos dados de mapeamento e geoquímicos. Estudos estratigráficos e petrológicos foram conduzidos sobre as rochas sedimentares pertencentes ao Grupo Jacadigo na região da Morraria Grande. Este grupo corresponde a sequência de rochas sedimentares de idade neoproterozoica formadas sobre a margem cratônica da parte sul da Faixa Paraguai. Sua estratigrafia é formada por arenitos e brechas arcoseanas que formam a sua base, e formações ferríferas e diamictitos no topo. $\mathrm{O}$ presente estudo deu ênfase as formações ferríferas e a parte superior dos sedimentos clásticos que formam o grupo, com o intuito de caracterizar a sequência por meio de análises geoquímicas e petrográficas.

O trabalho utilizou os dados e informações de mapeamento e de amostras de testemunho de furos de sondagem provenientes da nova mina de ferro da Vetorial Mineração Ltda. A mina de ferro de Santa Cruz é o mais recente empreendimento de exploração de ferro na região. Investigações de sondagem na Morraria Grande em 2012 mostraram espessuras de formação ferrífera muito acima do esperado para a região, o que fez com que novos estudos fossem necessários para o depósito. Os testemunhos utilizados neste trabalho são resultado da campanha de pesquisa executada entre 2012-2013 na qual o presente autor teve a oportunidade de participar no período em que trabalhou no depósito. Os dados foram disponibilizados por meio da parceria entre a empresa Vetorial Mineração e a Universidade de Brasília, que teve como finalidade promover o entendimento do depósito por meio de estudos geológicos.

A dissertação está estruturada em seis partes:

- Introdução: onde são apresentados os objetivos, justificativa, localização e acesso.

- Contexto geológico: são apresentados o contexto das formações ferríferas no neoproterozoico, as glaciações e depósitos glaciais, tectônica do Neoproterozoico, e geologia regional da Faixa Paraguai e da região de Corumbá.

- Materiais e métodos: onde estão descritos e explicados os métodos utilizados para análise, assim como os parâmetros usados para alguma das análises desenvolvidas.

- Manuscrito intitulado "Petrografia e geoquímica das formações ferríferas e rochas clásticas do Grupo Jacadigo, Neoproterozoico do sul da Faixa Paraguai”, que apresenta os resultados de estudos desenvolvidos na dissertação sobre as rochas do Grupo Jacadigo. 
- Síntese conclusiva e sugestões para pesquisas futuras

- Anexos com resumo sobre novas informações estratigráficas do Grupo Jacadigo, apresentado durante o XIV Simpósio de Geologia do Centro-Oeste (Anexo A) e artigo sobre os aspectos estruturais e tectônicos da região de Corumbá publicado no jornal Tectonophysics, em que o autor da presente dissertação participou como coautor (Anexo B).

As figuras e tabelas utilizadas no manuscrito seguem numeração corrida junto às figuras da dissertação.

\subsection{Objetivos}

O objetivo deste trabalho é contribuir com novas informações sobre as rochas do Grupo Jacadigo na localidade da Morraria Grande, sul da Faixa Paraguai.

A estratigrafia e petrologia dessas rochas são estudadas visando adicionar informações ao modelo geológico/deposicional das rochas do Grupo Jacadigo. O mapeamento e análise de testemunhos de sondagem na Morraria Grande são realizados com intuito de delimitar e caracterizar as rochas sedimentares do grupo. A petrografia, química mineral e geoquímica de amostras de formações ferríferas e rochas clásticas são utilizados para estudar os aspectos deposicionais e evolutivos destas rochas.

Os objetivos específicos desta dissertação são:

- Analisar a estratigrafia do Grupo Jacadigo por meio da descrição de testemunhos de furos de sondagem da Morraria Grande. Estabelecer e reavaliar as relações entre as unidades que formam o grupo e o seu embasamento na região.

- Analisar a petrografia e a geoquímica de amostras de testemunhos para investigar a origem e os processos que afetaram as formações ferríferas e sedimentos do Grupo Jacadigo ao longo da sua história evolutiva.

- Contribuir para a cartográfica geológica da região com o uso de novos dados de mapeamento da Morraria Grande e do mapeamento regional, dando, assim, continuidade a estudos cartográficos anteriores.

\subsection{Justificativa}

Muitos trabalhos tiveram como objetivo o estudo das morrarias à sudeste de Corumbá. No entanto, técnicas modernas de análise geoquímica e novos entendimentos sobre a geologia 
e as condições ambientais do Neoproterozoico, criaram possibilidades para que novas informações fossem adicionadas ao modelo geológico da região. Até então, os estudos geoquímicos e petrográficos foram restritos e focados nas rochas e camadas de manganês da Morraria do Urucum (Urban et al., 1992; Klein \& Ladeira, 2004; Piacentini et al., 2013). Por isso, dados estratigráficos e geoquímicos das rochas do grupo nas outras morrarias ainda são fundamentais para o entendimento das características da bacia neoproterozoica da região. $\mathrm{O}$ presente trabalho vem suprir, em parte, os dados petrológicos e estratigráficos do Grupo Jacadigo por meio de informações coletadas na Morraria Grande.

A área foi selecionada para o estudo por ter sido objeto de campanha de pesquisa mineral que resultou em grande quantidade de dados novos sobre o Grupo Jacadigo. O presente autor teve a oportunidade de participar da campanha durante o período de 2012-2013, ajudando no mapeamento, análise dos testemunhos de sondagem e modelagem do depósito. A parceria Vetorial Mineração - UnB possibilitou o acesso à área da mina e à testemunhos de sondagem do depósito de Santa Cruz. Tal parceria e acesso a dados representam justificativa importante para a realização deste trabalho, uma vez que o acesso a estas informações de detalhe não esteve disponível anteriormente nesta localidade.

\subsection{Localização e acesso}

A área em estudo corresponde às morrarias que se destacam nas vizinhanças de Corumbá, porção noroeste de Mato Grosso do Sul e proximidades da fronteira com a Bolívia. As morrarias se estendem de sudeste de Corumbá até depósitos a sudoeste, na Bolívia, e ficam distantes aproximadamente $51 \mathrm{~km}$ do centro de Corumbá.

O acesso às morrarias pode ser feito pela BR-262 (Fig. 1), partindo de Corumbá, até as entradas de estradas de terra mantidas pelas mineradoras que exploram ferro e manganês na região. Partindo da capital Campo Grande, o acesso às morrarias também é feito pela BR-262, passando por Aquidauana e Miranda, em trajeto que totaliza $387 \mathrm{~km}$ de asfalto até a rotatória que dá acesso às estradas de terra para as morrarias e às sedes das empresas de mineração que atuam na região. Corumbá dispõe de voos frequentes, assim como de várias linhas de ônibus diárias que a ligam a Campo Grande.

Os depósitos próximos à fronteira não foram abordados neste trabalho por representarem áreas de difícil acesso, por motivos de segurança e pela necessidade de autorizações das autoridades de fronteira dos dois países para trânsito nessas localidades. No 
entanto, os trabalhos que abordam esses depósitos foram citados na geologia regional e nas discussões para efeito de correlação e contextualização regional das rochas estudadas.

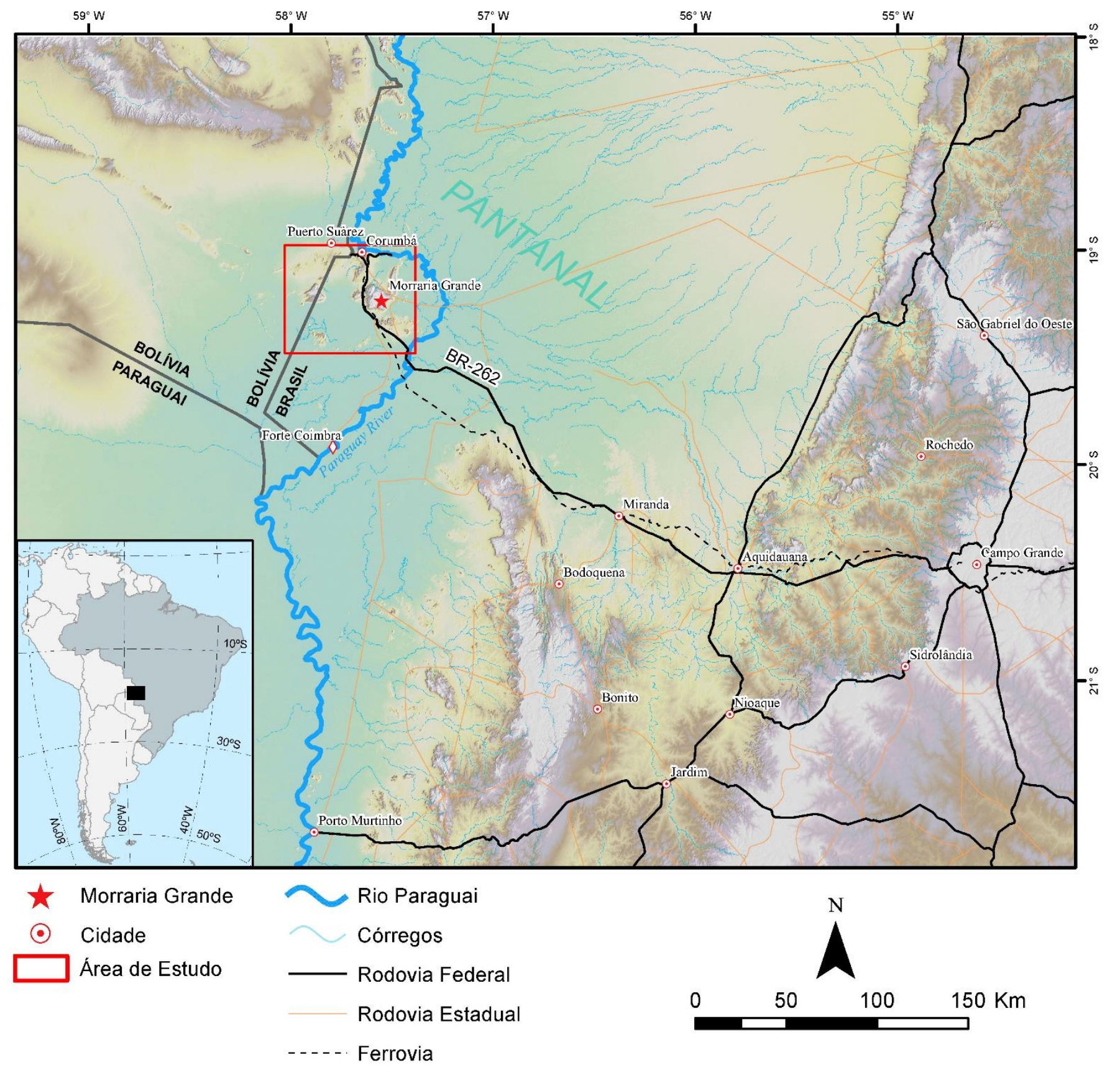

Figura 1 - Mapa de localização da área de estudo e principais vias de acesso (relevo sombreado gerado a partir do SRTM). 


\section{Contexto Geológico}

\subsection{Formações Ferríferas no Neoproterozoico}

Após hiato de mais de um bilhão de anos, o reaparecimento de formações ferríferas no Neoproterozoico representou grande desafio aos modelos anteriormente propostos de formação de IFs (Iron Formations) do Arqueano e do Paleoproterozoico. As formações ferríferas são rochas sedimentares químicas compostas por ferro e sílica, que se apresentam na forma de bandas ricas em óxido de ferro e bandas ricas em sílica amorfa ou criptocristalina, que recebem o nome de jaspe ou cherte. O termo formação ferrífera (iron formation - IF) evoluiu de "ironbearing formation", utilizado primeiramente para descrição das rochas encontradas na região do Lago Superior. O nome é sinônimo para os termos localmente utilizados em diversas partes do mundo, como itabirito (Brasil), jaspilito (Austrália), quartzito hematítico bandado (Índia) e ironstone bandado (África do Sul) (James, 1954).

Os depósitos mais significativos de formações ferríferas são encontrados majoritariamente no Pré-Cambriano, período no qual tiveram ampla distribuição na Terra. As formações ferríferas são descritas associadas a diversos ambientes e condições no passado geológico. Inicialmente os depósitos foram divididos em depósitos tipo Algoma, formados em ambiente de greenstone belts, e tipo Lago Superior, formado em ambiente plataformal (Gross, 1980). Posteriormente, depósitos do Neoproterozoico foram encontrados em meio a sequências glaciais, e são comumente classificados como depósitos do tipo Rapitan (Cox et al., 2013; Hagemann et al., 2015).

As eras Neoarqueano, Paleoproterozoico e Neoproterozoico compreendem os principais intervalos de tempo em que houve a geração de depósitos de formações ferríferas. As formações ferríferas formadas durante o Paleoproterozoico e o Neoarqueano foram responsáveis por gerar os maiores depósitos de ferro encontrados até hoje, superando em larga escala os depósitos formados no Neoproterozoico (Fig. 2) (Cox et al., 2013). No intervalo que ocorreu do fim do Paleoproterozoico até o início do Neoproterozoico, período denominado de boring billion (1.8 - $0.8 \mathrm{Ga}$ ), quase nenhum novo depósito foi formado (Holland, 2006).

O apogeu das formações ferríferas é normalmente atribuído ao Grande Evento de Oxigenação (GOE) que foi responsável por aumentar os níveis de oxigênio na atmosfera da Terra (2.4 - $2.0 \mathrm{Ga}$ ). $\mathrm{O}$ aumento dos níveis de oxigênio na atmosfera possibilitou que o ferro $\mathrm{Fe}(\mathrm{II})$, dissolvido nos oceanos e em mares restritos, fosse oxidado a $\mathrm{Fe}(\mathrm{III})$ e precipitado na 
forma de oxi-hidróxido de ferro $(\mathrm{FeOOH})$ para formar IFs (Iron Formations). As teorias para deposição de ferro levam em conta dois caminhos que têm como resultado o oxi-hidróxido de ferro insolúvel, um caminho de deposição biológica do ferro e outro de deposição abiótica deste elemento.

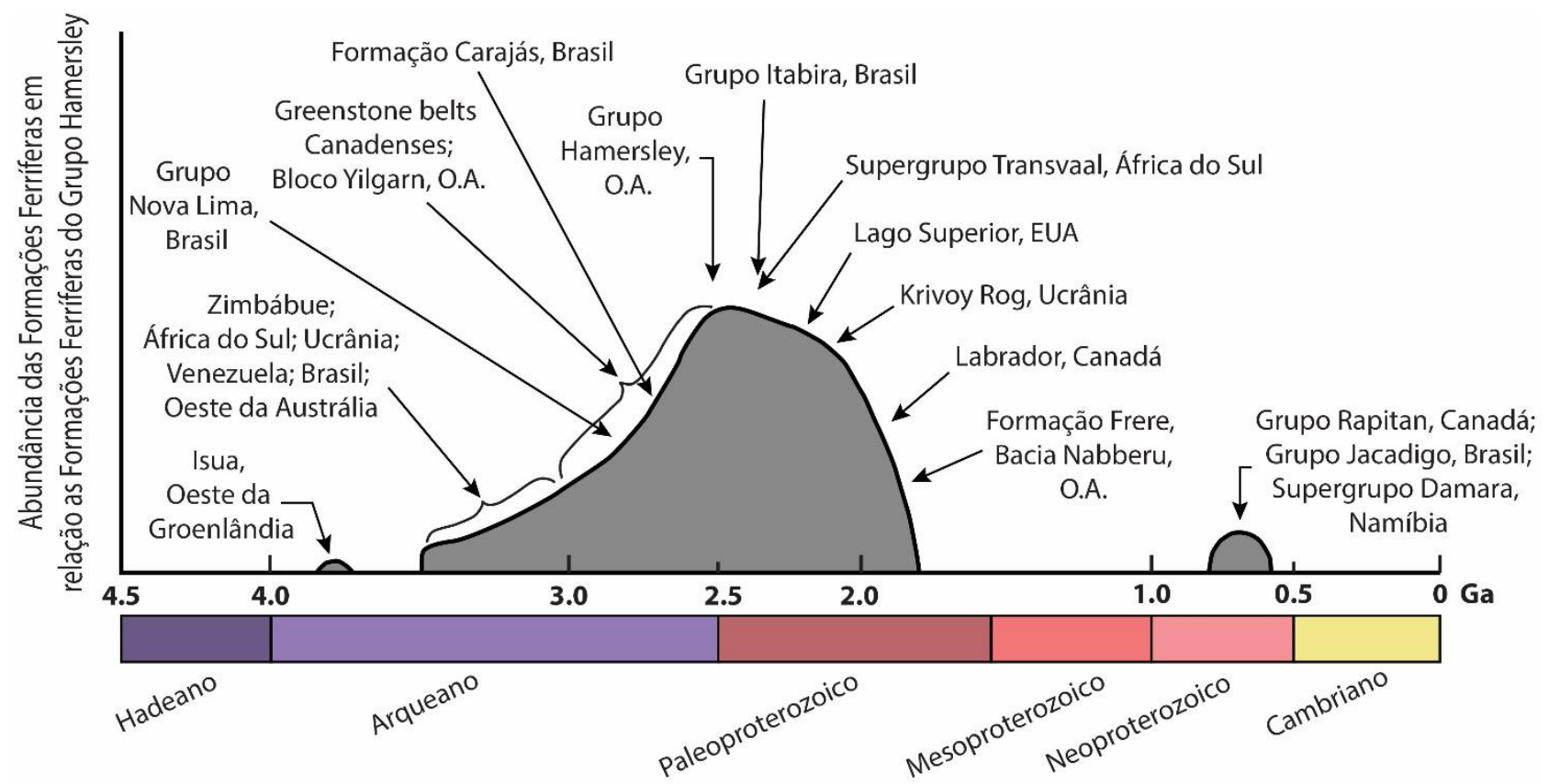

Figura 2 - Abundância e exemplo de formações ferríferas distribuídas segundo o tempo geológico (modificado de Klein, 2005).

O extenso período de ausência de deposição de IFs no Mesoproterozoico levantou a possibilidade de que os oceanos tivessem mantido ou voltado a ter condições euxínicas mesmo após o Grande Evento de Oxigenação (GOE). Segundo o modelo de Canfield (1998), condições sulfurosas prevaleceram durante essa era o que inibiu a deposição de formações ferríferas, até que um novo evento de oxigenação no Neoproterozoico ocorresse. Este modelo para o oceano recebeu o nome de "Oceano Canfield".

Trabalhos posteriores mostraram que o suposto oceano empobrecido em oxigênio no Mesoproterozoico nunca realmente existiu, e que condições euxínicas eram restritas e localizadas. O oceano presente durante o boring billion apresentava-se estratificado, mostrando condições de oxigenação intermediária em níveis rasos, e porções mais profundas pouco oxigenadas (Holland, 2006). Tal argumento é baseado nas baixas taxas de deposição de matéria orgânica e também na ausência de depósitos de fosforitos nesse intervalo de tempo.

As IFs neoproterozoicas, no entanto, apresentam características peculiares que os diferem das IFs arqueanas e paleoproterozoicas. Sua íntima relação com ambientes e eventos glacias e as novas condições atmosféricas predominantes durante o Neoproterozoico 
(Kirschvink, 1992) criaram assinaturas específicas para esse tipo de depósito e novos modelos genéticos tem tentado explicar a volta da deposição dessas rochas, assim como as condições em que foram formadas.

Uma característica marcante nas formações ferríferas neoproterozoicas, que as difere das rochas mais antigas, é sua mineralogia. Nas rochas neoproterozoicas hematita se apresenta como principal mineral de ferro, enquanto magnetita está associada a porções localizadas ou como resultado de processos metamórficos (Klein \& Beukes, 1993; Cox et al., 2013). Em alguns depósitos foram descritos minerais como criptomelano (óxido de manganês), que formam camadas e lentes finas em meio a sequências de formações ferríferas (Dorr II, 1945; Urban et al., 1992; Piacentini et al., 2013).

A análise geoquímica das formações ferríferas neoproterozoicas difere em grande parte da geoquímica das formações ferríferas mais antigas por estarem associadas com eventos glaciais e uma atmosfera já com oxigênio. A comum contribuição de sedimentos glacias em meio as sequências de formações ferríferas no neoproterozoico muitas vezes é responsável pelo enriquecimento geral nos padrões de elementos terras raras em fácies dessas rochas (Cox et al., 2013). Anomalias positivas de Eu, normalmente associadas a contribuição hidrotermal, estão ausentes ou muito suavizadas nas formações ferríferas neoproterozoicas (Khalil et al., 2015), em contraste com a forte anomalia positiva desse elemento nos equivalentes do Arqueano e Paleoproterozoico.

As formações ferríferas neoproterozoicas (NIFs) em sua grande maioria estão relacionadas a sedimentos glaciais, como os que serão descritos a seguir. No Neoproterozoico, a grande maioria das formações ferríferas é atribuída à glaciação Sturtiana ( 700 Ma), que tem como principal exemplo as formações ferríferas do Grupo Rapitan no Canadá (Hoffman \& Schrag, 2002). Outros exemplos de formação ferrífera associada a sedimentos glaciais no Neoproterozoico são as rochas pertencentes à Formação Santa Cruz do Grupo Jacadigo no Brasil (Dorr II, 1945; Urban et al., 1992), atribuídas à glaciação Marinoana por datações indiretas (Trompette et al., 1998) e os metadiamictitos ferruginosos da Formação Nova Aurora do Grupo Macaúbas de idade Sturtiana (Vilela, 2010). Dentre os exemplos de formações ferríferas do Neoproterozoico, há relatos de depósitos menores dessas rochas em associação com rochas vulcânicas, como as da Formação Jucurutu da Faixa Seridó, no NE do Brasil (Sial et al., 2015) e do depósito de Gebel El Hadid no Egito (Khalil et al., 2015) e também relatos de 
formações ferríferas associadas a ambientes plataformais, como as formações ferríferas do Grupo Shilu na China (Xu et al., 2013).

\subsection{Glaciações e depósitos glaciais}

Durante o Neoproterozoico houveram grandes mudanças na atmosfera (Holland, 2006), aliadas a grande concentração de massas continentais nas proximidades do paleoequador. $\mathrm{O}$ posicionamento da crosta continental na porção central da Terra foi, então, responsável por gerar efeito intenso de albedo, capaz de iniciar eventos glaciais, dando origem a teoria do "Snow Ball Earth” (Kirschvink, 1992). Os eventos tiveram início há cerca de 850 Ma e deixaram registros na forma de depósitos glaciais em diversas regiões do mundo. Tais eventos estão marcados por meio de dados de $\delta^{13} \mathrm{C}$ (Hoffman, 1998, 2002) que mostram digressão concordante com os eventos glaciais, seguida de posterior aumento, marcando o fim desses eventos e o aparecimento de carbonatos de capa em vários locais.

As glaciações neoproterozoicas foram divididas em três grandes eventos de ocorrência dispersa ao redor do mundo, denominados de glaciação Sturtiana (726-660 Ma), glaciação Marinoana (655-635 Ma) e glaciação Gaskiers/Ediacarana ( 582 Ma) (Hoffman et al., 1998; Hoffman \& Schrag, 2002; Hoffman \& Li, 2009). Apesar das idades diferentes para cada intervalo, grande parte dos valores obtidos para os depósitos associados a essas glaciações consiste em datações indiretas, em que são datadas rochas dos limites superiores e inferiores, muitas vezes abrangendo intervalos muito extensos de idades para as glaciações, principalmente para a glaciação Sturtiana (Babinski, 2011).

Em períodos glaciais a sedimentação se dá principalmente pela ação de geleiras que representam agentes erosivos poderosos e com grande capacidade de gerar acumulação de sedimentos, tanto no continente como no oceano. Os depósitos glaciais continentais são raramente preservados devido à exposição na superfície e fácil erosão. No entanto, os depósitos formados em ambientes marinhos ou lacustres, os sedimentos glaciais podem ser armazenados na bacia, onde ficam isolados dos processos erosivos superficiais e são mais facilmente preservados no registro geológico.

Os sedimentos glaciais depositados em ambientes marinhos ou subaquosos têm sua sedimentação fortemente influenciada ou controlada pela dinâmica das geleiras proximais e pelos processos marinhos atuantes na bacia. O recuo de geleiras nas proximidades do corpo d'água, por exemplo, pode causar a rápida sedimentação de sequências transgressivas. Nesse 
processo os sedimentos podem ser posteriormente retrabalhados por correntes e marés no ambiente marinho (Eyles e Eyles, 2010). Registros de sedimentos glaciais em águas profundas também podem ser formados durante o avanço das geleiras proximais sobre o mar ou lago, resultando também no recuo das margens destes corpos d'água.

Os principais depósitos gerados em ambientes glaciais são em geral caracterizados por sedimentos mal selecionados compostos de mistura de cascalho e blocos em matriz arenoargilosa em proporções variáveis. O termo tilito é aplicado a este tipo de material quando há evidências suficientes que demonstrem a deposição ou origem dos sedimentos por meio de processos glaciais. Caso não haja informações unânimes de processos glaciais, o termo diamictito é empregado para descrever a formação de depósitos de sedimentos mal selecionados suportados por matriz argilosa ou arenosa, independentemente de sua origem (Eyles e Eyles, 2010).

Regiões que passaram por glaciações no passado ou foram afetadas pela presença de capas de gelo apresentam indícios e estruturas marcantes destes eventos em suas rochas e afloramentos. Os registros comumente observados em depósitos glaciais são pavimentos estriados, que resultam da movimentação de massas de gelo sobre o assoalho rochoso, arrancando fragmentos e gerando ranhuras no assoalho em regiões continentais. Em ambiente marinho, uma característica comum dos depósitos glaciais é a presença de seixos pingados (dropstones) de material alóctono em meio às camadas de sedimentos mais finos na sequência. Em depósitos próximos a geleiras seixos são carregados junto à base da geleira e se desprendem da massa de gelo ao chegar em ambiente marinho ou lacustre e são depositados em ambientes subaquosos mais profundos em meio a sequências diferentes.

As formações ferríferas do Neoproterozoico estão em sua grande maioria depositadas em meio a sequências de diamictitos interpretados como glaciais. O exemplo mais bem conhecido deste tipo de depósito são as formações ferríferas do Grupo Rapitan, no Canadá (Baldwin, 2014). Os trabalhos sobre esse depósito têm contribuído diretamente para o entendimento dos processos que levaram à sua formação da, também, têm servido de modelo para outras formações ferríferas neoproterozoicas no mundo, ajudando na formulação de teorias para gênese dos depósitos e com informações sobre as condições na superfície do planeta nessa era. 


\subsection{Formações Ferríferas do Grupo Rapitan}

As formações ferríferas do Grupo Rapitan ocorrem na região das Montanhas Mackenzie, noroeste do Canadá (Fig. 3). As rochas sedimentares químicas e sedimentos de influência glacial formam extensos depósitos que afloram em Redstone River (sudeste das Montanhas Mackenzie) e Snake River (noroeste das Montanhas Mackenzie) (Young, 1976).

O Grupo Rapitan está inserido no Supergrupo Windermere (Fig. 4), que é composto também pelos grupos Coates Lake e Hay Creek. O Supergrupo Windermere inicia com as rochas do Grupo Coates Lake, que consistem de sequências de rift continental. Acima do Grupo Coates Lake, e depositadas sobre uma inconformidade, as rochas do Grupo Rapitan são relacionadas a ambientes glaciais e compreendem diamictitos e sequências turbidíticas com camadas de formações ferríferas. Sobreposto ao Grupo Rapitan, está o Grupo Hay Creek que é formado por siltitos, grauvacas, calcários, diamictitos e carbonatos de capa, que encerram a seção.

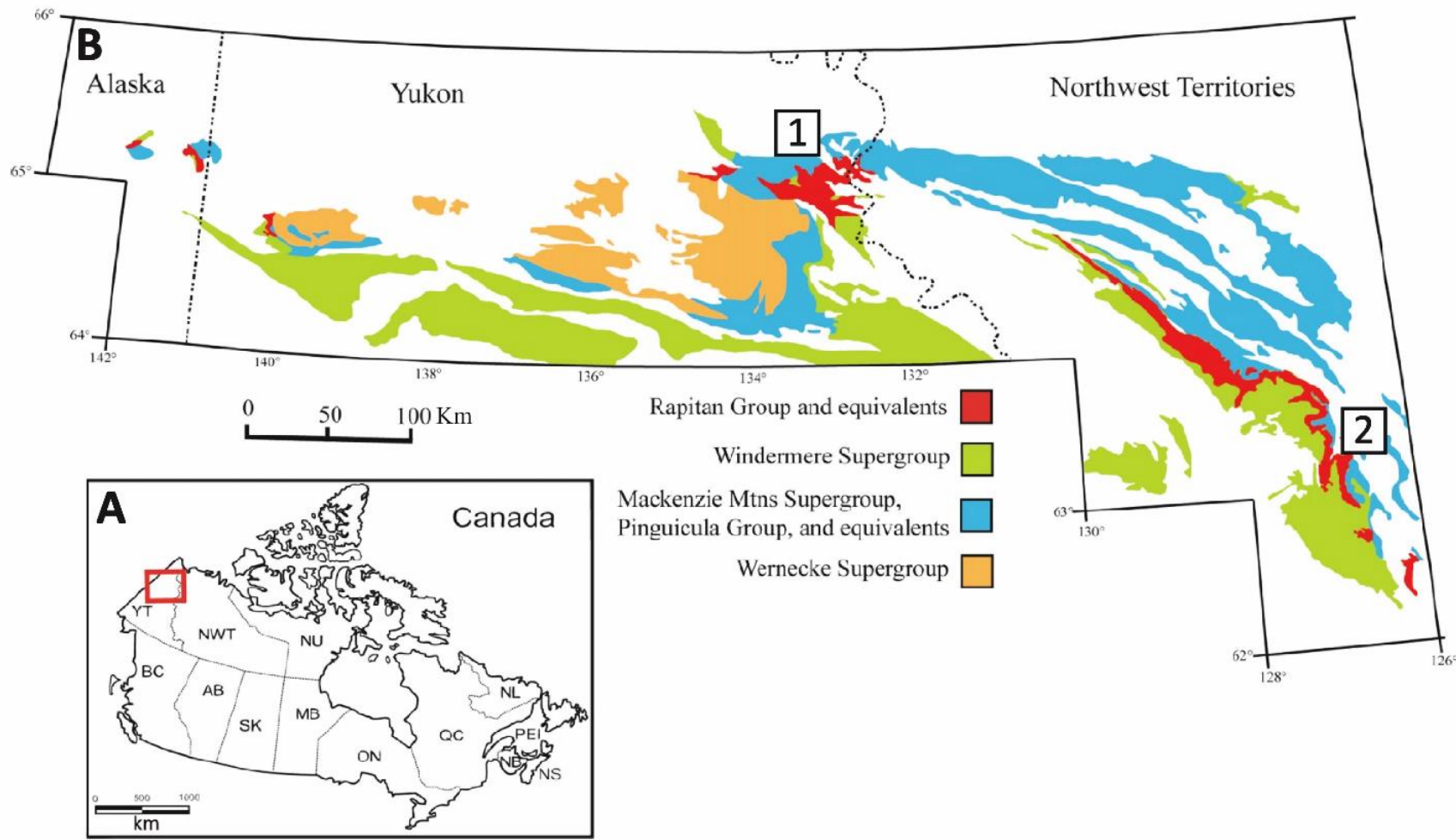

Figura 3 - (A) Mapa de localização e (B) mapa geológico com as ocorrências do Supergrupo Windermere e as rochas do Grupo Rapitan, (1) Snake River, (2) Redstone River (Baldwin et al., 2012).

O Grupo Coates Lake tem sua ocorrência restrita à região de Redstone River (Young, 1976; Klein \& Beukes, 1993). O grupo é constituído pelo basalto Little Dal, e pelas formações Thundercloud, Redstone River e Coppercap. Os grupos Coates Lake e Rapitan são interpretados 
como associados aos eventos de rifteamento ocorridos durante fragmentação de Rodínia no Proterozoico Superior (Klein \& Beukes, 1993).

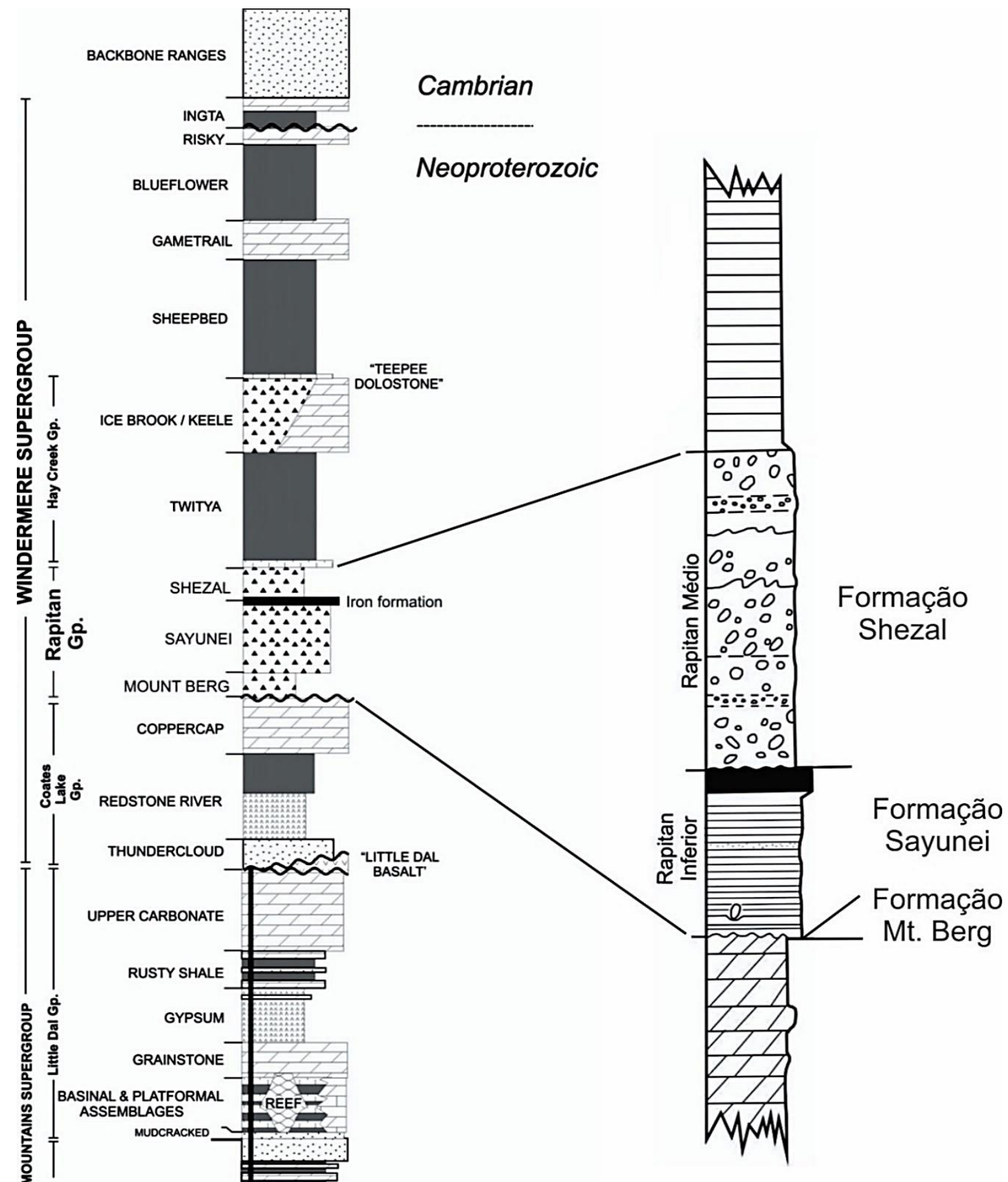

Figura 4 - Coluna estratigráfica da região das Montanhas Mackenzie e destaque para o Grupo Rapitan (Young, 1976; Baldwin et al., 2012). 
O Grupo Rapitan é dividido em três formações, Mt. Berg que consiste em diamictitos (mixtitos) (Young, 1976) de ocorrência restrita, Sayunei, composta de sequências turbidíticas de coloração escura, associadas a depósitos de águas profundas e capeadas por camadas de formação ferrífera jaspilítica, e Shezal, formada por espessos pacotes de diamictitos de coloração verde, cinza ou castanha, contendo clastos de formações ferríferas na base (Cox et al., 2013).

As formações ferríferas da Formação Sayunei apresentam espessuras menores na região de Redstone River em comparação com as ocorrências de Snake River, nas Montanhas Wernecke, onde são extensivamente explotadas (Klein \& Beukes, 1993; Baldwin, 2012). Na região de Snake River o Grupo Coates Lake e a Formação Mt. Berg, porção basal do Grupo Rapitan, não estão presentes, e as rochas das formações superiores se depositaram diretamente sobre as sequências do Supergrupo Mackenzie Mountains (Young, 1976; Klein \& Beukes, 1993).

As rochas que ocorrem logo abaixo dos IFs na região de Snake River são compostas por conglomerados polimíticos suportados por clastos de material retrabalhado de unidades do Supergrupo Mackenzie Mountains (Baldwin et al., 2012). O material apresenta clastos de carbonato, arenito e basalto, com cimento carbonático e grãos de quartzo preenchendo os poros do material.

O Grupo Hay Creek, que recobre o Grupo Rapitan, é formado pelas formações Twitya, Keele e Ice Brook, assim como pelo dolomito Teepee. A Formação Twitya é composta de rochas clásticas terrígenas, que estão recobertas pelos carbonatos e arenitos intercalados da Formação Keele (James et al., 2001). Acima está depositada a Formação Ice Brook com extensos diamictitos com clastos de carbonatos. As formações Keele e Ice Brook são capeadas por extensa capa de carbonatos dolomíticos, denominados “Teepee Dolostones" (James et al., 2001).

Ziegler (1959) foi o primeiro a propor origem glacial para os conglomerados do Grupo Rapitan na região de Snake River. Posteriormente, Young (1976) realizou trabalho em que apresentou registros de depósitos glaciais na sequência, como a presença de clastos facetados e estriados, fragmentos de materiais exóticos e seixos pingados na localidade de Redstone River. Young (1976) propôs para o Grupo Rapitan modelo de bacia proximal a uma geleira e 
condicionada aos seus regimes de avanço e recuo. A sequência teria início com a deposição controlada por geleira de base molhada, que transicionaria para uma sequência associada a uma geleira de base seca.

Klein \& Beukes (1993), em estudo de testemunhos da região de Snake River, propuseram ambiente glácio-marinho para o grupo, tendo como argumento a extensa área em que as rochas eram encontradas. Os mesmos autores sugerem ainda que as formações ferríferas foram depositadas em águas limpas, o que é evidenciado pela falta de contaminação de argila e devido aos contatos abruptos com as rochas encaixantes.

Durante extenso período não foi possível obter idades confiáveis para o Grupo Rapitan. No entanto, Macdonald et al. (2010) conseguiram obter idades U-Pb mais confiáveis, datando tufos depositados em meio à unidade correlata ao Grupo Rapitan, que apresentaram idade de $716 \pm 10$ Ma. Os sedimentos vulcânicos chamam a atenção para os processos vulcânicos que estavam em atividade durante a deposição das formações ferríferas, dados que dão suporte para a relação genética entre processos do manto e a deposição das formações ferríferas (Bekker et $a l ., 2010)$.

\subsection{Tectônica do Neoproterozoico}

A preservação das formações ferríferas durante a história geológica está atrelada a preservação de sequência de rochas sedimentares de mar profundo frente a processos tectônicos que consomem a crosta oceânica em zonas de subducção (Lascelles, 2013). A fragmentação do supercontinente Rodínia no Neoproterozoico $(700$ - 750 Ma) foi um extenso processo tectônico que gerou mudanças na superfície terrestre, assim como na atmosfera e nos oceanos existentes (Hoffman, 1991). Reconstruções paleogeográficas baseadas em dados isotópicos e estudos de paleomagnetismo mostram que a ruptura do supercontinente foi responsável por gerar grande movimentação e rearranjo de blocos durante esse período.

No final do Mesoproterozoico, e com a estabilização do Supercontinente Rodínia, a Terra apresentava uma configuração de blocos continentais dispostos em volta de Laurentia (Fig. 5), que perdurou até $750 \mathrm{Ma}$. Após $750 \mathrm{Ma}$, e com o início da ruptura, observa-se a organização e formação de nova configuração, com os blocos se posicionando em torno do Congo, enquanto Laurentia e Báltica são isolados com a formação do Oceano Iapetus.

Como alternativa para o modelo de ruptura do Rodínia, Cordani et al. (2003) sugerem que a fragmentação do supercontinente teria se iniciado com a formação de riftes, 
diacronicamente ao final da Orogenia Grenvilliana $(\sim 1 \mathrm{Ga})$ ou logo após sua estabilização. Os riftes levaram à ruptura do supercontinente e separação de blocos continentais por bacias

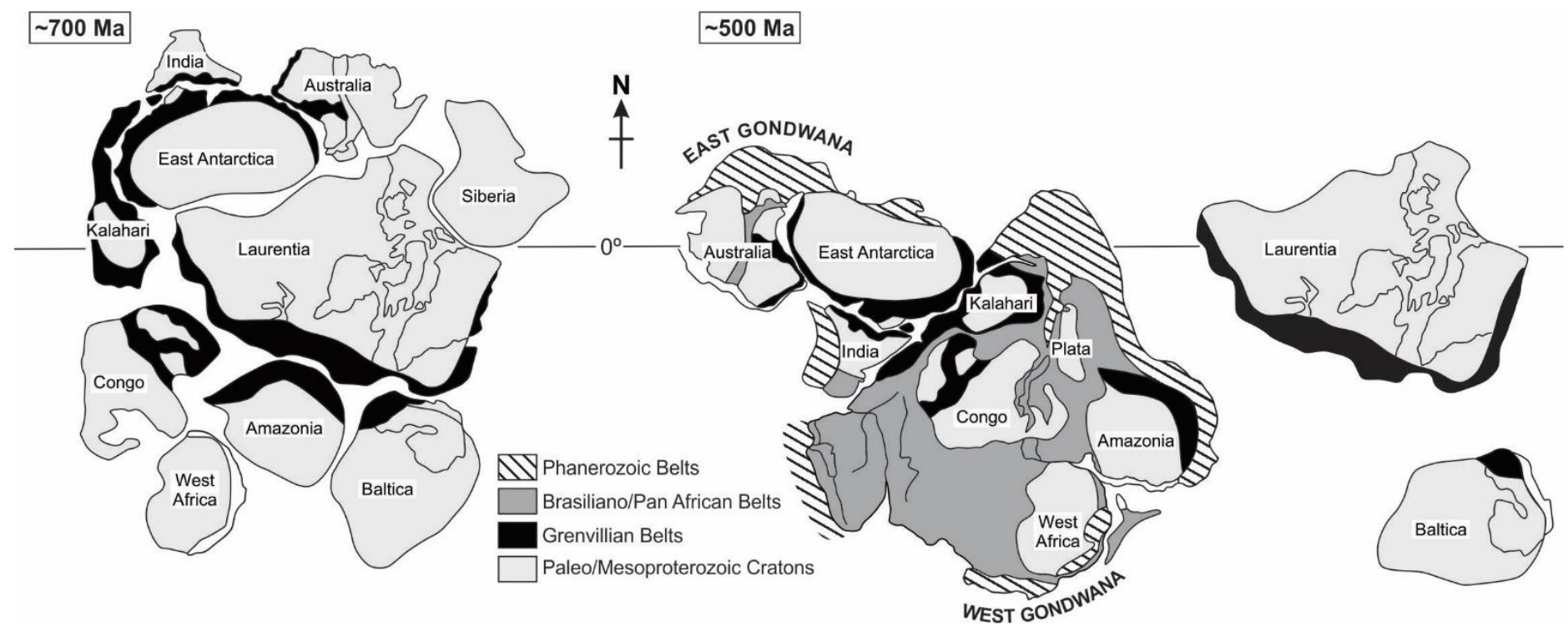

Figura 5 - Representação paleogeográfica de continentes no Neoproterozoico (Hoffman, 1991).

oceânicas, subsequentemente destruídas, culminando em cinturões colisionais formados na Orogenia Brasiliana/Pan-Africana. Os eventos colisionais estão relacionados com o desaparecimento de crostas oceânicas e são marcados pela presença de extensos arcos magmáticos com assinatura isotópica derivada de crosta oceânica juvenil.

As mudanças na configuração dos blocos continentais do fim do Mesoproterozoico e início do Neoproterozoico não ocorreram de forma linear. Os eventos de separação são referidos como diacrônicos aos eventos iniciais de colisão para a formação do Supercontinente Gondwana. Este fato resultou em dualismo extensional e compressional que perdurou durante todo o Neoproterozoico (Cordani et al., 2003; Li et al., 2008; Fuck et al., 2008).

No contexto da América do Sul, após a fragmentação de Rodínia, grande quantidade de blocos colidiu para formar o novo supercontinente. Os maiores blocos que tiveram participação nestes eventos colisionais foram os crátons Amazônico, São Francisco (-Congo) e Rio de la Plata. Os blocos menores, assim como os blocos não aflorantes abaixo das bacias sedimentares, tiveram importante participação nos eventos colisionais do Neoproterozoico (Fuck et al., 2008), apesar de muitas vezes esquecidos nas reconstruções paleogeográficas.

A área estudada está localizada na região entre três blocos geotectônicos, o Bloco Rio Apa, composto por rochas metamórficas de médio grau e de idade paleo-mesoproterozoica, o Cráton Amazônico, terreno estabilizado ao final do Mesoproterozoico e que serviu como bloco 
estável durante toda a deformação que ocorreu posteriormente, e o Bloco Paranapanema, encoberto pela Bacia do Paraná e definido pela interpretação de dados geológicos e geofísicos (Cordani et al., 1984; Mantovani et al., 2005; Mantovani e Brito Neves, 2010) e de modelos tectônicos que explicam as deformações na borda dos crátons aflorantes e de conhecimento.

As rochas sedimentares expostas na região de Corumbá (MS) se encontram próximas à junção entre o aulacógeno Chiquitos-Tucavaca e a faixa de dobramentos Paraguai, estruturas que registram aspectos de uma bacia rifte e da amalgação do Gondwana Oeste durante o ciclo orogênico Brasiliano, respectivamente (D’el-Rey Silva el at., 2016). Os aspectos tectônicos da região sugerem a ocorrência de uma junção tríplice, em que Corumbá estaria posicionada próximo ao seu centro (Jones, 1985). As rochas da região estão distribuídas formando um graben, que foi denominado de graben de Corumbá (Trompette et al., 1998).

\subsection{Geologia Regional}

As formações ferríferas do Grupo Jacadigo estão inseridas no contexto da Faixa Paraguai e se prolongam para a Bolívia onde pertencem ao Grupo Boqui. A Faixa Paraguai corresponde a um cinturão de dobramentos neoproterozoico, formado por rochas sedimentares e metassedimentares depositadas a sudeste do Cráton Amazônico e a leste do Bloco Rio Apa. A sequência de rochas que compõem a faixa foi dividida estruturalmente em coberturas cratônicas plataformais e zonas interna e externa da faixa (Fig. 6). As coberturas plataformais localizadas sobre a margem cratônica do Bloco Rio Apa e do Cráton Amazônico se destacam pela baixa deformação e ausência de metamorfismo, enquanto as rochas que constituem as zonas externa e interna da faixa mostram deformação e metamorfismo progressivo de oeste para leste (Almeida, 1984; Alvarenga \& Trompette, 1993; Alvarenga et al., 2000).

A Faixa Paraguai foi formada durante a Orogenia Brasiliana e se estende por quase 1500 km, constituindo um arco que bordeja o Cráton Amazônico e o Bloco Rio Apa (Almeida, 1984). A faixa está exposta em duas porções: a setentrional, que acompanha a margem sudeste do Cráton Amazônico e a meridional, composta pela Serra da Bodoquena e as morrarias do Urucum que margeiam o Bloco Rio Apa. As duas porções são separadas pelas unidades sedimentares que formam as bacias do Pantanal e do Paraná e que recobrem a maior parte da zona interna e parte da zona externa da faixa (Campanha et al., 2011).

As divisões estratigráficas para as unidades que compõem a Faixa Paraguai e as coberturas cratônicas adjacentes são objeto de pouco consenso em relação aos seus limites e 
nomenclatura. Nomes, costumeiramente aplicados para as unidades da porção setentrional diferem dos nomes aplicados às unidades da porção meridional, e da mesma forma ocorre com as unidades localizadas nos vizinhos Bolívia e Paraguai. Em face disso, optou-se pela classificação, de caráter mais abrangente, proposta por Alvarenga et al. (2000) e possível de ser aplicada na porção meridional. Segundo estes autores, as unidades litoestratigráficas que compõem a faixa e a cobertura cratônica se dividem em unidades inferior, de natureza turbidítica-glaciogênica, média, de natureza carbonatada, e superior, de natureza siliciclástica. As variações destas fácies ocorrem lateralmente. A oeste expõem-se depósitos glácio-marinhos de ambiente plataformal que passam, a leste, para sedimentos que foram depositados em bacia mais profunda, com a presença de turbiditos (Alvarenga \& Saes, 1992).

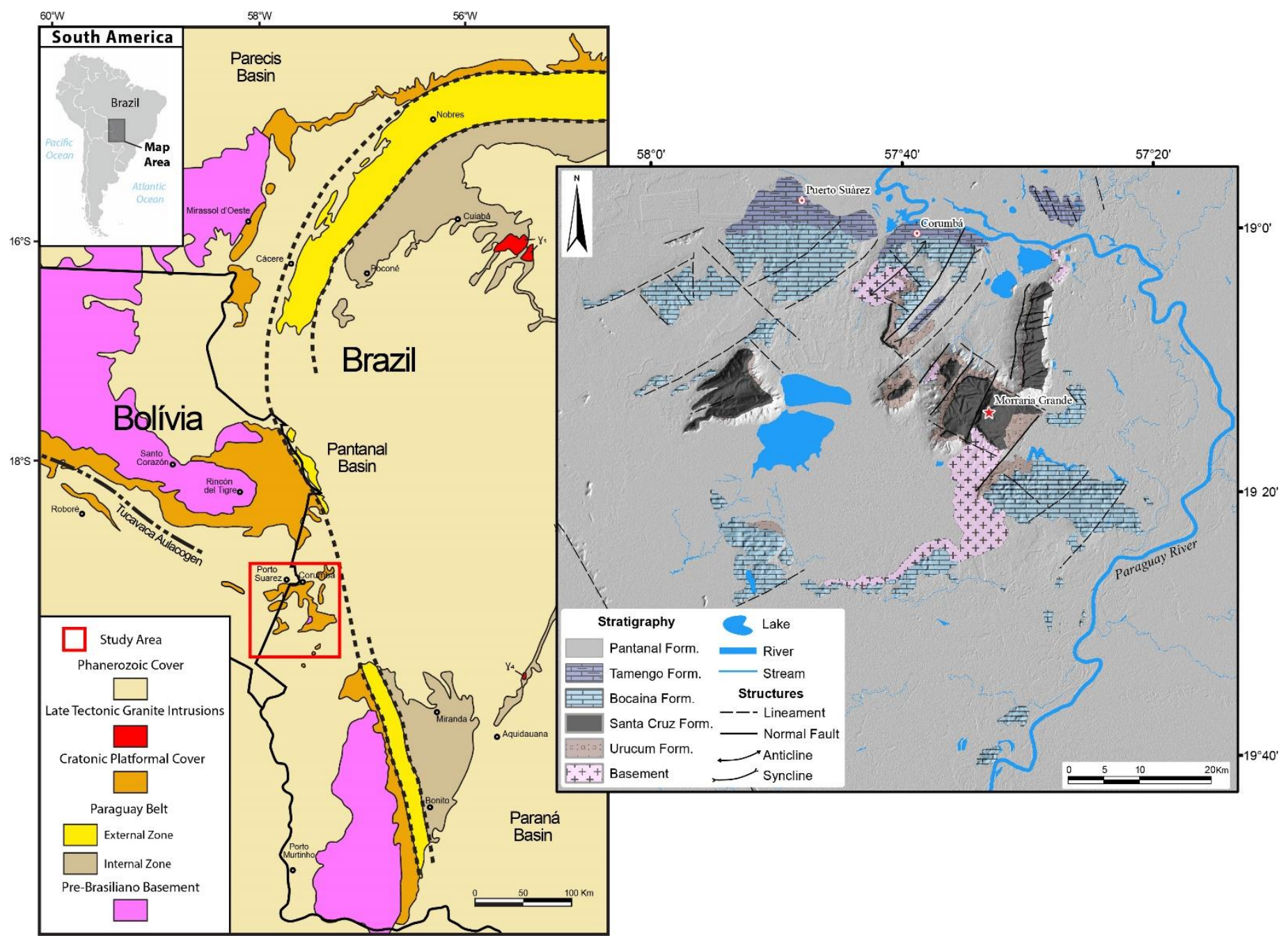

Figura 6 - Mapa da Faixa Paraguai (modificado de Alvarenga \& Trompette, 1993), retângulo vermelho marca área de estudo (esquerda) e mapa geológico da região de Corumbá (direita) (modificado de Weiss \& Sweet, 1959; Walde, 1988; Freitas et al., 2011). 
O primeiro relato dos aspectos geológicos da região de Corumbá foi feito por D’Orbigny em 1842 (apud Dorr II, 1945). Posteriormente J.W. Evans (1894) publicou trabalho em que relatava a estratigrafia da região de Corumbá, assim como de outras localidades no então Mato Grosso, descrevendo afloramentos e ocorrências de calcários e arcósios e os correlacionando estratigraficamente.

Lisboa, em 1909, em trabalho para a empresa de construção da ferrovia, descreveu em maior detalhe as rochas da região de Corumbá, definindo também o Grupo Jacadigo (Almeida, 1945). No entanto, somente em 1945 Almeida e Dorr executaram estudos estratigráficos de detalhe sobre as rochas que formam as morrarias na região, que ainda são referência.

Durante extenso período (1945-1980) quase nenhum trabalho foi publicado em periódicos científicos, exceto resumos em congressos nacionais e internacionais. A partir de 1980, novos trabalhos voltaram a ser publicados, como Walde et al. (1981) e Hoefs et al. (1987). Na década de noventa, com Urban et al. (1992), Graf et al. (1994) e Trompette et al. (1998), novos trabalhos se revestem de fundamental importância ao trazerem novos dados geoquímicos e geocronológicos que contribuíram para o entendimento da evolução geológica da área.

Nas últimas décadas diversos trabalhos foram publicados, focando em entender a gênese dos depósitos de ferro (Walde \& Hagemann, 2007), em que são relatados todos os modelos até então propostos para a área. Estudos petrográficos e geoquímicos em amostras selecionadas da morraria de Urucum também foram realizados (Klein \& Ladeira, 2004). Mais recentemente, trabalhos foram publicados com vistas a tentar esclarecer as dúvidas que ainda permanecem em relação a gênese, condições ambientais e idade dos depósitos, como Freitas et al. (2011), Piacentini et al. (2013), Angerer et al. (2016), Viehmann et al. (2016) e D'el-Rey Silva et al. (2016). 


\section{Materiais e Métodos}

Para as análises foram utilizadas, como material principal, amostras de testemunhos de sondagem diamantada obtidas por meio de parceria com a Vetorial Mineração Ltda, mineradora proprietária dos direitos de exploração na região da Morraria Grande. As amostras são resultado da campanha de sondagem exploratória que foi executada em 2012-2013. No presente trabalho foi aplicado 3 métodos de análise sobre os materiais disponibilizados:

i) Análises petrográficas em microscópio de luz transmitida e refletida

ii) Análises litogeoquímicas sobre amostras selecionadas de testemunhos de sondagem

iii) Análises de química mineral em microssonda eletrônica de minerais e estruturas selecionadas.

\subsection{Amostragem e preparação das amostras}

Para a amostragem representativa dos materiais foram escolhidos intervalos específicos dos testemunhos de sondagem, visando investigar camadas que apresentassem mudanças mineralógicas e/ou texturais e que pudessem contribuir para as informações sobre os fatores atuantes durante o processo de deposição e diagênese das rochas.

O material amostrado foi utilizado primeiramente para confecção de lâminas com o objetivo de análises petrográficas e de microssonda. As porções restantes das amostras foram pulverizadas para separação de minerais e para análises de raio-X.

\subsection{Petrografia}

As amostras selecionadas para análise petrográfica foram coletadas com a finalidade de observar variações mineralógicas e texturais em intervalos mais restritos e também para caracterizar intervalos mais representativos em diversas profundidades dos furos de sondagem investigados. A coleta foi feita por toda extensão dos testemunhos, visando mapear variações e alterações em níveis específicos da estratigrafia.

Para a análise petrográfica foi utilizado microscópio polarizador e com dupla iluminação (transmitida e incidente) da marca Olympus, modelo BX-41. As lâminas foram confeccionadas na Fundação Gorceix e no laboratório de laminação do Instituto de Geociências da UnB. Os estudos sobre as lâminas foram conduzidos nos laboratórios de Microscopia e de Geocronologia 
da UnB. As lâminas também passaram por processo de metalização para as posteriores análises em microscópio eletrônico de varredura e microssonda eletrônica.

\subsection{Litogeoquímica por ICP-MS e ICP-ES}

Dentre as amostras disponibilizadas foram separadas 24 amostras de testemunhos pertencentes a 3 furos de sondagem para análise de elementos maiores e menores e de ETR+Y em ICP-ES (Inductively Coupled Plasma - Emission Spectrometry) e ICP-MS (Inductively Coupled Plasma-Mass Spectrometry) respectivamente. As amostras foram selecionadas tendo como alvo traçar variações composicionais que pudessem estar associadas à textura e também à profundidade da amostra coletada.

A preparação das amostras foi executada no moinho do laboratório de Geocronologia do Instituto de Geociências. O material foi primeiramente fragmentado, utilizando-se martelo ou britador, para obter a amostra nos padrões de granulometria necessários para análise e, posteriormente, foi pulverizado em moinho de panela. A panela utilizada para a moagem foi uma panela da marca Brastorno composta por liga metálica de alta dureza (vídia). As amostras foram enviadas para o Canadá para análise no Bureau Veritas Minerals Laboratories.

\subsection{Microscópio Eletrônico de Varredura (MEV) e Sistema de Energia Dispersiva (EDS)}

O microscópio eletrônico de varredura foi utilizado para obtenção de imagens de elétrons secundários (SE) e elétrons retroespalhados (BSE), e análises preliminares semiquantitativas das lâminas por meio do sistema de energia dispersiva (EDS). As análises semiquantitativas por sistema de energia dispersiva (EDS) tiveram a função de sanar dúvidas em relação à composição de fases minerais observadas inicialmente na petrografia. Os pontos e imagens obtidos deste instrumento serviram para orientação e visualização dos alvos a serem posteriormente analisados na microssonda. A ferramenta foi fundamental para a seleção e descarte de alvos de análises posteriores em microssonda eletrônica, e para a eficiência da análise nesse instrumento.

\subsection{Microssonda Eletrônica (MSE)}

A Microssonda Eletrônica (MSE) consiste em equipamento que realiza análises composicionais quantitativas e qualitativas pontuais por meio de sistema de dispersão por comprimento de onda (WDS) e pelo sistema de dispersão de energia (EDS). O mecanismo de análise da microssonda se assemelha à fluorescência de raios $\mathrm{X}$, exceto pela amostra ser 
excitada por um feixe de elétrons em lugar do feixe de raios $\mathrm{X}$ utilizado na fluorescência (Rollinson, 1993).

O sistema de dispersão por comprimento de onda (WDS) obtém os resultados pela análise do comprimento de onda de raios X secundários emitidos pela amostra quando esta é bombardeada por um feixe de elétrons em uma câmara a vácuo no interior do equipamento. $\mathrm{O}$ sistema de dispersão de energia (EDS) utiliza os valores de energia e intensidade do espectro. Após análise, os resultados são obtidos para cada ponto analisado com valores em porcentagem em peso de óxidos para o sistema de dispersão por comprimento de onda, e com auxílio de gráficos de intensidade da energia para o sistema de dispersão da energia.

A preparação das amostras para análise teve início com o polimento das lâminas petrográficas, o que permitiu obter superfície lisa e mais homogênea, ajudando também na eliminação de imperfeições ou impurezas que poderiam estar presentes na lâmina. Posteriormente foi executado o procedimento de metalização por grafite em câmara a vácuo. Durante a metalização é gerada fina camada de grafite na superfície da lâmina analisada, tornando-a condutora e permitindo receber e dissipar o feixe de elétrons de forma mais homogênea.

A análise de microssonda foi utilizada para caracterizações químicas pontuais quantitativas em pequena escala. As análises foram feitas para diferenciação de fases minerais e composição dos cristais, assim como substituições. Os alvos para análise foram primeiramente demarcados na petrografia, com ajuda de caneta e microscópio de luz refletida.

As análises foram conduzidas em grãos de minerais encontrados na porção clástica, nas bandas diferenciadas de cherte e de hematita, e em nódulos e veios encontrados. O principal objetivo foi comparar a composição das fases minerais nas diversas estruturas e texturas encontradas. Devido à metalização por grafita a análise de fases carbonáticas ficou comprometida, e para identificação composicional destas fases foram feitas análises de raio-X.

As análises de microssonda foram conduzidas no Laboratório de Microssonda Eletrônica do Instituto de Geociências da Universidade de Brasília. O equipamento utilizado foi a microssonda eletrônica modelo JEOL JXA-830 (EPMA), que apresenta feixe com $1 \mu \mathrm{m}$ de diâmetro. Durante as análises o equipamento foi operado com $15 \mathrm{kV}, 10 \mathrm{nA}$ e tempo de contagem de 10 s. 


\section{Manuscrito:}

Petrografia e geoquímica das formações ferríferas e rochas clásticas do Grupo Jacadigo, Neoproterozoico do sul da Faixa Paraguai 


\title{
4 Manuscrito: Petrografia e geoquímica das formações ferríferas e rochas clásticas do Grupo Jacadigo, Neoproterozoico do sul da Faixa Paraguai
}

\begin{abstract}
After a long period of non-deposition of iron formations, records of new deposits were observed in Neoproterozoic time, such as the iron formations from the Rapitan Group in Canada and from the Jacadigo Group at Urucum, Brazil. Neoproterozoic deposits of iron formations with manganese layers belonging to the Santa Cruz Formation, Jacadigo Group, occur near Corumbá and in adjacent Bolivia. New lithogeochemical analyses of major and trace elements together with petrography of fresh samples obtained from boreholes at the Santa Cruz iron ore deposit allowed comparing the rocks with data from adjacent Urucum and Rabicho hills and other Neoproterozoic iron formations. Detailed petrography of core samples from the Morraria Grande deposit, east of Morraria do Urucum, revealed that many substitution processes were active by the time of deposition or just after deposition. Analyses suggest that dolomitization affected the lower part of the sedimentary section and may have reached the upper $100 \mathrm{~m}$ at the top of the sequence, which later underwent leaching processes. Major elements and REE and $\mathrm{Y}$ results point to a large contribution of the clastic budget in the area, even during deposition of the chemical layers. General distribution of the REE from Morraria Grande "pure" iron formations samples shows slight enrichment of rare earth elements compared to the Urucum deposit. Added to the dominance of a more nodular facies instead of the banded facies and interbedded thicker layers of diamictite and lesser participation of manganese layers, the enrichment in REE suggests that the rocks at Morraria Grande were deposited in a shallow or marginal context of the Jacadigo basin.
\end{abstract}

\subsection{Introdução}

As mudanças decorrentes da fragmentação do Supercontinente Rodínia, no início do Neoproterozoico, resultaram em grandes transformações não só na superfície terrestre mas também na atmosfera e nos oceanos existentes (Hoffman, 1991; Bekker et al., 2010; Stern et $a l ., 2013)$. As principais evidências sedimentares deixadas por essas mudanças são os registros de eventos glaciais (Kirschvink, 1992; Hoffman et al., 1998, Hoffman \& Schrag, 2002), a 
formação de carbonatos de capa e a volta da deposição de formações ferríferas, após período de quase 1 Ga sem registro destes depósitos (Holland, 2006).

A repentina reaparição das formações ferríferas em associação com sequências glaciais no Neoproterozoico mostra que estas foram depositadas em contexto diferente das formações ferríferas arqueanas e paleoproterozoicas (Cox et al., 2013). A presença de oxigênio já disponível na atmosfera e de oceanos estratificados e com condições similares às dos oceanos modernos geraram assinaturas geoquímicas características para essas rochas. Uma feição marcante dessa mudança e que serve para diferenciar as formações ferríferas é a anomalia de $\mathrm{Eu}$, fortemente positiva nas formações ferríferas do tipo Algoma e presente nas formações ferríferas do tipo Lago Superior, porém ausente nas formações ferríferas do Neoproterozoico (Cox et al., 2013, Sial et al., 2015).

As formações ferríferas neoproterozoicas geraram depósitos evidentemente menores, quando comparados aos formados no fim do Arqueano e início do Proterozoico. Petrograficamente, apresentam aspectos texturais com menor presença de bandas em relação a nódulos de cherte e jaspe e sua deposição se deu próximo ou em meio a sequências glaciais, diferentemente de suas equivalentes mais antigas. A mineralogia das formações ferríferas neoproterozoicas é majoritariamente constituída por hematita, ou tem hematita como fase principal, enquanto magnetita aparece em menor quantidade, localmente, em regiões de falhas, ou como resultado de metamorfismo (Klein \& Beukes, 1993; Cox et al., 2013).

Apesar das formações ferríferas formadas no Neoproterozoico serem constantemente atribuídas a eventos glaciais, ocorrem ainda depósitos relacionados a rochas vulcânicas e depósitos do tipo plataformal (Xu et al., 2013; Gaucher et al., 2015; Khalil et al., 2015). Formações ferríferas associadas a sedimentos glaciais do Neoproterozoico são bem representadas pelos depósitos do Grupo Jacadigo (Brasil) e do Grupo Rapitan (Canadá), aos quais são atribuídas idades correspondentes às glaciações Marinoana e Sturtiana, respectivamente.

O objetivo deste trabalho é investigar as rochas do Grupo Jacadigo, na localidade de Morraria Grande, a sudeste da Morraria do Urucum e da cidade de Corumbá (MS). Foram utilizados, principalmente, dados de testemunhos de furos de sondagem da campanha de exploração do depósito de Santa Cruz. Com vistas ao detalhamento estratigráfico e à caracterização das formações ferríferas, foram investigados testemunhos de três furos de sondagem por meio de petrografia, litogeoquímica e química mineral. Optou-se por utilizar o 
termo formação ferrífera em detrimento do termo "formação ferrífera bandada", inicialmente usado para as formações ferríferas do Arqueano (Bekker et al., 2010), visto que boa parte da sequência descrita não apresenta bandamento definido e é amplamente composta por porções nodulares ou laminares.

\subsection{Contexto Geológico Regional}

As rochas sedimentares e metassedimentares neoproterozoicas depositadas no sudeste do Cráton Amazônico e no leste do Bloco Rio Apa, que incluem as rochas do Grupo Jacadigo, foram divididas estruturalmente em coberturas cratônicas plataformais e zonas interna e externa da Faixa Paraguai (Fig. 7). As coberturas plataformais depositadas sobre a margem cratônica se diferenciam por serem pouco deformadas e isentas de metamorfismo, enquanto as rochas que constituem as zonas externa e interna da faixa mostram deformação e metamorfismo progressivo de oeste para leste (Almeida, 1984; Alvarenga \& Trompette, 1993; Alvarenga et al., 2000).

A Faixa Paraguai foi formada durante o final da Orogenia Brasiliana (550-500 Ma) e se estende por quase $1500 \mathrm{~km}$, constituindo um arco que bordeja o Cráton Amazônico e o Bloco Rio Apa (Almeida, 1984). A faixa está exposta em duas porções: a setentrional, que acompanha a margem sudeste do Cráton Amazônico e a meridional, que constitui a Serra da Bodoquena e as morrarias do Urucum, margeando o Bloco Rio Apa. As duas porções são separadas pelas unidades sedimentares que formam as bacias do Pantanal e do Paraná, e que recobrem a maior parte da zona interna e parte da zona externa da Faixa Paraguai (Campanha et al., 2011).

As unidades estratigráficas que compõem a Faixa Paraguai e as coberturas cratônicas adjacentes, são objeto de dissenso a respeito de seus limites e nomenclatura, sendo aplicados nomes para a porção setentrional diferentes da porção meridional, e das sequências localizadas nos vizinhos Bolívia e Paraguai. Em face disso, optou-se pela classificação, de caráter mais abrangente, proposta por Alvarenga et al. (2000), e possível de ser aplicada na porção meridional. Segundo Alvarenga et al. (2000), as unidades litoestratigráficas que compõem a faixa e a cobertura cratônica podem ser divididas em unidades inferior, de natureza turbidíticaglaciogênica, média, de natureza carbonatada, e superior, de natureza siliciclástica. As variações destas fácies ocorrem lateralmente. A oeste expõem-se depósitos glácio-marinhos de ambiente plataformal que passam, a leste, para sedimentos que foram depositados em bacia mais profunda, com a presença de turbiditos (Alvarenga \& Saes, 1992; Alvarenga \& Trompette, 1992). 


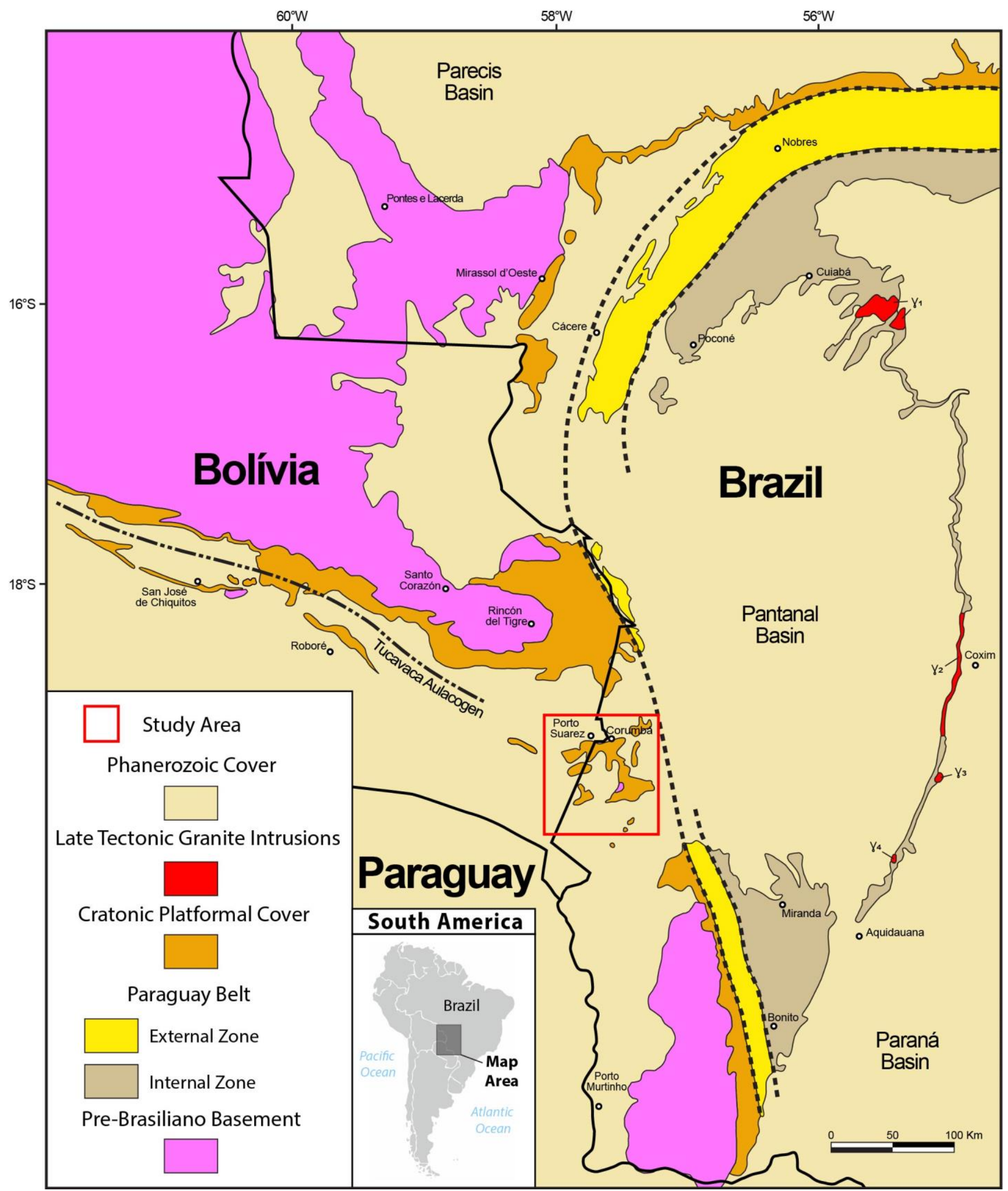

Figura 7 - Mapa simplificado da porção sudeste do Cráton Amazônico e do Bloco Rio Apa, com destaque para as coberturas cratônicas e a Faixa Paraguai (modificado de Alvarenga \& Trompette, 1993). Linhas pontilhadas - Limites das zonas da Faixa Paraguai; Linha tracejada/pontilhada - Eixo do Aulacógeno Tucavaca. V granitos (1) São Vicente; (2) Coxim; (3) Rio Negro; (4) Taboco. 
As rochas pertencentes ao Grupo Jacadigo (Fig. 7) fazem parte da unidade inferior dos sedimentos plataformais da margem cratônica, depositados sobre a margem do Bloco Rio Apa. As coberturas plataformais cratônicas acompanham a Faixa Paraguai e se estendem para o interior do cráton, chegando até $500 \mathrm{~km}$ a partir da sua borda, sobretudo na Bolívia (Almeida, 1984; Alvarenga \& Trompette, 1993).

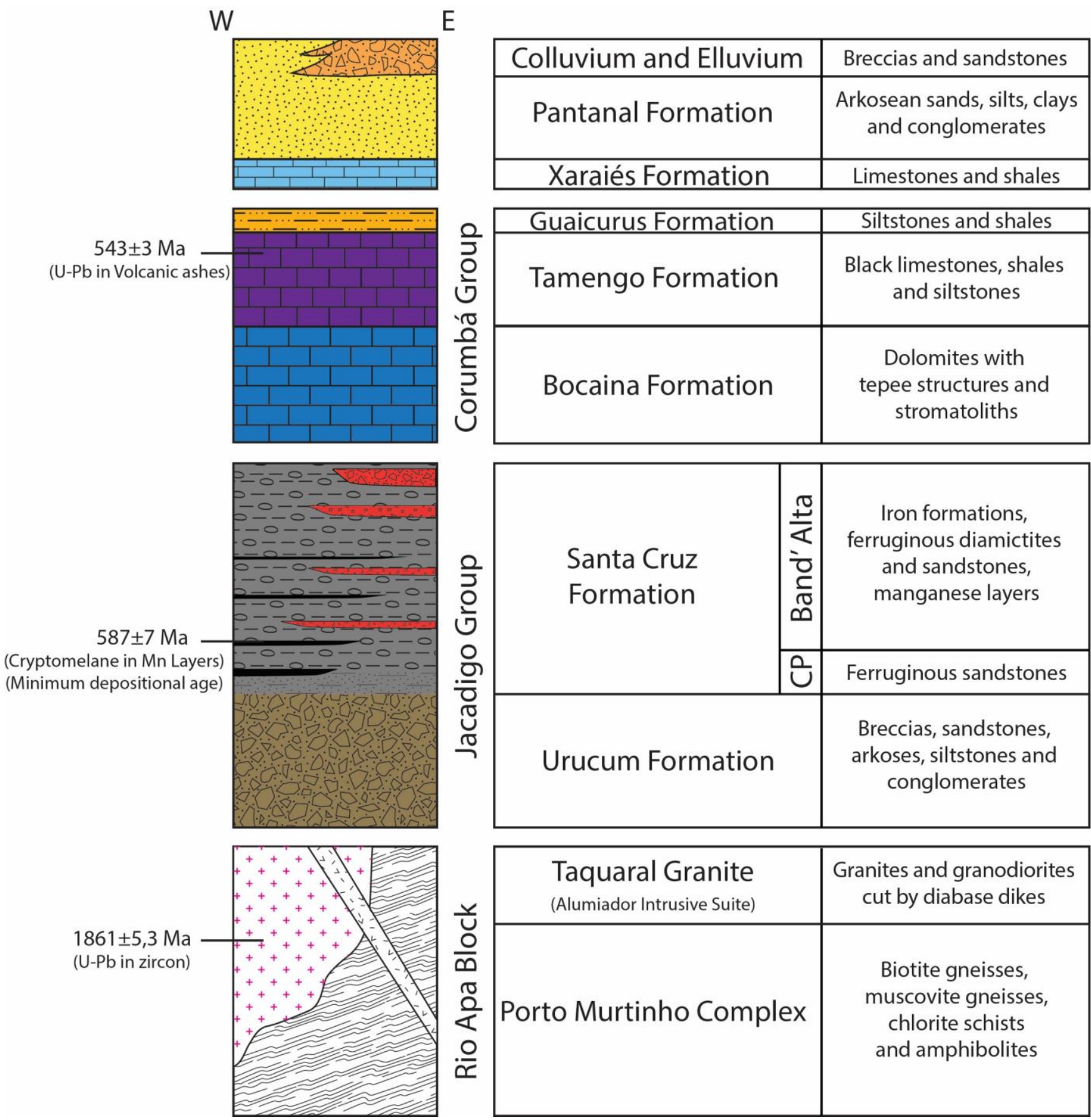

E

Figura 8 - Coluna estratigráfica da região de Corumbá com as unidades mapeáveis e respectivas idades. CP - Córrego das Pedras. Modificado de Haralyi \& Walde (1986), Urban et al. (1992) e Piacentini et al. (2013). 
As rochas do Grupo Jacadigo na área de estudo (Fig. 8) estão depositadas em inconformidade sobre o embasamento paleoproterozoico, formado por gnaisses e xistos deformados do Bloco Rio Apa, e granitos intrusivos nestas rochas, expostas na base das morrarias e próximo a Corumbá. Os gnaisses e granitos são intrudidos por diques de dacitos e dioritos observados em Corumbá e próximo à morraria do Urucum (Dorr II, 1945). Os granitos que intrudem o embasamento mais antigo apresentam idade de ca. $889 \mathrm{Ma}$ (K-Ar, Almeida, 1984; Urban et al., 1992).

Inicialmente definido por Lisboa (1909), e posteriormente dividido em duas formações, o Grupo Jacadigo compreende a Formação Urucum, composta de conglomerados e arcósios, e a Formação Santa Cruz, formada por espessos pacotes de formação ferrífera, lentes de arenitos grossos, brechas de matriz ferruginosa e camadas manganesíferas (Almeida, 1945). Dorr II (1945), em relatório ao United States Geological Survey (USGS), propôs a divisão do Grupo Jacadigo em três formações, ao separar a Formação Santa Cruz em Formação Córrego das Pedras, relativa aos arcósios ferruginosos e transicionais com a Formação Urucum, e a Formação Band'Alta, das formações ferríferas e diamictitos.

Ao redor dos locais onde afloram as rochas do Grupo Jacadigo são encontradas as rochas carbonáticas do Grupo Corumbá, formando morrarias de menor altitude e extensão. O posicionamento destas rochas na coluna estratigráfica da região e sua relação com o Grupo Jacadigo vêm sendo amplamente interpretados como posterior, apesar da ausência de evidências do contato direto entre os dois grupos. O principal argumento se baseia na similaridade com os carbonatos da porção setentrional da Faixa Paraguai, onde recebem o nome de Grupo Araras e também encerram a deposição de sedimentos glaciais, com seus carbonatos recobrindo sequências glaciais (Almeida, 1984; Alvarenga \& Saes, 1992, Alvarenga et al., 2011). 


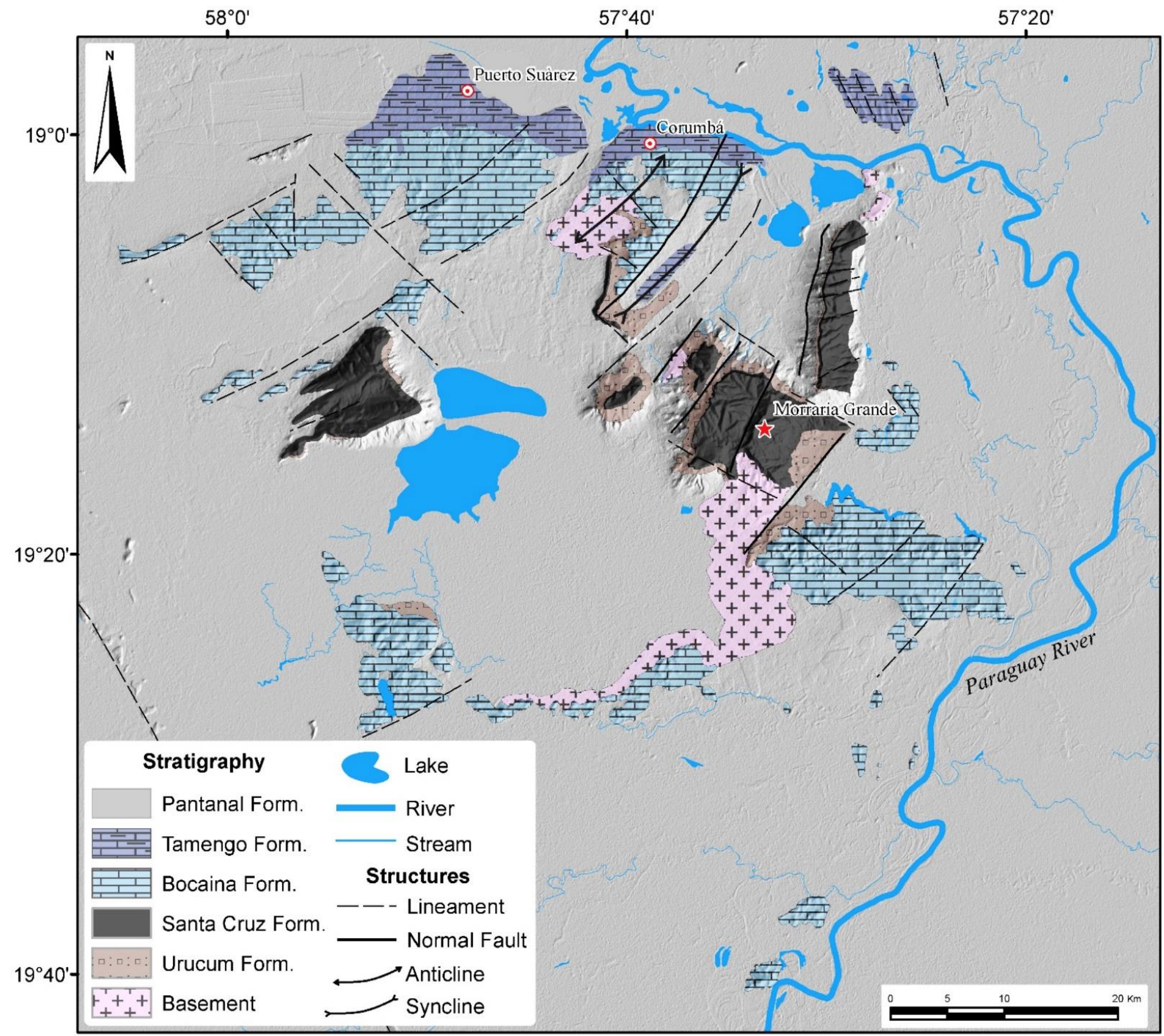

Figura 9 - Mapa Geológico da região de Corumbá (modificado de Weiss \& Sweet, 1959. Walde, 1988; Freitas, 2010). 


\subsection{Geologia da Morraria Grande}

Na Morraria Grande, a sudeste da Morraria do Urucum, o Grupo Jacadigo encontra-se depositado em inconformidade sobre granitos, gnaisses e clorita xistos pertencentes ao bloco Rio Apa. Os gnaisses que sustentam parte do depósito e formam o embasamento no centro e norte da morraria aparentam ser intrudidos por granitos rosados mais jovens sem deformação aparente e que afloram na porção sudoeste da morraria. Próximo a Corumbá as rochas graníticas receberam o nome de Granito Taquaral e foram datadas em $1861 \pm$ 5,3 Ma (U-Pb em zircão, Redes et al., 2015). Na Morraria Grande estas rochas estão afetadas por falhas de direção WNW-ESSE, que compartimentam o embasamento em blocos e criam altos estruturais. Nas áreas em que o embasamento se encontra soerguido, as rochas do Grupo Jacadigo apresentam espessura variável, com sua base se mantendo correlacionável às outras porções do depósito. As falhas são posteriores à sedimentação, apesar de possivelmente serem resultado da reativação de falhas antigas do embasamento.

Sobre o embasamento estão depositadas, em discordância erosiva, as rochas pertencentes à Formação Urucum, que consistem em brechas e arenitos arcoseanos grossos e médios formados de material do embasamento retrabalhado (Fig. 10). A Formação Urucum é caracterizada por composição arcoseana e cimento carbonático em partes de sua matriz. A ausência de ferro marca essa unidade e ajuda a diferenciá-la das outras unidades. A sequência apresenta ciclos de granodecrescência ascendente, com ciclo inicial formado por volumoso pacote de brechas de granulação grossa na base.

As brechas que formam a base da sequência são clasto-suportadas e formadas por blocos angulosos de granitos e rochas calcissilicáticas, que podem chegar até $10 \mathrm{~m}$ de diâmetro em testemunhos de sondagem. Preenchendo o espaço entre os blocos, há a presença de areia e silte em proporções variadas. Acima das brechas ocorrem orto- e paraconglomerados com clastos menores e maior grau de arredondamento, que ciclicamente passam para arenitos arcoseanos médios e grossos, de cor cinza e branca. Os arenitos arcoseanos adquirem cor levemente esverdeada em algumas localidades, devido à presença de clorita, possivelmente resultado de autigênese durante a sedimentação, ou da erosão de partes metamorfizadas do embasamento. 

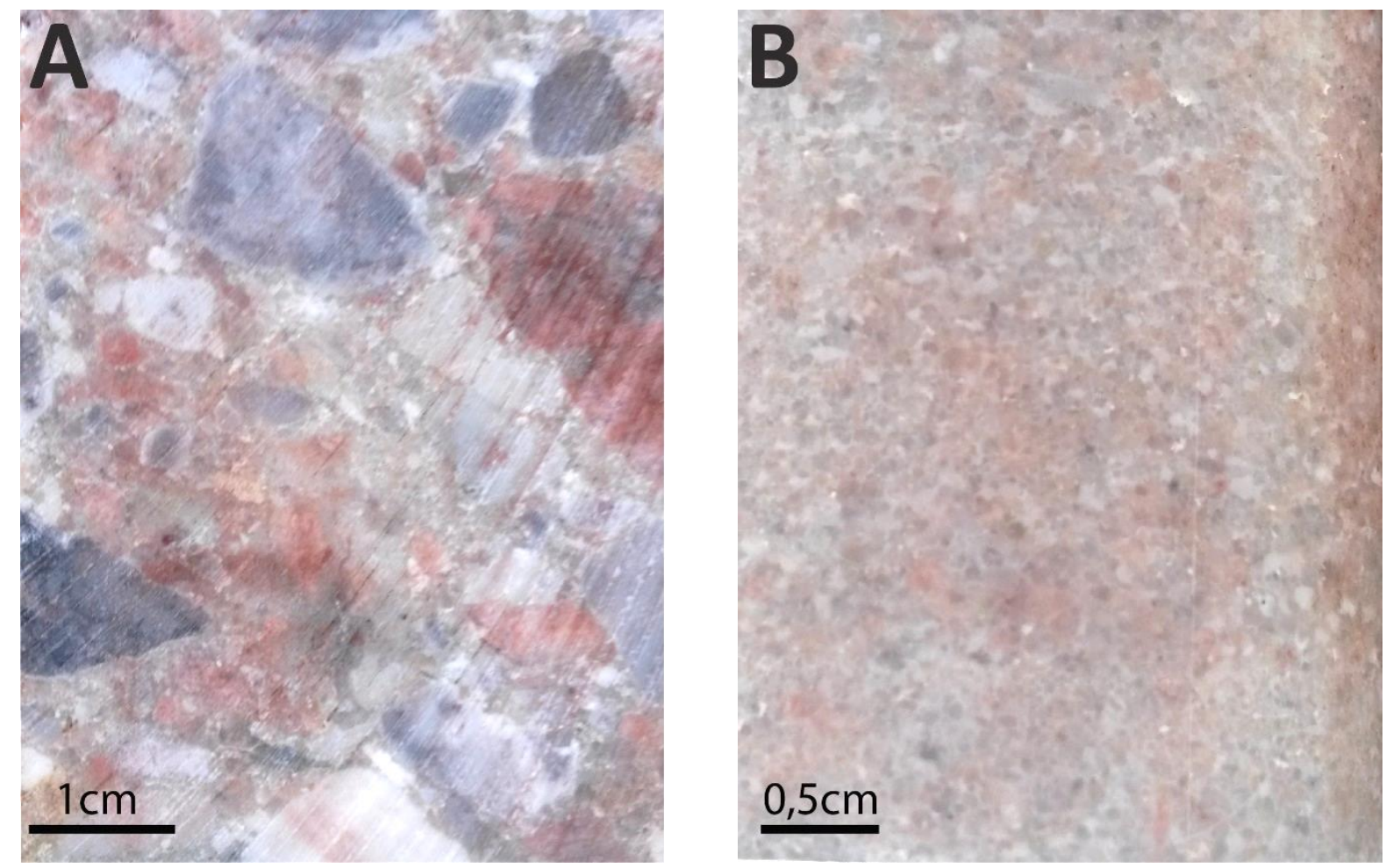

Figura 10 - Amostras de testemunho de sondagem: (A) camada de brechas da Formação Urucum, com clastos de mármore e de granito; (B) arenito arcoseano médio/grosso que ocorre acima dos intervalos de brecha. Porções avermelhadas de óxido de ferro podem ser observadas.

A sequência transiciona no topo para camadas de siltitos e arenitos finos e médios de cor cinza clara e escura com matriz carbonática. Pequenas quantidades de óxido de ferro foram observadas na matriz dos sedimentos arcoseanos, dando cor vermelha clara a algumas porções da rocha e marcando o início da sedimentação química na sequência. Intervalos de coloração cinza escura são encontrados na parte superior da formação devido à presença de manganês na matriz. O limite superior da formação é estabelecido por arenitos arcoseanos que apresentam óxido de ferro disseminado em sua matriz.

$\mathrm{Na}$ base da Formação Urucum, na porção nordeste da Morraria Grande, foram observados veios de sulfeto (pirita) cortando o acamamento, e alcançando as porções basais da Formação Santa Cruz. Dados geofísicos obtidos em levantamento pelo método IP (Polarização Induzida) sugerem anomalias de alta cargabilidade nessa área, que poderiam estar associados à presença de sulfetos (Coffey, 2014).

Os sedimentos clásticos e químicos logo acima da Formação Urucum foram individualizados por Dorr II (1945) como Formação Córrego das Pedras. A formação foi definida como de natureza transicional entre os depósitos não ferruginosos e as camadas de formações ferríferas da Formação Band'Alta. A análise de testemunhos de vários furos de 
sondagem permitiu observar as características desta formação e foi constatado que sua espessura é muito variável, com valores que não ultrapassam $15 \mathrm{~m}$. A unidade também não está presente em algumas porções do depósito, o que dificulta seu mapeamento e representação em mapas. Estes fatores levaram a propor que as formações acima citadas seriam melhor definidas como membros da Formação Santa Cruz (Almeida, 1945) constituindo, assim, os membros Córrego das Pedras e Band'Alta (Haralyi \& Walde, 1986; Urban et al., 1992; Klein \& Ladeira, 2004), mantendo os limites litoestratigráficos propostos por Dorr II (1945).

A passagem da Formação Urucum para o Membro Córrego das Pedras se dá de maneira gradativa, com o aparecimento de pequenas porções ferruginosas na parte superior da formação. O Membro Córrego das Pedras é composto por conglomerados e arenitos arcoseanos de aspecto similar aos encontrados no topo da Formação Urucum, sendo a única diferença associada à presença de óxido de ferro em sua matriz. Os depósitos encontrados são arenitos conglomeráticos que apresentam clastos parcialmente retrabalhados de granitos, rochas carbonáticas de cor cinza e mármores brancos. Na parte superior a sequência passa para arenitos arcoseanos e ferruginosos médios e finos com lentes de formações ferríferas ou manganesíferas subordinadas às camadas clásticas. Em algumas partes da Morraria Grande, onde o embasamento se encontra soerguido, é possível observar as rochas clásticas ferruginosas diretamente sobre o embasamento, sugerindo que os altos do embasamento estavam presentes quando da sedimentação.

O Membro Band'Alta se inicia na primeira camada de formação manganesífera ou na primeira camada maciça de formação ferrífera mais pura (Dorr II, 1945). Na Morraria Grande a unidade é composta por formações ferríferas de composição hematítica e cherte, que apresentam espessas lentes de diamictitos e camadas ricas em manganês. As camadas manganesíferas, intercaladas nos extensos pacotes de formações ferríferas e diamictitos, são encontradas em todas as morrarias da região (Urban et al., 1992), no entanto sua espessura e número de camadas variam entre cada morraria. Na localidade da Morraria do Urucum Urban et al. (1992) definiram 4 camadas ricas em manganês intercaladas nas formações ferríferas e nos diamictitos.

As camadas manganesíferas na Morraria Grande são encontradas em pelo menos dois intervalos, e são identificadas por duas fácies, ocorrendo como formações ferríferas manganesíferas ou como arenitos arcoseanos finos e médios com minerais de manganês na matriz. A primeira camada, rica em manganês, mostra espessura de 1-3 m, ocorre próximo à 
base do Membro Band'Alta e faz contato ora com as rochas do Membro Córrego das Pedras, ora com os depósitos arcoseanos da Formação Urucum. A camada da base é composta por sedimentos ricos em manganês, que podem ser arenitos arcoseanos com presença de manganês ou formações ferríferas manganesíferas. A segunda camada, rica em manganês, tem espessura menor, variando de 0.2 a $1 \mathrm{~m}$ e está posicionada na zona lixiviada da seção logo acima da camada principal de formação ferrífera maciça ou laminar.

As formações ferríferas que compõem a unidade são constituídas por camadas de hematita especular (brilho metálico), formando a matriz que contém nódulos, lâminas e bandas de cherte e jaspe. Na Morraria Grande as formações ferríferas mostram predominância da fácies nodular, sendo esta mais marcante nas porções superiores do depósito, enquanto as fácies laminares e bandadas são mais frequentes em porções mais inferiores do depósito. Em profundidades de 80-120 m é encontrada fácies de formação ferrífera maciça com acamamento incipiente ou com lâminas finas de cherte separando a zona lixiviada superior da sequência da zona carbonatada inferior.

A fácies de formação ferrífera nodular contém nódulos formados por sílica criptocristalina, que são mais frequentes com a presença de óxido de ferro. Os nódulos ferruginosos mostram cor avermelhada clara que os destaca em meio à matriz hematítica de cor cinza metálico. Nódulos não ferruginosos são formados por sílica pura muito fina (cherte) com coloração branca e bege nas amostras de testemunhos de sondagem. Esses nódulos são encontrados, em graus variados de substituição, por hematita autigênica, que substitui a estrutura a partir do seu centro, mantendo preservadas as bordas de cherte puro (Fig. 11). 

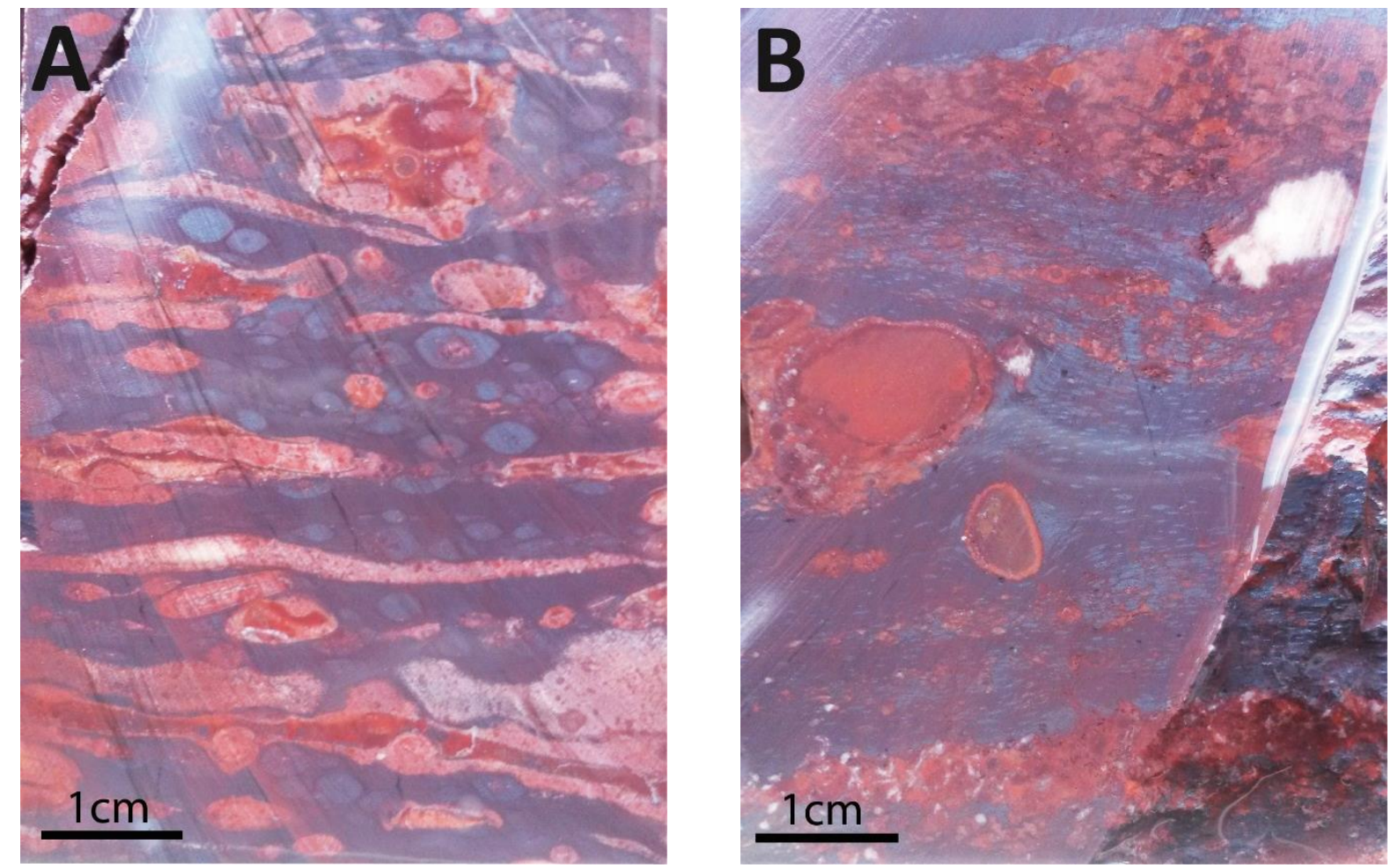

Figura 11 - Amostras de testemunho de sondagem: (A) formação ferrífera nodular com nódulos de cherteljaspe e nódulos substituídos por hematita especular formando a matriz; (B) nódulos menores substituídos compondo a matriz hematítica, com porções nodulares jaspilíticas ocorrem preservadas.

Nódulos de menor dimensão ocorrem amplamente substituídos e formando a matriz de hematita especular das rochas. Macroscopicamente, os nódulos substituídos por hematita apresentam-se intensamente deformados e achatados, ao ponto de formarem lâminas e lentes finas de hematita especular. A matriz de hematita especular, onde se encontram os nódulos, mostra textura finamente laminada e coloração cinza escura que a distingue dos nódulos substituídos por hematita que fazem parte dessa matriz e têm cor levemente mais clara.

A fácies de formação ferrífera laminar é composta por finas lâminas sub-horizontais de jaspe e cherte, que coexistem com bandas de jaspe e nódulos dispersos. Camadas isoladas estritamente laminares dificilmente são observadas na sequência. As formações ferríferas laminares se encontram em intervalos em que os nódulos sofreram forte deformação e estiramento, sendo possivelmente parte da sua origem resultado da compactação de nódulos. Algumas bandas e estruturas do tipo pods são comuns na formação ferrífera laminar. Em algumas amostras as bandas e pods mostram-se formadas por nódulos de jaspe em seu interior. As porções bandadas ocorrem em alguns pontos, em conjunto com as outras fácies ou fazendo parte delas. Os bandamentos observados nos testemunhos de sondagem são formados por camadas de espessura milimétrica/centimétrica (microbandamento) de natureza pouco extensa 
( $<10 \mathrm{~cm}$ de extensão). Muitas vezes dentro das bandas existentes ocorrem conjuntos de nódulos de jaspe preservados dos efeitos da substituição por hematita.

A porção superior do depósito (profundidades inferiores a $120 \mathrm{~m}$ ) se encontra intensamente lixiviada, com o processo afetando principalmente as estruturas sedimentares e retirando a sílica livre das rochas. A lixiviação nas camadas nodulares transforma os óxidos de ferro existentes em óxidos de ferro hidratado (limonita) (Fig. 12), conferindo coloração amarelada aos nódulos e camadas. Com a progressão da lixiviação, os nódulos são completamente lixiviados e se estabelece uma textura cavernosa (ou de "queijo suíço") na rocha. A fácies laminar das formações ferríferas na zona lixiviada tem suas lâminas extensivamente substituídas por limonita, o que torna a rocha susceptível a quebra e desplacamento.

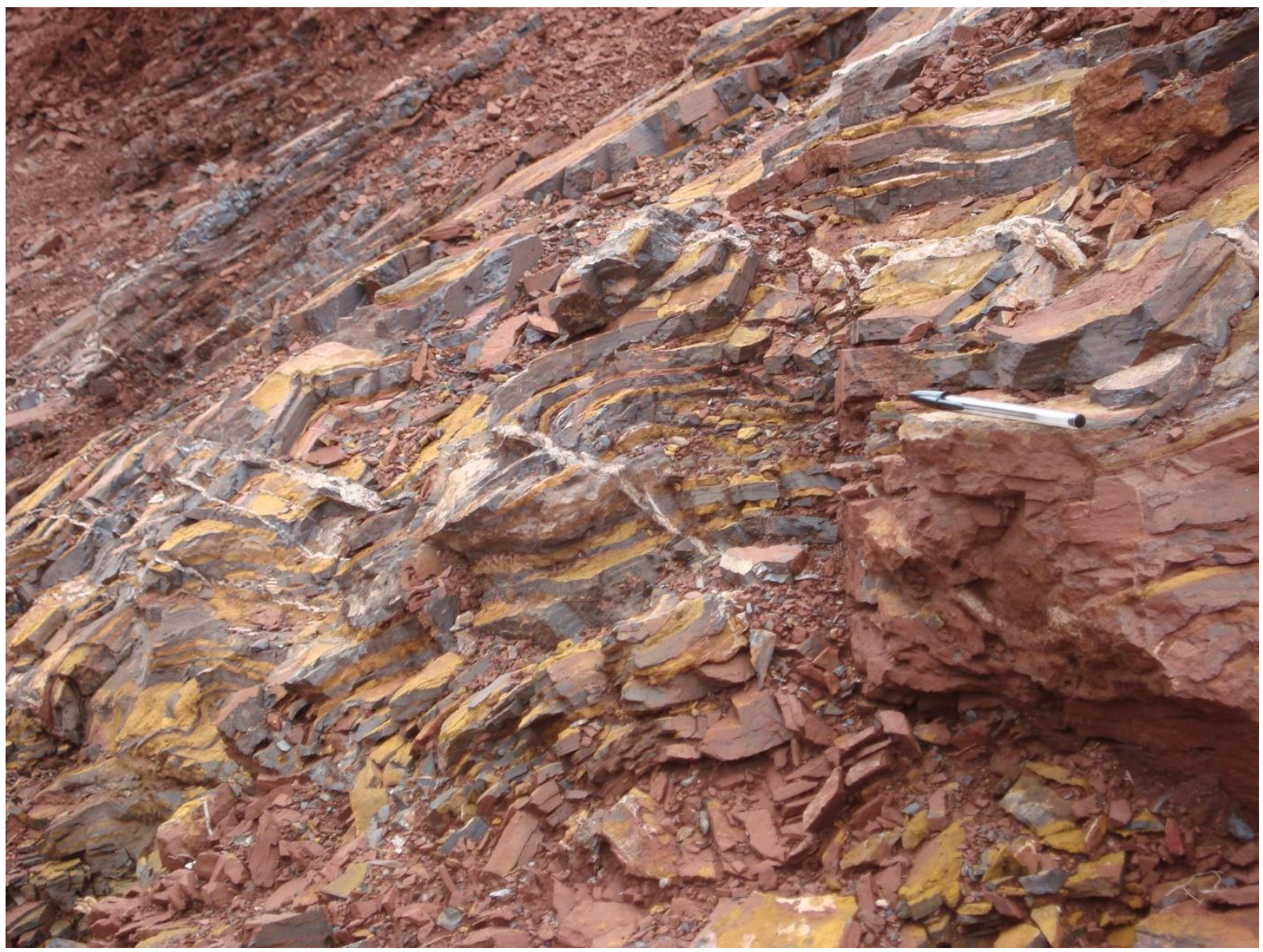

Figura 12 - Afloramento em bancada com formação ferrífera bandada com camadas e lâminas limonitizadas (cor amarela). Estrutura de slump cortada por veios de quartzo posteriores, região próximo a falha. Caneta à direita como escala. 


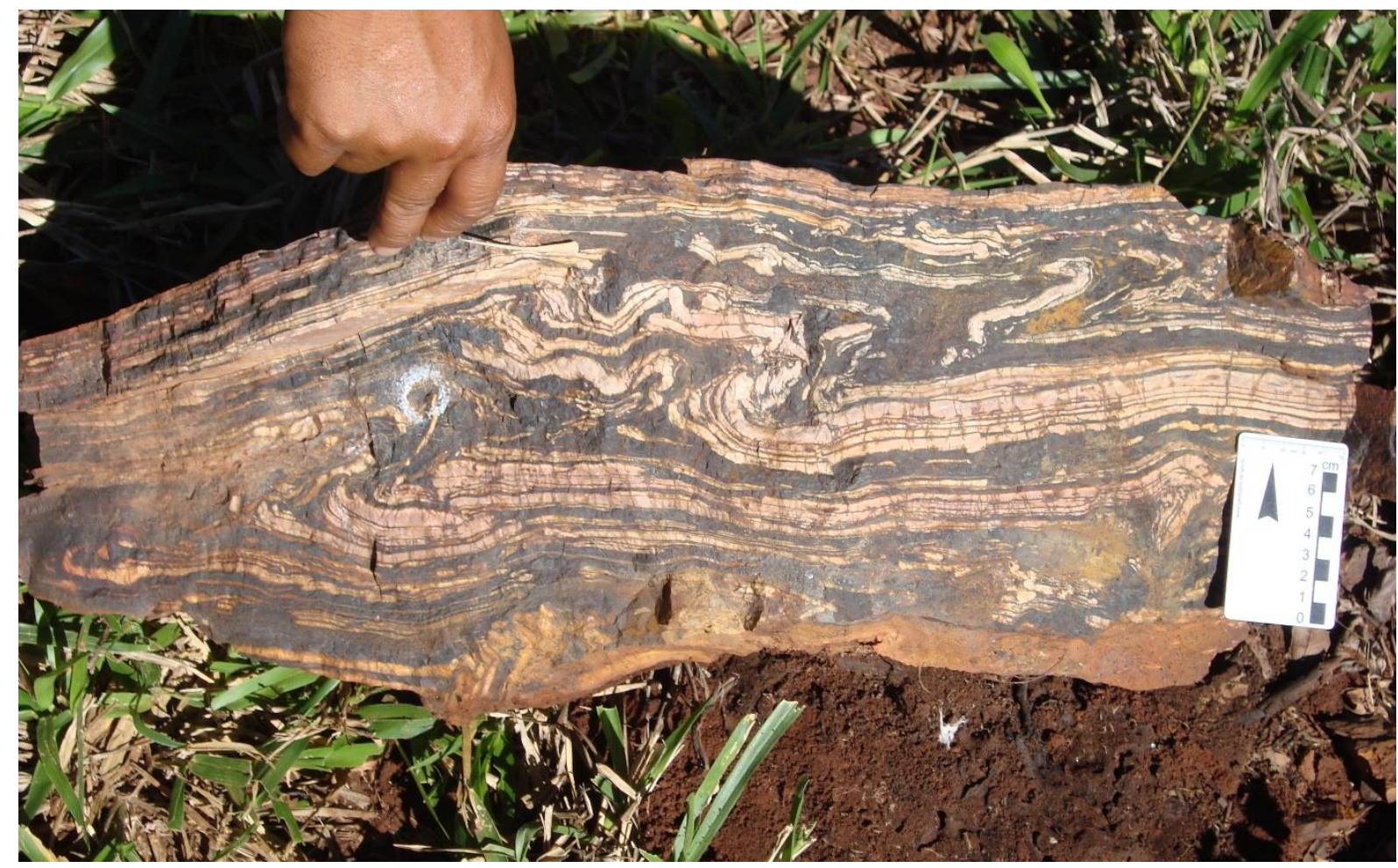

Figura 13 - Bloco de formação ferrífera bandada, apresentando bandas de cherte e hematita bem definidas, com estrutura de slump formada durante a sedimentação.

Em meio à sequência também são encontradas, localmente, estruturas sin-sedimentares representadas por slumps (Fig. 12,13) e brechas intraformacionais da formação ferrífera. As estruturas de slump são formadas por deslizamento rotacional das camadas, o que resulta na geração de dobramento durante a deposição (Debacker et al., 2001). Nos testemunhos de sondagem essa estrutura gera pequenas dobras centimétricas isoladas na porção superior da sequência, que não mostram repetitividade ou propagação para as camadas superiores e inferiores. Na parte superior de alguns furos de sondagem foi constatada a geração de acamamento convoluto, que evolui para extenso retrabalhamento das camadas na forma de brechas intraformacionais. Tanto em níveis rasos como em profundidade, as estruturas representam a remobilização de material devido a declives ou rampas de escorregamento na bacia.

Próximo às falhas e em algumas partes inferiores de furos de sondagem foi observada a formação de brechas hidráulicas afetando as camadas de formações ferríferas (Fig. 14). As rochas fragmentadas pelo processo de brechação não apresentam ampla substituição da matriz por hematita especular, como existe nas camadas comumente encontradas na sequência. As brechas encontradas são compostas por fragmentos de lamitos ferruginosos e silicificados, que contém pequenas quantidades de cristais de hematita autigênica dispersos em sua matriz. $\mathrm{O}$ 
espaço presente entre os fragmentos é preenchido pervasivamente por quartzo puro que cimenta o material. Em porções profundas veios de hematita estão presentes, cortando o acamamento e substituindo veios anteriores de sílica e carbonato. Veios de carbonato e de sílica, que cortam verticalmente camadas de hematita e cherte, mostram deformação por encurtamento devido ao peso da coluna de sedimentos acima. A porção do veio que corta a matriz hematítica mostra-se intensamente dobrada devido ao encurtamento da camada, enquanto que na matriz de cherte não há deformação.

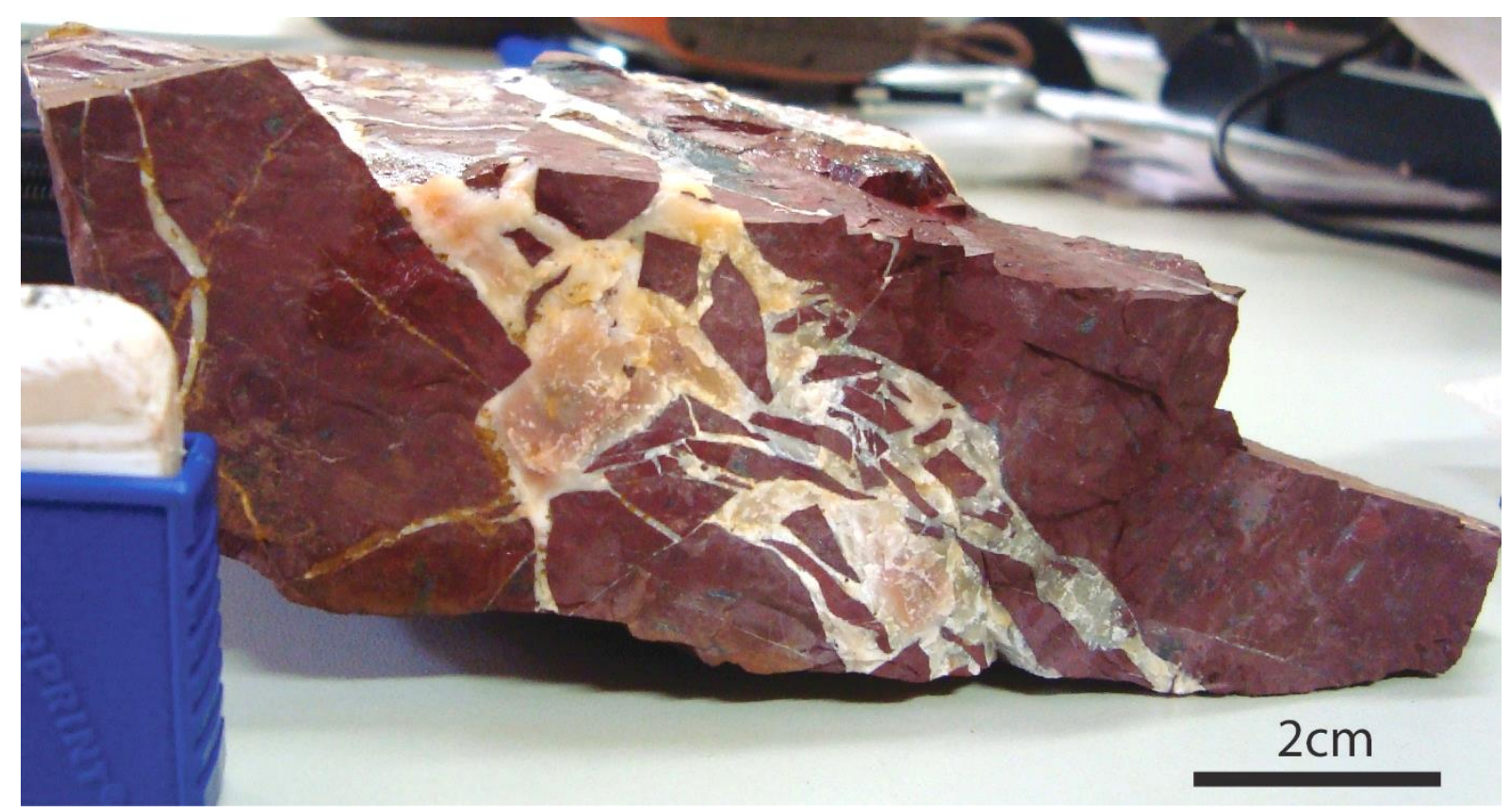

Figura 14 - Amostra de mão obtida de afloramento em região onde ocorre brechação hidráulica dentro do depósito; na matriz jaspilítica (vermelha) ocorrem pequenos cristais de hematita.

Intercaladas nas formações ferríferas ocorrem lentes de diamictito com espessuras que variam de 10 a $30 \mathrm{~m}$. Os diamictitos presentes são brechas polimíticas matriz suportadas, compostas por blocos angulosos de granito e gnaisses dispersos em meio à matriz arenosa e siltosa rica em ferro. Os diamictitos formam dois intervalos nos furos de sondagem, um na porção superior da sequência, e outro próximo ao contato da base da formação. O intervalo superior de diamictitos mostra a maior espessura, atingindo até $30 \mathrm{~m}$, enquanto o intervalo inferior apresenta espessura de até $20 \mathrm{~m}$. Os intervalos muitas vezes são segmentados em camadas menores ou mostram intercalações menores de camadas de formações ferríferas. Em alguns casos os siltitos e arenitos finos ferruginosos que compõem a matriz formam camadas pouco espessas dentro dos pacotes de diamictitos mais grossos. 


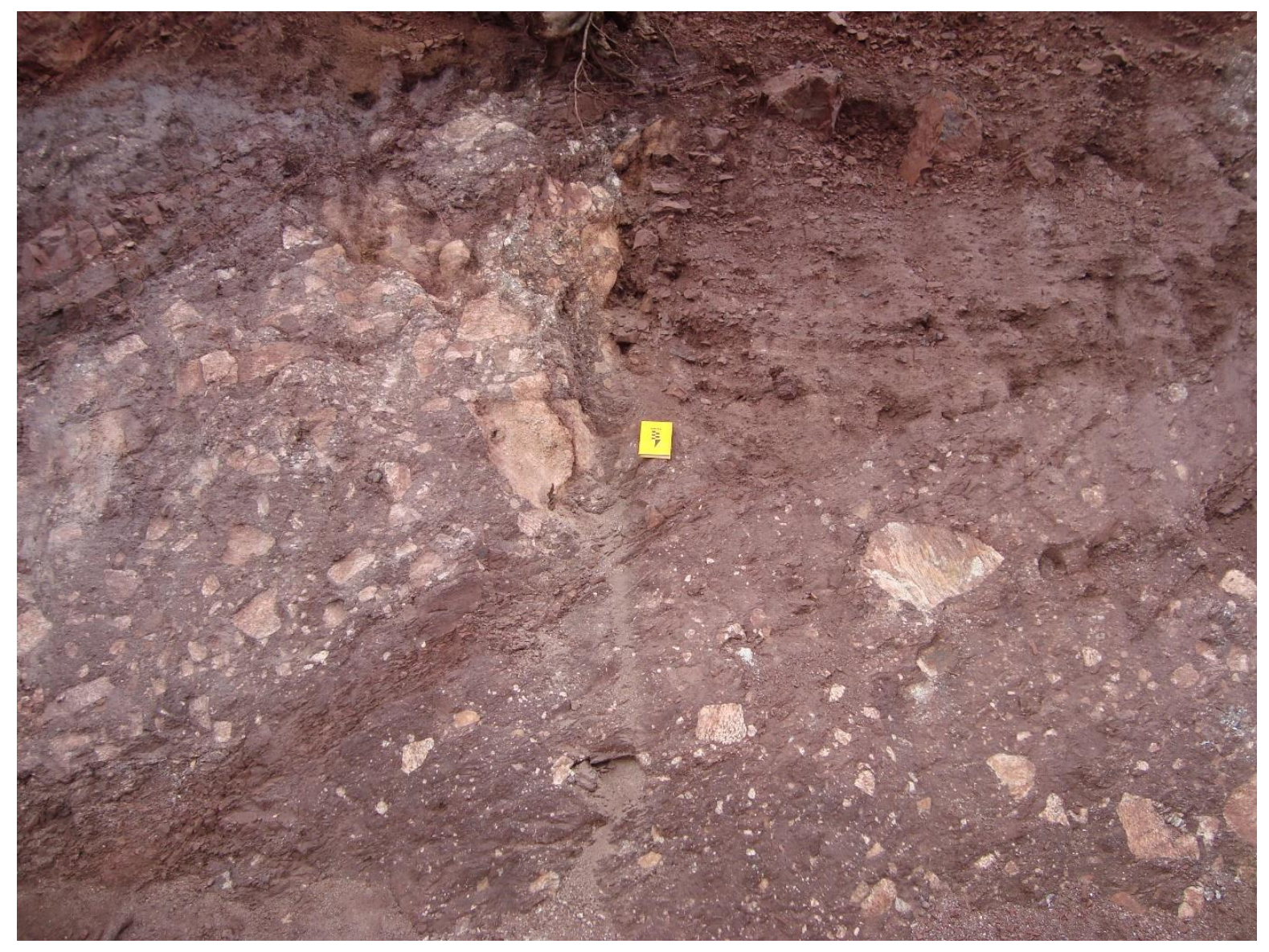

Figura 15 - Afloramento em bancada mostrando camada de diamictito ferruginoso grosso localizado na parte superior da Morraria Grande. Porções eluvionares e coluvionares de formação ferrífera recobrem o material.

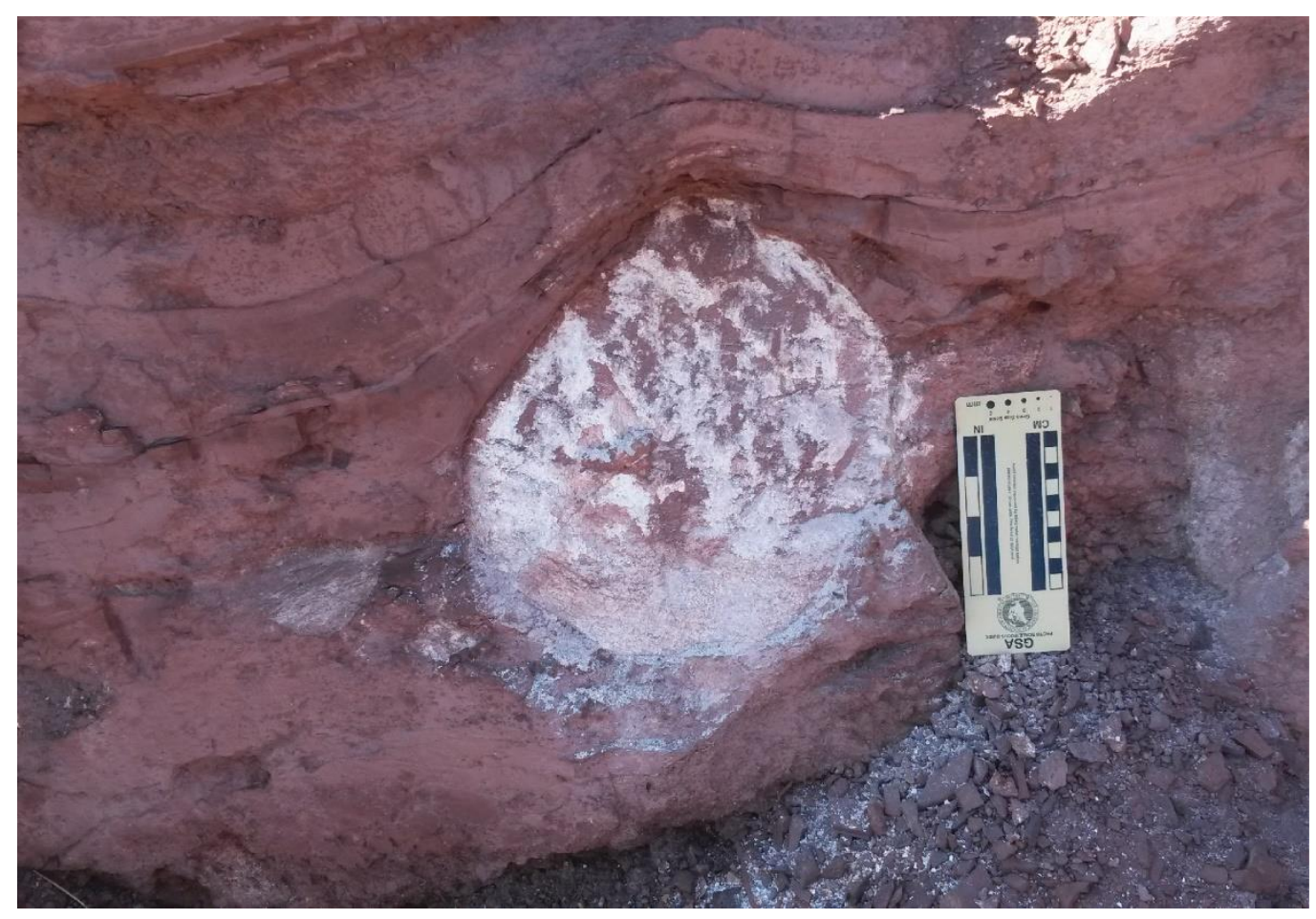

Figura 16 - Dropstone de granito em meio a arenito ferruginoso fino, afloramento em bancada da mina da Vetorial, Morraria Grande. Detalhe para diferença na deformação por queda de bloco nas camadas abaixo e deformação por compactação nas camadas acima do bloco. 


\subsection{Métodos}

O trabalho foi iniciado com o mapeamento executado em 2012, e posterior visita a campo realizada em 2015. Também foram realizadas análises de amostras de testemunhos de furos de sondagem, disponibilizados pela Vetorial Mineração. A coleta das amostras foi feita visando amostrar intervalos em que houvessem mudanças mineralógicas e texturais ou que registrassem processos da formação do depósito. Nestas amostras foram executadas análises petrográficas, litogeoquímicas e de microssonda eletrônica.

As lâminas foram confeccionadas pelos laboratórios de laminação da Fundação Gorceix e do Instituto de Geociências da Universidade de Brasília (UnB), e as análises e descrições petrográficas foram realizadas nos laboratórios de microscopia e geocronologia da UnB. Para a análise petrográfica das lâminas polidas foi utilizado microscópio polarizador e com dupla iluminação (transmitida e incidente) da marca Olympus, modelo BX-41. Após análise petrográfica, as lâminas foram polidas novamente e submetidas ao processo de metalização para análise em microssonda eletrônica de varredura. $\mathrm{O}$ equipamento utilizado foi a microssonda eletrônica modelo JEOL JXA-830 (EPMA), que apresenta feixe com $1 \mu \mathrm{m}$ de diâmetro. Durante as análises o equipamento foi operado com $15 \mathrm{kV}, 10 \mathrm{nA}$ e tempo de contagem de 10s. As análises de microssonda foram conduzidas no Laboratório de Microssonda Eletrônica do Instituto de Geociências da UnB.

Para as análises litogeoquímicas foram selecionadas 24 amostras segundo a textura e o tipo de rocha. As amostras coletadas são relativas a testemunhos de 3 furos de sondagem, sendo 10 amostras do furo SC, 7 amostras do furo MG e 7 amostras do furo UB, todos localizados na Morraria Grande (Fig. 17). A preparação das amostras foi executada no laboratório de Geocronologia da UnB, onde foram fragmentadas, e após obtidos os padrões de granulometria necessários, o material foi pulverizado em moinho de panela. A panela utilizada para a pulverização é da marca Brastorno e possui composição de liga metálica de alta dureza (vídia).

As análises litogeoquímicas foram conduzidas no Bureau Veritas Minerals Laboratories, Vancouver, Canadá. Foram executadas análises de ETR+Y e elementos maiores e menores (Tab. 3, 7). Para análise, as amostras preparadas foram misturadas a $\mathrm{LiBO}_{2} / \mathrm{Li}_{2} \mathrm{~B}_{4} \mathrm{O}_{7}$ e fundidas em forno. O material resfriado foi então dissolvido em ácido nítrico de grau analítico (ACS) e analisado em ICP-ES (Inductively Coupled Plasma-Emission Spectrometry) e ICPMS (Inductively Coupled Plasma-Mass Spectrometry). A perda por ignição (Loss on ignition 
- LOI) foi obtida submetendo uma parte de cada amostra a temperatura de $1000^{\circ} \mathrm{C}$ durante uma hora e pesando-a posteriormente.

\subsection{Petrografia}

\subsubsection{Análise dos testemunhos de furos de sondagem}

Os furos de sondagem analisados na Morraria Grande estão posicionados de oeste para leste, até o contato com as sequências sedimentares não ferruginosas que margeiam o depósito. Foram utilizados os furos UB, MG e SC, de leste para oeste (Fig. 17, 18). O furo MG contém os aspectos mais representativo da sequência, além de mostrar a maior espessura de sequência sondada ( $\sim 385 \mathrm{~m})$. O furo SC está localizado em uma parte mais alta da Morraria Grande a oeste, onde encontra rapidamente o embasamento granítico que sustenta a morraria. O furo UB se inicia em sedimentos não ferruginosos seguindo-se as formações ferríferas e diamictitos abaixo.

Os furos de sondagem interceptam camadas de formações ferríferas nodulares, laminares/nodulares, diamictitos ferruginosos, formações ferríferas com estratos clásticos e sedimentos não ferruginosos representados por brechas finas e grossas. Formações ferríferas bandadas ocorrem em pequenos intervalos associados às porções nodulares e laminares. As fácies laminar e bandada são mais comumente encontradas nas profundidades maiores dos furos de sondagem, enquanto a fácies nodular está mais presente na parte superior. Em virtude dos processos de intemperismo na parte superior da sequência, as fácies laminar e bandada são de difícil identificação, pois os planos de acamamento presentes nessas fácies são propensos a quebra e desplacamento.

As análises geoquímicas de amostras de testemunhos de sondagem permitiram correlacionar cada tipo litológico à sua respectiva resposta geoquímica. Os resultados demostraram que as camadas de diamictito são marcadas por queda no valor de ferro, enquanto sílica, alumínio e titânio mostram aumento em seus valores. A distribuição de ferro ao longo dos testemunhos apresenta padrão inversamente proporcional ao da sílica. Nas porções superiores dos furos ocorre forte ação de processos de intemperismo e lixiviação, que são responsáveis pela retirada da sílica e consequente aumento no volume de ferro. A lixiviação da parte superior é bem marcada pela ausência de carbonato. 


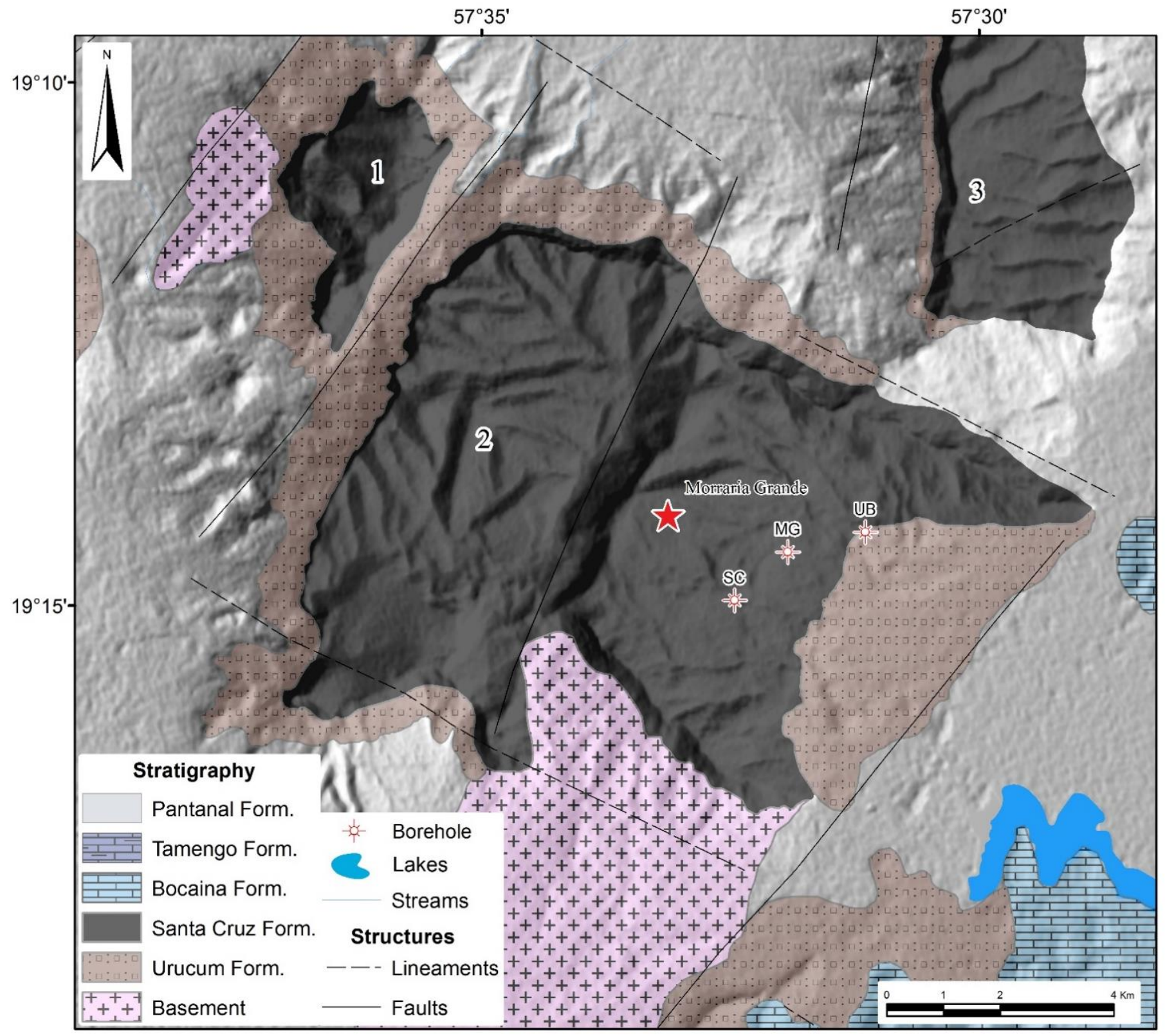

Figura 17 - Mapa com a localização dos furos de sondagem (SC; MG; UB) e as Morrarias adjacentes à Morraria Grande (1 - Morraria do Urucum; 2 - Morraria de Santa Cruz; 3 - Morraria do Rabichão). 


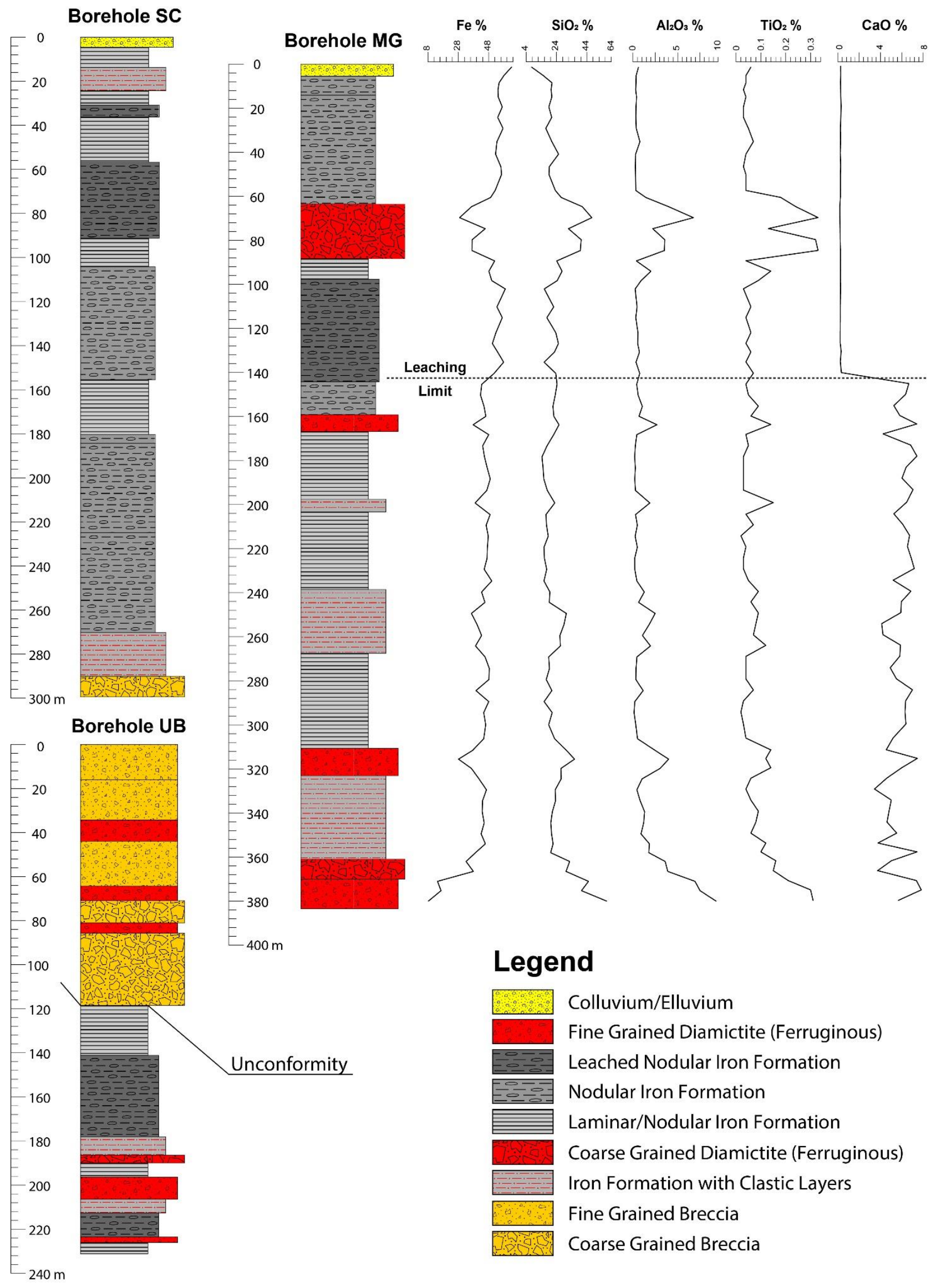

Figura 18 - Furos de sondagem utilizados (MG, UB e SC) do depósito da Morraria Grande. Furo MG com seu respectivo perfil geoquímico para ferro, sílica, alumínio, titânio e cálcio (suporte amostral de $5 \mathrm{~m}$ ). 


\subsubsection{Aspectos micropetrográficos}

As formações ferríferas não metamorfizadas preservam vários estágios de evolução textural associados a sedimentação e diagênese. Durante processos sin- e pós-deposicionais podem ocorrer solubilização e precipitação de fases minerais. Em alguns casos os estágios de formação ou lixiviação dessas fases não se encontram completos e permitem identificar quais eventos e processos modificaram a rocha durante sua evolução (Dimroth \& Chauvel, 1973). O estudo de lâminas e amostras das rochas do Grupo Jacadigo teve como objetivo descrever e identificar tais eventos e processos que formaram e afetaram as rochas encontradas no depósito.

A partir das lâminas e da descrição de rochas das formações Santa Cruz e Urucum, foram individualizadas 9 microfácies nas amostras coletadas. As principais fácies descritas correspondem a formação ferrífera nodular (FFN), formação ferrífera laminar (FFL), formação ferrífera bandada (FFB), diamictito ferruginoso (DF) e formação ferrífera com níveis clásticos (FFNC). Fácies intermediárias ou de transição e de menor espessura são compostas por formação ferrífera brechada (FFBR), arenito ferruginoso (AF), brecha arcoseana (BRA) e arenito arcoseano (ARA).

A formação ferrífera nodular (FFN) é a fácies mais comum do Membro Band'Alta. As rochas dessa fácies apresentam nódulos de cherte e/ou jaspe imersos em matriz hematítica especular ou em meio a matriz de sílica microcristalina. Em lâmina observa-se que os nódulos são formados por mistura de cherte e jaspe em seu centro e transicionam para composição de cherte pobre em óxido de ferro nas bordas da estrutura (Fig. 19). Outra forma de ocorrência dos nódulos é compondo a matriz hematítica, em que os nódulos que sofreram substituição completa da sua estrutura passam a compor a matriz de forma maciça ou laminar na formação ferrífera.

A substituição por hematita ocorre primeiramente no contato com a matriz, entre os nódulos, e na parte central dos nódulos (Fig. 19). A borda dos nódulos ricos em jaspe ou ricos em cherte se mantém preservada em grande parte das amostras da fácies nodular e somente em estágios mais avançados há a substituição completa dos nódulos. No contato entre os nódulos, que ocorrem de forma pouco espaçada, formam-se finas lâminas de hematita especular no início da substituição, destacando, assim, a forma dos nódulos e segmentando as porções de cherte dentro da matriz. 


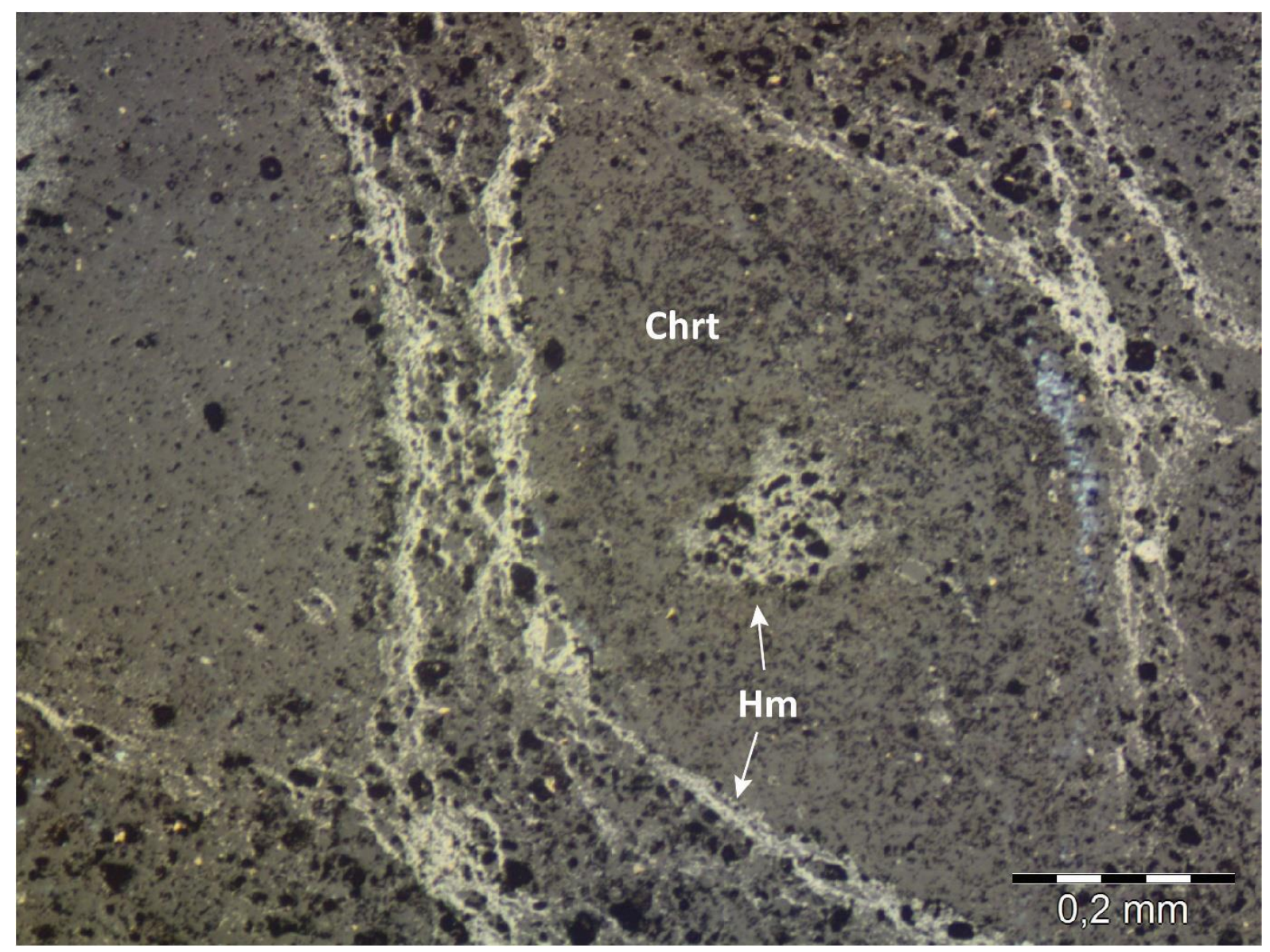

Figura 19 - Fácies nodular mostrando nódulos de cherte com início de substituição por hematita. A hematita se forma inicialmente no contato e no centro dos nódulos. XPL, Luz refletida e transmitida.

Os nódulos ricos em cherte e os nódulos substituídos por hematita especular aparentam coexistir em diversas amostras de formações ferríferas analisadas, apesar de mostrarem diferenças marcantes em relação a forma e deformação. Nódulos que sofreram substituição mais intensa se encontram deformados e dando origem a lentes finas em meio a matriz. Os nódulos parcialmente substituídos ou preservados se mantêm com sua forma arredondada original (Fig. 20). Nódulos de menor tamanho $(<0,3 \mathrm{~cm})$ mostram terem sido substituídos mais rapidamente em comparação com nódulos de tamanhos maiores $(>0,4 \mathrm{~cm})$, que ainda são encontrados preservados com sílica criptocristalina em seu interior. 


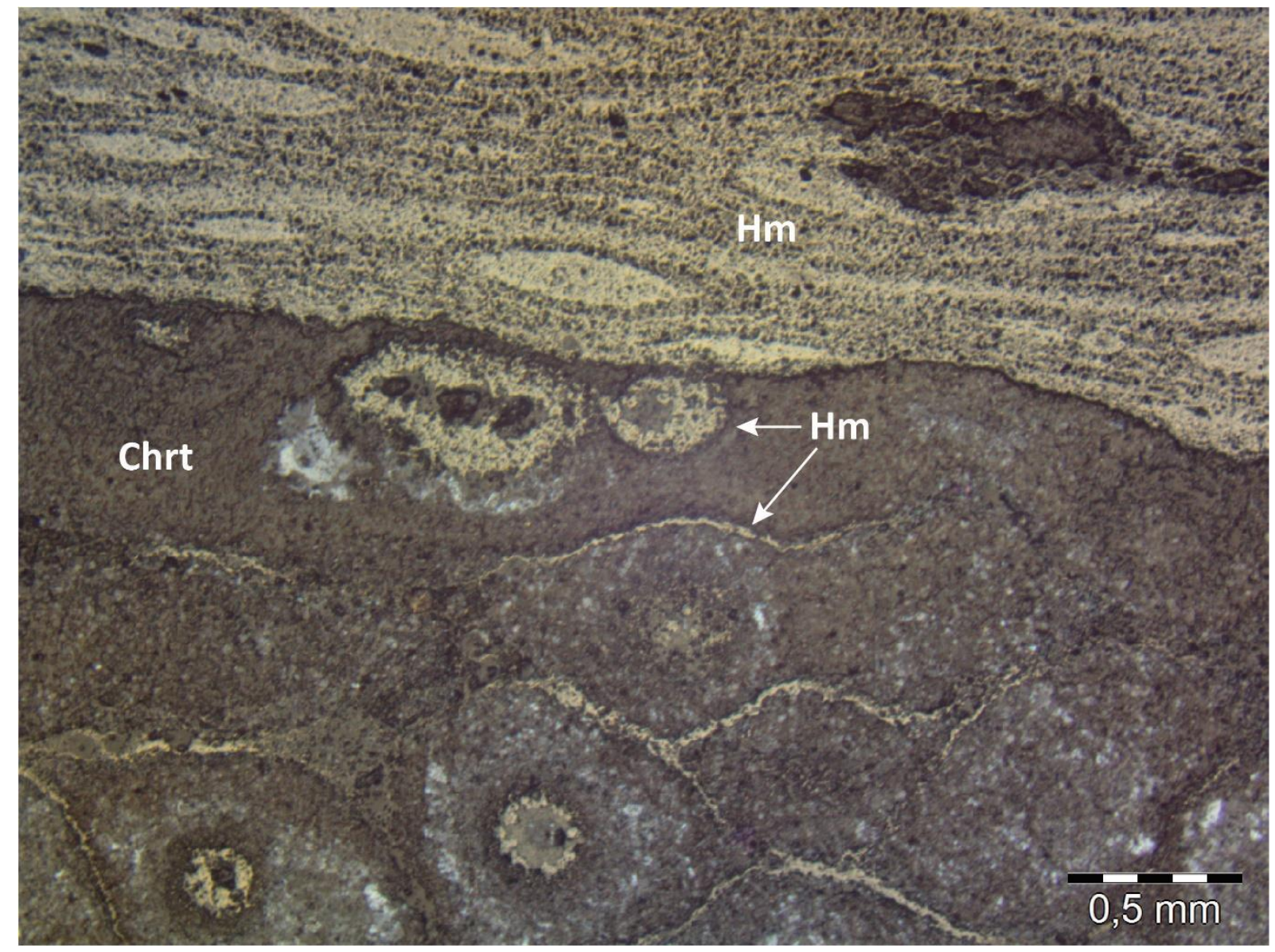

Figura 20 - Formação ferrífera nodular parcialmente substituída por hematita especular. Notar deformação dos nódulos após a substituição na parte superior e a porção preservada de nódulos de cherte na parte inferior. Hematita ocorre no contato dos nódulos. O aspecto de ferrugem na parte hematítica se dá pela preservação de diminutos cristais de cherte/jaspe em meio à matriz substituída. XPL, Luz refletida e transmitida.

Em certos intervalos nodulares e bandados preservados com cherte e jaspe, estruturas de contração (skrinkage structures) se desenvolveram, afetando nódulos e bandas. As estruturas afetam principalmente a parte interna dos nódulos e bandas ricos em cherte, sem mostrar transposição para a matriz (Fig. 21). A estrutura resulta da fragmentação das bandas ou nódulos silicosos por compactação e abertura de espaços no interior dessas estruturas. Os espaços gerados nessas estruturas são preenchidos por micro-cristais de quartzo recristalizado que se diferenciam pela cristalinidade e tamanho de grão em relação à matriz de cherte do nódulo ou da banda. No interior de alguns nódulos de cherte, e em níveis clásticos substituídos por cherte, são encontrados pequenos cristais de cor vermelha, que análises de raio-x indicaram corresponder a anquerita (Fig. 22). 


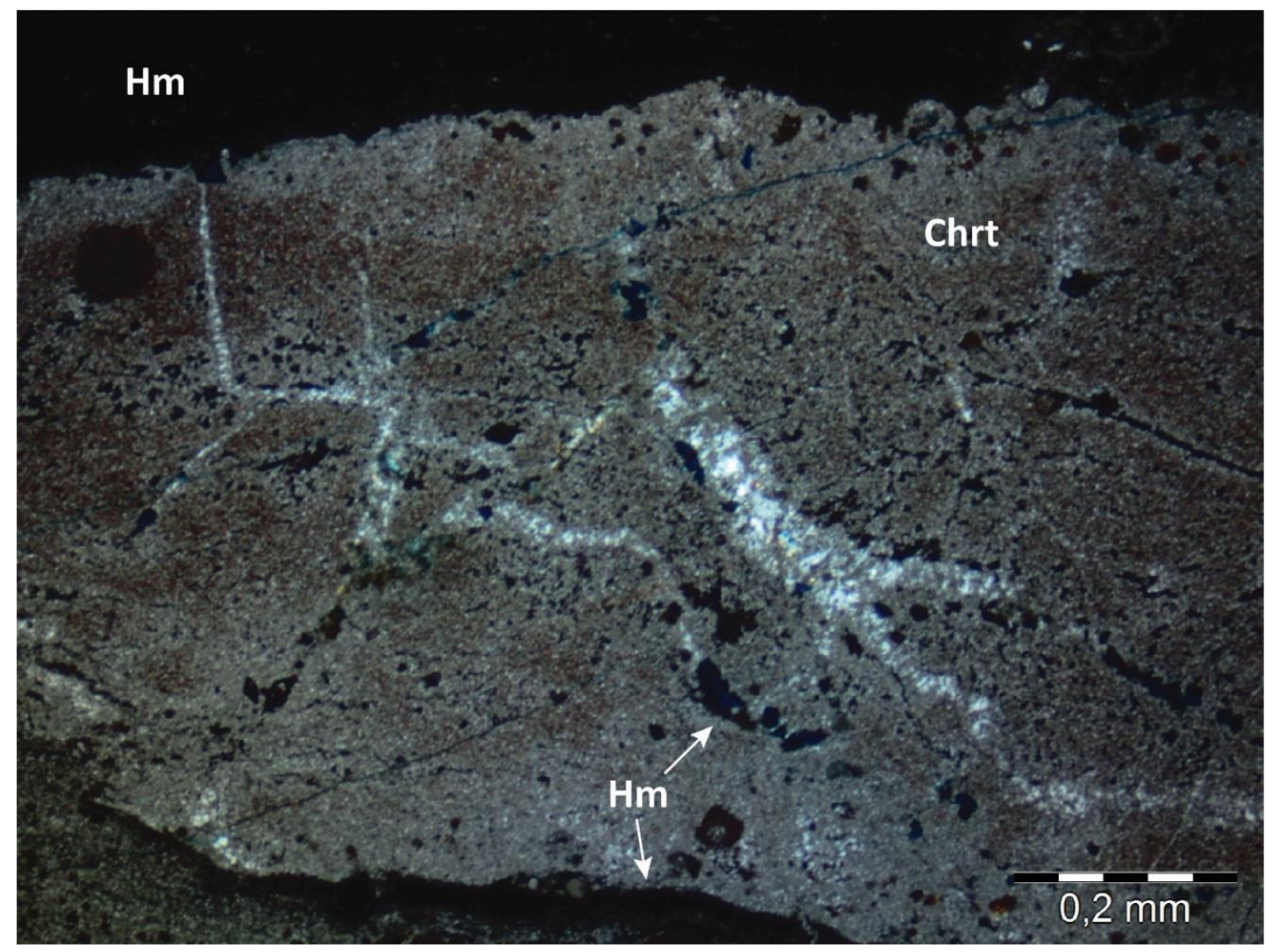

Figura 21 - Estrutura de contração em pod rico em cherte seguido de recristalização de sílica de maior grau de cristalinidade nos espaços abertos. Parte extinta corresponde a hematita que ocorre substituindo o material. XPL, luz transmitida.

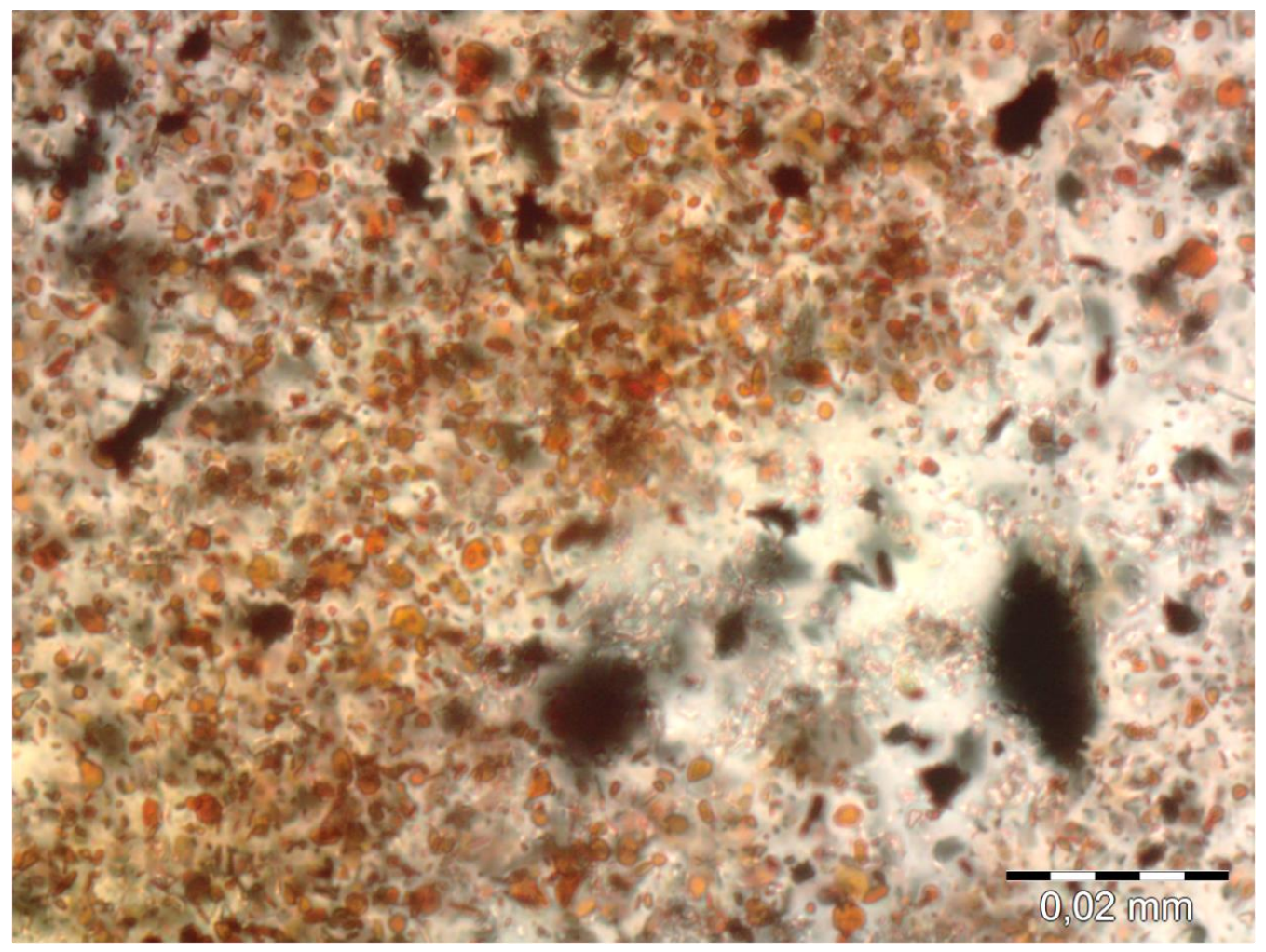

Figura 22 - Micro-grânulos de anquerita (laranja/vermelho) em porção de cherte da formação ferrífera. PPL, Luz transmitida, $40 x$. 
Nos intervalos nodulares e em porções clásticas observa-se que parte dos nódulos jaspilíticos é agrupada, formando uma única estrutura denominada pod. Essas estruturas nas formações ferríferas são formadas por cherte ou jaspe que se juntam devido aos efeitos da compactação e substituição sobre um conjunto de nódulos ou bandas de material inicialmente formado por cherte e níveis clásticos. Em diversos intervalos, encontram-se esferulitos (Fig. 23) formados por sílica criptocristalina pura no interior dos pods. Os esferulitos são compostos de sílica acicular com aspecto radial, que se formam em torno de centro que não é possível de ser diferenciado.

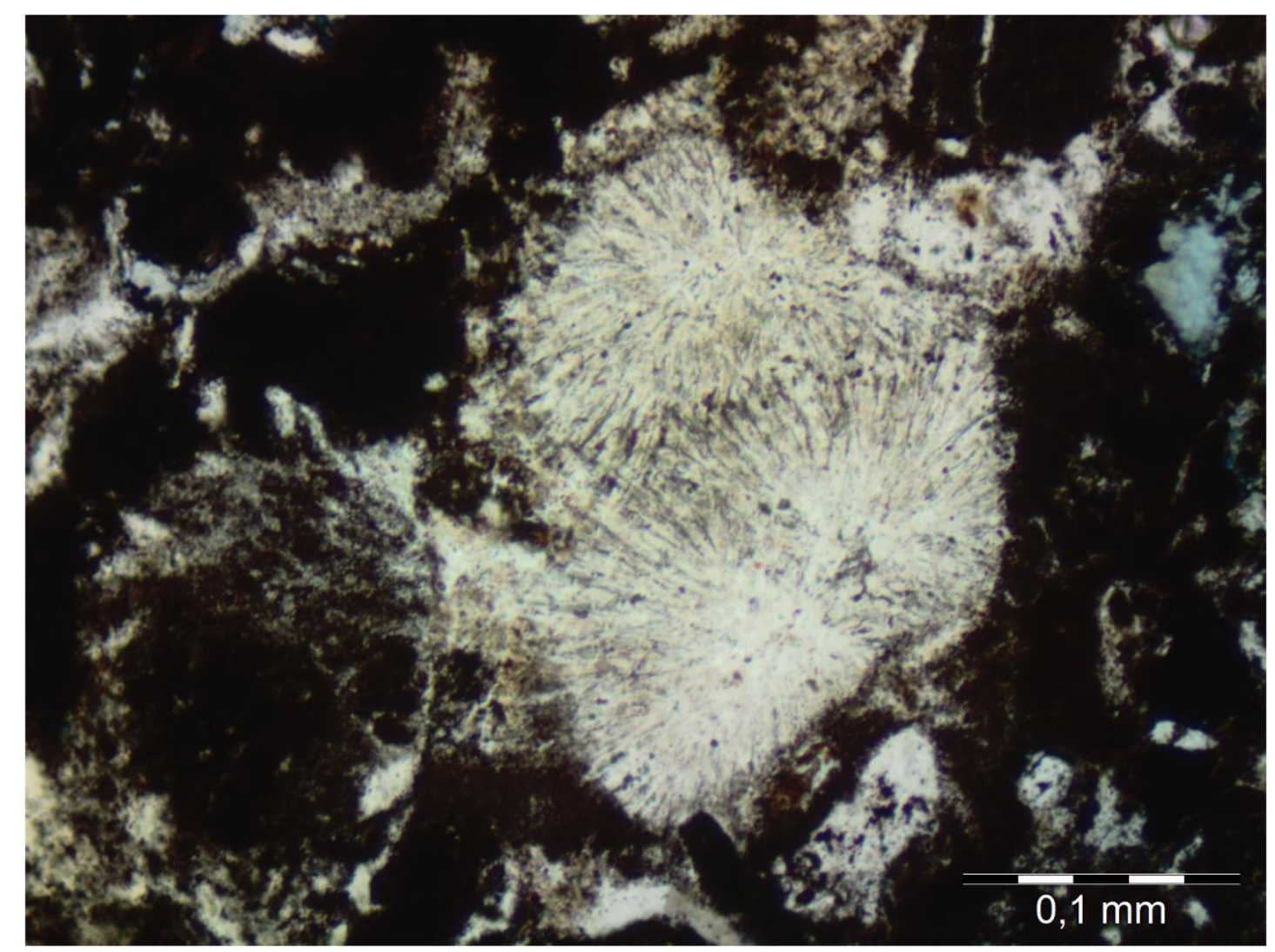

Figura 23 - Esferulitos de sílica finamente cristalizada com hábito radial em amostra de formação ferrífera com níveis clásticos e jaspilíticos. PPL, Luz transmitida.

Próximo aos esferulitos, ocorrem também pseudomorfos de dolomita que estão completamente substituídos por hematita, e em raras ocasiões cristais de dolomita de hábito euédrico em meio a matriz rica em cherte e em carbonato ocorrem nos estratos que ficaram preservados da substituição por hematita (Fig. 24 e 25). 


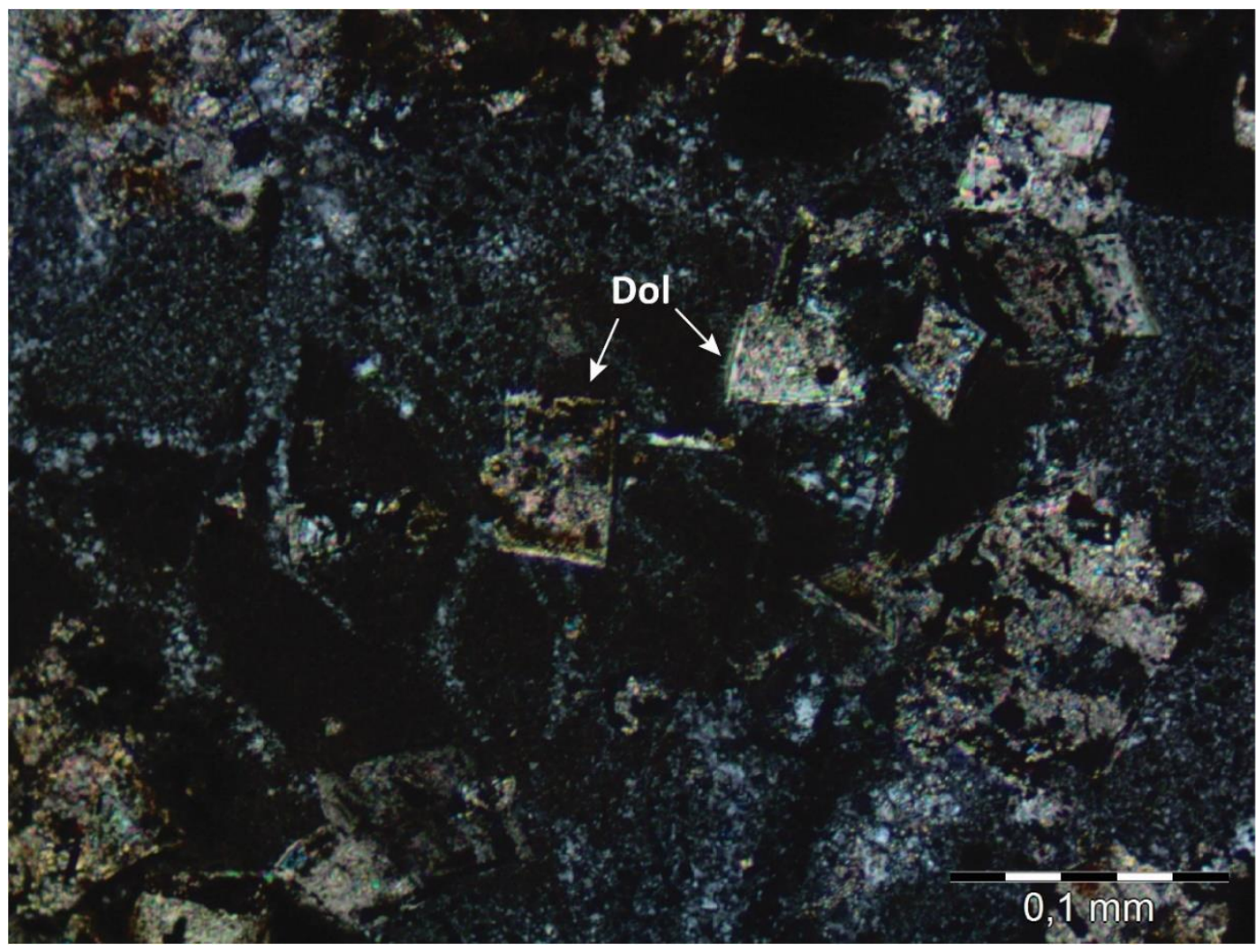

Figura 24 - Cristais de dolomita parcialmente preservados em meio a matriz de cherte e carbonato.

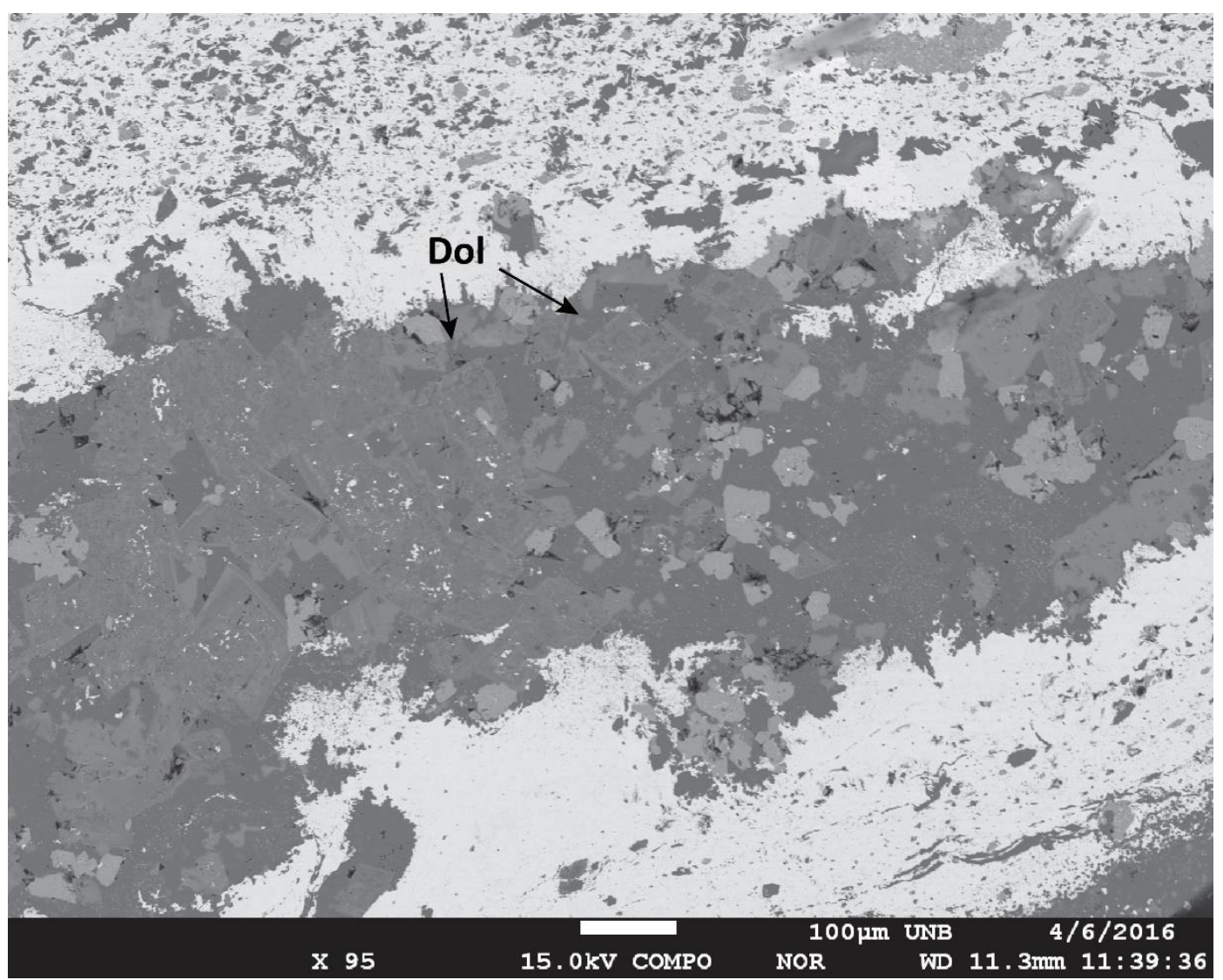

Figura 25 - Pseudomorfos de dolomita substituídos por cherte e matriz substituída por hematítica na parte superior e inferior. Imagem de MEV. 
A matriz entre os nódulos tem aspecto de fluxo pervasivo e afeta as sequências paralelamente à direção do acamamento, em que nódulos e grãos de minerais anteriormente presentes ocorrem substituídos (Fig. 26). As estruturas tardiamente substituídas por hematita especular apresentam cor cinza clara, que as destacam em relação à matriz mais antiga, de cor cinza mais escura. O contato entre os grãos e nódulos de cherte e a matriz hematítica são bruscos, e a hematita existente aparenta substituir progressivamente a borda dessas estruturas.

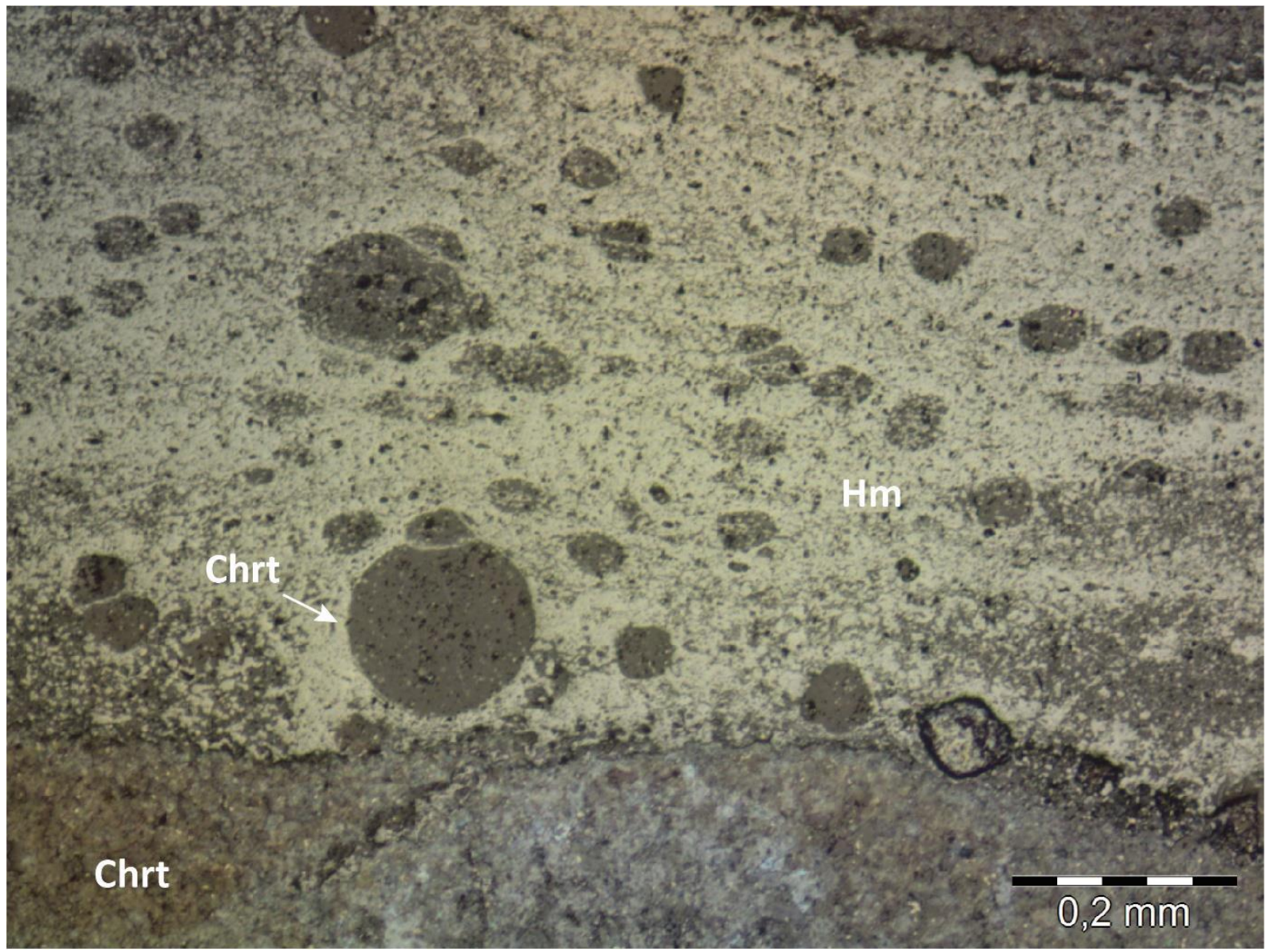

Figura 26 - Matriz hematítica substituindo matriz de cherte. Nódulos de cherte semi preservados ocorrem em meio a matriz. XPL, Luz refletida e transmitida.

A fácies bandada (FFB) da formação ferrífera raramente ocorre com bandamento contínuo e formando grandes espessuras. Os bandamentos observados se distribuem de maneira isolada e intercalados a estratos laminares ou nodulares. Os intervalos onde se forma o bandamento são compostos, em geral, pela alternância entre bandas de hematita especular de cor cinza metálica e bandas de cherte/jaspe de coloração avermelhada. A parte interna das bandas, em certas ocasiões, é composta por nódulos de jaspe e cherte que se agrupam em uma mesma banda. Em outras partes o bandamento mostra-se com textura mais clástica, formado por grãos de minerais e fragmentos de rochas substituídos por cherte e jaspe. A hematita que 
forma as bandas entre as bandas de cherte mostra aspecto maciço ou laminar com grãos de cherte dispersos.

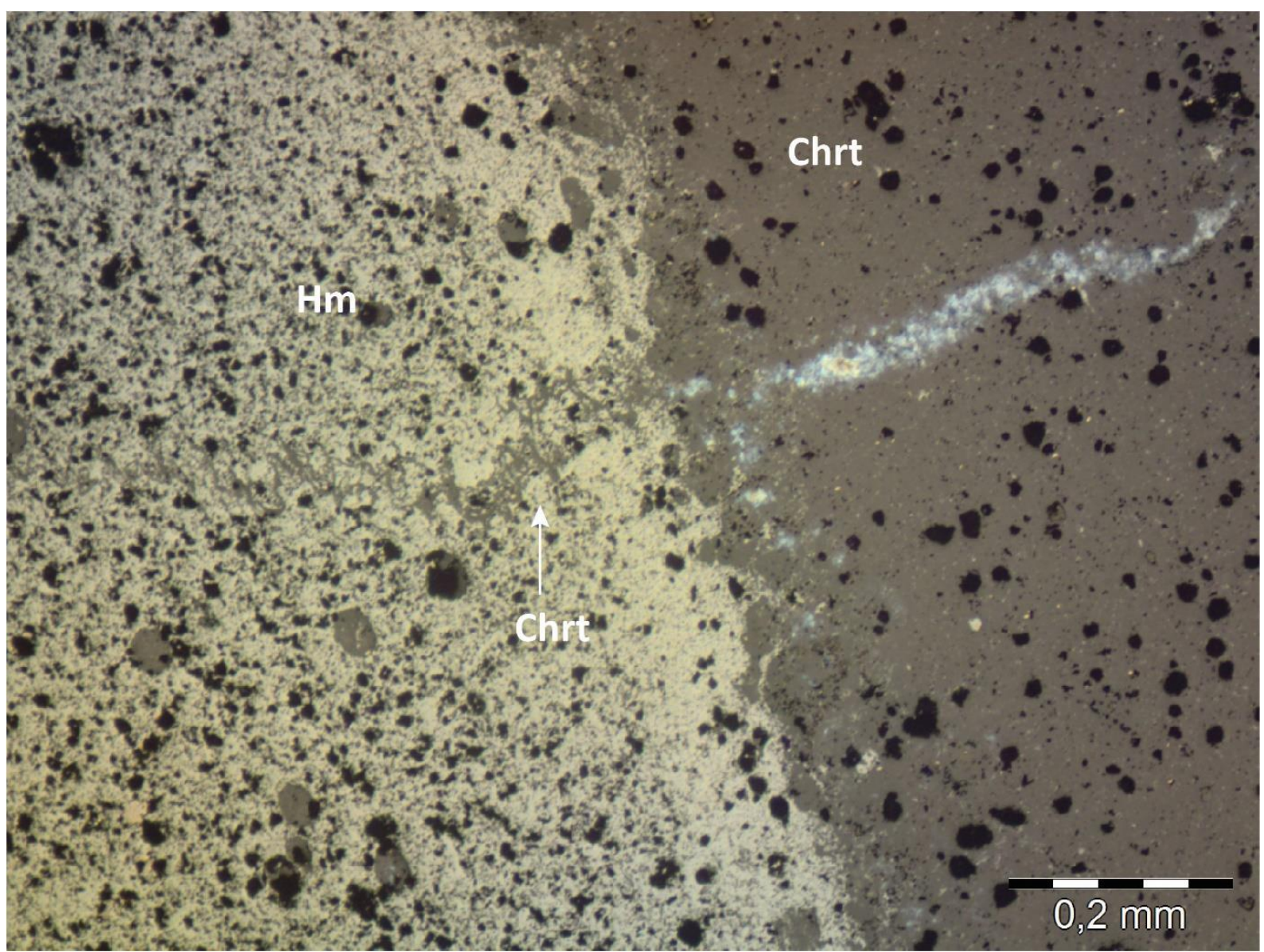

Figura 27 - Contato entre banda rica em hematítica e banda cherteljaspe. Notar veio com comportamento diferenciado entre os dois materiais. XPL, luz refletida e transmitida.

A formação ferrífera laminar (FFL) é interpretada como fácies em que a substituição ocorreu mais rapidamente. Grande parte dos nódulos nesta fácies está estirada ou achatada e ocorre substituída por hematita de brilho metálico, que, em seu estágio final de deformação, forma lâminas delgadas compondo a matriz. As únicas estruturas visíveis nesta fácies são lâminas finas de hematita especular clara em meio a matriz hematítica de cor mais escura. Angerer et al. (2016) chamam a atenção para o fato de que, em estágios iniciais de substituição do cherte/jaspe por hematita, pode ocorrer processo de dissolução dos nódulos paralelamente ao acamamento, denominado "dissolution seam". A fácies laminar aparenta ter sido formada em grande parte por esse processo, aliado a eventos de desfluidização, encurtamento das camadas e consequentemente compactação dos nódulos e veios (Fig. 27).

Macroscopicamente, a matriz hematítica especular formada entre os nódulos, lâminas e bandas de cherte, não mostra estruturação aparente, exceto por alguns níveis laminados e 
nodulares substituídos, que são marcados pela hematita clara e escura. Em lâmina evidencia-se que os níveis de hematita clara são resultado da substituição de nódulos e grãos de minerais que apresentavam composição mais homogênea de cherte ou sílica microcristalina e, por isso, foram substituídos completamente. Os níveis hematíticos mais escuros são resultado da substituição de matriz de composição mais heterogênea e por isso preservam ainda resquícios de cherte/jaspe, conferindo aspecto mais escuro a essa parte.

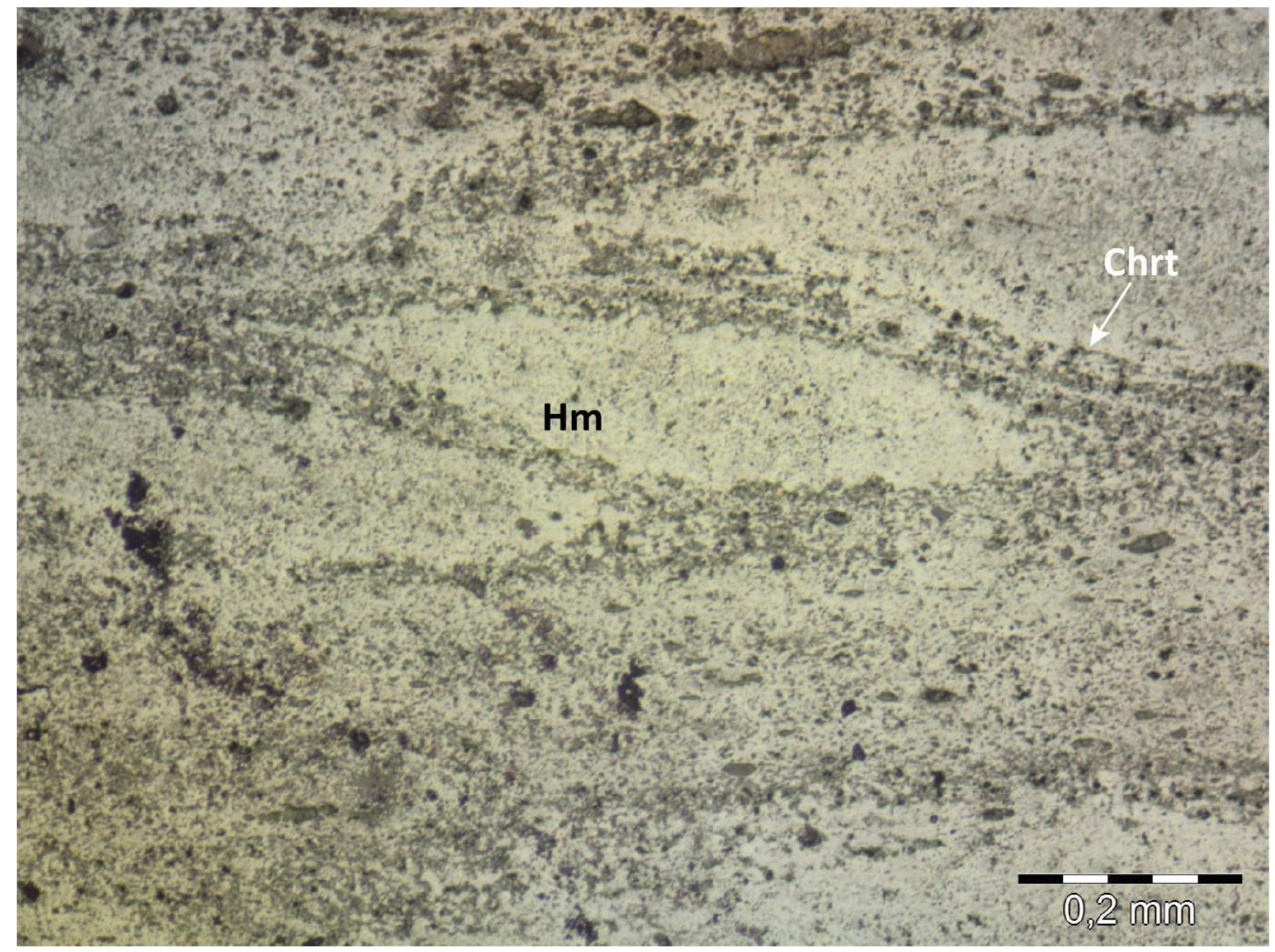

Figura 28 - Formação ferrífera laminar/nodular, nódulos substituídos por hematita e deformados por achatamento. Matriz laminada ocorre entre os nódulos. XPL, Luz refletida e transmitida.

No interior da matriz das porções laminares observa-se que pequenos fragmentos de cherte preservados estão presentes em meio à hematita especular, como mostra a petrografia e análise de MEV (Fig. 28). Resquícios de grãos substituídos por cherte de aspecto mais clástico, alinhados segundo a laminação, estão evidentes em alguns níveis da matriz (Fig. 29). Estes aspectos observados na matriz sugerem que a hematita agora existente na matriz possivelmente substituiu camadas clásticas finas e lâminas de cherte que antes estavam presentes na rocha. 


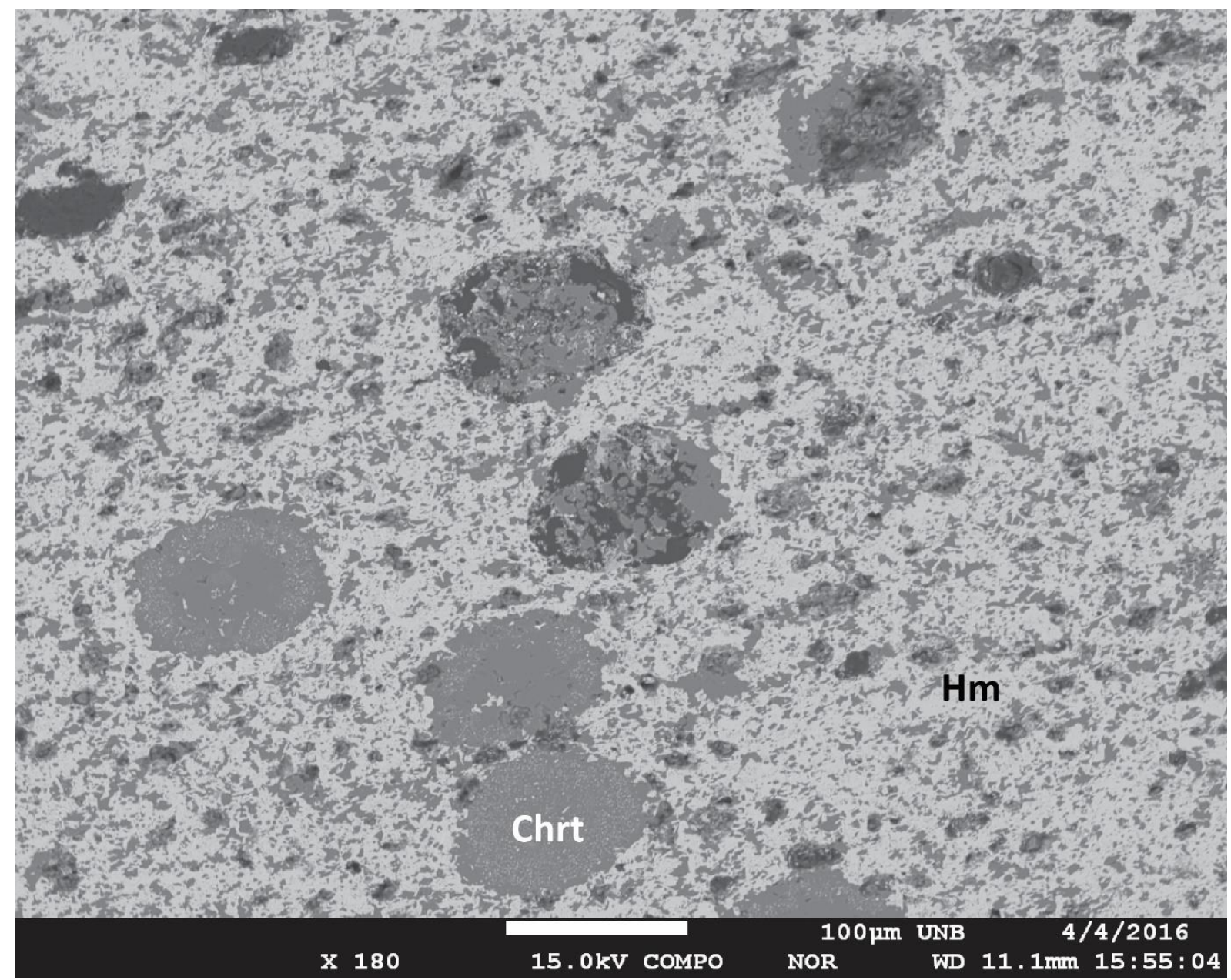

Figura 29 - Grãos substituídos por cherte em meio a matriz hematítica em intervalo laminar de amostra de formação ferrífera bandada. Imagem de MEV.

A fácies de diamictito que, em lâmina, foi analisada em seus intervalos mais finos, corresponde a arenitos imaturos de matriz ferruginosa que transicionam por vezes para arenitos conglomeráticos. Os intervalos conglomeráticos mostram fragmentos líticos de rochas graníticas, calcissilicáticas e carbonáticas e fragmentos menores de quartzo e feldspato imersos em matriz siltosa e arenosa fina, com a presença de óxido de ferro. A matriz dessa rocha apresenta composição quartzosa e carbonática variável resultante, principalmente, da fragmentação dos litoclastos de mármores e granitos. As camadas analisadas de diamictito variam em escala centimétrica a métrica, com lâminas de material mais fino, que ocorrem em intervalos de intercalação de poucos centímetros, e arenitos conglomeráticos e diamictitos grossos que formam camadas que variam de 3 a 8 metros. Em alguns casos camadas clásticas são encontradas em estágio avançado de substituição por hematita, que afeta primeiramente sua matriz e em sequência as bordas dos grãos. 
A formação ferrífera com níveis clásticos representa a fácies em que ocorre a intercalação de lâminas arenosas/siltosas em meio a camadas de formação ferrífera. A rocha normalmente pode ser dividida em porção hematítica, e porção clástica. A porção hematítica corresponde à parte completamente substituída por hematita especular, sendo raramente encontrados grãos diminutos de quartzo ou cherte preservados em meio à matriz hematítica. Os intervalos substituídos mostram finas lâminas de hematita que variam sutilmente de cor, representando possivelmente a substituição de lâminas de sedimentos pretéritos que variavam em granulometria em intervalos laminares, como é visto nas partes preservadas. A porção clástica varia desde intervalos em que a substituição teve início, mas não foi completa, até textura completamente preservada de rocha sedimentar fina. A substituição por hematita nas partes clásticas parece ser influenciada pela granulometria e grau de selecionamento do material, em que as porções de granulometria grossa se mantêm preservadas, enquanto as porções finas e bem selecionadas são mais facilmente substituídas.

A fácies de arenitos ferruginosos mostra graus variados de cimentação de ferro em sua matriz e forma camadas de menor espessura no fim da Formação Santa Cruz, em contato com as rochas da Formação Urucum. As amostras obtidas destes intervalos são caracterizadas pela presença de hematita especular ou óxido de ferro preenchendo a porosidade na matriz, onde grãos preservados e substituídos de minerais, como feldspato, quartzo e mica, ocorrem. As poucas porções preservadas existentes na matriz mostram composição carbonática e quartzosa fina. Os grãos que formam esses arenitos são em geral angulosos e bem selecionados nos intervalos amostrados.

A fácies de formação ferrífera brechada ocorre localmente em algumas camadas da sequência. A rocha apresenta aspecto de material brechado intraformaciolnamente, com matriz substituída por hematita de brilho metálico ou jaspe em locais mais preservados. Em meio à matriz ocorrem fragmentos de minerais e de clastos de material jaspilítico e rico em cherte, possivelmente litoclastos originários de camadas que foram retrabalhadas na bacia. A análise geoquímica de uma dessas fácies mostrou valores muito altos de ferro em relação aos outros intervalos.

As fácies de sedimentos não ferruginosos são formadas por arenitos arcoseanos e brechas arcoseanas da base da sequência e da porção superior do furo UB. As brechas e arenitos que compõem a fácies são imaturos e não ferruginosos. As fácies mostram grãos angulosos que formam intervalos bem selecionados e intervalos de seleção pobre de minerais e fragmentos 
líticos. Entre os grãos de minerais encontrados estão fragmentos de cristais de quartzo, plagioclásio, muscovita e carbonato.

\subsection{Química mineral}

Análises de minerais em microssonda eletrônica foram realizadas em hematita e em cherte presentes nas amostras de formações ferríferas. O principal objetivo foi caracterizar e diferenciar a composição de hematita e cherte presentes em grãos e nódulos substituídos, assim como na matriz existente. Os dados foram arranjados em duas tabelas (Tab. 1,2) em que cada análise foi identificada segundo o tipo de estrutura analisada e a composição química respectiva.

A composição da sílica que ocorre na forma de cherte e sílica microcristalina foi determinada em estruturas de esferulitos, grãos substituídos, matriz de cherte e nódulos com cherte. Os esferulitos mostram composição mais rica em sílica e mais pobre em ferro em comparação a todas as demais formas. Os valores de titânio são inexistentes em quase todas amostras de cherte analisadas, enquanto alumínio mostrou-se levemente enriquecido (média do total de amostras $=0,184 \%$ ). Ferro apresentou valor que cresce do grão (média de 1,621\%), para matriz (média de 2,397\%) e para o nódulo (média de 3,5\%). Os valores baixos de ferro nos grãos certamente estão relacionados a substituição de minerais de grãos de origem clástica que possuíam baixo ferro em sua composição. Potássio se mostrou mais presente nas amostras de grãos e de esferulitos.

Amostras de hematita foram analisadas em grãos substituídos, matriz substituída, matriz de cor clara, matriz de cor escura e matriz dos nódulos substituídos. Os grãos substituídos, que compreendem fragmentos arredondados e minerais de pequena dimensão substituídos por hematita, mostraram composição mais enriquecida em alumínio (média de 0,405 \%) em relação à matriz substituída (média de $0,151 \%$ ). Os valores de ferro para a matriz hematítica são levemente mais altos (média de $88 \%$ ) em comparação aos valores de ferro para os grãos substituídos (média de $81 \%$ ). Os nódulos mostram porcentagens de ferro mais baixas em relação à matriz substituída, e seus valores em alumínio são mais baixos em comparação com os valores dos grãos. Análises feitas na matriz clara e na matriz escura mostram que a mais clara contém menor quantidade de alumínio, titânio e sílica em relação à mais escura. 
Tabela 1 - Dados de microssonda sobre amostras de cherte em estruturas das porções não ferruginosas das formações ferríferas.

\begin{tabular}{|c|c|c|c|c|c|c|c|c|c|c|c|c|c|}
\hline & \multirow[t]{2}{*}{ Amostra } & \multicolumn{5}{|c|}{ Peso percentual (\% p/p) } & \multicolumn{7}{|c|}{ Átomos por unidade de fórmula, na base de 20} \\
\hline & & $\mathrm{Al}_{2} \mathrm{O}_{3}$ & FeO* & MnO & $\mathrm{K}_{2} \mathrm{O}$ & $\mathrm{SiO}_{2}$ & Total & Al & $\mathrm{Fe}^{+2 *}$ & Mn & $\mathbf{K}$ & Si & Total \\
\hline 1 & Esferulito Cherte & 0.65 & 0.28 & 0.08 & 0.26 & 97.88 & 99.15 & 0.008 & 0.002 & 0.001 & 0.003 & 0.991 & 1.006 \\
\hline 2 & Esferulito Cherte & 0.26 & 0.35 & 0.05 & 0.05 & 97.99 & 98.71 & 0.003 & 0.003 & 0.000 & 0.001 & 0.995 & 1.003 \\
\hline 3 & Esferulito Cherte & 0.00 & 0.06 & 0.04 & 0.04 & 99.68 & 99.85 & 0.000 & 0.001 & 0.000 & 0.000 & 0.998 & 1.000 \\
\hline 4 & Esferulito Cherte & 0.13 & 0.07 & 0.00 & 0.04 & 99.34 & 99.62 & 0.002 & 0.001 & 0.000 & 0.001 & 0.998 & 1.001 \\
\hline 5 & Esferulito Cherte & 0.04 & 0.09 & 0.00 & 0.02 & 99.21 & 99.35 & 0.000 & 0.001 & 0.000 & 0.000 & 0.999 & 1.001 \\
\hline 6 & Grão Cherte & 0.00 & 0.02 & 0.05 & 0.01 & 98.33 & 98.41 & 0.000 & 0.000 & 0.000 & 0.000 & 1.000 & 1.000 \\
\hline 7 & Grão Cherte & 0.00 & 0.92 & 0.01 & 0.01 & 99.29 & 100.23 & 0.000 & 0.008 & 0.000 & 0.000 & 0.996 & 1.003 \\
\hline 8 & Grão Cherte & 0.82 & 4.82 & 0.00 & 0.21 & 87.06 & 92.91 & 0.011 & 0.045 & 0.000 & 0.003 & 0.968 & 1.026 \\
\hline 9 & Grão Cherte & 0.71 & 1.45 & 0.03 & 0.21 & 92.54 & 95.05 & 0.009 & 0.013 & 0.000 & 0.003 & 0.985 & 1.010 \\
\hline 10 & Grão Cherte & 0.11 & 0.91 & 0.00 & 0.00 & 98.17 & 99.18 & 0.001 & 0.008 & 0.000 & 0.000 & 0.995 & 1.004 \\
\hline 11 & Matriz Cherte & 0.01 & 5.47 & 0.04 & 0.03 & 89.87 & 95.43 & 0.000 & 0.050 & 0.000 & 0.000 & 0.973 & 1.023 \\
\hline 12 & Matriz Cherte & 0.61 & 0.53 & 0.00 & 0.06 & 97.24 & 98.46 & 0.007 & 0.005 & 0.000 & 0.001 & 0.991 & 1.003 \\
\hline 13 & Matriz Cherte & 0.05 & 0.07 & 0.00 & 0.03 & 99.55 & 99.71 & 0.001 & 0.001 & 0.000 & 0.000 & 0.999 & 1.001 \\
\hline 14 & Matriz Cherte & 0.16 & 5.80 & 0.00 & 0.01 & 92.34 & 98.41 & 0.002 & 0.051 & 0.000 & 0.000 & 0.971 & 1.024 \\
\hline 15 & Matriz Cherte & 0.03 & 0.12 & 0.04 & 0.00 & 100.54 & 100.72 & 0.000 & 0.001 & 0.000 & 0.000 & 0.999 & 1.000 \\
\hline 16 & Nódulo Cherte & 0.04 & 11.17 & 0.05 & 0.05 & 85.24 & 96.66 & 0.001 & 0.104 & 0.001 & 0.001 & 0.946 & 1.052 \\
\hline 17 & Nódulo Cherte & 0.00 & 2.90 & 0.15 & 0.00 & 94.69 & 97.79 & 0.000 & 0.025 & 0.001 & 0.000 & 0.986 & 1.013 \\
\hline 18 & Nódulo Cherte & 0.07 & 2.72 & 0.05 & 0.01 & 95.63 & 98.65 & 0.001 & 0.023 & 0.000 & 0.000 & 0.986 & 1.011 \\
\hline 19 & Nódulo Cherte & 0.00 & 0.49 & 0.00 & 0.00 & 98.70 & 99.36 & 0.000 & 0.004 & 0.000 & 0.000 & 0.997 & 1.001 \\
\hline 20 & Nódulo Cherte & 0.01 & 0.25 & 0.00 & 0.01 & 100.22 & 100.62 & 0.000 & 0.002 & 0.000 & 0.000 & 0.998 & 1.000 \\
\hline
\end{tabular}


Tabela 2 - Dados de microssonda sobre hematita que ocorre substituindo estruturas nas formações ferríferas.

\begin{tabular}{|c|c|c|c|c|c|c|c|c|c|c|c|c|c|c|c|c|c|c|c|c|}
\hline \multirow{2}{*}{\multicolumn{2}{|c|}{ Amostra }} & \multicolumn{9}{|c|}{ Peso percentual (\% p/p) } & \multicolumn{10}{|c|}{ Átomos por unidade de fórmula, na base de 30} \\
\hline & & $\mathrm{SiO}_{2}$ & $\mathrm{TiO}_{2}$ & $\mathrm{Al}_{2} \mathrm{O}_{3}$ & FeO* & MnO & MgO & $\mathbf{K}_{2} \mathbf{O}$ & $\mathbf{F}$ & Total & $\mathbf{S i}$ & $\mathbf{T i}$ & Al & $\mathrm{Fe}^{+3}$ & $\mathrm{Fe}^{+2}$ & Mn & Mg & $\mathbf{K}$ & $\mathbf{F}$ & Total \\
\hline 1 & Grão Hm & 0.57 & 0.00 & 0.29 & 87.29 & 0.00 & 0.00 & 0.01 & 0.39 & 88.54 & 0.015 & 0.000 & 0.009 & 1.935 & 0.000 & 0.000 & 0.000 & 0.000 & 0.033 & 1.992 \\
\hline 2 & Grão Hm & 0.45 & 0.00 & 0.28 & 87.11 & 0.00 & 0.01 & 0.00 & 0.29 & 88.13 & 0.012 & 0.000 & 0.009 & 1.944 & 0.000 & 0.000 & 0.000 & 0.000 & 0.024 & 1.989 \\
\hline 3 & Grão Hm & 0.76 & 0.02 & 0.47 & 84.74 & 0.00 & 0.02 & 0.01 & 0.29 & 86.32 & 0.022 & 0.000 & 0.016 & 1.978 & 0.060 & 0.000 & 0.001 & 0.001 & 0.027 & 2.104 \\
\hline 4 & Grão Hm & 1.12 & 0.20 & 0.60 & 83.94 & 0.00 & 0.00 & 0.07 & 0.28 & 86.21 & 0.031 & 0.004 & 0.019 & 1.913 & 0.004 & 0.000 & 0.000 & 0.003 & 0.024 & 1.997 \\
\hline 5 & Grão Hm & 4.72 & 0.00 & 0.04 & 83.36 & 0.00 & 0.00 & 0.00 & 0.26 & 88.38 & 0.125 & 0.000 & 0.001 & 1.753 & 0.088 & 0.000 & 0.000 & 0.000 & 0.022 & 1.990 \\
\hline 6 & Grão Hm & 0.86 & 0.31 & 0.83 & 82.64 & 0.09 & 0.06 & 0.05 & 0.24 & 85.07 & 0.024 & 0.006 & 0.027 & 1.911 & 0.000 & 0.002 & 0.003 & 0.002 & 0.021 & 1.995 \\
\hline 7 & Grão Hm & 0.81 & 0.00 & 0.78 & 81.82 & 0.00 & 0.00 & 0.02 & 0.22 & 83.64 & 0.023 & 0.000 & 0.026 & 1.923 & 0.000 & 0.000 & 0.000 & 0.001 & 0.019 & 1.992 \\
\hline 8 & Grão Hm & 0.40 & 0.00 & 0.46 & 79.65 & 0.07 & 0.04 & 0.05 & 0.23 & 80.92 & 0.012 & 0.000 & 0.016 & 1.933 & 0.000 & 0.002 & 0.002 & 0.002 & 0.021 & 1.988 \\
\hline 9 & Grão Hm & 1.62 & 0.00 & 0.10 & 72.44 & 0.04 & 0.34 & 0.02 & 0.17 & 74.72 & 0.051 & 0.000 & 0.004 & 1.898 & 0.005 & 0.001 & 0.016 & 0.001 & 0.017 & 1.991 \\
\hline 10 & Grão Hm & 1.85 & 0.04 & 0.20 & 71.19 & 0.00 & 0.60 & 0.02 & 0.15 & 74.04 & 0.058 & 0.001 & 0.008 & 1.875 & 0.011 & 0.000 & 0.028 & 0.001 & 0.015 & 1.997 \\
\hline 11 & Matriz Hm & 0.31 & 0.12 & 0.17 & 89.13 & 0.09 & 0.05 & 0.04 & 0.31 & 90.22 & 0.008 & 0.002 & 0.005 & 1.943 & 0.000 & 0.002 & 0.002 & 0.001 & 0.026 & 1.989 \\
\hline 12 & Matriz Hm & 0.60 & 0.00 & 0.22 & 88.77 & 0.00 & 0.00 & 0.00 & 0.29 & 89.88 & 0.016 & 0.000 & 0.007 & 1.946 & 0.000 & 0.000 & 0.000 & 0.000 & 0.024 & 1.992 \\
\hline 13 & Matriz Hm & 0.54 & 0.00 & 0.09 & 88.76 & 0.08 & 0.02 & 0.00 & 0.33 & 89.79 & 0.014 & 0.000 & 0.003 & 1.948 & 0.000 & 0.002 & 0.001 & 0.000 & 0.027 & 1.994 \\
\hline 14 & Matriz Hm & 0.43 & 0.00 & 0.07 & 88.65 & 0.00 & 0.00 & 0.02 & 0.31 & 89.48 & 0.011 & 0.000 & 0.002 & 1.946 & 0.000 & 0.000 & 0.000 & 0.001 & 0.025 & 1.986 \\
\hline 15 & Matriz Hm & 0.51 & 0.28 & 0.06 & 88.60 & 0.00 & 0.02 & 0.00 & 0.26 & 89.73 & 0.014 & 0.006 & 0.002 & 1.950 & 0.000 & 0.000 & 0.001 & 0.000 & 0.022 & 1.994 \\
\hline 17 & Matriz Hm & 1.13 & 0.00 & 0.04 & 88.44 & 0.01 & 0.00 & 0.01 & 0.27 & 89.90 & 0.030 & 0.000 & 0.001 & 1.937 & 0.000 & 0.000 & 0.000 & 0.000 & 0.023 & 1.991 \\
\hline 18 & Matriz Hm & 0.42 & 0.03 & 0.07 & 88.38 & 0.10 & 0.00 & 0.01 & 0.26 & 89.26 & 0.011 & 0.001 & 0.002 & 1.953 & 0.000 & 0.002 & 0.000 & 0.000 & 0.022 & 1.991 \\
\hline 19 & Matriz Hm & 0.36 & 0.17 & 0.38 & 88.30 & 0.00 & 0.02 & 0.06 & 0.23 & 89.53 & 0.009 & 0.003 & 0.012 & 1.951 & 0.000 & 0.000 & 0.001 & 0.002 & 0.019 & 1.998 \\
\hline 20 & Matriz Hm & 0.47 & 0.32 & 0.28 & 88.22 & 0.01 & 0.02 & 0.01 & 0.29 & 89.61 & 0.012 & 0.006 & 0.009 & 1.941 & 0.000 & 0.000 & 0.001 & 0.000 & 0.024 & 1.994 \\
\hline 21 & Matriz Hm Clara & 0.71 & 0.30 & 0.50 & 87.53 & 0.00 & 0.01 & 0.03 & 0.34 & 89.43 & 0.019 & 0.006 & 0.015 & 1.926 & 0.000 & 0.000 & 0.000 & 0.001 & 0.028 & 1.996 \\
\hline 22 & Matriz Hm Clara & 0.79 & 0.43 & 0.40 & 87.23 & 0.00 & 0.00 & 0.05 & 0.23 & 89.14 & 0.021 & 0.009 & 0.013 & 1.930 & 0.004 & 0.000 & 0.000 & 0.002 & 0.020 & 1.997 \\
\hline 23 & Matriz Hm Clara & 0.65 & 0.33 & 0.41 & 86.67 & 0.07 & 0.05 & 0.01 & 0.25 & 88.44 & 0.017 & 0.007 & 0.013 & 1.935 & 0.000 & 0.001 & 0.002 & 0.000 & 0.021 & 1.997 \\
\hline 24 & Matriz Hm Escura & 0.97 & 0.38 & 0.81 & 85.93 & 0.00 & 0.00 & 0.00 & 0.33 & 88.41 & 0.026 & 0.008 & 0.025 & 1.908 & 0.003 & 0.000 & 0.000 & 0.000 & 0.027 & 1.997 \\
\hline 25 & Nódulo Hm & 0.25 & 0.09 & 0.15 & 88.13 & 0.00 & 0.01 & 0.00 & 0.34 & 88.96 & 0.007 & 0.002 & 0.005 & 1.951 & 0.000 & 0.000 & 0.000 & 0.000 & 0.029 & 1.993 \\
\hline 26 & Nódulo Hm & 0.34 & 0.22 & 0.25 & 87.38 & 0.04 & 0.00 & 0.02 & 0.33 & 88.57 & 0.009 & 0.004 & 0.008 & 1.938 & 0.000 & 0.001 & 0.000 & 0.001 & 0.028 & 1.988 \\
\hline 27 & Nódulo Hm & 1.35 & 0.11 & 0.08 & 85.93 & 0.03 & 0.01 & 0.00 & 0.25 & 87.77 & 0.036 & 0.002 & 0.002 & 1.920 & 0.007 & 0.001 & 0.000 & 0.000 & 0.021 & 1.990 \\
\hline 28 & Nódulo Hm & 0.17 & 0.06 & 0.12 & 85.60 & 0.00 & 0.26 & 0.00 & 0.30 & 86.52 & 0.005 & 0.001 & 0.004 & 1.929 & 0.000 & 0.000 & 0.011 & 0.000 & 0.026 & 1.975 \\
\hline 29 & Nódulo Hm & 0.20 & 0.04 & 0.51 & 85.44 & 0.04 & 0.23 & 0.00 & 0.29 & 86.74 & 0.005 & 0.001 & 0.016 & 1.914 & 0.000 & 0.001 & 0.009 & 0.000 & 0.024 & 1.971 \\
\hline 30 & Nódulo Hm & 0.35 & 0.00 & 0.12 & 73.97 & 0.06 & 0.33 & 0.04 & 0.20 & 75.07 & 0.010 & 0.000 & 0.004 & 1.779 & 0.000 & 0.002 & 0.014 & 0.002 & 0.018 & 1.828 \\
\hline
\end{tabular}




\subsection{Litogeoquímica}

As formações ferríferas têm sido amplamente utilizadas como representantes químicas da água do mar em que foram precipitadas (Bekker et al., 2010; Angerer et al., 2016). A geoquímica de elementos maiores e elementos menores é ferramenta que ajuda a obter valiosas informações sobre o contexto de deposição das formações ferríferas, mostrando as principais áreas fontes que estavam contribuindo com sedimentos para a bacia, assim como as assinaturas das águas ou de fumarolas que estavam presentes (Bau \& Dulski, 1996).

Trabalhos anteriores sobre as rochas da morraria do Rabicho e do Urucum dividiram estas geoquímicamente em 3 grupos: sedimentos ricos em alumínio, sedimentos ricos em ferro e sedimentos ricos em manganês (Viehmann et al., 2016). As 24 amostras de formações ferríferas e sedimentos foram analisadas geoquímicamente e petrograficamente e possibilitaram separar 3 grupos com características distintas, diferenciando-se somente pela ausência do grupo rico em manganês e pela presença do grupo de arenitos arcoseano (Tab. 3).

O primeiro grupo definido como "formações ferríferas puras" (Pure Iron Formation IF) é composto por 10 amostras que se caracterizam por apresentar níveis nodulares ou laminares em pequena quantidade, granulometria fina ou maciça, e mineralogia essencialmente composta por sílica microcristalina (cherte ou jaspe) e hematita. Essas rochas mostram valores baixos de $\mathrm{TiO}_{2}$ (<0,03 wt.\%), $\mathrm{Al}_{2} \mathrm{O}_{3}(<0.36$ wt.\%), $\mathrm{Zr}(<12$ wt. $\%)$ e $\mathrm{Th}(<0.5$ wt $\%)$.

O segundo grupo descrito como "formações ferríferas com contribuições clásticas" (Clastic Iron Formation - CIF) é formado por 9 amostras. As formações ferríferas clásticas têm como principais feições a presença de lâminas de material clástico fino rico em ferro, composto de fragmentos milimétricos $(<0.5 \mathrm{~cm})$ retrabalhados da própria formação ferrífera. Texturalmente esse grupo representa rochas depositadas ou afetadas por regimes de maior energia nos locais onde havia aporte restrito de sedimentos clásticos finos durante a sedimentação química prevalecente. A geoquímica deste grupo difere, principalmente, pelos valores de $\mathrm{TiO}_{2}$ acima de $0,1 \mathrm{wt} \%$ e pelos valores de $\mathrm{Al}_{2} \mathrm{O}_{3}$ acima de 1,22 wt $\%$.

O terceiro grupo individualizado foi o de "arenitos arcoseanos" (Arkosean Sandstones - AS), do qual foram investigadas 5 amostras. O grupo é representado por arenitos médios a grossos que possuem fragmentos líticos de variados tipos de rochas e que se diferenciam pela ausência de ferro em sua composição. Além dos valores baixos de ferro, valores altos de $\mathrm{Al}_{2} \mathrm{O}_{3}$, $\mathrm{TiO}_{2}$ e $\mathrm{SiO}_{2}$ são observados comparativamente às formações ferríferas. 
Tabela 3 - Valores de elementos maiores em peso percentual de óxidos para as amostras analisadas de formações ferríferas, formações ferríferas clásticas e arenitos arcoseanos.

\begin{tabular}{|c|c|c|c|c|c|c|c|c|c|c|c|c|}
\hline \multirow[t]{2}{*}{ Amostra } & \multirow[t]{2}{*}{ Tipo } & \multicolumn{11}{|c|}{ Peso percentual $(\%$ p/p) } \\
\hline & & $\mathrm{SiO}_{2}$ & $\mathrm{TiO}_{2}$ & $\mathrm{Al}_{2} \mathrm{O}_{3}$ & $\mathrm{Fe}_{2} \mathrm{O}_{3}$ & MnO & MgO & $\mathrm{CaO}$ & $\mathrm{Na}_{2} \mathrm{O}$ & $\mathrm{K}_{2} \mathrm{O}$ & $\mathbf{P}_{2} \mathrm{O}_{5}$ & LOI \\
\hline SC-02 & CIF & 24.22 & 0.14 & 2.31 & 71.25 & 0.15 & 0.04 & 0.03 & 0.02 & 0.59 & 0.09 & 1.0 \\
\hline SC-07 & CIF & 32.36 & 0.32 & 4.05 & 48.27 & 5.73 & 1.08 & 1.94 & 1.21 & 1.15 & 0.16 & 3.6 \\
\hline SC-08 & CIF & 26.76 & 0.17 & 2.54 & 43.99 & 2.97 & 4.16 & 7.23 & 0.73 & 0.69 & 0.29 & 10.3 \\
\hline MG-04 & CIF & 10.61 & 0.10 & 1.22 & 20.12 & 0.38 & 9.87 & 22.34 & 0.65 & 0.33 & 0.19 & 33.5 \\
\hline MG-05 & CIF & 23.09 & 0.13 & 1.75 & 49.90 & 2.57 & 1.89 & 8.95 & 0.07 & 0.39 & 0.36 & 10.7 \\
\hline MG-06 & CIF & 20.23 & 0.11 & 2.19 & 45.38 & 2.53 & 4.39 & 10.04 & 0.03 & 0.48 & 0.47 & 14.0 \\
\hline MG-07 & CIF & 38.11 & 0.21 & 6.29 & 24.08 & 2.55 & 4.82 & 8.42 & 0.04 & 1.48 & 0.15 & 13.6 \\
\hline UB-04 & CIF & 19.30 & 0.20 & 2.62 & 71.14 & 0.03 & 0.66 & 2.49 & 0.22 & 0.44 & 1.29 & 1.5 \\
\hline UB-06 & $\mathrm{CIF}$ & 43.43 & 0.19 & 4.09 & 35.02 & 0.14 & 1.27 & 6.51 & 0.41 & 0.91 & 0.47 & 7.4 \\
\hline SC-01 & IF & 58.11 & 0.02 & 0.11 & 41.29 & $<0.01$ & $<0.01$ & $<0.01$ & $<0.01$ & $<0.01$ & 0.06 & 0.3 \\
\hline SC-03 & IF & 52.81 & 0.03 & 0.28 & 45.59 & 0.14 & $<0.01$ & 0.20 & 0.01 & 0.02 & 0.11 & 0.7 \\
\hline SC-04 & IF & 47.56 & 0.03 & 0.31 & 47.03 & 0.25 & 0.25 & 1.87 & 0.04 & 0.08 & 0.72 & 1.7 \\
\hline SC-05 & IF & 15.37 & 0.03 & 0.09 & 81.23 & 0.05 & 0.01 & 1.70 & 0.02 & $<0.01$ & 0.48 & 0.8 \\
\hline SC-06 & IF & 24.24 & 0.03 & 0.07 & 68.71 & 0.18 & 0.18 & 3.48 & 0.02 & $<0.01$ & 0.61 & 2.3 \\
\hline MG-01 & IF & 32.13 & 0.02 & 0.11 & 67.00 & 0.03 & $<0.01$ & 0.07 & 0.01 & $<0.01$ & 0.05 & 0.5 \\
\hline MG-02 & IF & 16.22 & 0.02 & 0.05 & 63.25 & 0.32 & 2.91 & 7.21 & 0.02 & $<0.01$ & 0.36 & 9.5 \\
\hline UB-02 & IF & 36.01 & 0.03 & 0.36 & 60.24 & 0.09 & 0.07 & 0.25 & 0.01 & 0.01 & 0.56 & 2.3 \\
\hline UB-07 & IF & 24.54 & 0.02 & 0.06 & 63.03 & 0.05 & 0.16 & 6.31 & 0.01 & $<0.01$ & 0.30 & 5.4 \\
\hline MG-03 & IF & 17.41 & 0.02 & 0.18 & 35.97 & 0.29 & 6.27 & 16.63 & 0.04 & $<0.01$ & 0.42 & 22.6 \\
\hline SC-09 & AS & 59.59 & 0.18 & 6.66 & 13.83 & 3.82 & 2.14 & 3.72 & 1.92 & 2.08 & 0.11 & 5.6 \\
\hline SC-10 & AS & 69.62 & 0.29 & 8.14 & 2.16 & 0.27 & 3.10 & 4.62 & 1.54 & 2.73 & 0.07 & 7.3 \\
\hline UB-01 & AS & 61.28 & 0.68 & 9.98 & 12.95 & 0.05 & 2.45 & 0.46 & 0.47 & 3.07 & 0.08 & 8.3 \\
\hline UB-03 & AS & 60.77 & 0.30 & 10.02 & 4.58 & 0.09 & 3.13 & 5.85 & 1.97 & 3.01 & 0.08 & 9.8 \\
\hline UB-05 & AS & 56.82 & 0.45 & 11.58 & 6.24 & 0.08 & 4.86 & 5.83 & 2.47 & 1.94 & 0.11 & 9.3 \\
\hline
\end{tabular}




\subsubsection{Elementos Maiores}

As análises de dados geoquímicos de elementos maiores têm sido geralmente utilizadas para ajudar a discernir a influência continental ou hidrotermal entre depósitos sedimentares (Cox et al., 2013). Os elementos maiores das amostras analisadas foram correlacionados, utilizando o coeficiente de correlação de Pearson (Tab. 4, 5, 6).

Pearson Correlation Coefficients for IF ( $\mathrm{n}=10)$

$\begin{array}{ccccccccccccc} & \mathrm{SiO}_{2} & \mathrm{TiO}_{2} & \mathrm{Al}_{2} \mathrm{O}_{3} & \mathrm{Fe}_{2} \mathrm{O}_{3} & \mathrm{MnO} & \mathrm{MgO} & \mathrm{CaO} & \mathrm{Na}_{2} \mathrm{O} & \mathrm{K}_{2} \mathrm{O} & \mathrm{P}_{2} \mathrm{O}_{5} & \text { LOI } \\ \mathrm{SiO}_{2} & 1.00 & 0.18 & 0.52 & -0.56 & -0.11 & -0.45 & -0.57 & -0.12 & 0.34 & -0.33 & -0.52 \\ \mathrm{TiO}_{2} & & 1.00 & 0.55 & 0.24 & -0.15 & -0.67 & -0.60 & 0.00 & 0.34 & 0.58 & -0.46 \\ \mathrm{Al}_{2} \mathrm{O}_{3} & & & 1.00 & -0.44 & 0.06 & -0.10 & -0.29 & 0.15 & -0.27 & 0.29 & -0.10 \\ \mathrm{Fe}_{2} \mathrm{O}_{3} & & & & 1.00 & -0.57 & -0.67 & -0.48 & -0.51 & -0.54 & 0.19 & -0.42 \\ \mathrm{MnO} & & & & & 1.00 & 0.69 & 0.60 & 0.71 & 0.98 & 0.36 & 0.62 \\ \mathrm{MgO} & & & & & & 1.00 & 0.94 & 0.56 & 1.00 & -0.38 & 0.98 \\ \mathrm{CaO} & & & & & & & 1.00 & 0.58 & 0.99 & 0.08 & 0.98 \\ \mathrm{Na}_{2} \mathrm{O} & & & & & & & & 1.00 & 0.99 & 0.58 & 0.56 \\ \mathrm{~K}_{2} \mathrm{O} & & & & & & & & & 1.00 & 0.60 & 0.01 \\ \mathrm{P}_{2} \mathrm{O}_{5} & & & & & & & & & & 1.00 & 0.14\end{array}$

Tabela 4 - Coeficientes de correlação de Pearson para formações ferríferas "puras". Valores positivos que se aproximam de 1 (verde) representam correlações positivas, enquanto valores negativos próximos de -1 (vermelho) representam correlações inversamente proporcionais.

A fácies geoquímica definida como formação ferrífera pura (Iron Formation - IF) mostrou maior pureza quanto a contribuição clástica. A correlação dos elementos maiores das amostras dessa fácies mostrou níveis de significância muito bons $(\mathrm{P}<0.01)$ para as correlações entre $\mathrm{CaO}$ x $\mathrm{MgO}$ (positiva forte), $\mathrm{K}_{2} \mathrm{O}$ x $\mathrm{MnO}$ (positiva), $\mathrm{K}_{2} \mathrm{O}$ x $\mathrm{CaO}$ (positiva) e valores de correlação bons $(\mathrm{P}<0.05)$ para $\mathrm{Na}_{2} \mathrm{O} \times \mathrm{MnO}$ (positiva forte), $\mathrm{MgO} \times \mathrm{MnO}$ (positiva forte), $\mathrm{MgO}$ × $\mathrm{Fe}_{2} \mathrm{O}_{3}$ (negativa), $\mathrm{MgO}$ x $\mathrm{TiO}_{2}$ (negativa). Análises de correlação de grau de significância menores, mas ainda bons $(\mathrm{P}<0.1)$, mostram correlações negativas de $\mathrm{Fe}_{2} \mathrm{O}_{3}$ com $\mathrm{SiO}_{2}$ e $\mathrm{MnO}$, e positivas de $\mathrm{TiO}_{2} \times \mathrm{Al}_{2} \mathrm{O}_{3}$.

A correlação de positiva de $\mathrm{CaO}$ e $\mathrm{MgO}$ está associada provavelmente à formação de carbonato dolomítico como o evidenciado na petrografia. A correlação positiva de $\mathrm{MnO}$ com $\mathrm{CaO}$ e $\mathrm{MgO}$ possivelmente é resultado da presença de anquerita identificada na petrografia, a correlação positiva com $\mathrm{K}_{2} \mathrm{O}$ possivelmente está associada a presença de mineral de manganês (criptomelano). A correlação negativa de $\mathrm{CaO}$ com $\mathrm{Fe}_{2} \mathrm{O}_{3}, \mathrm{TiO}_{2}$ e $\mathrm{Al}_{2} \mathrm{O}_{3}$ demonstra que o mecanismo para fornecimento nestas rochas é distinto dos mecanismos que munem a rocha com $\mathrm{Fe}_{2} \mathrm{O}_{3}$, $\mathrm{TiO}_{2}$ e $\mathrm{Al}_{2} \mathrm{O}_{3}$ (Cox et al., 2013). Correlações positivas de $\mathrm{TiO}_{2}$ e $\mathrm{Al}_{2} \mathrm{O}_{3}$ implicam em derivação de um componente detrítico, em que esses dois óxidos são facilmente 
encontrados. A correlação negativa de $\mathrm{Fe}_{2} \mathrm{O}_{3}$ com $\mathrm{SiO}_{2}$ pode estar associada aos efeitos de concentração por volume de material, em que estes dois elementos competem pela maior participação.

\begin{tabular}{|c|c|c|c|c|c|c|c|c|c|c|c|}
\hline \multicolumn{12}{|c|}{ Pearson Correlation Coefficients for CIF ( $n=9)$} \\
\hline & $\mathrm{SiO}_{2}$ & $\mathrm{TiO}_{2}$ & $\mathrm{Al}_{2} \mathrm{O}_{3}$ & $\mathrm{Fe}_{2} \mathrm{O}_{3}$ & $\mathrm{MnO}$ & $\mathrm{MgO}$ & $\mathrm{CaO}$ & $\mathrm{Na}_{2} \mathrm{O}$ & $\mathrm{K}_{2} \mathrm{O}$ & $\mathrm{P}_{2} \mathrm{O}_{5}$ & LOI \\
\hline $\mathrm{SiO}_{2}$ & 1.00 & 0.58 & 0.83 & -0.18 & 0.23 & -0.44 & -0.46 & 0.07 & 0.82 & -0.20 & -0.45 \\
\hline $\mathrm{TiO}_{2}$ & & 1.00 & 0.65 & 0.10 & 0.59 & -0.46 & -0.57 & 0.59 & 0.71 & 0.02 & -0.53 \\
\hline $\mathrm{Al}_{2} \mathrm{O}_{3}$ & & & 1.00 & -0.30 & 0.30 & -0.20 & -0.33 & 0.02 & 0.96 & -0.15 & -0.28 \\
\hline $\mathrm{Fe}_{2} \mathrm{O}_{3}$ & & & & 1.00 & -0.14 & -0.78 & -0.76 & -0.22 & -0.34 & 0.46 & -0.79 \\
\hline $\mathrm{MnO}$ & & & & & 1.00 & -0.06 & -0.17 & 0.53 & 0.46 & -0.38 & -0.12 \\
\hline $\mathrm{MgO}$ & & & & & & 1.00 & 0.94 & 0.13 & -0.15 & -0.30 & 0.97 \\
\hline $\mathrm{CaO}$ & & & & & & & 1.00 & 0.05 & -0.31 & -0.21 & 0.99 \\
\hline $\mathrm{Na}_{2} \mathrm{O}$ & & & & & & & & 1.00 & 0.21 & -0.21 & 0.09 \\
\hline $\mathrm{K}_{2} \mathrm{O}$ & & & & & & & & & 1.00 & -0.36 & -0.24 \\
\hline $\mathrm{P}_{2} \mathrm{O}_{5}$ & & & & & & & & & & 1.00 & -0.31 \\
\hline
\end{tabular}

Tabela 5 - Coeficientes de correlação de Pearson para formações ferríferas clásticas. Valores positivos que se aproximam de 1 (verde) representam correlações positivas, enquanto valores negativos próximos de -1 (vermelho) representam correlações inversamente proporcionais.

A fácies geoquímica definida como formação ferrífera clástica (Clastic Iron Formation - $C I F)$ mostrou maior aporte de sedimentos extrabacinais. A correlação das amostras dessa fácies mostrou níveis de significância muito bons $(\mathrm{P}<0.01)$ para as correlações entre $\mathrm{CaO} x$ $\mathrm{MgO}$ (positiva forte), $\mathrm{K}_{2} \mathrm{O} \times \mathrm{Al}_{2} \mathrm{O}_{3}$ (positiva forte) e valores de correlação bons ( $\left.\mathrm{P}<0.05\right)$ para $\mathrm{Al}_{2} \mathrm{O}_{3} \times \mathrm{SiO}_{2}$ (positiva forte), $\mathrm{K}_{2} \mathrm{O}$ com $\mathrm{SiO}_{2}$ e $\mathrm{TiO}_{2}$ (positiva forte) e correlações negativas de $\mathrm{Fe}_{2} \mathrm{O}_{3}$ com $\mathrm{MgO}$ e $\mathrm{CaO}$. Análises de correlação de grau de significância menores, mas ainda bons $(\mathrm{P}<0.1)$, mostram correlações positivas de $\mathrm{TiO}_{2}$ com $\mathrm{Al}_{2} \mathrm{O}_{3}, \mathrm{MnO}$ e $\mathrm{Na}_{2} \mathrm{O}$.

As correlações de positivas de $\mathrm{CaO}$ x $\mathrm{MgO}$, como anteriormente referido, se devem, provavelmente, à formação de carbonatos na sequência. A correlação positiva forte de $\mathrm{K}_{2} \mathrm{O} x$ $\mathrm{Al}_{2} \mathrm{O}_{3}$, assim como as correlações positivas de $\mathrm{Al}_{2} \mathrm{O}_{3}$ x $\mathrm{SiO}_{2}$ e de $\mathrm{K}_{2} \mathrm{O}$ com $\mathrm{SiO}_{2}$ e $\mathrm{TiO}_{2}$, devemse principalmente à contribuição de sedimentos extrabacinais, que em sua grande maioria são compostos por fragmentos de granitos. Correlações positivas de $\mathrm{TiO}_{2}$ com $\mathrm{Al}_{2} \mathrm{O}_{3}$ e $\mathrm{Na}_{2} \mathrm{O}$ mostram que os mecanismos de fornecimento destes elementos para rocha estão diretamente acoplados e sugerem ser resultado do aporte de sedimentos detríticos para a bacia (Cox et al., 2013). A correlação negativa de $\mathrm{Fe}_{2} \mathrm{O}_{3}$ com $\mathrm{CaO}$ e $\mathrm{MgO}$ aponta para mecanismos diferenciados de fornecimento destes elementos para a sequência. 
Pearson Correlation Coefficients for AS $(n=5)$

$\begin{array}{cccccccccccc} & \mathrm{SiO}_{2} & \mathrm{TiO}_{2} & \mathrm{Al}_{2} \mathrm{O}_{3} & \mathrm{Fe}_{2} \mathrm{O}_{3} & \mathrm{MnO} & \mathrm{MgO} & \mathrm{CaO} & \mathrm{Na}_{2} \mathrm{O} & \mathrm{K}_{2} \mathrm{O} & \mathrm{P}_{2} \mathrm{O}_{5} & \text { LOI } \\ \mathrm{SiO}_{2} & 1.00 & -0.18 & -0.43 & -0.49 & -0.19 & -0.31 & -0.09 & -0.36 & 0.47 & -0.79 & -0.27 \\ \mathrm{TiO}_{2} & & 1.00 & 0.64 & 0.25 & -0.61 & 0.14 & -0.63 & -0.63 & 0.38 & -0.21 & 0.45 \\ \mathrm{Al}_{2} \mathrm{O}_{3} & & & 1.00 & -0.30 & -0.79 & 0.76 & 0.19 & 0.13 & 0.08 & 0.01 & 0.91 \\ \mathrm{Fe}_{2} \mathrm{O}_{3} & & & & 1.00 & 0.60 & -0.55 & -0.70 & -0.40 & -0.16 & 0.47 & -0.48 \\ \mathrm{MnO} & & & & 1.00 & -0.53 & -0.08 & 0.19 & -0.52 & 0.57 & -0.84 \\ \mathrm{MgO} & & & & & 1.00 & 0.62 & 0.62 & -0.43 & 0.28 & 0.63 \\ \mathrm{CaO} & & & & & & & 1.00 & 0.92 & -0.40 & 0.21 & 0.33 \\ \mathrm{Na}_{2} \mathrm{O} & & & & & & & 1.00 & -0.71 & 0.58 & 0.14 \\ \mathrm{~K}_{2} \mathrm{O} & & & & & & & & 1.00 & -0.89 & 0.34 \\ \mathrm{P}_{2} \mathrm{O}_{5} & & & & & & & & & 1.00 & -0.23\end{array}$

Tabela 6 - Coeficientes de correlação de Pearson para arenitos arcoseanos. Valores positivos que se aproximam de 1 (verde) representam correlações positivas, enquanto valores negativos próximos de -1 (vermelho) representam correlações inversamente proporcionais.

A fácies de arenito arcoseano (Arkosean Sandstone - AS) não apresentou muitos valores de significância $(\mathrm{P})$ importantes, devido ao número restrito de amostras $(\mathrm{n}=5)$. Em relação aos valores que mostraram significância com valores bons $(\mathrm{P}<0.05)$ vale citar a correlação de $\mathrm{Na}_{2} \mathrm{O} \times \mathrm{CaO}$ (positiva forte) e a correlação de $\mathrm{P}_{2} \mathrm{O}_{5} \times \mathrm{K}_{2} \mathrm{O}$ (negativa forte). A correlação negativa de $\mathrm{P}_{2} \mathrm{O}_{5} \times \mathrm{K}_{2} \mathrm{O}$ sugere possíveis fontes diferentes, devido à falta de correlação entre $\mathrm{P}_{2} \mathrm{O}_{5}$ e $\mathrm{Al}_{2} \mathrm{O}_{3}$ e a correlação negativa com $\mathrm{SiO}_{2}$ e com $\mathrm{TiO}_{2}$. A forte participação de componente detrítico para a origem do fósforo pode ser descartada (Cox et al., 2013).

\subsubsection{Elementos Terras Raras e Y}

Os resultados da análise de elementos terras raras e ítrio de 24 amostras selecionadas estão representados graficamente (Fig. 30) para os 3 grupos: formações ferríferas puras (IF), formações ferríferas clásticas (CIF) e arenitos arcoseanos (AS). A representação e comparação de ETR+Y das três fácies litogeoquímicas foram normalizados ao PAAS (Post Archean Australian Shale) (McLennan, 1989) para atenuação do efeito Oddo-Harkins (McLennan \& Taylor, 2012) e efeito de comparação quanto ao enriquecimento nos valores dos elementos terras raras.

A representação dos padrões de ETRs e Y das amostras mostra depleção em elementos terras raras leves em relação aos elementos terras raras pesadas, segundo o PAAS. Esta característica se mostra mais forte nas formações ferríferas puras (cor cinza) (Fig. 30A) e menos marcante para as formações ferríferas clásticas e para os sedimentos não ferruginosos (Fig. 30 
B, 30 C). O enriquecimento de elementos terras raras nas amostras mais clásticas é resultante da contribuição de fontes continentais para estas amostras, enquanto as formações ferríferas puras se assemelham mais aos padrões da água do mar.
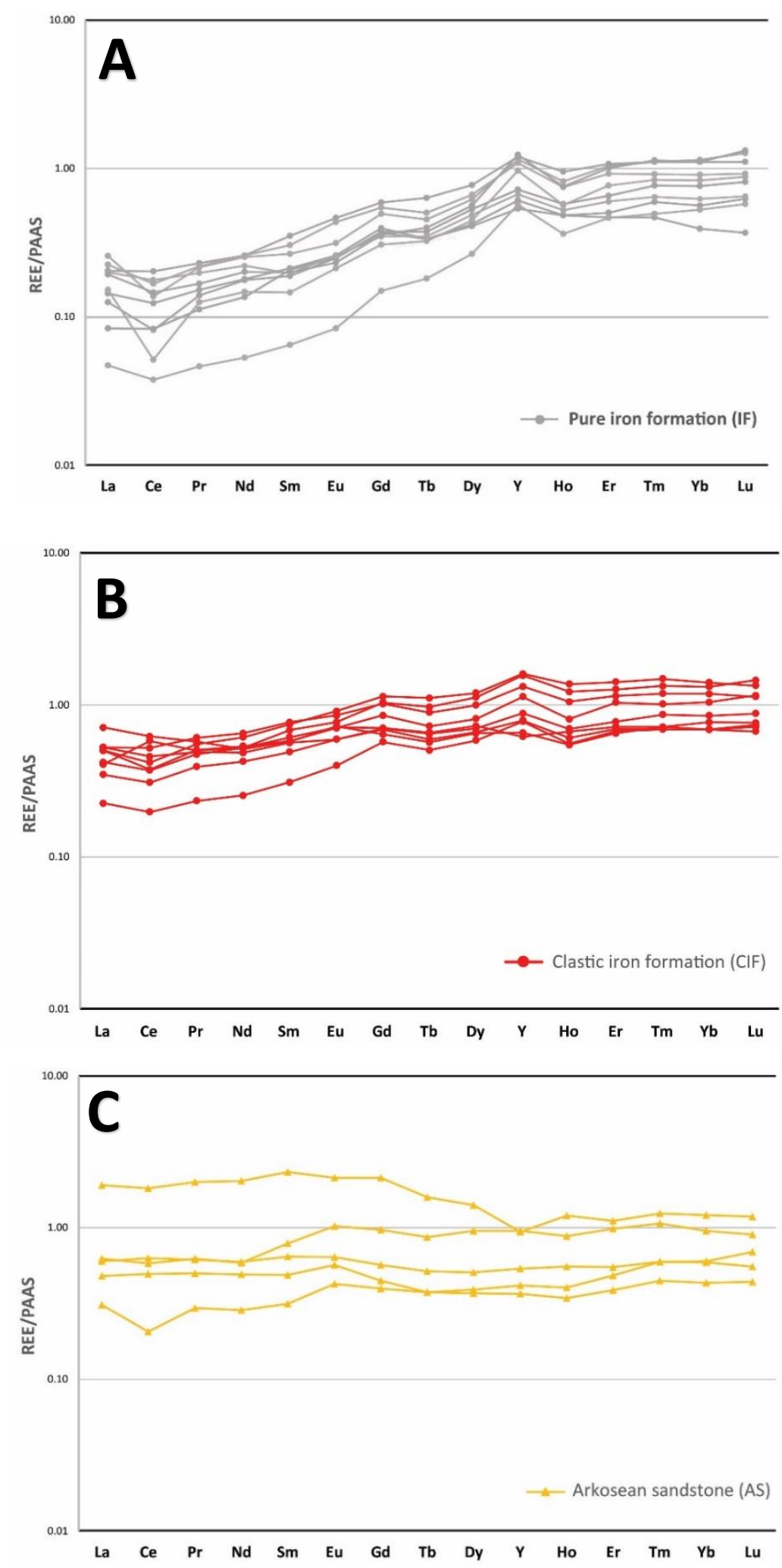
Figura 30 - Padrões de ETR $+Y$ das amostras da região da Morraria Grande. Elementos estão ordenados em ordem decrescente de raio iônico em estado de oxidação +3 e coordenação octaédrica (Bau \& Dulski, 1996). Padrões de ETR+Y para (A) formações ferríferas puras; (B) formações ferríferas clásticas; $(C)$ arenitos arcoseanos.

As amostras normalizadas segundo o PAAS, não mostram anomalias positivas de Eu observadas nas formações ferríferas paleoproterozoicas e arqueanas. A ausência desta anomalia é tentativamente explicada por contaminação das formações ferríferas por sedimentos clásticos (Baldwin et al., 2012). No entanto esta anomalia não está presente nas formações ferríferas puras analisada. Outra teoria atribuí a origem a fontes hidrotermais de baixas temperaturas que não apresentam anomalia de Eu, ao contrário das fontes hidrotermais de alta temperatura.

Segundo Bau \& Dulski (1996), a anomalia de Ce resulta da oxidação do $\mathrm{Ce}^{3+}$ para $\mathrm{Ce}^{4+}$, sua forma menos solúvel ou/e de mais fácil absorção por superfícies de partículas. Nos gráficos gerados para os elementos terras raras, a anomalia negativa em Ce está marcada em algumas formações ferríferas puras e clásticas, enquanto tal anomalia se demonstra suavizada nos sedimentos, exceto por apenas duas amostras que apresentam padrão com leve anomalia negativa de Ce, possivelmente devida a alguma camada ou lâmina de óxido presente.

Em algumas ocasiões concentrações anômalas de La podem dificultar a identificação da anomalia de Ce em gráficos de distribuição dos elementos terras raras. Por isso, usa-se como ferramenta a razão $\left(\operatorname{Pr} / \mathrm{Pr}^{*}\right)_{\mathrm{SN}}$ (SN identifica amostras normalizadas ao PAAS ou Shale Normalized), onde valores $(\operatorname{Pr} / \operatorname{Pr} *)_{\mathrm{SN}}>1$ representam anomalias negativas de Ce e valores $\left(\operatorname{Pr} / \mathrm{Pr}^{*}\right)_{\mathrm{SN}}<1$ são devidos a anomalias positivas de Ce. Valores de $\left(\mathrm{Ce} / \mathrm{Ce}{ }^{*}\right)_{\mathrm{SN}}<1$ e $\left(\operatorname{Pr} / \mathrm{Pr}{ }^{*}\right)_{\mathrm{SN}}$ $\approx 1$ são representativos de anomalias de La (Fig. 31) (Planavsky et al., 2010).

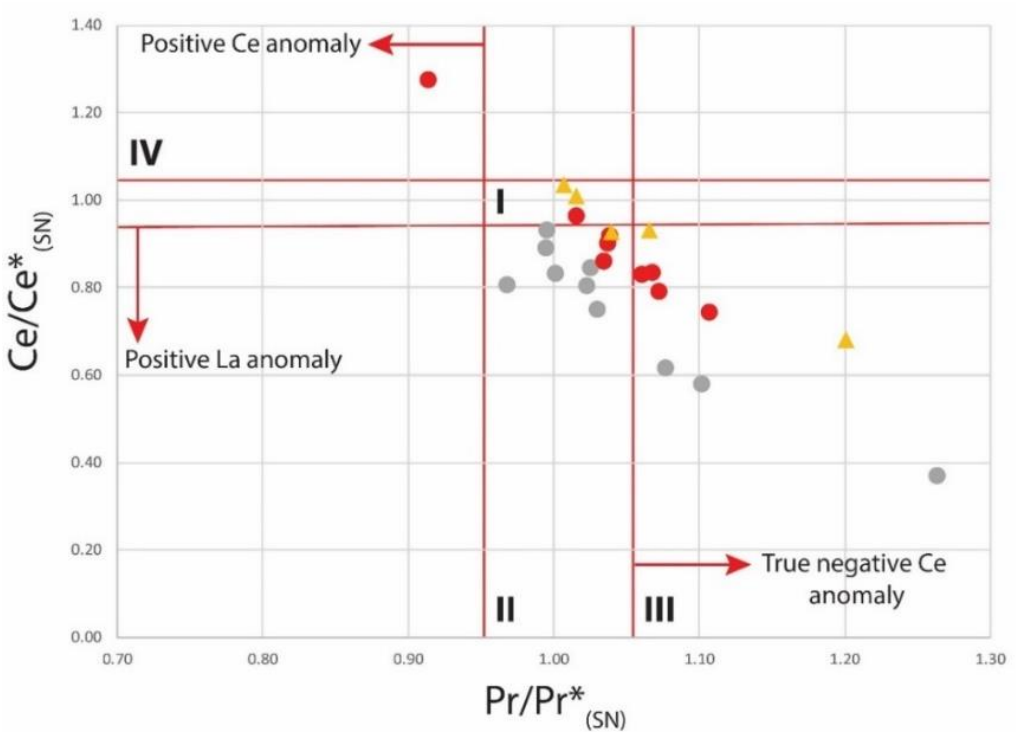

Figura 31 - Gráfico de Ce/Ce*(SN) vs $\operatorname{Pr} / \operatorname{Pr} *(S N)$ para amostras de sedimentos do Grupo Jacadigo da Morraria Grande. Números representam os campos referentes a cada anomalia. (I) sem anomalia; (II) anomalia positiva de La; (III) anomalia negativa de Ce; (IV) anomalia positiva de Ce (Bau \& Dulski, 1996; Bekker et al., 2010). 
Tabela 7 - Elementos maiores e traços para amostras de formações ferríferas e sedimentos arcoseanos do Grupo Jacadigo.

\begin{tabular}{|c|c|c|c|c|c|c|c|c|c|c|c|c|c|c|c|c|}
\hline $\begin{array}{c}\text { Amostra } \\
\text { Tipo }\end{array}$ & $\begin{array}{c}\text { MG-01 } \\
\text { IF }\end{array}$ & $\begin{array}{c}\text { MG-02 } \\
\text { IF }\end{array}$ & $\begin{array}{c}\text { MG-03 } \\
\text { IF }\end{array}$ & $\begin{array}{c}\text { SC-01 } \\
\text { IF }\end{array}$ & $\begin{array}{c}\text { SC-03 } \\
\text { IF }\end{array}$ & $\begin{array}{c}\text { SC-04 } \\
\text { IF }\end{array}$ & $\begin{array}{c}\text { SC-05 } \\
\text { IF }\end{array}$ & $\begin{array}{c}\text { SC-06 } \\
\text { IF }\end{array}$ & $\begin{array}{c}\text { UB-02 } \\
\text { IF }\end{array}$ & $\begin{array}{c}\text { UB-07 } \\
\text { IF }\end{array}$ & $\begin{array}{c}\text { MG-04 } \\
\text { CIF }\end{array}$ & $\begin{array}{c}\text { MG-05 } \\
\text { CIF }\end{array}$ & $\begin{array}{c}\text { MG-06 } \\
\text { CIF }\end{array}$ & $\begin{array}{c}\text { MG-07 } \\
\text { CIF }\end{array}$ & $\begin{array}{c}\text { SC-02 } \\
\text { CIF }\end{array}$ & $\begin{array}{c}\text { SC-07 } \\
\text { CIF }\end{array}$ \\
\hline \multicolumn{17}{|l|}{$(\% p / p)$} \\
\hline $\mathrm{SiO}_{2}$ & 32.13 & 16.22 & 17.41 & 58.11 & 52.81 & 47.56 & 15.37 & 24.24 & 36.01 & 24.54 & 10.61 & 23.09 & 20.23 & 38.11 & 24.22 & 32.36 \\
\hline $\mathrm{TiO}_{2}$ & 0.02 & 0.02 & 0.02 & 0.02 & 0.03 & 0.03 & 0.03 & 0.03 & 0.03 & 0.02 & 0.10 & 0.13 & 0.11 & 0.21 & 0.14 & 0.32 \\
\hline $\mathrm{Al}_{2} \mathrm{O}_{3}$ & 0.11 & 0.05 & 0.18 & 0.11 & 0.28 & 0.31 & 0.09 & 0.07 & 0.36 & 0.06 & 1.22 & 1.75 & 2.19 & 6.29 & 2.31 & 4.05 \\
\hline $\mathrm{Fe}_{2} \mathrm{O}_{3}$ & 67.00 & 63.25 & 35.97 & 41.29 & 45.59 & 47.03 & 81.23 & 68.71 & 60.24 & 63.03 & 20.12 & 49.90 & 45.38 & 24.08 & 71.25 & 48.27 \\
\hline $\mathrm{CaO}$ & 0.07 & 7.21 & 16.63 & $<0.01$ & 0.20 & 1.87 & 1.70 & 3.48 & 0.25 & 6.31 & 22.34 & 8.95 & 10.04 & 8.42 & 0.03 & 1.94 \\
\hline $\mathrm{Cr}_{2} \mathrm{O}_{3}$ & 0.070 & 0.034 & 0.012 & 0.063 & 0.048 & 0.071 & 0.163 & 0.085 & 0.035 & 0.045 & 0.006 & 0.015 & 0.014 & 0.025 & 0.030 & 0.029 \\
\hline $\mathrm{MgO}$ & $<0.01$ & 2.91 & 6.27 & $<0.01$ & $<0.01$ & 0.25 & 0.01 & 0.18 & 0.07 & 0.16 & 9.87 & 1.89 & 4.39 & 4.82 & 0.04 & 1.08 \\
\hline $\mathrm{Na}_{2} \mathrm{O}$ & 0.01 & 0.02 & 0.04 & $<0.01$ & 0.01 & 0.04 & 0.02 & 0.02 & 0.01 & 0.01 & 0.65 & 0.07 & 0.03 & 0.04 & 0.02 & 1.21 \\
\hline $\mathrm{K}_{2} \mathrm{O}$ & $<0.01$ & $<0.01$ & $<0.01$ & $<0.01$ & 0.02 & 0.08 & $<0.01$ & $<0.01$ & 0.01 & $<0.01$ & 0.33 & 0.39 & 0.48 & 1.48 & 0.59 & 1.15 \\
\hline $\mathrm{MnO}$ & 0.03 & 0.32 & 0.29 & $<0.01$ & 0.14 & 0.25 & 0.05 & 0.18 & 0.09 & 0.05 & 0.38 & 2.57 & 2.53 & 2.55 & 0.15 & 5.73 \\
\hline $\mathrm{P}_{2} \mathrm{O}_{5}$ & 0.05 & 0.36 & 0.42 & 0.06 & 0.11 & 0.72 & 0.48 & 0.61 & 0.56 & 0.30 & 0.19 & 0.36 & 0.47 & 0.15 & 0.09 & 0.16 \\
\hline LOI & 0.5 & 9.5 & 22.6 & 0.3 & 0.7 & 1.7 & 0.8 & 2.3 & 2.3 & 5.4 & 33.5 & 10.7 & 14.0 & 13.6 & 1.0 & 3.6 \\
\hline \multicolumn{17}{|l|}{ Ppm } \\
\hline $\mathrm{Sc}$ & 4 & 3 & 3 & 2 & 4 & 2 & 3 & 4 & 2 & 5 & 4 & 9 & 6 & 8 & 7 & 9 \\
\hline $\mathrm{Co}$ & 2.5 & 2.1 & 2.0 & 1.7 & 3.2 & 11.3 & 4.0 & 5.9 & 2.5 & 1.2 & 6.9 & 24.8 & 53.5 & 127.2 & 3.4 & 124.9 \\
\hline $\mathrm{Ni}$ & 9.2 & 5.5 & 2.9 & 8.1 & 7.6 & 13.6 & 19.9 & 13.3 & 6.0 & 6.2 & 3.2 & 9.2 & 16.6 & 62.0 & 9.1 & 57.6 \\
\hline $\mathrm{Cu}$ & 4.5 & 2.3 & 0.9 & 3.4 & 6.0 & 4.8 & 8.3 & 14.2 & 7.4 & 2.5 & 2.7 & 1.3 & 1.8 & 1.7 & 8.1 & 8.7 \\
\hline $\mathrm{Zn}$ & $<1$ & 3 & 12 & 1 & 2 & 3 & 1 & 2 & 9 & 2 & 26 & 9 & 9 & 7 & 12 & 14 \\
\hline As & 2.0 & 1.4 & 0.9 & 2.8 & 2.1 & 3.6 & 5.0 & 2.6 & 0.7 & 1.4 & 0.6 & 2.9 & 1.5 & 0.7 & 3.5 & 4.6 \\
\hline $\mathrm{Rb}$ & $<0.1$ & $<0.1$ & 0.5 & 0.1 & 0.5 & 2.3 & 0.3 & $<0.1$ & 0.3 & $<0.1$ & 10.6 & 14.0 & 20.1 & 44.5 & 19.5 & 37.3 \\
\hline $\mathrm{Sr}$ & 37.8 & 233.5 & 348.4 & 32.6 & 115.1 & 234.3 & 59.0 & 57.1 & 37.8 & 104.9 & 3492.4 & 406.1 & 76.4 & 44.1 & 70.6 & 212.9 \\
\hline $\mathrm{Y}$ & 18.1 & 26.0 & 29.4 & 14.5 & 31.2 & 19.4 & 16.4 & 32.3 & 15.4 & 33.5 & 21.0 & 35.7 & 42.2 & 17.7 & 30.5 & 16.7 \\
\hline $\mathrm{Zr}$ & 17.3 & 5.6 & 4.9 & 14.6 & 8.9 & 11.9 & 12.1 & 4.8 & 11.7 & 4.8 & 30.5 & 33.5 & 41.3 & 73.4 & 47.6 & 105.9 \\
\hline $\mathrm{Nb}$ & 0.4 & $<0.1$ & 0.2 & 1.3 & 0.9 & 1.4 & 0.6 & 0.4 & 0.8 & $<0.1$ & 2.0 & 2.0 & 1.7 & 4.9 & 3.7 & 9.1 \\
\hline $\mathrm{Ba}$ & 29 & 44 & 47 & 99 & 157 & 34 & 21 & 61 & 184 & 18 & 400 & 181 & 199 & 349 & 324 & 383 \\
\hline $\mathrm{Hf}$ & 0.2 & $<0.1$ & $<0.1$ & 0.4 & 0.2 & 0.3 & 0.1 & $<0.1$ & 0.3 & $<0.1$ & 0.7 & 0.8 & 1.1 & 1.6 & 1.2 & 2.3 \\
\hline
\end{tabular}




\begin{tabular}{|c|c|c|c|c|c|c|c|c|c|c|c|c|c|c|c|c|}
\hline $\mathrm{Ta}$ & $<0.1$ & $<0.1$ & $<0.1$ & $<0.1$ & $<0.1$ & $<0.1$ & $<0.1$ & $<0.1$ & $<0.1$ & $<0.1$ & 0.1 & $<0.1$ & 0.1 & 0.2 & 0.2 & 0.3 \\
\hline $\mathrm{Th}$ & 0.5 & $<0.2$ & 0.3 & $<0.2$ & 0.4 & 0.5 & 0.3 & 0.8 & 0.3 & 0.3 & 1.6 & 3.7 & 2.5 & 3.7 & 1.6 & 5.7 \\
\hline $\mathrm{U}$ & $<0.1$ & $<0.1$ & $<0.1$ & 0.2 & $<0.1$ & $<0.1$ & 0.1 & $<0.1$ & $<0.1$ & $<0.1$ & $<0.1$ & 0.1 & 0.1 & 0.6 & 0.3 & 0.4 \\
\hline $\mathrm{V}$ & 29 & 26 & 19 & 19 & 17 & 35 & 44 & 38 & 18 & 26 & 28 & 52 & 51 & 19 & 48 & 60 \\
\hline Mo & 2.3 & 1.3 & 0.5 & 2.1 & 1.9 & 2.4 & 5.0 & 3.3 & 2.0 & 1.4 & 0.2 & 0.7 & 0.7 & 1.5 & 1.3 & 2.4 \\
\hline $\mathrm{Pb}$ & 0.7 & 0.2 & 0.3 & 0.4 & 0.4 & 0.4 & 0.6 & 18.2 & 0.2 & 0.2 & 2.3 & 3.5 & 2.3 & 3.0 & 4.5 & 10.6 \\
\hline $\mathrm{Cs}$ & $<0.1$ & $<0.1$ & $<0.1$ & $<0.1$ & $<0.1$ & 0.4 & $<0.1$ & $<0.1$ & $<0.1$ & $<0.1$ & $<0.1$ & 0.5 & 0.2 & 0.4 & 0.3 & 1.3 \\
\hline $\mathrm{Ga}$ & 0.6 & $<0.5$ & $<0.5$ & 1.4 & $<0.5$ & $<0.5$ & $<0.5$ & $<0.5$ & $<0.5$ & $<0.5$ & 1.5 & 5.6 & 5.9 & 9.6 & 3.7 & 9.5 \\
\hline \multicolumn{17}{|l|}{ ETR } \\
\hline $\mathrm{Y}$ & 18.1 & 26.0 & 29.4 & 14.5 & 31.2 & 19.4 & 16.4 & 32.3 & 15.4 & 33.5 & 21.0 & 35.7 & 42.2 & 17.7 & 30.5 & 16.7 \\
\hline $\mathrm{La}$ & 7.6 & 5.8 & 8.6 & 5.5 & 9.8 & 3.2 & 4.8 & 7.8 & 1.8 & 7.4 & 8.6 & 20.0 & 16.0 & 27.1 & 19.2 & 15.5 \\
\hline $\mathrm{Ce}$ & 14.1 & 4.1 & 13.3 & 9.8 & 10.9 & 6.6 & 6.5 & 16.1 & 3.0 & 11.6 & 15.7 & 41.4 & 29.5 & 49.3 & 29.8 & 46.1 \\
\hline $\operatorname{Pr}$ & 1.75 & 1.11 & 1.94 & 1.34 & 1.90 & 0.99 & 1.23 & 2.03 & 0.41 & 1.48 & 2.06 & 5.36 & 4.18 & 5.08 & 4.44 & 4.43 \\
\hline $\mathrm{Nd}$ & 7.5 & 5.0 & 8.8 & 6.1 & 8.6 & 4.6 & 6.0 & 8.8 & 1.8 & 6.8 & 8.6 & 22.0 & 17.7 & 17.4 & 18.1 & 17.6 \\
\hline $\mathrm{Sm}$ & 1.09 & 0.81 & 1.69 & 1.18 & 1.48 & 1.15 & 1.05 & 1.95 & 0.36 & 1.11 & 1.72 & 4.27 & 3.78 & 3.18 & 3.20 & 3.40 \\
\hline $\mathrm{Eu}$ & 0.28 & 0.23 & 0.47 & 0.28 & 0.34 & 0.27 & 0.27 & 0.50 & 0.09 & 0.25 & 0.43 & 0.92 & 0.83 & 0.78 & 0.76 & 0.77 \\
\hline $\mathrm{Gd}$ & 1.62 & 1.43 & 2.54 & 1.84 & 2.30 & 1.74 & 1.72 & 2.75 & 0.70 & 1.66 & 2.66 & 4.74 & 4.83 & 2.98 & 3.97 & 3.28 \\
\hline $\mathrm{Tb}$ & 0.27 & 0.25 & 0.39 & 0.26 & 0.35 & 0.29 & 0.26 & 0.49 & 0.14 & 0.31 & 0.39 & 0.69 & 0.75 & 0.44 & 0.56 & 0.51 \\
\hline Dy & 2.28 & 2.08 & 3.10 & 1.91 & 2.90 & 2.49 & 1.97 & 3.63 & 1.24 & 2.64 & 2.73 & 4.66 & 5.26 & 3.04 & 3.79 & 3.40 \\
\hline Ho & 0.52 & 0.56 & 0.74 & 0.48 & 0.81 & 0.57 & 0.48 & 0.94 & 0.36 & 0.75 & 0.55 & 1.04 & 1.21 & 0.54 & 0.80 & 0.66 \\
\hline $\mathrm{Er}$ & 1.71 & 2.19 & 2.62 & 1.33 & 2.97 & 1.86 & 1.43 & 3.05 & 1.32 & 2.87 & 1.92 & 3.26 & 3.60 & 1.85 & 2.95 & 2.05 \\
\hline $\mathrm{Tm}$ & 0.26 & 0.34 & 0.37 & 0.19 & 0.45 & 0.31 & 0.24 & 0.45 & 0.20 & 0.46 & 0.28 & 0.48 & 0.54 & 0.29 & 0.41 & 0.29 \\
\hline $\mathrm{Yb}$ & 1.76 & 2.35 & 2.56 & 1.11 & 3.23 & 2.14 & 1.58 & 3.13 & 1.49 & 3.13 & 1.95 & 3.34 & 3.72 & 2.17 & 2.94 & 1.95 \\
\hline $\mathrm{Lu}$ & 0.28 & 0.38 & 0.40 & 0.16 & 0.55 & 0.35 & 0.27 & 0.48 & 0.25 & 0.57 & 0.32 & 0.49 & 0.63 & 0.33 & 0.50 & 0.31 \\
\hline$\Sigma \mathrm{REE}$ & 41.02 & 26.63 & 47.52 & 31.48 & 46.58 & 26.56 & 27.80 & 52.10 & 13.16 & 41.03 & 47.91 & 112.65 & 92.53 & 114.48 & 91.42 & 100.25 \\
\hline Y/Ho & 34.81 & 46.43 & 39.73 & 30.21 & 38.52 & 34.04 & 34.17 & 34.36 & 42.78 & 44.67 & 38.18 & 34.33 & 34.88 & 32.78 & 38.13 & 25.30 \\
\hline$(\mathrm{Pr} / \mathrm{Yb})_{\mathrm{SN}}$ & 0.32 & 0.15 & 0.24 & 0.39 & 0.19 & 0.15 & 0.25 & 0.21 & 0.09 & 0.15 & 0.34 & 0.51 & 0.36 & 0.75 & 0.48 & 0.73 \\
\hline $\mathrm{Sm} / \mathrm{Yb}$ & 0.62 & 0.34 & 0.66 & 1.06 & 0.46 & 0.54 & 0.66 & 0.62 & 0.24 & 0.35 & 0.88 & 1.28 & 1.02 & 1.47 & 1.09 & 1.74 \\
\hline$(\mathrm{La} / \mathrm{Sm})_{\mathrm{SN}}$ & 1.01 & 1.04 & 0.74 & 0.68 & 0.96 & 0.40 & 0.66 & 0.58 & 0.73 & 0.97 & 0.73 & 0.68 & 0.61 & 1.24 & 0.87 & 0.66 \\
\hline $\mathrm{Eu} / \mathrm{Sm}$ & 0.26 & 0.28 & 0.28 & 0.24 & 0.23 & 0.23 & 0.26 & 0.26 & 0.25 & 0.23 & 0.25 & 0.22 & 0.22 & 0.25 & 0.24 & 0.23 \\
\hline
\end{tabular}




\begin{tabular}{|c|c|c|c|c|c|c|c|c|c|c|c|c|c|c|c|c|c|}
\hline$\left(\mathrm{Eu} / \mathrm{Eu}^{*}\right)_{\mathrm{SN}}$ & 1.05 & 1.04 & 1.18 & 1.02 & 0.96 & 0.95 & 1.05 & 1.04 & 0.81 & 0.87 & 1.06 & 1.05 & 0.99 & 1.26 & 1.13 & 1.14 & \\
\hline$\left(\mathrm{La} / \mathrm{La}^{*}\right)_{\mathrm{SN}}$ & 1.31 & 1.85 & 1.61 & 1.51 & 1.86 & 1.29 & 1.97 & 1.20 & 1.42 & 1.91 & 1.17 & 1.00 & 1.11 & 1.01 & 1.14 & 0.87 & \\
\hline$\left(\mathrm{Ce} / \mathrm{Ce}^{*}\right)_{\mathrm{SN}}$ & 1.01 & 0.50 & 0.93 & 1.00 & 0.78 & 0.94 & 0.80 & 1.01 & 0.95 & 1.08 & 0.93 & 0.92 & 0.87 & 0.97 & 0.79 & 1.20 & \\
\hline$(\operatorname{Pr} / \operatorname{Pr} *)_{S N}$ & 0.99 & 1.26 & 1.03 & 1.00 & 1.10 & 1.03 & 1.08 & 1.00 & 1.02 & 0.97 & 1.03 & 1.04 & 1.06 & 1.02 & 1.11 & 0.91 & \\
\hline$\left(\mathrm{Gd} / \mathrm{Gd}^{*}\right)_{\mathrm{SI}}$ & 1.16 & 1.16 & 1.24 & 1.34 & 1.26 & 1.17 & 1.28 & 1.09 & 1.05 & 1.07 & 1.30 & 1.20 & 1.19 & 1.12 & 1.26 & 1.09 & \\
\hline Amostra & SC-08 & UB-04 & UB-06 & SC-09 & SC-10 & UB-01 & UB-03 & UB-05 & & SC-08 & UB-04 & UB-06 & SC-09 & SC-10 & UB-01 & UB-03 & UB-05 \\
\hline Tipo & CIF & CIF & CIF & AS & AS & AS & AS & AS & & CIF & CIF & CIF & AS & AS & AS & AS & AS \\
\hline $\mathrm{SiO}_{2}$ & 26.76 & 19.30 & 43.43 & 59.59 & 69.62 & 61.28 & 60.77 & 56.82 & Y/Ho & 34.49 & 31.76 & 35.50 & 28.00 & 29.12 & 21.26 & 26.36 & 29.54 \\
\hline $\mathrm{TiO}_{2}$ & 0.17 & 0.20 & 0.19 & 0.18 & 0.29 & 0.68 & 0.30 & 0.45 & $(\mathrm{Pr} / \mathrm{Yb})_{\mathrm{SN}}$ & 0.46 & 0.39 & 0.71 & 0.49 & 1.15 & 1.65 & 1.04 & 0.66 \\
\hline $\mathrm{Al}_{2} \mathrm{O}_{3}$ & 2.54 & 2.62 & 4.09 & 6.66 & 8.14 & 9.98 & 10.02 & 11.58 & $\mathrm{Sm} / \mathrm{Yb}$ & 1.14 & 1.05 & 1.61 & 1.03 & 2.22 & 3.77 & 2.14 & 1.62 \\
\hline $\mathrm{Fe}_{2} \mathrm{O}_{3}$ & 43.99 & 71.14 & 35.02 & 13.83 & 2.16 & 12.95 & 4.58 & 6.24 & $(\mathrm{La} / \mathrm{Sm})_{\mathrm{SN}}$ & 0.71 & 0.67 & 0.94 & 0.99 & 0.98 & 0.82 & 0.93 & 0.80 \\
\hline $\mathrm{CaO}$ & 7.23 & 2.49 & 6.51 & 3.72 & 4.62 & 0.46 & 5.85 & 5.83 & $\mathrm{Eu} / \mathrm{Sm}$ & 0.24 & 0.24 & 0.21 & 0.26 & 0.23 & 0.18 & 0.19 & 0.25 \\
\hline $\mathrm{Cr}_{2} \mathrm{O}_{3}$ & 0.020 & 0.023 & 0.027 & 0.038 & 0.069 & 0.020 & 0.055 & 0.056 & $\left(\mathrm{Eu} / \mathrm{Eu}^{*}\right)_{\mathrm{SN}}$ & 1.09 & 1.05 & 1.03 & 1.28 & 1.25 & 1.02 & 1.06 & 1.26 \\
\hline $\mathrm{MgO}$ & 4.16 & 0.66 & 1.27 & 2.14 & 3.10 & 2.45 & 3.13 & 4.86 & $\left(\mathrm{La} / \mathrm{La}^{*}\right)_{\mathrm{SN}}$ & 1.07 & 1.16 & 1.06 & 0.98 & 0.92 & 0.99 & 0.91 & 0.90 \\
\hline $\mathrm{Na}_{2} \mathrm{O}$ & 0.73 & 0.22 & 0.41 & 1.92 & 1.54 & 0.47 & 1.97 & 2.47 & $\left(\mathrm{Ce} / \mathrm{Ce}^{*}\right)_{\mathrm{SN}}$ & 0.86 & 0.85 & 0.93 & 0.68 & 0.97 & 0.92 & 0.99 & 0.88 \\
\hline $\mathrm{K}_{2} \mathrm{O}$ & 0.69 & 0.44 & 0.91 & 2.08 & 2.73 & 3.07 & 3.01 & 1.94 & $\left(\operatorname{Pr} / \mathrm{Pr}^{*}\right)_{\mathrm{SN}}$ & 1.07 & 1.07 & 1.04 & 1.20 & 1.02 & 1.04 & 1.01 & 1.07 \\
\hline $\mathrm{MnO}$ & 2.97 & 0.03 & 0.14 & 3.82 & 0.27 & 0.05 & 0.09 & 0.08 & $\left(\mathrm{Gd} / \mathrm{Gd}^{*}\right)_{\mathrm{SN}}$ & 1.18 & 1.15 & 1.18 & 1.11 & 1.08 & 1.16 & 1.01 & 1.16 \\
\hline $\mathrm{P}_{2} \mathrm{O}_{5}$ & 0.29 & 1.29 & 0.47 & 0.11 & 0.07 & 0.08 & 0.08 & 0.11 & & & & & & & & & \\
\hline LOI & 10.3 & 1.5 & 7.4 & 5.6 & 7.3 & 8.3 & 9.8 & 9.3 & & & & & & & & & \\
\hline \multicolumn{18}{|l|}{ Ppm } \\
\hline $\mathrm{Sc}$ & 6 & 7 & 5 & 6 & 3 & 13 & 6 & 16 & & & & & & & & & \\
\hline Co & 129.2 & 2.2 & 3.4 & 226.0 & 11.5 & 7.8 & 9.2 & 14.1 & & & & & & & & & \\
\hline $\mathrm{Ni}$ & 33.7 & 7.4 & 6.3 & 70.1 & 14.0 & 20.2 & 26.6 & 25.3 & & & & & & & & & \\
\hline $\mathrm{Cu}$ & 2.2 & 3.2 & 10.7 & 10.0 & 3.7 & 24.0 & 14.4 & 19.1 & & & & & & & & & \\
\hline $\mathrm{Zn}$ & 16 & 11 & 10 & 7 & 8 & 28 & 17 & 50 & & & & & & & & & \\
\hline As & 3.8 & 3.1 & 1.2 & 1.6 & $<0.5$ & 2.2 & 1.8 & 0.6 & & & & & & & & & \\
\hline $\mathrm{Rb}$ & 23.4 & 14.7 & 33.1 & 70.7 & 89.9 & 115.2 & 87.6 & 69.1 & & & & & & & & & \\
\hline $\mathrm{Sr}$ & 213.8 & 93.4 & 256.1 & 254.7 & 100.3 & 27.5 & 165.3 & 136.8 & & & & & & & & & \\
\hline $\mathrm{Y}$ & 23.8 & 43.2 & 21.3 & 11.2 & 9.9 & 25.3 & 14.5 & 25.7 & & & & & & & & & \\
\hline $\mathrm{Zr}$ & 74.3 & 51.9 & 68.4 & 63.9 & 144.3 & 186.5 & 88.0 & 121.9 & & & & & & & & & \\
\hline
\end{tabular}




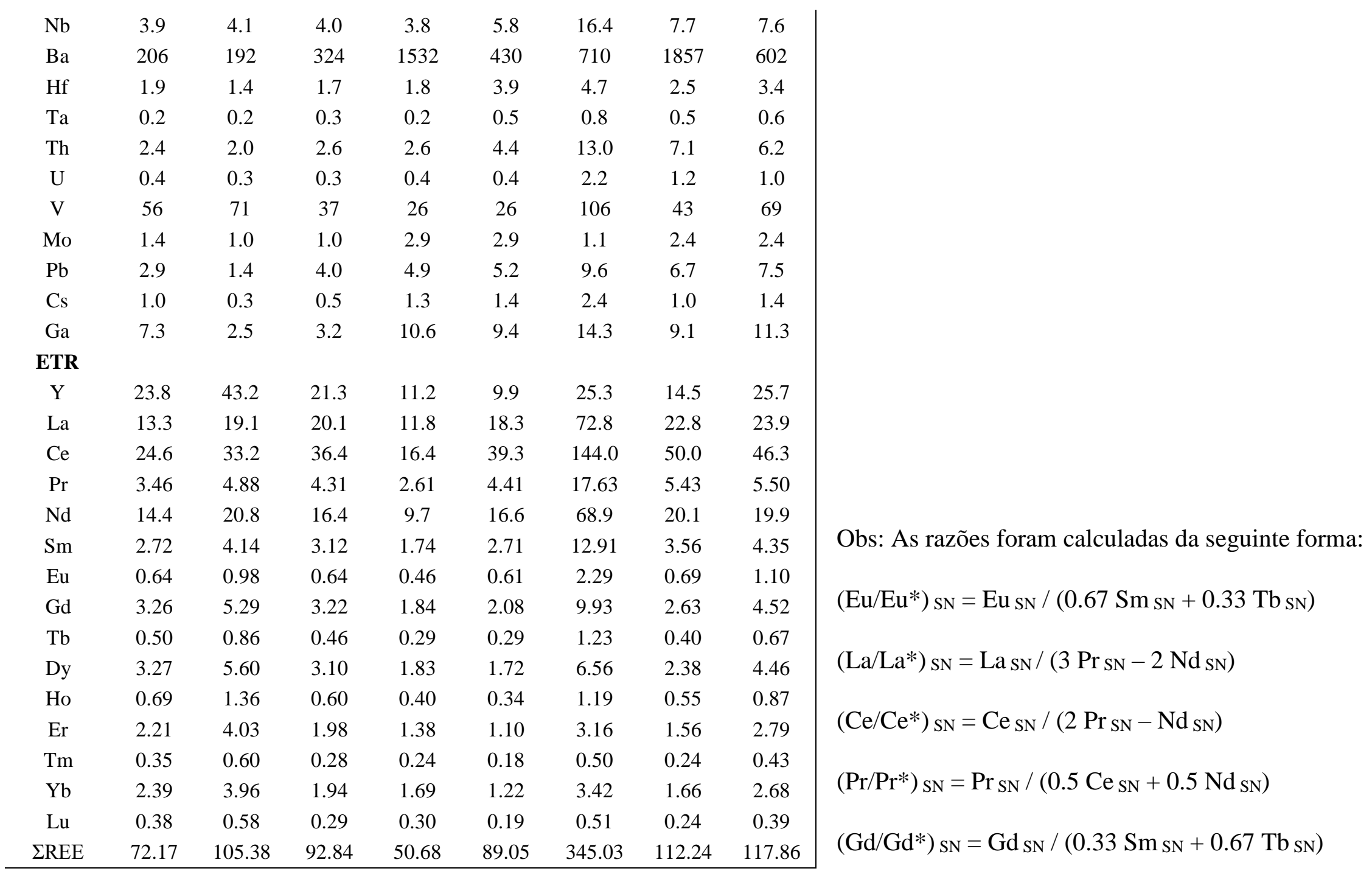


A anomalia positiva de Y, suavizada nas porções clásticas, está fortemente marcada nas formações ferríferas puras e levemente presente nas formações ferríferas clásticas. As razões de Y/Ho para as rochas analisadas mostram valores supercondríticos (Y/Ho > 27.7) comum para formações ferríferas do neoproterozoico e semelhante a água do mar (Cox et al., 2013).
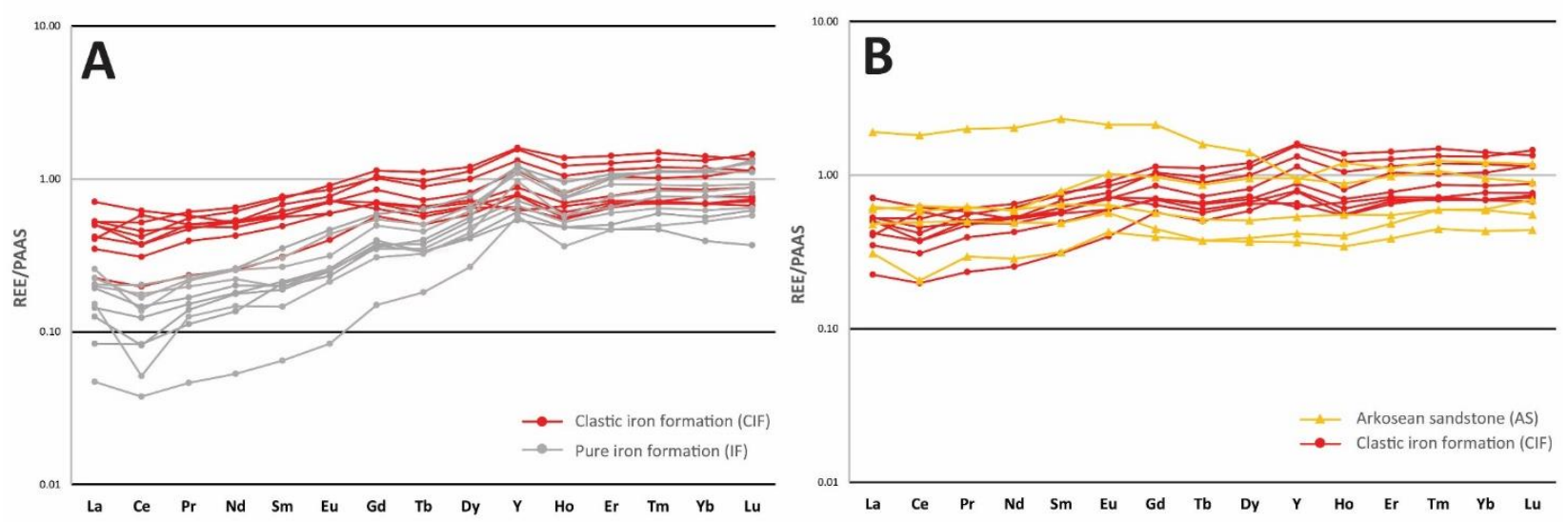

Figura 32 - Comparação dos padrões de ETRs e $Y$, (A) entre amostras de CIF e IF, (B) entre amostras de CIF e AS.

A comparação do padrão de ETR (Fig. 32) entre amostras de formação ferrífera pura e de formação ferrífera clástica mostra que os dois grupos apresentam semelhanças entre os padrões, sendo as formações ferríferas clásticas mais enriquecidas em elementos terras raras leves em relação as formações ferríferas puras. O gráfico de comparação entre as formações ferríferas clásticas e o grupo de amostras de arenitos arcoseanos demonstra que há forte similaridade entre os padrões destes dois grupos, sendo o padrão de ETR dos arenitos mais ondulado e heterogêneo.
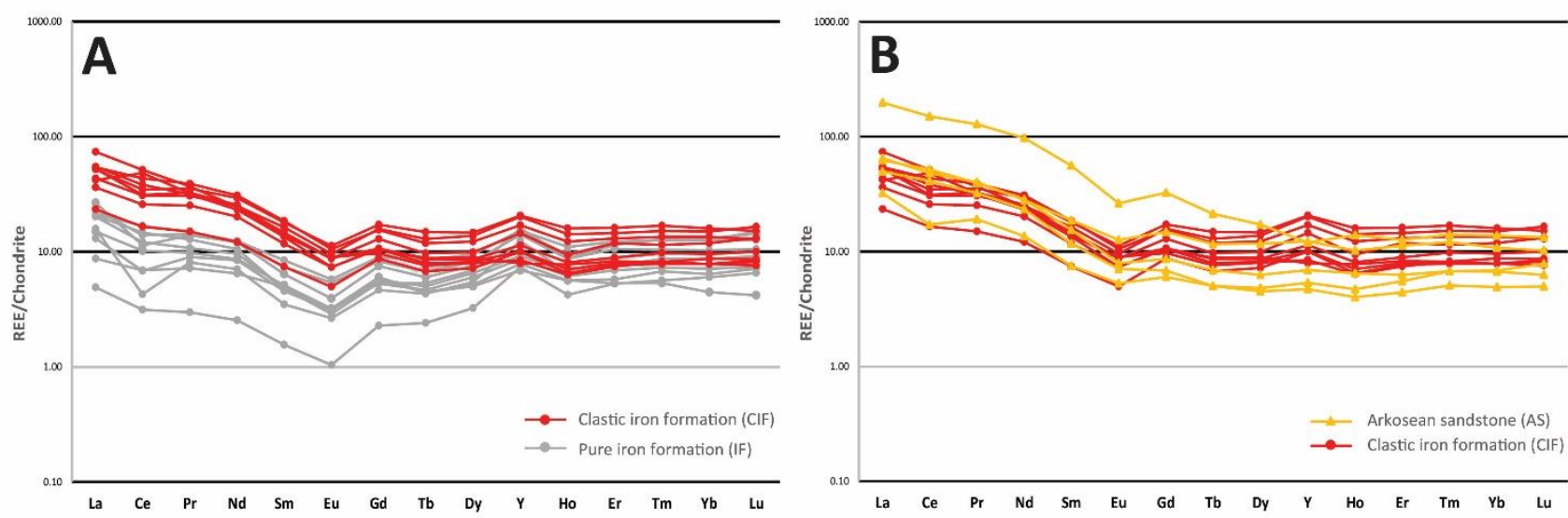

Figura 33 - Comparação dos padrões de ETRs e Y normalizados ao Condrito: (A) entre amostras de CIF e IF, (B) entre amostras de CIF e AS. 
O gráfico de padrão de ETR e Y normalizado ao condrito (Fig. 33) (Evensen et al.,1978) tem por finalidade mostrar a intensidade da anomalia de Eu das amostras analisadas. As amostras de formação ferrífera pura mostram fortes anomalias negativas de Eu e anomalias positivas de Y, que estão suavizadas nos grupos com contribuição clástica. Os elementos terras raras leves se encontram mais enriquecidos nos arenitos e nas formações ferríferas clásticas em comparação às formações ferríferas pura.

A distribuição global de todas as amostras analisadas permite observar o padrão de enriquecimento em ETR nas porções clásticas. No entanto esse enriquecimento não ocorre de maneira abrupta, mas transitória. As formações ferríferas com contribuição clástica evidenciam essa transição e apontam para o fato da deposição clástica ter se dado contemporaneamente a deposição química das formações ferríferas.

\subsection{Discussão}

A análise petrográfica permitiu identificar os processos que afetaram a sequência durante sua história evolutiva. Após a sedimentação química inicial da sílica e do ferro na forma de óxido e hidróxido respectivamente, o processo pós-deposicional mais primitivo evidenciado nas amostras está associado a uma possível dolomitização da sequência, indicado por cristais relictos de dolomita e anquerita que são encontrados em várias camadas de cherte. Indícios de processo de dolomitização já haviam sido citados por outros trabalhos na região (Angerer et al., 2016). A dolomitização, no entendimento do autor, seria responsável por gerar aumento da porosidade secundária na estrutura das rochas, permitindo que fluidos percolassem pela sequência.

Posteriormente à dolomitização, a circulação de fluidos ricos em sílica e ferro seriam responsáveis pelo aumento da concentração destes elementos nas rochas da bacia. Evidências da presença de fluidos ricos em sílica estão marcadas pela substituição de cristais e veios de dolomita, bem como nódulos, por sílica criptocristalina (cherte). Além da substituição de dolomita, análises de química mineral apontam para substituição de litoclastos e grãos minerais por cherte como mostram teores de $\mathrm{Al}$ presentes e grãos substituídos por cherte. Devido aos efeitos do aumento de porosidade durante a dolomitização, a sequência estaria susceptível a compactação, que resultaria em escape de fluidos, obliteração da porosidade, assim como deformação de estruturas como nódulos e pods. Além de expulsar fases e fluidos presentes nas rochas, a compactação seria capaz de aumentar a concentração de ferro por volume de material. 
Os eventos de enriquecimento em Fe estão claramente marcados pela gama de estruturas como nódulos e banda de cherte/jaspe substituídos por hematita que ocorre em hábitos variados (placosa "platy", maciça) e em diversos estágios evolutivos de substituição. O aspecto deformado dos veios que cortam as camadas ferruginosas, contrastante com o aspecto preservado dos mesmos veios quando atravessam camadas silicosas, mostra que as camadas ferruginosas tiveram resposta mais dúctil ou sofreram deformação de sedimentos moles em algum momento da sua história evolutiva. A deformação seletiva das camadas e a diferença da sua reposta à compactação pode estar associada a porosidade e dolomitização seletiva das camadas e/ou grau de formação do cherte nestes espaços.

Análise de MEV sobre amostras de hematita mostraram que a sílica presente em hematita é microcristalina e se encontra no interior deste mineral (Coffey, 2014). A presença de sílica no interior da hematita poderia ter duas origens: (a) uma origem hidrotermal dada pela percolação de fluidos ricos em sílica, em meio a porosidade existente ou que foi gerada durante a dolomitização da sequência, (b) e outra origem sin-deposicional, relacionada a deposição de sílica diretamente da água do mar rica neste elemento durante o Neoproterozoico. Essa questão ainda precisa ser debatida com análises específicas das porções silicosas.

Apesar de todos os processos pós-deposicionais (dolomitização, cristalização de sílica e hematita e desfluidização por compactação) que afetaram a sequência, alterações ou trocas químicas que resultariam em mudanças nos valores de elementos terras raras das amostras da Morraria Grande podem ser consideradas insignificantes, segundo Angerer et al. (2016). Outros autores (Bau \& Dulski 1996; Khalil et al., 2015) também se referem a processos sin- e pósdeposicionais como pouco capazes de afetar as concentrações de ETRs em formações ferríferas, e mesmo quando modificadas, as razões entre eles são mantidas.

Anomalias mais positivas de Y para as formações ferríferas puras mostram que estas rochas se aproximam do padrão de ETR da água do mar moderna em relação às formações ferríferas clásticas que apresentam anomalia positiva mais fraca. Tal argumento também é suportado pela presença de anomalia negativa de Ce e enriquecimento em ETRP (elementos terras raras pesados) em relação aos ETRL (elementos terras raras leves) semelhante ao padrão de ETRs da água do mar moderno. Apesar de anomalias negativas de Ce em formações ferríferas serem comumente atribuídas a presença de oxigênio nas águas em que foram depositadas (Bekker et al., 2010; Cox et al., 2013), Angerer et al. (2016) atentam para o fato de que fontes continentais podem ter contribuído para as assinaturas de Ce existentes. 
A comparação dos padrões de ETR em formações ferríferas das morrarias da região de Corumbá (Fig. 34 A) mostra padrões similares mas com grau de enriquecimento diferente entre as morrarias. As formações ferríferas "puras” da Morraria Grande apresentam as amostras mais enriquecidas em ETRL comparado as morrarias do Rabicho e do Urucum, sendo a última a mais depletada das três. A fácies de formação ferrífera clástica apresenta padrão de ETR similar as formações ferríferas clásticas encontradas na Bodoquena, sendo ligeiramente depletadas em ETRL em relação à esta.
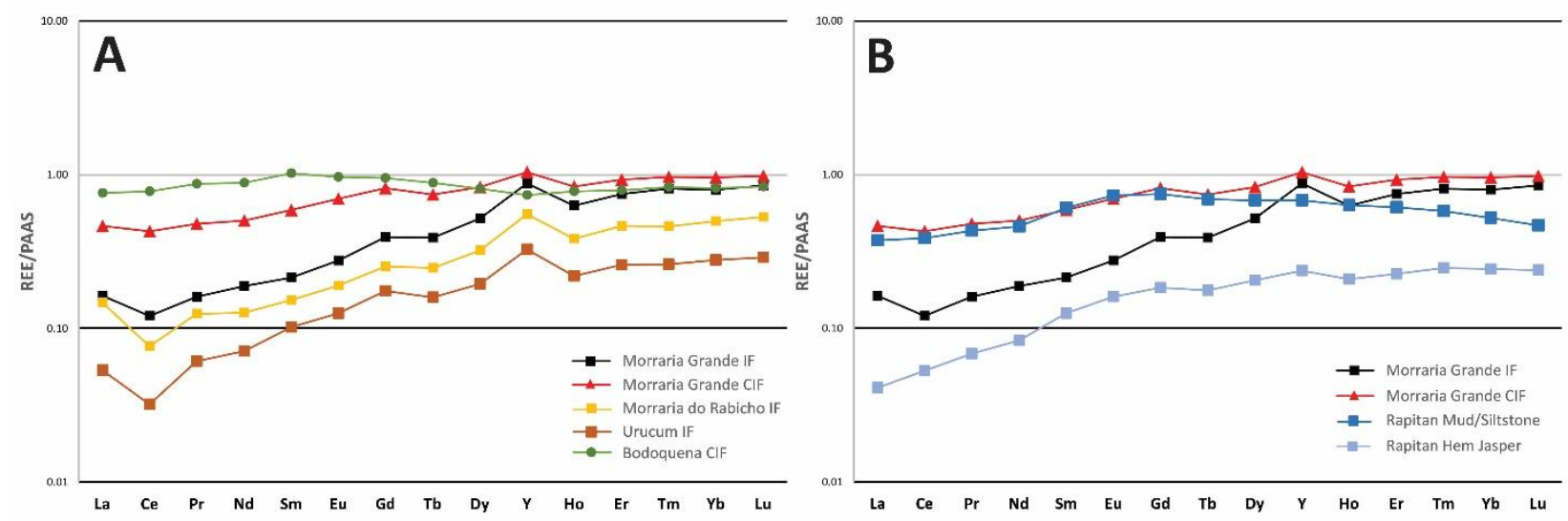

Figura 34 - Comparação dos padrões de ETRs e Y, (A) entre as formações ferríferas da Morrarias do Urucum, Morraria do Rabicho (Viehmann et al., 2016), Morraria Grande e da Bodoquena (Piacentini, 2008) (B) entre as formações ferríferas da Morraria Grande e do Grupo Rapitan, Canadá (Halverson et al., 2011).

Comparações entre as formações ferríferas da Morraria Grande e as formações ferríferas do Grupo Rapitan (Fig. 34 B) mostram que os padrões de ETR para a fácies clásticas das duas localidades são bastante parecidos, enquanto para as fácies sem contribuição clástica é mais depletada em ETR nas rochas do Grupo Rapitan. Estes dados mostram que provavelmente as formações ferríferas da Morraria Grande tiveram maior contribuição de elementos terras raras durante a sua deposição possivelmente associada ao seu posicionamento na margem da bacia e contribuição continental.

\subsubsection{Sobre as idades e modelos}

Apesar dos trabalhos publicados, existem ainda questionamentos quanto às relações estratigráficas das rochas do Grupo Jacadigo dentro da bacia e com as rochas da Faixa Paraguai, e em relação à sua idade de deposição (Angerer et al., 2016). Diversos modelos genéticos (Dorr II, 1945; Walde et al., 1981; Graf et al., 1994; Trompette et al., 1998; Dardenne, 1998; Dardenne \& Schobbenhaus, 2001; Klein \& Ladeira, 2004; Walde \& Hagemann, 2007; Freitas 
et al., 2011) foram propostos na tentativa de explicar a gênese das rochas do Grupo Jacadigo, porém não há consenso sobre o tema.

Os modelos genéticos para as formações ferríferas do Grupo Jacadigo são discutidos em detalhe por Walde \& Hagemann (2007), que também apontam a importância das feições hidrotermais e do enriquecimento secundário em Fe e Mn nas rochas da Membro Band'Alta. Walde \& Hagemann (2007) revisaram os 5 modelos genéticos anteriormente propostos e propõem um sexto modelo, mais aceito, que leva em conta o efeito da hipogênese para o enriquecimento em $\mathrm{Fe}$ e Mn, explicando assim os altos teores destes elementos nas camadas da sequência.

As datações obtidas até o momento não permitem estabelecer idades precisas para as rochas do Grupo Jacadigo, e somente limites mínimos para deposição podem ser interpretados. Idades de alterações e processos metamórficos que modificaram a mineralogia forneceram as idades mínimas para a formação do depósito. Datações pelo método ${ }^{40} \mathrm{Ar} /{ }^{39} \mathrm{Ar}$ em criptomelano das camadas de manganês, presentes na Morraria de Urucum, obtiveram idade de $587 \pm 7 \mathrm{Ma}$ (Piacentini et al., 2013), e marcam eventos secundários de alteração e metamorfismo de baixo grau, que afetaram a sequência.

Os limites máximos da idade da bacia, no momento, resumem-se às idades de granitos e gnaisses do embasamento (Piacentini et al., 2013). Hasui \& Almeida (1970) obtiveram idade de $889 \pm 44$ Ma pelo método K-Ar em granito do embasamento. No entanto, determinação mais precisa, feita pelo método U-Pb em zircão em amostra do Granito Taquaral, pertencente à Suíte intrusiva Alumiador, que compõe o embasamento próximo a Corumbá, indica idade de 1861+5,3 Ma (Redes et al., 2015). Diamictitos pertencentes à Formação Puga, logo ao sul de Corumbá, interpretada como contemporânea do Grupo Jacadigo (Angerer et al., 2016) mostraram idade máxima U-Pb em zircão detrítico de $706 \pm 9$ Ma (Babinski, 2011), equivalente à Glaciação Marinoana.

\subsection{Conclusão}

As formações ferríferas do Grupo Jacadigo na Morraria Grande mostram que na sua bacia de formação a sedimentação química ocorreu juntamente com o aporte de sedimentos clásticos. A prevalência da fácies nodular em detrimento da fácies bandada que ocorrem com espessas camadas de diamictito e as finas camadas de manganês que ocorrem somente em duas ocasiões sugerem uma região mais proximal para as rochas da Morraria Grande. Outro 
argumento que suporta essa interpretação são os padrões de ETRs das formações ferríferas desta localidade, que mostram maior enriquecimento em ETRs em comparação com as rochas das outras morrarias na região, o que sugere que essa parte da bacia recebeu maior aporte de sedimentos clásticos e possivelmente formava uma parte mais marginal da bacia.

As formações ferríferas puras da Morraria Grande mostram padrões de ETRs com características de contribuição por fluidos hidrotermais de baixa temperatura (ausência de anomalia de Eu) e similaridade com o padrão de ETRs da água do mar moderno (empobrecido em ETRL em relação aos ETRP). Anomalias negativas de Ce nas amostras analisadas sugerem condições oxidantes para o ambiente onde as rochas foram formadas.

A petrografia das amostras de formações ferríferas da sequência mostra que estas rochas processos de dolomitização e silicificação que causaram possível aumento de porosidade e facilitaram a percolação de fluidos hidrotermais. Então sugere-se aqui que as formações ferríferas do Grupo Jacadigo são o resultado de sucessivos processos de substituição em possível estágio diagenêtico que resultou na concentração de $\mathrm{Fe}$ e $\mathrm{Si}$ nos teores hoje encontrados. Estruturas de compactação também aparentam terem tido papel importante na concentração de Fe e retirada da fase fluida presente.

Os limites de deposição química anteriormente propostos para a Morraria do Urucum mostram aplicabilidade também às rochas da Morraria Grande, principalmente o limite na última camada de manganês ou de hematita bandada para marcar o limite de sequência e a separação dos membros Band'Alta e Córrego das Pedras, proposto por Dorr II (1945). Apesar de iniciais, as correlações geoquímicas e estratigráficas com os depósitos que ocorrem nas outras morrarias argumentam a favor de ampla diversidade de condições dentro da mesma bacia de deposição. 


\section{Síntese conclusiva e sugestões}

As formações ferríferas e rochas clásticas pertencentes ao Grupo Jacadigo na região da Morraria Grande, abordadas neste trabalho, mostraram registros das condições da água do mar em que foram precipitadas e de processos primários, sin- e pós-diagenéticos que afetaram a sucessão. Dados geoquímicos mostraram que as rochas foram formadas em um ambiente com presença de oxigênio e através de fontes hidrotermais de baixa temperatura. Após a deposição as rochas sofreram inúmeros processos de substituição e compactação que resultaram no aumento da concentração de ferro na sequência.

Em relação aos aspectos estratigráficos, os testemunhos de furos de sondagem na Morraria Grande mostraram que as formações ferríferas foram depositadas com espessos pacotes de diamictitos grossos intercalados. Além da dos espessos pacotes de diamictito a sequência da Morraria Grande difere das outras morrarias pela ausência de camadas representativas de manganês e pela forte presença da fácies nodular nas formações ferríferas. As rochas arcoseanas da base do Grupo Jacadigo estão dispostas sobre o embasamento granítico e gnáissico como ocorre nas outras morrarias e passam para a sequência sedimentar química de forma transicional.

Idades precisas para o depósito ainda não estão disponíveis e a ausência de rochas vulcânicas em meio a sequência dificultam a possibilidade de uma datação absoluta da sequência. Apesar das dificuldades em obter uma idade precisa para a sequência, os aspectos geológicos regionais e estruturais da Faixa Paraguai sugerem uma possível idade Marinoana para o depósito, por meio de correlação com diamictitos da Formação Puga. Estudos recentes chamam a atenção para possibilidade de idades ainda mais jovens.

Apesar de muitos trabalhos terem sido realizados sobre a geologia da região de Corumbá, as formações ferríferas nas outras morrarias ainda carecem de dados analíticos que contribuam para a correlação estratigráfica e o entendimento espacial dos aspectos da bacia onde foram depositadas. A ampliação destes trabalhos para as outras morrarias ajudaria a aumentar o detalhamento e o entendimento do contexto geológico regional da bacia. Entre os estudos que ainda podem ser feitos, se destacam:

- Estudos isotópicos de $\mathrm{Fe}, \mathrm{C}, \mathrm{S}$ e Nd, sobre as rochas ferríferas de cada morraria da região, objetivando detalhar e obter maior controle sobre as variações espaciais e químicas que ocorreram durante a sedimentação e história evolutiva das rochas. 
- Estudos litogeoquímicos sobre as formações ferríferas, apesar de dados litogeoquímicos terem sido obtidos no passado, o principal foco destes estudos foi as camadas de manganês. Reforça-se também que as tecnologias de análises moderna permitem maior precisão analítica, assim como o conhecimento sobre elementos terras raras. Por isso, estudos litogeoquímicos sobre as rochas ferríferas nas outras morrarias ainda se fazem importantes.

- Estudos isotópicos e geoquímicos em camadas, bandas e nódulos separados de sílica e hematita, para entendimento da origem e variações que possam ter ocorrido durante a sua formação. Apesar de análises de microssonda terem sido realizadas neste trabalho, não foi investigada a composição de elementos terras raras destas estruturas, e tal investigação se faria mais precisamente por outra metodologia.

- Levantamentos geofísicos (Gamaespectometria, Magnetometria e Gravimetria). Devido à grande cobertura de áreas pantanosas e a ação intensa de processos erosivos na região, o mapeamento e definição de contatos se tornam muito difíceis. Por isso levantamentos geofísicos poderiam ajudar a interpretar e definir melhor os contatos geológicos e estruturas na região. A região de Corumbá também é interpretada como localizada na junção entre o aulacógeno Tucavaca e a faixa de dobramentos Paraguai (Jones, 1985; D'el-Rey Silva et al., 2016). Por isso, levantamentos geofísicos regionais poderiam trazer importantes informações sobre a interação dessas duas grandes estruturas. 


\section{Referências Bibliográficas}

Almeida, F.F.M. 1945. Geologia do sudoeste mato grossense. Bol. Dep. Nac. Produç. Mineral (D.N.P.M.), Rio de Janeiro, Brasil, 116, 118 p.

Almeida, F.F.M. 1984. Província Tocantins - Setor Sudoeste. Em: Almeida, F.F.M. \& Hasui, Y. eds. O Pré-Cambriano do Brasil. Editora Blücher, São Paulo, Brasil, 265-281.

Alvarenga, C.J.S., Boggiani, P.C., Babinski, M., Dardenne, M.A., Figueiredo, M.F., Dantas, E.L., Uhlein, A., Santos, R.V., Sial, A.N., Trompette, R., 2011. Glacially influenced sedimentation of the Puga Formation, Cuiabá Group and Jacadigo Group, and associated carbonates of the Araras and Corumbá groups, Paraguay Belt, Brazil. Em: Arnaud, E., Halverson, G. P. \& Shields-Zhou, G. eds. The Geological Record of Neoproterozoic Glaciations. Geological Society, London. Memoirs, 36: 487-497.

Alvarenga, C.J.S., Moura, C.A.V., Gorayeb, P.S., de S., Abreu, de, F.A.M., 2000. Paraguay and Araguaia Belts. Em: Cordani, U.G., Milani, E.J., Thomaz Filho, A., Campos, D.A. eds. Tectonic Evolution of South America, 31 International Geological Congress, Rio de Janeiro, 183-193.

Alvarenga, C. J. S., Saes, G.S., 1992. Estratigrafia e sedimentologia do Proterozóico Médio e Superior da região sudeste do Cráton Amazônico. Revista Brasileira de Geociências, 22(4): 493-499.

Alvarenga, C.J.S., Trompette, R., 1992. Glacially-influenced sedimentation in the later Proterozoic of the Paraguay Belt (Mato Grosso Brazil). Palaeogeography, Palaeoclimatology, Palaeoecology, 92: 85-105.

Alvarenga, C. J. S., Trompette, R. 1993. Evolução tectônica Brasiliana da Faixa Paraguai: A estruturação da região de Cuiabá. Revista Brasileira de Geociências, 23: 18-30.

Angerer, T., Hagemann, S.G., Walde, D.H.G., Halverson, G.P., Boyce, A.J., 2016. Multiple metal sources in the glaciomarine facies of the Neoproterozoic Jacadigo iron formation in the "Santa Cruz deposit", Corumbá, Brazil. Precambrian Research, 275: 369-393.

Babinski, M., 2011. Geocronologia das glaciações criogenianas do Brasil Central. Tese de Livre Docência, Universidade de São Paulo, 190 p. 
Baldwin, G.J., 2014. The stratigraphy and geochemistry of the Rapitan iron formation, Northwest Territories and Yukon, Canada. PhD Thesis, Laurentian University, Ontario, Canada, 248 p.

Baldwin, G.J., Turner, E.C., Kamber, B.S., 2012. A new depositional model for glaciogenic Neoproterozoic iron formation: insights from the chemostratigraphy and basin configuration of the Rapitan iron formation. Canadian Journal of Earth Sciences, 49: 455-476.

Bau, M., Dulski, P., 1996. Distribution of yttrium and rare-earth elements in the Penge and Kuruman iron-formations, Transvaal Supergroup, South Africa. Precambrian Research, 79: 37-55.

Bekker, A., Slack, J.F., Planavsky, N., Krapež, B., Hofmann, A., Konhauser, K.O., Rouxel, O.J., 2010. Iron formation: The sedimentary product of a complex interplay among mantle, tectonic, oceanic, and biospheric processes. Economic Geology, 105: 467-508.

Campanha, G.A.C., Boggiani, P.C., Sallun Filho, W., Sá, F.S., Zuquim, M.P.S., Piacentini, T., 2011. A Faixa de Dobramento Paraguai na Serra da Bodoquena e Depressão do Rio Miranda, Mato Grosso do Sul. Revista do Instituto de Geociências - USP 11 3: 79-96.

Canfield, D.E., 1998. A new model for Proterozoic ocean chemistry. Nature, 396: 450-453.

Coffey, 2014. Relatório Consolidado de Campanha Exploratória 2012-2013, Jazida de Santa Cruz, Corumbá - MS. Coffey, Belo Horizonte, MG, 304 p.

Cordani, U.G., Brito Neves, B.B., Fuck, R.A., Porto, R., Thomaz Filho, A., Cunha, F.M.B., 1984. Estudo preliminar de integração do Pré-Cambriano com os eventos tectônicos das bacias sedimentares brasileiras. Ciência, Técnica, Petróleo. Seção Exploração de Petróleo, 15, 1-70.

Cordani, U.G., Brito-Neves, B.B., D, Agrella-Filho, M.S., 2003. From Rodinia to Gondwana: a review of the available evidence from South America. Gondwana Research 6 (2), 275 284.

Cox, G.M., Halverson, G.P., Minarik, W.G., Le Heron, D.P., Macdonald, F.A., Bellefroid, E.J., Strauss, J.V., 2013. Neoproterozoic iron formation: An evaluation of its temporal, environmental and tectonic significance. Chemical Geology, 369: 232-249. 
Dardenne, M.A., 1998. Modelo hidrotermal-exhalativo para os depósitos de Fe-Mn da região de Corumbá, Mato Grosso do Sul. Congresso Brasileiro de Geologia, Anais, São Paulo (SBG), 152.

Dardenne, M.A., Schobbenhaus, C., 2001. 3.7.2 - Faixa Paraguai: Distrito Fe-Mn de Urucum. Em: Dardenne, M.A., Schobbenhaus, C., eds. Metalogenese do Brasil, Editora Universidade de Brasília, 256-259.

Debacker, T.N., Sintubin, M., Verniers, J., 2001. Large-scale slumping deduced from structural and sedimentary features in the Lower Palaeozoic Anglo-Brabant fold belt, Belgium. Journal of the Geological Society, London, 150: 341-352.

D’el-Rey Silva, L.J.H., Walde, D.H.G., Saldanha, D.O., 2016. The Neoproterozoic-Cambrian Paraguay Belt, central Brazil: Part 1 - New structural data and a new approach on the regional implications. Tectonophysics, 676: 20-41.

Dimroth, E., Chauvel, J.J., 1973. Petrography of the Sokoman iron formation in part of the Central Labrador Trough, Quebec, Canada. Geological Society of America Bulletin, 84: 111-134.

Dorr II, J.V.N., 1945. Manganese and iron deposits of Morro do Urucum, Mato Grosso, Brazil. Geological Survey Bulletin, Washington, 946-A: 1-47.

Evans, J.W., 1894. The Geology of Matto Grosso. Geological Society of London, 50: 85-104.

Evensen, N.M., Hamilton, P.J., O’Nions, R.K., 1978. Rare earth abundances in chondritic meteorites. Geochimica et Cosmochimica Acta, 42: 1199-1212.

Eyles, C.H., Eyles, N., 2010. Glacial Deposits. Em: James, N.P., Dalrymple, R.W.. Facies Models 4. Geological Association of Canada IV, Series: GEOtext 6, Canada, 73-104.

Freitas, B.T., Warren, L.V., Boggiani, P.C., De Almeida, R.P., Piacentini, T., 2011. Tectonosedimentary evolution of the Neoproterozoic BIF-bearing Jacadigo Group, SW-Brazil. Sedimentary Geology, 238: 48-70.

Fuck, R.A., Brito Neves, B.B., Schobbenhaus, C., 2008. Rodinia descendants in South America. Precambrian Research 160: 108-126.

Graf, J.L., O’Connor, E.A., Van Leeuwen, P., 1994. Rare earth element evidence of origin and depositional environment of Late Proterozoic ironstone beds and manganese-oxide 
deposits, SW Brazil and SE Bolivia. Journal of South American Earth Sciences, 7(2): $115-116$.

Gaucher, C., Sial, A.N., Frei, R., 2015. Chemostratigraphy of Neoproterozoic Banded Iron Formation (BIF): Types, Ages and Origin. Em: Ramkumar, M. eds. Chemostratigraphy, Concepts, Techniques, and Applications. Elsevier, Amsterdan, Netherlands, 433-449.

Gross, G.A., 1980. Classification of iron formation based on depositional environments. Canadian Mineralogist, 18: 215-222.

Hagemann, S.G., Angerer, T., Duuring, P., Rosière, C.A., Figueiredo e Silva, R.C, Lobato, L., Hensler, A.S., Walde, D.H.G., 2015. BIF-hosted iron mineral system: A review. Ore Geology Reviews 76, 317-359.

Halverson, G.P., Poitrasson, F., Hoffman, P.F., Nédélec, A., Montel, J.M., Kirby, J., 2011. Fe isotope and trace element geochemistry of the Neoproterozoic syn-glacial Rapitan iron formation. Earth and Planetary Science Letters, 309: 100-112.

Haralyi, N.L.E., Walde, D.H.G., 1986. Os minérios de ferro e manganês da região de Urucum, Corumbá, Mato Grosso do Sul. Em: Schobbenhaus, C. e Coelho, C.E.S. eds. Principais Depósitos Minerais do Brasil, DNPM, Brasília, 2: 127-142.

Hasui, Y., Almeida, F.F.M., 1970. Geocronologia do centro-oeste brasileiro. Boletim da Sociedade Brasileira de Geologia, São Paulo, 19(1): 1-26.

Hoefs, J., Müller, G., Schuster, K.A., Walde, D., 1987. The Fe-Mn ore deposits of Urucum, Brazil: An oxygen isotope study. Chemical Geology, 65: 311-319.

Hoffman, P.F., 1991. Did the Breakout of Laurentia Turn Gondwanaland Inside-Out?. Science, 252: $1409-1412$.

Hoffman, P.F., Kaufman, A.J., Halverson, G.P. and Schrag, D.P., 1998. A Neoproterozoic snowball Earth. Science, 281: 1342-1346.

Hoffman, P. F., Li, Z.-X., 2009. A paleogeographic context for Neoproterozoic glaciation. Paleogeography, Paleoclimatology, Paleoecology, 277: 158-172.

Hoffman, P. F., Schrag, D. P., 2002. The snowball Earth hypothesis: testing the limits of global change. Terra Nova, 14: 129-155. 
Holland, H.D., 2006. The oxygenation of the atmosphere and oceans. Phil. Trans. R. Soc. B, 361: 903-915.

James, H.L., 1954. Sedimentary facies of iron-formation. Economic Geology, 49: 235-293.

James, N.P., Narbonne, G.M., Kyser, T.K., 2001. Late Neoproterozoic cap carbonates: Mackenzie Mountains, northwestern Canada: precipitation and global glacial meltdown. Canadian Journal of Earth Sciences, 38(8): 1229-1262.

Jones, J.P., 1985. The southern border of the Guaporé Shield in western Brazil and Bolivia: an interpretation of its geologic evolution. Precambrian Research, 28: 111-135.

Khalil, K.I., El-Shazly, A.E., Lehman, B., 2015. Late Neoproterozoic banded iron formation (BIF) in the central Eastern Desert of Egypt: Mineralogical and geochemical implications for the origin of the Gebel El Hadid iron ore deposit. Ore Geology Reviews 69, 380-399.

Kirschivink, J.L. 1992. Late Proterozoic low-latitude global glaciation: the snowball earth. Em: Schopf, J.W., Klein, C. eds. The Proterozoic biosphere: a multidisciplinary study. Cambridge University Press, Cambridge, UK., 51-52.

Klein, C., 2005. Some Precambrian banded iron-formations (BIFs) from around the world: Their age, geologic setting, mineralogy, metamorphism, geochemistry, and origin. American Mineralogist, 90: 1473-1499.

Klein, C., Beukes, N.J., 1993. Sedimentology and geochemistry of the glaciogenic late Proterozoic Rapitan iron-formation in Canada. Economic Geology and the Bulletin of the Society of Economic Geologists, 88(3): 542-565.

Klein, C., Ladeira, E.A., 2004. Geochemistry and mineralogy of Neoproterozoic ironformations and some selected, siliceous manganese formations from the Urucum District, Mato Grosso do Sul, Brazil. Economic Geology, 99: 1233-1244.

Lascelles, D.F., 2013. Plate tectonics caused the demise of banded iron formations. Applied Earth Science (Trans. Inst. Min, Metall. B), 122: 230-241.

Li, Z. X., Bogdanova, S. V., Collins, A. S., Davidson, A., De Waele, B., Ernst, R. E., Fitzsimons, I. C. W., Fuck, R. A., Gladkochub, D. P., Jacobs, J., Karlstrom, K. E., Lu, S., Natapov, L. M., Pease, V., Pisarewsky, S. A., Thrane, K., and Vernikovsky, V., 2008, 
Assembly, configuration, and break-up history of Rodinia: A synthesis: Precambrian Research, 160: 179-210.

Lisboa, M.A.R., 1909. Oeste de São Paulo, Sul do Mato Grosso; geologia, indústria mineral, clima, vegetação, solo agrícola, indústria pastoril. Estrada de Ferro Noroeste do Brasil, Rio de Janeiro, Typ do Jornal do Commercio, 1-172.

Macdonald, F.A., Schmitz, M.D., Crowley, J.L., Roots, C.F., Jones, D.S., Maloof, A.C., Strauss, J.V., Cohen, P.A., Johnston, D.T., Schrag, D.P., 2010. Calibrating the Cryogenian. Science, 327(5970): 1241-1243.

Mantovani, M.S.M., Quintas, M.C.L., Shukosky, W., Brito Neves, B.B., 2005. Delimitation of the Paranapanema Proterozoic block: A Geophysical Contribution. Episodes, 28(1): 1822.

Mantovani, M.S.M., Brito Neves, B.B., 2010. The Parapanema lithospheric block: Its nature and its role in the fusion of Gondwana. Em: C. Gaucher, A.N. Sial, G.P. Halverson, H.E. Frimmel (Org.). Developments in Precambrian Geology: Neoproterozoic-Cambrian tectonics, global change and evolution: a focus on southwestern Gondwana. Amsterdam: Elsevier, 257-272.

McLennan, S.B., 1989. Rare Earth elements in sedimentary rocks: influence of provenance and sedimentary processes. Geochemistry and mineralogy of the rare earth elements. Reviews in Mineralogy and Geochemistry, 21: 169-200.

McLennan, S.M., Taylor, S.R., 2012. Geology, Geochemistry, and Natural Abundances of the Rare Earth Elements. Em: Atwood, D.A. eds. The rare earth elements: fundamentals and Applications. John Wiley \& Sons Ltd, $1^{\text {a }}$ edição, 1-19.

Planavsky, N., Bekker, A., Rouxel, O.J., Kamber, B., Hofmann, A., Knudsen, A., Lyons, T.W., 2010. Rare Earth Element and yttrium compositions of Archean and Paleoproterozoic Fe formations revisited: New perspectives on the significance and mechanisms of deposition. Geochimica et Cosmochimica Acta, 74: 6387-6405.

Piacentini, T., 2008. A formação ferrífera da Formação Puga: Avaliação regional dos recursos da Serra da Bodoquena, MS. Dissertação de Mestrado, Universidade de São Paulo, Instituto de Geociências, 106 p. 
Piacentini, T., Vasconcelos, P.M., Farley, K.A., 2013. 40Ar/39Ar constraints on the age and thermal history of the Urucum Neoproterozoic banded iron-formation, Brazil. Precambrian Research, 228: 48-62.

Redes, L.A.; Souza, M.Z.A.; Ruiz, A.S.; Lafon, J.M.; 2015. Petrogenesis and U-Pb and Sm-Nd geochronology of the Taquaral granite: record of an orosirian continental magmatic arc in the region of Corumbá-MS. Brazilian Journal of Geology, 45: 431-451.

Rollinson, H., 1993. Using geochemical data: evaluation, presentation, interpretation. Routledge, Taylor \& Francis Group, 352 p.

Sial, N.S., Campos, M.S., Gaucher, C., Frei, R., Ferreira, V.P., Nascimento, R.C., Pimentel, M.M., Pereira, N.S., Rodler, A., 2015. Algoma-type Neoproterozoic BIFs and related marbles in Seridó Belt (NE Brazil): REE, C, O, Cr and Sr isotope evidence. Journal of South American Earth Sciences, 61: 33-52.

Stern, R.J., Mukherjee, S.K., Miller, N.R., Ali, K., Johnson, P.R., 2013. 750 Ma banded iron formation from the Arabian-Nubian Shield-implications for understanding Neoproterozoic tectonics, volcanism, and climate change. Precambrian Research, 239: 79-94.

Trompette, R., Alvarenga, C.J.S., Walde, D., 1998. Geological evolution of the Neoproterozoic Corumba graben system (Brazil). Depositional context of the stratified Fe and Mn ores of the Jacadigo Group. Journal of South American Earth Sciences, 11: 587-597.

Urban, H., Stribrny, B. and Lippolt, H. (1992). Iron and manganese deposits of the Urucum district, Mato Grosso do Sul, Brazil. Econ. Geol., 87: 1375-1392.

Viehmann, S., Bau, M., Bühn, B., Dantas, E.L., Andrade, F.R.D., Walde, D.H.G., 2016. Geochemical characterisation of Neoproterozoic marine habitats: Evidence from trace elements and $\mathrm{Nd}$ isotopes in the Urucum iron and manganese formations, Brazil. Precambrian Research, 282: 74-96.

Vilela, F.T., 2010. Caracterização de metadiamictitos ferruginosos da Formação Nova Aurora (Grupo Macaúbas, Orógeno Araçuaí) a oeste de Salinas, MG. Dissertação de Mestrado, Universidade Federal de Minas Gerais, Instituto de Geociências, 135 p. 
Walde, D.H.G., 1988. Das Proterozoische Paraguay-Araguaia orogen in West-Brasilien, ausgehend von untersuchungen im Raum Corumbá. Habilitationsschrift, AlbertLudwigs Univ., Freiburg, 122 p. unpublished.

Walde, D.H.G., Gierth, E., Leonardos, O.H., 1981. Stratigraphy and mineralogy of the manganese ores of Urucum, Mato Grosso, Brazil. Geologische Rundschau, 70: 10771085.

Walde, D.H.G., Hagemann, S.G., 2007. The Neoproterozoic Urucum/Mutún Fe and Mn deposits in W-Brazil/SE-Bolivia: assessment of ore deposit models. Z. dt. Ges. Geowiss., 158(1): 44-55.

Weiss, M.P., Sweet, W.C., 1959. Stratigraphy and structure of the Mutum mountains, Department of Santa Cruz, Bolivia. Em: Congresso Geológico Internacional, México. Seção 13, Geologia Aplicada, 399-413.

Xu, D.R., Wang, Z.L., Chen, H.Y., Hollings, P., Jansen, N.H., Zhang, Z.C., Wu, C.J., 2013. Petrography and geochemistry of the Shilu $\mathrm{Fe}-\mathrm{Co}-\mathrm{Cu}$ ore district, South China: Implications for the origin of a Neoproterozoic BIF system. Ore Geology Reviews, 57: 322-350.

Young, G.M., 1976. Iron-formation and glaciogenic rocks of the Rapitan Group, Northwest Territories, Canada. Precambrian Research, 3: 137-158.

Ziegler, P.A. 1959. Frühpaläozoiche Tillite im östlichen Yukon-Territorium (Kanada). Eclogae Geologicae Helvetiae, 52(2): 735-741. 


\section{ANEXO A}

Resumo em anais 


\title{
XIV Simpósio de Geologia do Centro-Oeste
}

Província Tocantins - 50 Anos de Geologia

06 a 09 de Setembro de 2015 | Brasilia - DF

\section{Novas observações sobre o Grupo Jacadigo na região de Morraria Grande, sul da Faixa Paraguai}

\author{
Saldanha, D.O. ${ }^{1}$; Fuck, R.A. ${ }^{1}$; Walde, D.H.G. ${ }^{1}$
}

\begin{abstract}
${ }^{1}$ Instituto de Geociências, Universidade de Brasília
saldanhadavi@gmail.com
\end{abstract}

\section{Resumo}

O Grupo Jacadigo corresponde a sequências sedimentares depositadas no Neoproterozóico, na porção sul da Faixa Paraguai. Trabalhos anteriores propõem a deposição do grupo em sistema de meio graben, definido como Graben de Corumbá, que posteriormente sofreu processo de inversão tectônica. Recentemente, novos dados obtidos de furos, permitiram associar rochas Grupo Jacadigo que ocorrem na Morraria Grande às unidades antes descritas por autores na Morraria do Urucum. Tais correlações ajudam a posicionar verticalmente os estratos sedimentares da Morraria Grande em relação as outras morrarias, e contribuem para o argumento da uma extensa continuidade lateral das camadas na região.

\section{Introdução}

Distribuído no oeste do Mato Grosso do Sul, na fronteira Brasil-Bolívia (Fig.1), o Grupo Jacadigo (Almeida, 1945) corresponde a espesso pacote sedimentar depositado sobre rochas do embasamento granito-gnáissico Paleoproterozóico da região. As rochas que constituem o grupo têm especial importância por conterem grande variedade de tipos litológicos, que incluem formações ferríferas e diamictitos da Formação Santa Cruz e rochas siliciclásticas e arcoseanas da Formação Urucum que estão em contato com o embasamento cristalino.

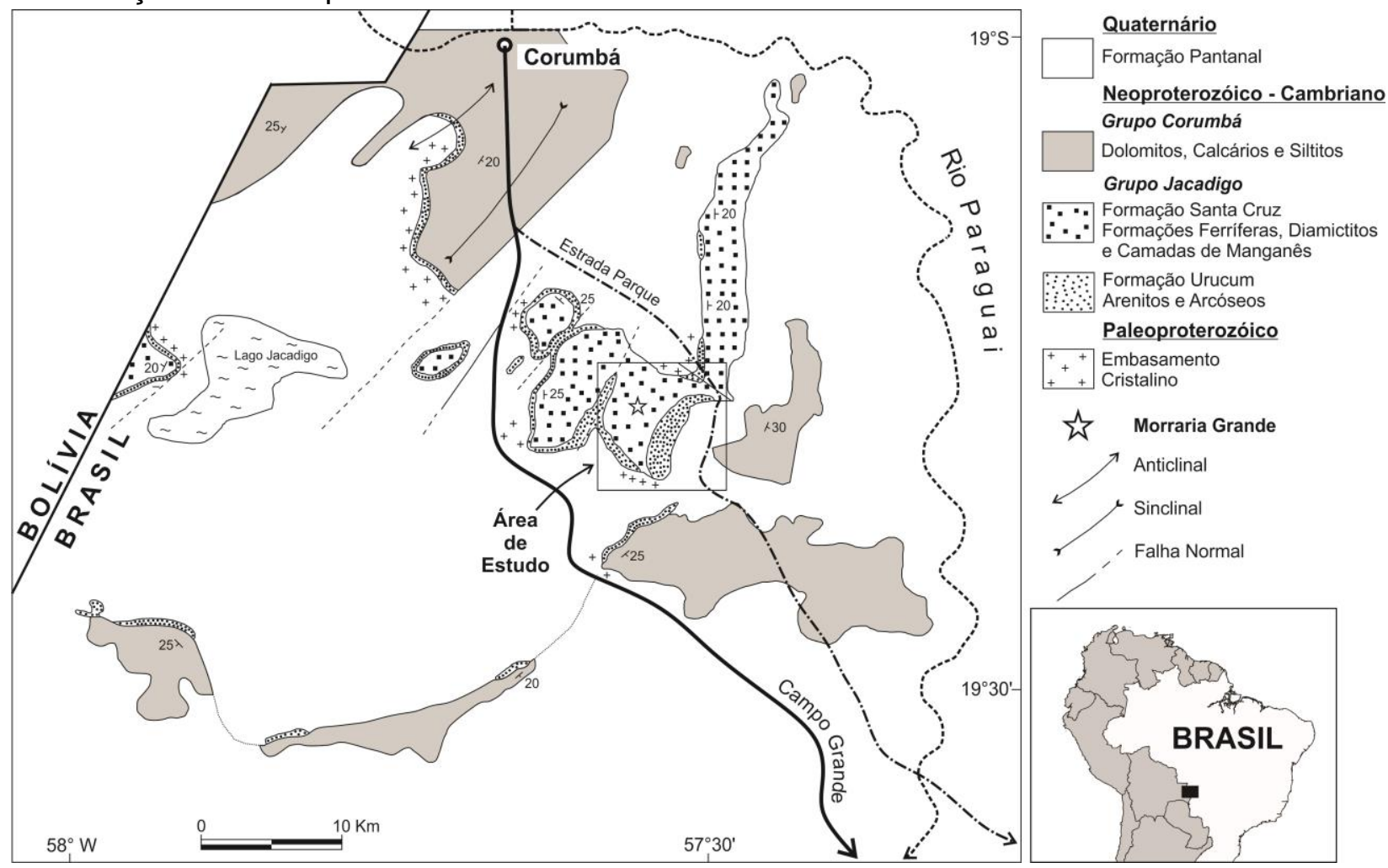

Fig. 1 - Mapa Geológico da região de Corumbá, adaptado de Walde (1988) 
Saldanha, D.O. ${ }^{1}$; Fuck, R.A. ${ }^{2}$; Walde, D.H.G. ${ }^{3}$

O presente resumo apresenta novos dados estratigráficos preliminares para as rochas do Grupo Jacadigo, e tendo como objeto de análise a região da Morraria Grande e da Morraria do Urucum, a sudeste da cidade de Corumbá (MS).

\section{Dados estratigráficos}

Dados obtidos em furos de sondagem permitiram caracterizar estratigraficamente as rochas do Grupo Jacadigo, em especial as rochas da Formação Santa Cruz e seus contatos com as rochas abaixo. Os dados coletados na região de Morraria Grande, última das morrarias a sudeste de Corumbá, demonstram que as rochas da Formação Santa Cruz se apresentam muito pouco deformadas, exceto por estruturas rúpteis e zonas de falhas localizadas em certas porções.

A estratigrafia observada na região de Morraria Grande teve início com a deposição de sedimentos siliciclásticos e arcoseanos da Formação Urucum, recobrindo boa parte do embasamento gnáissico e granítico de coloração rosada. As unidades muitas vezes apresentam porções do embasamento retrabalhado na base dos seus pacotes sedimentares, possivelmente representando uma superfície de discordância erosiva sobre o embasamento. Em algumas localidades, nas partes mais altas da morraria, o empilhamento estratigráfico se inicia diretamente com rochas da base da Formação Santa Cruz.

A Formação Santa Cruz, definida por Almeida (1945), é dividida por Dorr II (1945) em duas unidades, Formação Córrego das Pedras (FCP) na porção inferior, e Formação Band'Alta (FBA) na porção superior. Na região em estudo, a FCP é composta por rochas siliciclásticas médias a grossas, com certa quantidade de ferro e/ou manganês distribuído, especialmente próximo ao contato com o embasamento. O modo disperso do ferro e manganês nessa formação confirma um caráter transicional entre a Formação Urucum e a Formação Santa Cruz, como proposto por Dorr II (1945).

A Formação Band'Alta (FBA) representa a maior espessura dentro do Grupo Jacadigo e corresponde à unidade que se encontra em maior altitude na região (Dorr II, 1945). A FBA é composta essencialmente por formações ferríferas bandadas hematíticas, com presença de camadas de arenitos arcoseanos finos a médios na base, que dão lugar a pacote espesso de formações ferríferas bandadas maciças com carbonato até profundidades de 90-100 m. Nesse pacote são observadas camadas intercaladas de diamictitos de espessuras variáveis entre intervalo de 1 a 8 metros. Acima das formações ferríferas maciças prevalecem formações ferríferas nodulares, que quando preservadas demonstram nódulos siltosos centimétricos avermelhados. Os nódulos possuem em geral formas elipsoidais com centro muitas vezes ainda arredondado, e, quando preservados, contém pequenas quantidades de carbonato. As formações ferríferas nodulares do topo da sequência estão bastante lixiviadas, o que muitas vezes confere aspecto de queijo suíço às rochas. Camadas de diamictitos são frequentes dentro das formações ferríferas nodulares da porção superior; devido à alteração nessas zonas mais rasas, o material muitas vezes se apresenta como amorfo, sendo diferenciado pela coloração e pela presença de fração siliciclástica fina e pela química.

A última parte da sequência, e maior parte do que recobre a Morraria Grande, consiste em espessas capas de elúvios e colúvios que podem chegar até $10 \mathrm{~m}$ de profundidade no perfil. Os colúvios e elúvios representam o material de maior teor para exploração na região, devido à alta lixiviação de sílica. Os colúvios são bastante variados, com química complexa devido à processos intempéricos. O material demonstra maior espessura próximo a vales e encostas das morrarias.

As camadas de manganês aparecem de 3 a 4 vezes distribuídas pela extensão da Formação Santa Cruz, e muitas vezes correspondem a sequências siliciclásticas finas, ou até mesmo a formações ferríferas-manganesíferas. Nas porções superiores observam-se resquícios de manganês em alguns níveis dispersos no pacote, e a remobilização para os limites de alteração do pacote. A camada de manganês mais próxima da base da sequência da formação foi 
Saldanha, D.O. ${ }^{1}$; Fuck, R.A. ${ }^{2}$; Walde, D.H.G. ${ }^{3}$

encontrada em várias ocasiões durante o levantamento, o que confere certo grau de confiabilidade para correlações estratigráficas na região.

\section{Discussão}

Os estudos de detalhe sobre as rochas da Formação Band'Alta, e as relações com os dados de trabalhos realizados sobre as rochas localizadas nas outras morrarias, permite o início das correlações estratigráficas na região. Limites de sequência anteriormente propostos demonstram aplicabilidade também nas rochas da Morraria Grande, principalmente em relação ao limite das formações Band'Alta e Córrego das Pedras, que Dorr II (1945) propôs ser posicionado na última camada de manganês da sequência ou de hematita bandada.

As formações ferríferas descritas como bandadas e nodulares ainda carecem de dados publicados em suas outras localidades de ocorrência que permitam uma correlação estratigráfica das texturas na região. No entanto algumas estruturas descritas por Dorr II (1945) sobre as rochas da Formação Band'Alta, como sendo de possível origem orgânica também foram evidenciadas em afloramentos na região da Morraria Grande, tais estruturas não são identificadas em profundidade devido as limitações dos testemunhos.

Os diamictitos que ocorrem intercalados as formações ferríferas da região, já apresentam característica geográfica mais limitada pela possível ocorrência na forma de lentes extensas 1$2 \mathrm{~km}$ de extensão e espessura de que chegam até 15 metros nas porções mais espessas e mais rasas da sequência.

Apesar de iniciais, tais correlações com os depósitos que ocorrem nas outras morrarias, argumentam a favor de uma ampla continuidade lateral das camadas de formação ferrífera dentro da bacia de deposição da Formação Band'Alta.

\section{Agradecimentos}

Os autores gostariam de expressar os agradecimentos à Vetorial Mineração pelo suporte aos trabalhos de campo, e a sempre prestativa recepção dos autores nas dependências da sua mina. Agradecimentos também são direcionados à CAPES pela disponibilização da bolsa de mestrado que possibilitou a execução do presente trabalho.

\section{Referências}

Almeida F.F.M. 1945. Geologia do sudoeste mato grossense. Bol. Dep. Nac. Produç. Mineral (D.N.P.M.), Rio de Janeiro, Brasil, 116, 118 p.

Dorr II J.V.N. 1945. Manganese and iron deposits of Morro do Urucum, Mato Grosso, Brazil. Bull. U.S. Geol. Surv. 946A, 47 p.

Walde D.H.G. 1988. Das Proterozoische Paraguay-Araguaia orogen in West-Brasilien, usgehend von untersuchungen im Raum Corumbá. Habilitationsschrift, Albert-Ludwigs Univ., Freiburg,122 p. unpublished. 
ANEXO B

Artigo Publicado 


\title{
The Neoproterozoic-Cambrian Paraguay Belt, central Brazil: Part I - New structural data and a new approach on the regional implications
}

\author{
Luiz José Homem D'el-Rey Silva *, Detlef Hans-Gerd Walde, Davi Oliveira Saldanha \\ Universidade de Brasília, Instituto de Geociências, Brasília, DF, Brazil
}

\section{A R T I C L E I N F O}

\section{Article history:}

Received 5 July 2015

Received in revised form 8 March 2016

Accepted 14 March 2016

Available online 25 March 2016

\section{Keywords:}

Structural analysis

Jacadigo and Corumbá Groups

Paraguay belt

R-R-R system

Regional geology

\begin{abstract}
A B S T R A C T
Together with the Araguaia and Brasília belts, the Paraguay belt forms in central Brazil, the Tocantins Province that is one of the largest orogens of western Gondwana. The Corumba area occupies the site where the northern and southern parts of the Paraguay belt form, together with the Chiquitos-Tucavaca aulacogen (stretching E-W in the adjacent Bolivian territory) an R-R-R basin system opened-filled in the 700/650-540 Ma interval within the Amazon-Rio Apa paleo-continent. The sedimentary (volcanic) rocks of the Jacadigo and Corumbá Groups found around the Corumbá city record part of the Neoproterozoic-Cambrian passive margin precursor of the Paraguay belt. Our pioneer structural analysis reveals that these rocks experienced progressive deformation (phases $\mathrm{D}_{1}-\mathrm{D}_{2}-\mathrm{D}_{3}$ ) and low-grade metamorphism during the Brasiliano Cycle (540-513 Ma). The crystalline basement was also involved, according to structural data and $\mathrm{K}-\mathrm{Ar}$ ages in the literature. The paleo-passive margin was thickened during the $D_{1}-D_{2}$ deformation and was lately shortened $\left(D_{3}\right)$ in two orthogonal directions, SE$N W\left(D_{3 P}\right)$ and SW-NE $\left(D_{3 T}\right)$. Developed co-axially and verging to $N W, D_{1}-D_{2}-D_{3 P}$ structures record the closure of the basin precursor of the Paraguay belt, whereas $\mathrm{D}_{3 \mathrm{~T}}$ structures seem related to the inversion of the aulacogen. Although the tectonic transport to NW, as observed in the Corumbá area, matches the reported transport of Paraguay belt's supracrustal rocks towards the eastern margin of the Rio Apa block and Araguaia belt's rocks towards the Amazon craton, the transport direction is opposite in other parts of the Paraguay belt. Our comprehensive discussion of these facts brings to light profound regional implications.
\end{abstract}

(c) 2016 Elsevier B.V. All rights reserved.

\section{Introduction}

In the surroundings of Corumbá (Fig. 1), a large city on the western banks of the Paraguay River, central Brazil, the substratum includes Neoproterozoic-Cambrian (meta)sedimentary/volcanic rocks (Jacadigo and Corumbá Groups) plus metamorphic/igneous rocks of the crystalline basement (Jones, 1985; Walde, 1988). According to these authors and many others (e.g. Ruiz, 2005; Cordani et al., 2010) from Corumbá the Neoproterozoic-Cambrian rocks stretch into three belts which record the arms of an ancient R-R-R rift basin and the amalgamation of western Gondwana in central Brazil. The NNE-trending northern Paraguay belt stretches towards the city of Cuiabá; the southern Paraguay belt stretches SSE towards the city of Bonito, following along the eastern margin of the Rio Apa block (where is the Bodoquena Range); and the WNW-trending Chiquitos-Tucacava (or Tucavaca) aulacogen stretches WNW of Puerto Suarez, into the Bolivian territory (Fig. 1b).

\footnotetext{
* Corresponding author at: Instituto de Geociências, Universidade de Brasília, Campus Darcy Ribeiro, CEP 70.910-900, Brasília, DF, Brazil. Tel.+55 6199962812.

E-mail addresses: ldel-rey@unb.br, luizhomemsilva@yahoo.com.br (L.J.H.D.-R. Silva).
}

Such template points to the basin precursor of the Paraguay belt as established along the Amazon-Rio Apa passive continental margin (Ruiz, 2005; and references therein).

The Corumbá area, famous worldwide for the swamp named Pantanal, is geologically relevant because: (1) - the large reserves of Fe-Mn ore contained in Jacadigo Group rocks; (2) - the Paraguay belt and the R-R-R system integrate, together with the Araguaia and Brasilia belts, the Tocantins Province (Almeida et al., 1981), the large collisional orogen which originated during the Brasiliano Cycle orogeny (Fig. 1a; Trompette, 1994); (3) - because the Paraguay belt was the last to form, its evolution must be linked to a series of events responsible for the Brasília and Araguaia belts, therefore a better geological understanding of the Corumbá area should help unraveling the final moments of amalgamation of western Gondwana in central Brazil; and (4) - the Corumbá Group carbonate platform corresponds laterally to the Araras Group platform mapped further North, in the Cuiabá area of the Paraguay belt, and these are age- and lateral-equivalent to the 540 Ma-old carbonate platform (Tocantins Group) that occurs obducted by the $\sim 750$ Ma-old Quatipuru ophiolite in the westernmost part of the Araguaia belt, indicating the continuation of the Quatipuru Ocean to the south, into the basin precursor of the Paraguay belt (Paixão et al., 2008).

Nevertheless, despite of its importance, and after the pioneer regional-scale work by Dorr (1944), the Corumbá area has been the 


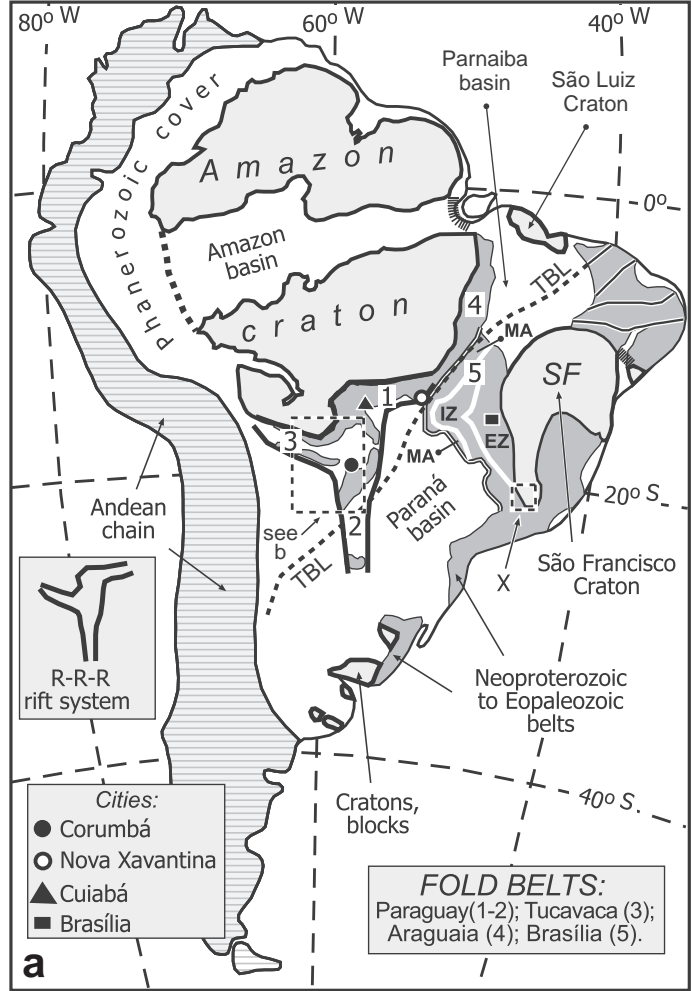

Archean - Paleoproterozoic

Cristalline Basement (Amazon craton and Rio Apa block)

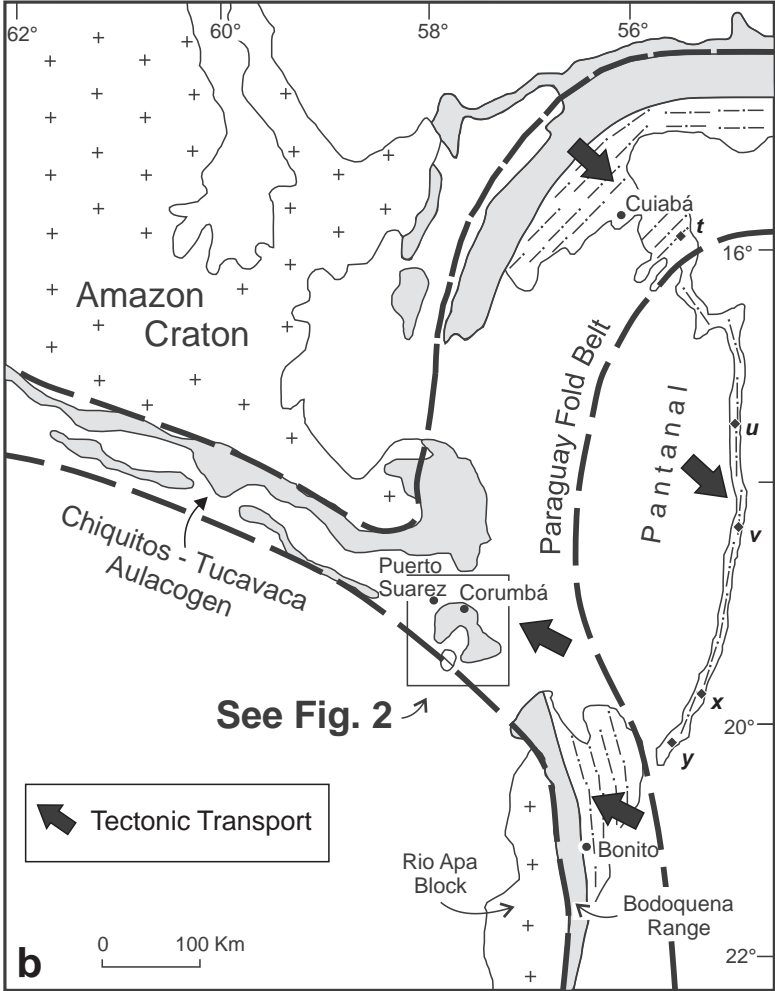

Neoproterozoic

Cratonic cover rocks Margin Basin Rocks

(Cuiabá Group)

\section{Phanerozoic}

Cover Rocks $+{ }_{+}^{+}$

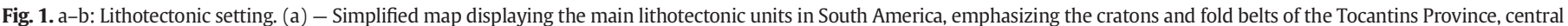

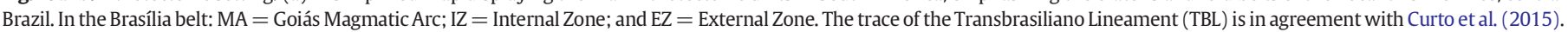

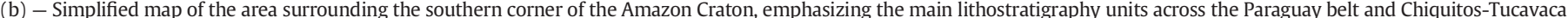

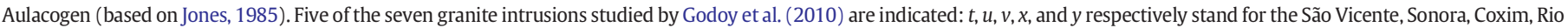
Negro, and Taboco granites. The Laginha and Araguaiana granites occur outside this map, in the Nova Xavantina area (Fig. 1a). See text for the directions of tectonic transport.

focus of studies devoted basically to the detailed description of the lithostratigraphy units and the fossil record (Walde, 1988; Trompette et al., 1998; Walde et al., 2015) or to sedimentology and geochronology details (e.g., Boggiani et al., 2010; Piacentini et al., 2013) therefore leaving open an entire field for detailed structural/tectonic analysis.

This paper results from the detailed structural study carried out upon the Jacadigo and Corumbá rocks of the Corumbá area, and is particularly necessary should the style of deformation/metamorphism of the rocks along the Amazon-Rio Apa paleo-continental margin be understood. It presents a large amount of structural data collected (2012-2013) in tens of outcrops situated inside the VETRIA Mine (one of the private properties in which the local Fe-Mn reserves are divided) and in outcrops of Corumbá Group rocks, the most relevant of which are being localized in Fig. 2. The structures and their mutual relationships are clear enough for a simple and straightforward interpretation. Our studies unravel the post-sedimentation evolution of the rocks in the Jacadigo and Corumbá Groups according to a poly-phase $\left(D_{1}-D_{2}-D_{3}\right)$ contraction deformation associated to a very low-grade metamorphism, and were accompanied in the last stage by additional studies (Angerer et al., 2015) focusing specifically on the microscopic aspects of deformation and the role of fluids for the Fe mineralization in the Santa Cruz deposit (VETRIA Mine).

Our structural data and others' geology/geochronology data indicate evolution late in the Brasiliano Cycle orogeny, 540-518/513 Ma ago.

However, different to other structural studies (comments and references in Section 4.2) our results require a detailed discussion on the tectonic evolution of the Tocantins Province. This new approach starts with a comprehensive discussion of our and others' structural data across the Paraguay belt and the regional implications of such data (Part I; this paper) and ends with a detailed discussion on the origin of the Paraguay basin and on how it might have been positively inverted (Part II; companion paper).

\section{Regional setting}

\subsection{Few words on the Tocantins Province}

The Tocantins Province derives from the tectonic interaction of the Amazon (Amazon-Rio Apa) and São Francisco paleo-continents with participation of the Parnaíba and Paraná continental blocks and underlying lithospheric mantle shown to exist respectively under the Parnaíba basin (Ussami and Molina, 1999; Castro et al., 2014) and Paraná basin (Mantovani and Brito Neves, 2005; Fig. 1a).

According to Fuck et al. (1994, 2006) the Brasília belt is commonly divided in three domains parallel to western margin of the São Francisco craton (Fig. 1a): the Goiás Magmatic Arc, the Internal Zone, and the External Zone. The arc comprises oceanic island rocks derived from the 900-650/640 Ma consumption of the Goiás Ocean plus sediments of back-arc basins adjacent to the western margin of the São Francisco paleo-continent (Pimentel et al., 2000). The Internal Zone encloses slices of granulite facies tectonites within (amphibolite-)greenschist facies supracrustal rocks (garnet-mica schist) of napes derived from the back-arc basin and, locally, a mélange of M-Um rocks. The part of the Internal Zone salient to the west (about the latitude of Brasília; Fig.1a) 

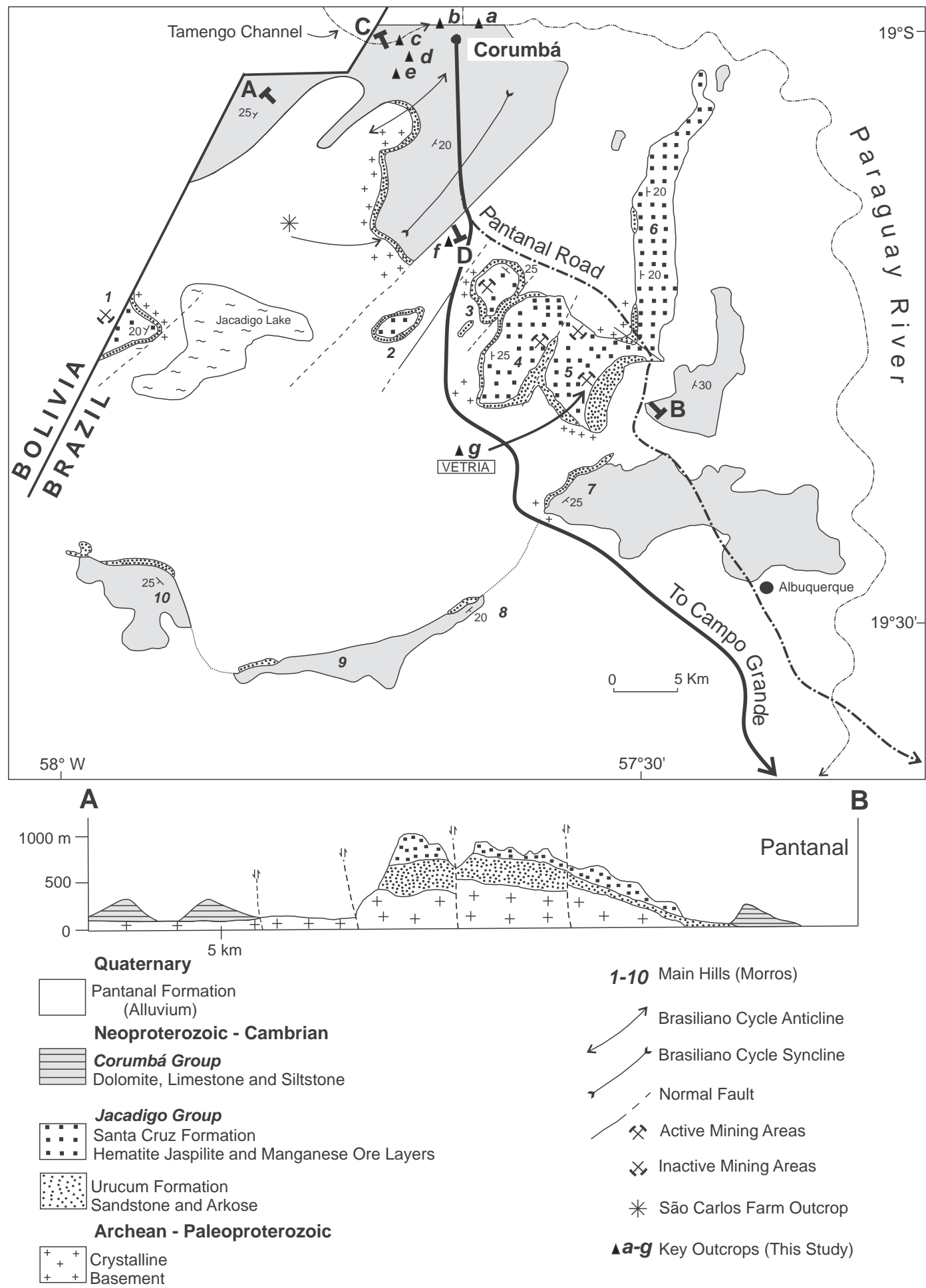

B

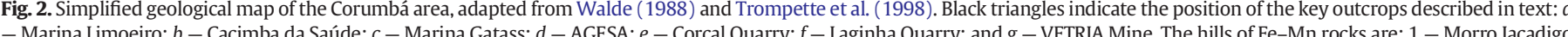
- Cacimba da Saúde; $c$ - Marina Gatass; $d$-AGESA; $e$ - Corcal Quarry; $f$ - Laginha Quarry; and $g$ - VETRIA Mine. The hills of Fe-Mn rocks are: 1 - Morro Jacadigo

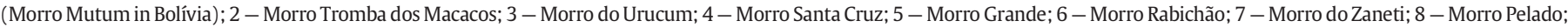
9 - Morro d'Aguassu; and 10 - Morro Sajutá. Note the line of the geological section CD (Fig. 5) and see text for the sub-vertical reverse faults.

corresponds to the Goiás block of Archean-Paleoproterozoic continental crust rocks, part of the westernmost margin of the São Francisco paleocontinent since the Paleoproterozoic (Cordeiro et al., 2014). The External Zone comprises the crystalline basement plus sub-greenschist facies rocks of passive margin-like siliciclastic-carbonate sequences (also covering the western part of the São Francisco craton and parts of the Internal Zone), napes of back-arc basin rocks, and a Neoproterozoic carbonate- siliciclastic sequence that records contribution from sources in the crystalline basement and, on top, from the Goiás Magmatic Arc as well.

The Araguaia belt is divided in two longitudinal domains. Summarizing from Paixão et al., 2008): the easternmost domain comprises supracrustal rocks of the Estrondo Group, which includes quartzite, muscovite-, kyanite- and magnetite-bearing quartzite and oligomictic metaconglomerate (Morro do Campo Formation) followed upwards 


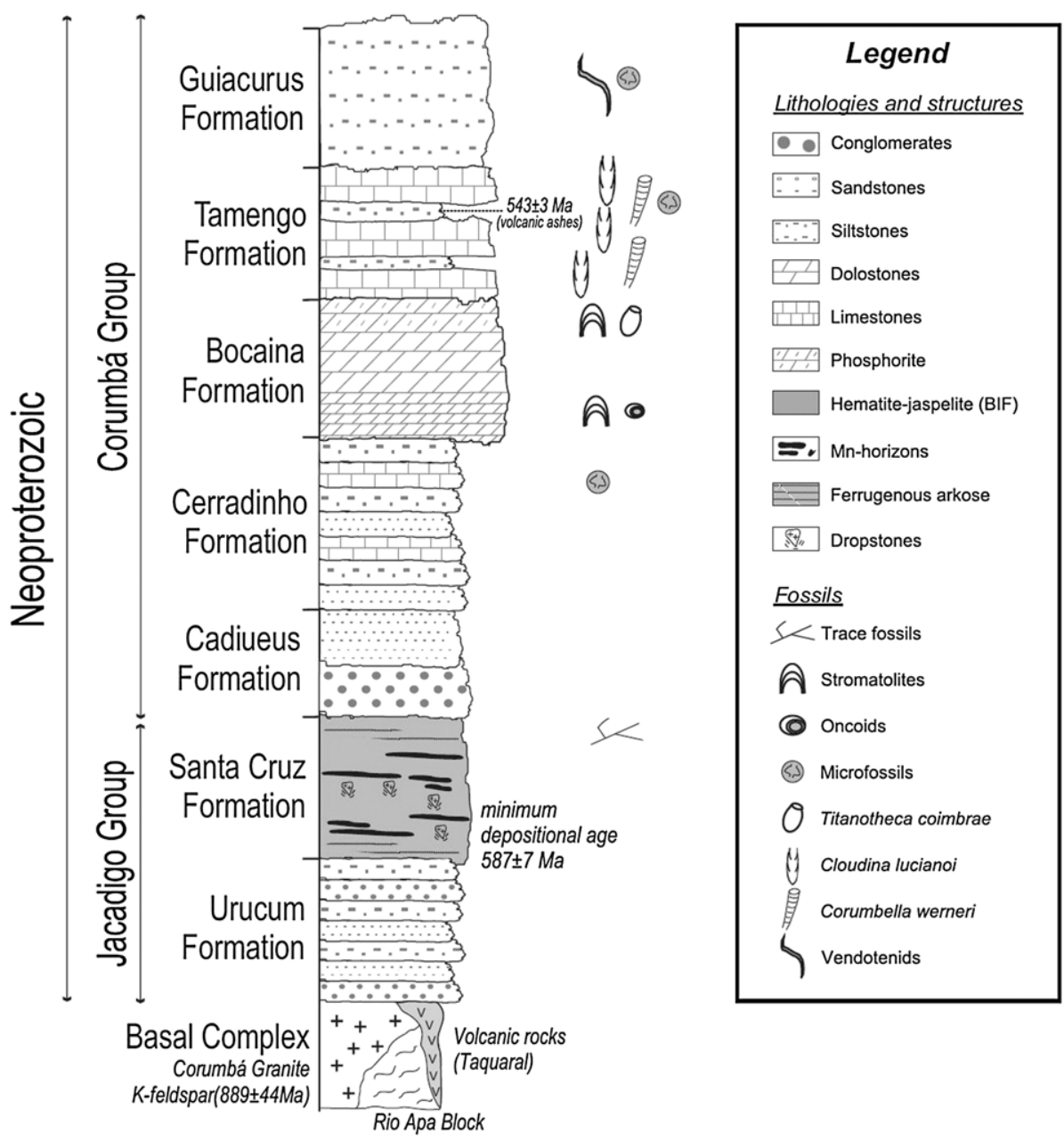

Fig. 3. Basic Lithostratigraphy column of the Jacadigo and Corumbá groups in the Corumbá area (based on Walde et al., 2015 and Piacentini et al., 2013).

by muscovite-biotite schist and calc-schist, marble, staurolite, kyanite, or fibrolite schist (Xambioá Formation) and feldspathic schist with quartzite, biotite schist and calc-schist intercalations (Canto da Vazante Formation), Archean-Paleoproterozoic granulites and gneisses of the crystalline basement that corresponds to the core of structural domes and a tectonic slice adjacent to the Goiás Magmatic Arc, and Neoproterozoic granitoids; the westernmost domain consists of the Tocantins Group (plus the crystalline basement) which includes slate, meta-siltstone, meta-arkose, meta-greywacke, meta-limestone, banded iron formation, quartzite, and slices of mafic-ultramafic ophiolitic rocks (Couto Magalhães Formation), and chlorite schist, quartz-chlorite schist, sericite-chlorite schist and metabasite (Pequizeiro Formation). The metamorphism reached sub-greenschist facies in Tocantins Group rocks and upper amphibolites facies in Estrondo Group rocks, in which occur S-type granites as old as $655 \mathrm{Ma}$ (Alvarenga et al., 2000).

As quoted in Paixão et al. (2008), U-Pb ages of detrital zircons indicate that the siliciclastic rocks of the Morro do Campo Formation (Estrondo Group) derive from Archaean (2909 + 5 to $2668+2 \mathrm{Ma}$ ) and Paleo-Mesoproterozoic sources (1748 $\pm 5 \mathrm{Ma}$ ) although some rocks of the Xambioá Formation display Sm-Nd model ages suggesting the contribution of Neoproterozoic rocks (Brasiliano sources in their own words). Moreover, U-Pb ages of detrital zircons from the Tocantins Group rocks indicate: (1) - meta-rhythmite and meta-greywacke derived from both Neoproterozoic and Paleoproterozoic sources; and (2) - a minimal age of $544 \mathrm{Ma}$ for deposition of carbonate and banded iron formation rocks (Couto Magalhães Fm) on the passive continental margin. This formation tectonically underlies slices of the Quatipuru ophiolite and is the equivalent of the Araras-Corumbá platform in the Paraguay belt.

According to Alvarenga and Trompette (1993) and Alvarenga et al. $(2000,2007,2011)$ the lithostratigraphy record in the Paraguay belt fits in an eastward-deepening basin and allow definition of three longitudinal structural domains parallel to the Amazon craton border. The westernmost platformal glaciomarine environment comprises the basal Puga Formation (diamictite; Marinoan glaciation) which unconformably overlain the crystalline basement and is sharply overlain by the Araras Group (pink dolostone, limestone and mudstone, and dolostone plus sandy dolostone, respectively corresponding to the Mirasol D'Oeste, Guia, and Nobres formations.). The Puga diamictite passes gradually eastwards into the Cuiabá Group (diamictite, quartzite, and phyllite) so that the Puga-Cuiabá lithotypes record a continental slope depositional enviroment and, further east, record a glacial diamictite-turbidite sedimentation in the outer slope (basinal) environment. A similar craton-basin record is also noticed in the Bonito area (Bodoquena Range; Fig. 1b).

The Araras carbonate covered the Puga and Puga-Cuiabá diamictites all across the basin. In the Corumbá area and in the Tucavaca aulacogen, the basal (Puga-equivalent) diamictites are respectively in the Jacadigo and Boqui Groups (Trompette et al., 1998). In the aulacogen and in the southernmost Paraguay belt (from Corumbá to Bonito) the Araras lithotypes constitute the Corumbá Group (Trompette et al., 1998), so that the Araras-Corumbá carbonate platform follows all along the eastern part of the Amazon craton and Rio Apa block (Fig. 1b). 

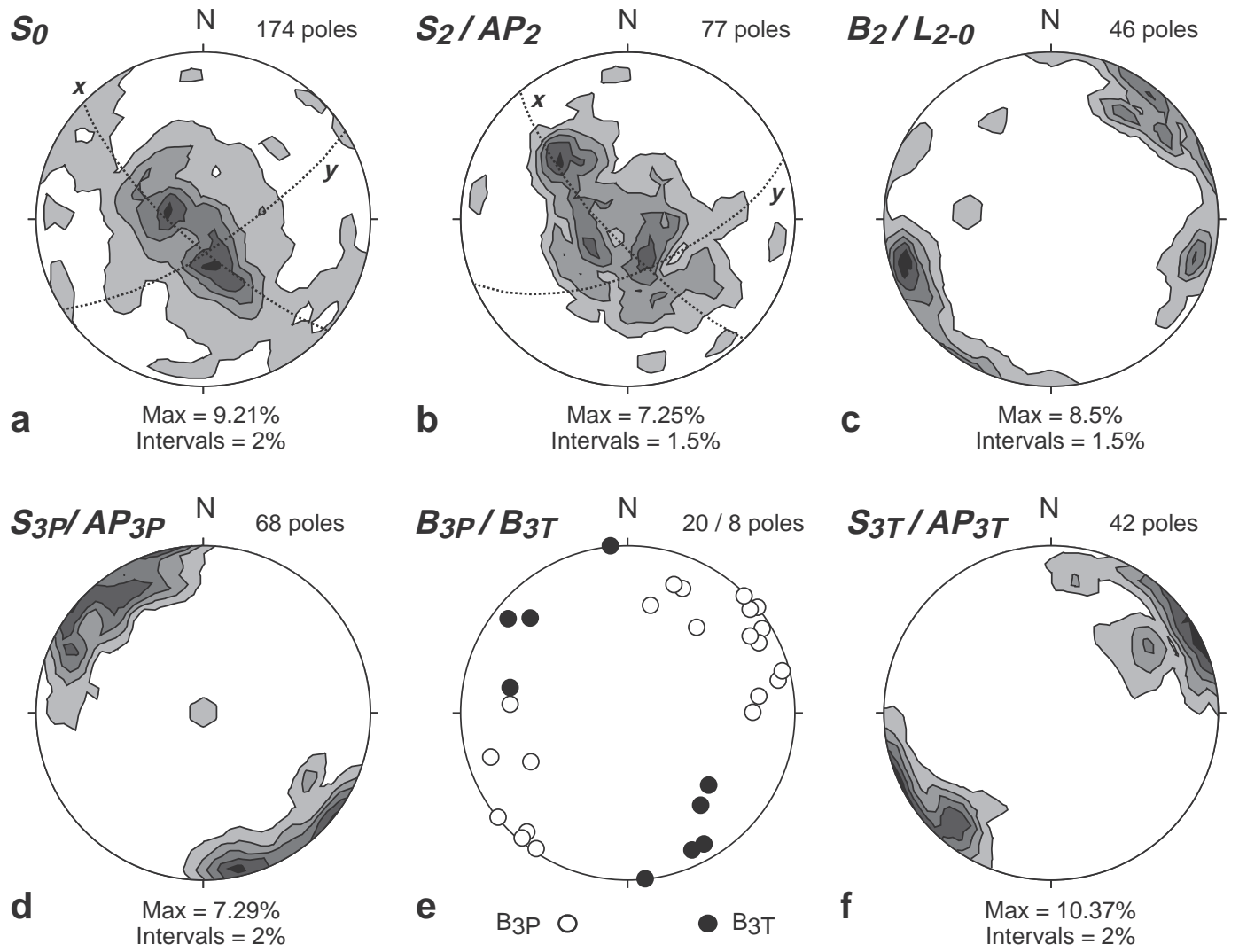

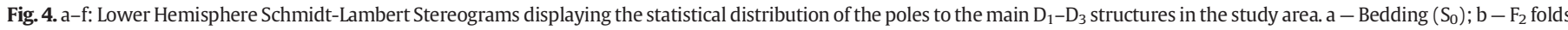

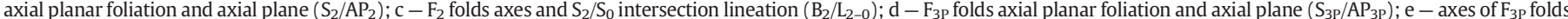

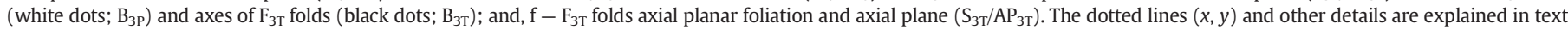
(Sections 3.1-3.7, and 4.1).

West and North of Cuiabá the Araras platform is covered by the Serra Azul Formation (diamictite and mud-siltstone; Gaskyers glaciation; Alvarenga et al., 2007) which is the basal in the Alto Paraguay Group (Figueiredo et al., 2008) and passes upwards into the Raizama Formation (sandstone, mudstone, silicious carbonate), the Sepotuba Formation (mudstone, shale, sandstone) and the Diamantino Formation (sandstone and mudstone). The Alto Paraguay Group has equivalent only in the aulacogen (the Murciélago Group; Trompette et al., 1998), not elsewhere in the Paraguay belt.
From the vicinities of Cuiabá, the Cuiabá Group rocks extend continuously until Bonito and Nova Xavantina, respectively in the southernmost and easternmost parts of the Paraguay belt (Fig. 1a-b). Around Nova Xavantina, the Cuiabá Group is a sedimentary-volcanic sequence of fine siliciclastics, banded iron formation, tuffs and basic volcanic rocks (Dantas and Martinelli, 2003). Basic volcanics are also described in the Bonito area and are interpreted to exist, although very weathered, in the surroundings of Cuiabá (Luz et al., 1980; and references therein).
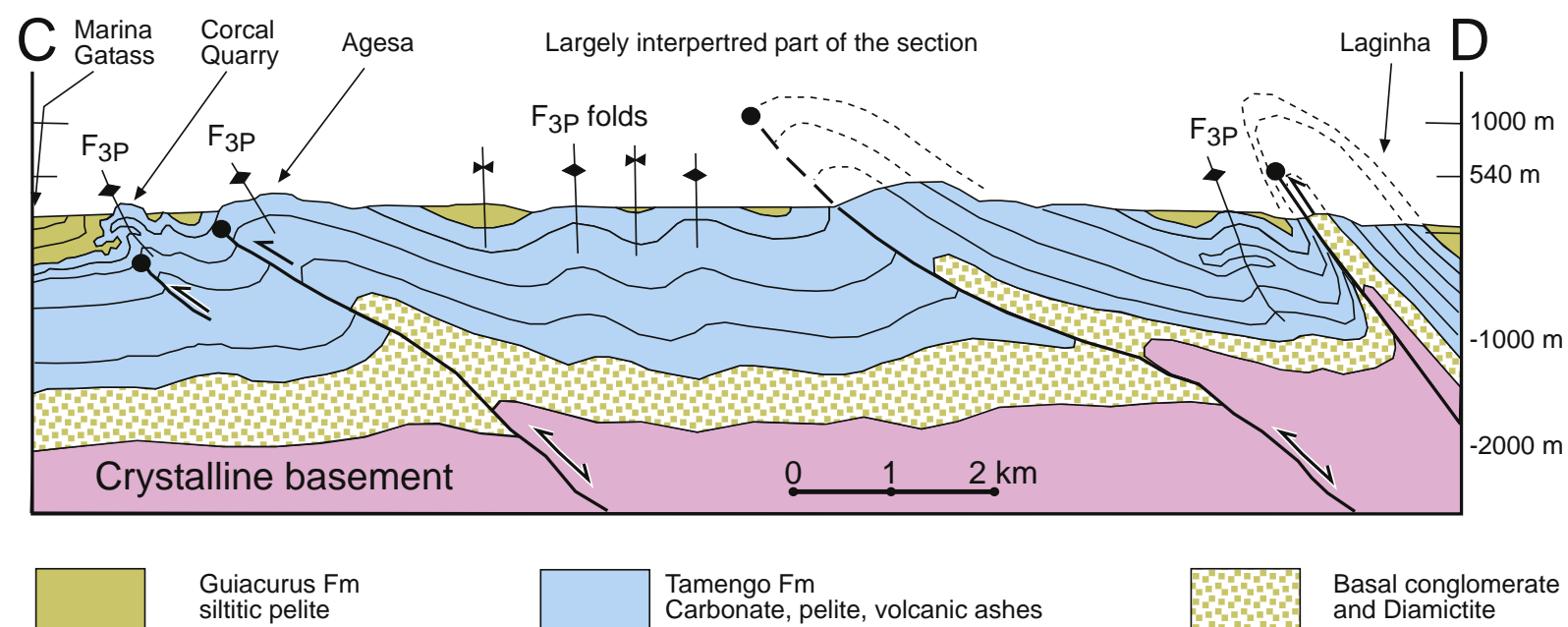
Gravity modeling supports the A-subduction of the Amazon paleocontinent under the Parnaíba continental lithosphere and the western San Franciscan paleo-margin during the build-up of the Araguaia belt and the northern segment of the Brasília belt (Fig. 1a; Ussami and Molina, 1999). The Amazon-São Francisco collision took place in the 650/640-590/580 Ma interval as a consequence of the consumption of the Goiás Ocean (900-640 Ma; Pimentel et al., 2000; Fuck et al., 1994, 2006). The Paraná block participated in the second half of the construction of the Tocantins Province and also played a critical role in the evolution of the Paraguay belt. The geophysical boundary between this block and the Amazon craton is situated under the Paraná basin and is likely (Curto et al., 2015) a segment of the NE-SW Transbrasiliano-
Kandi shear zone (Cordani et al., 2013) which, in South America (Fig. 1a), stretches all across Brazil, Paraguay, and part of Argentina.

Earlier, 635-590/580 Ma ago, and still related to the consumption of the Goiás Ocean, the eastern margin of the Paraná block A-subducted under the southwestern margin of the São Francisco paleo-continent, consequently imprinting late crustal SW-NE shortening $\left(D_{3}\right)$ throughout the southern segment of the Brasília belt (D'el-Rey Silva et al., 2004, 2008, 2011; D'el-Rey Silva, 2008). Later, during the 540-518/ 513 Ma interval (McGee et al., 2012; Piacentini et al., 2013) and after consumption of the ocean precursor of the Paraguay belt, the western margin of the Paraná block collided with the eastern margin of the Amazon-Rio Apa paleo-continent, forming the Paraguay belt. According to
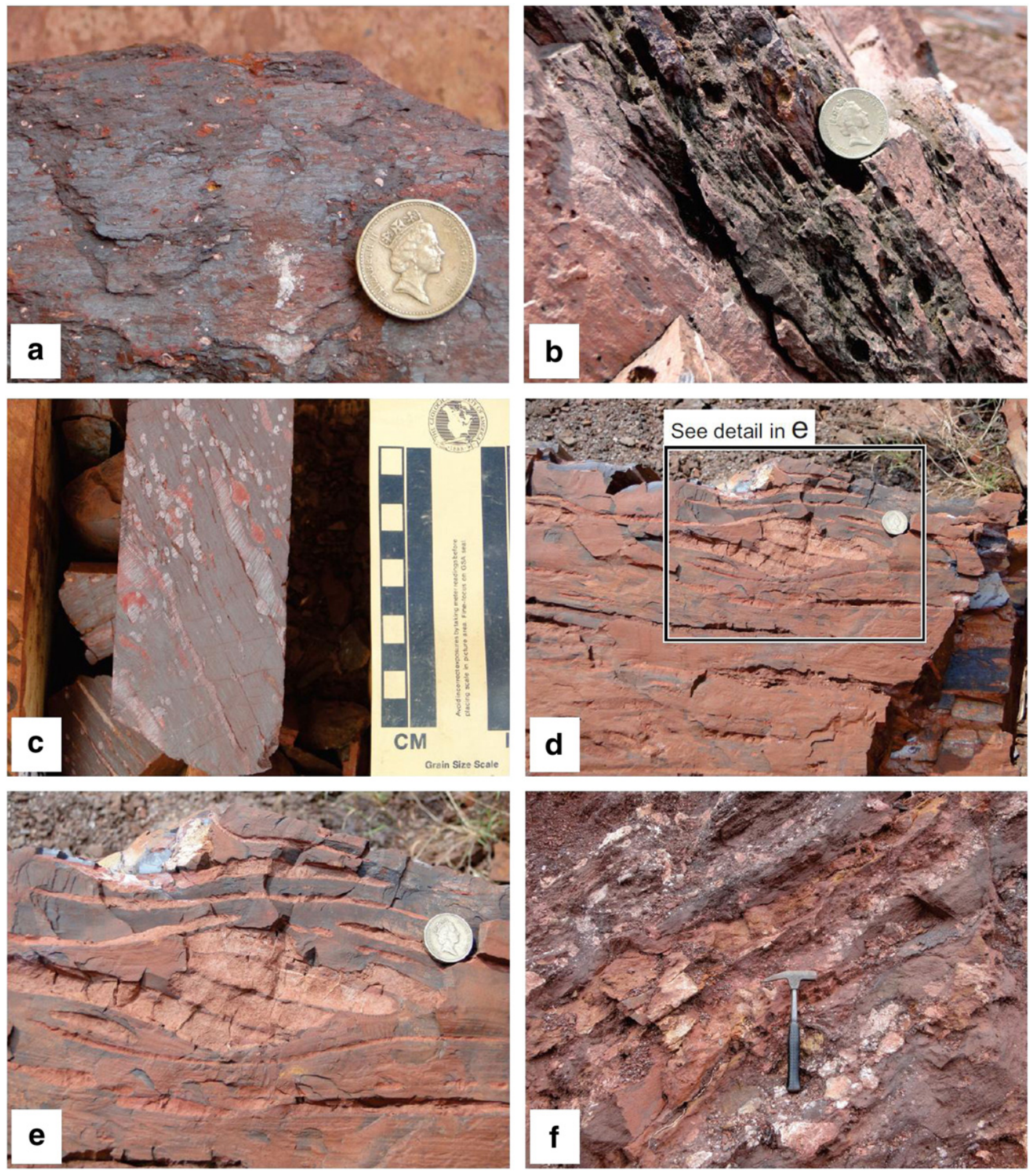

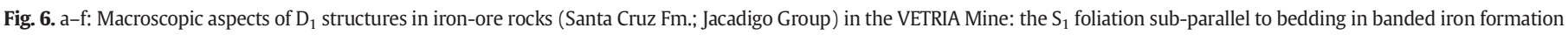

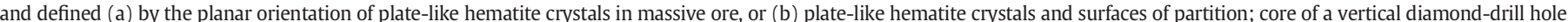

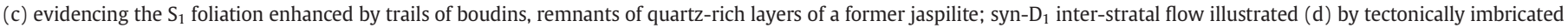

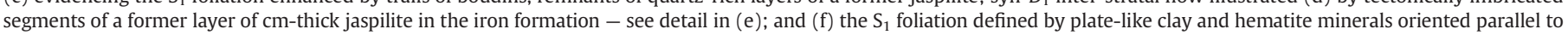
dm-thick layers of sandstone in a lens of ferriferous diamictite. 

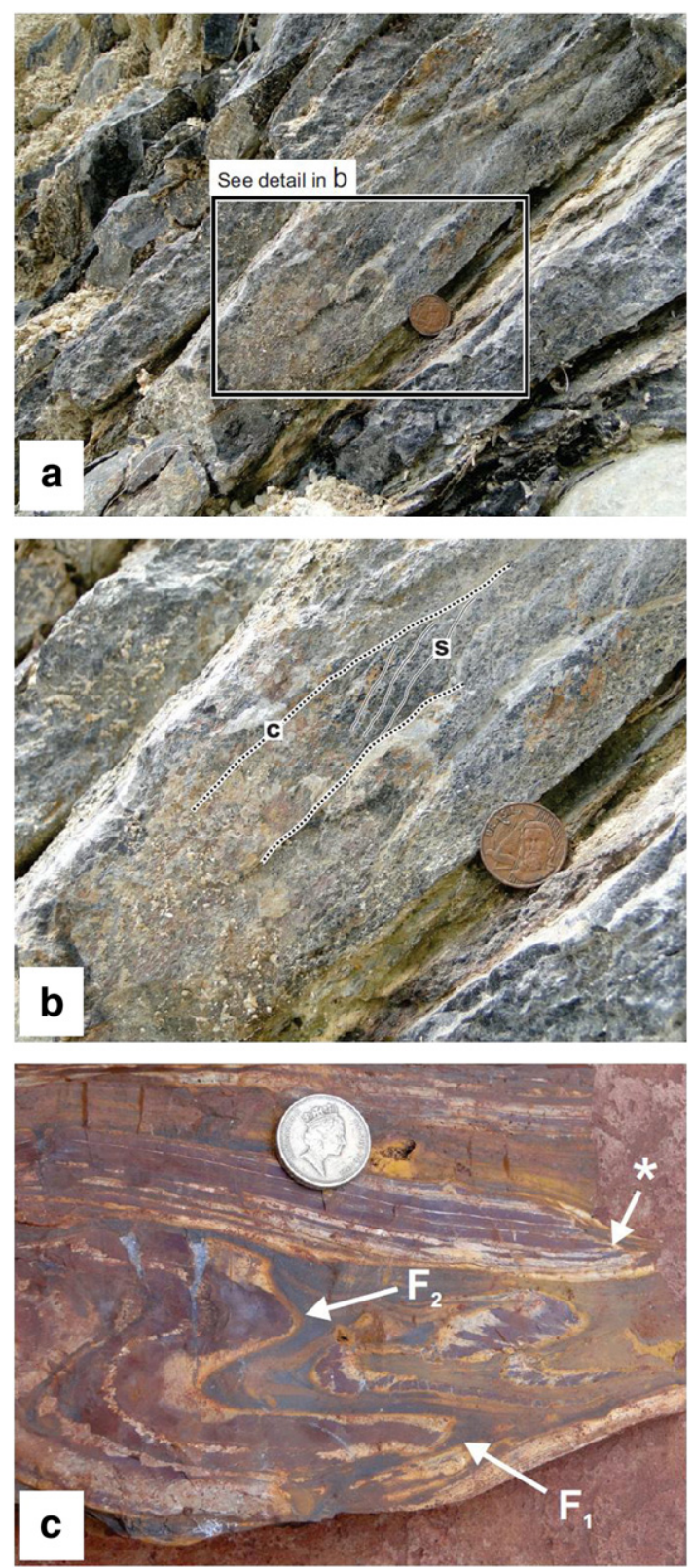

Fig. 7. a-c: Further evidence of $D_{1}$ deformation. (a) The $S_{1}$ foliation in impure carbonate rocks (Tamengo Fm., Corumbá Group) exposed in the Corcal Quarry. The details in (b) displays the locally sheared carbonate layers where the $S_{1}$ foliation is defined by plate-like clay minerals along S-like surfaces of an $\mathrm{S}-\mathrm{C}$ pair, contained and limited within $C$ surfaces coincident with the bedding $\left(C=S_{0}\right)$. (c) $-F_{1}$ intrafolial fold coaxially re-folded by highly asymmetric $\mathrm{F}_{2}$ folds in iron-formation rocks (VETRIA Mine). The starred arrow points to another candidate of $F_{1}$ fold.

Godoy et al. (2010) the collision Paraná-Amazon-Rio Apa is in part evidenced by seven granitic intrusions (Fig. 1a-b) which indicate continental arc magmatism in the evolution of the Paraguay belt.

\section{2. - Summary lithostratigraphy record (Corumbá Area)}

According to recent summaries (Piacentini et al., 2013; Walde et al., 2015) the Neoproterozoic-Cambrian rocks in the Corumbá area (Fig. 3) may be divided in the Jacadigo and Corumbá Groups. These rocks are unconformably overlain by Quaternary sediments of the Pantanal Formation.

The Jacadigo Group comprises basal diamictite, volcanogenic material and arkose beds (Urucum Fm) and passes upwards into banded hematite-rich jaspilite with manganese ore intercalations and lens of
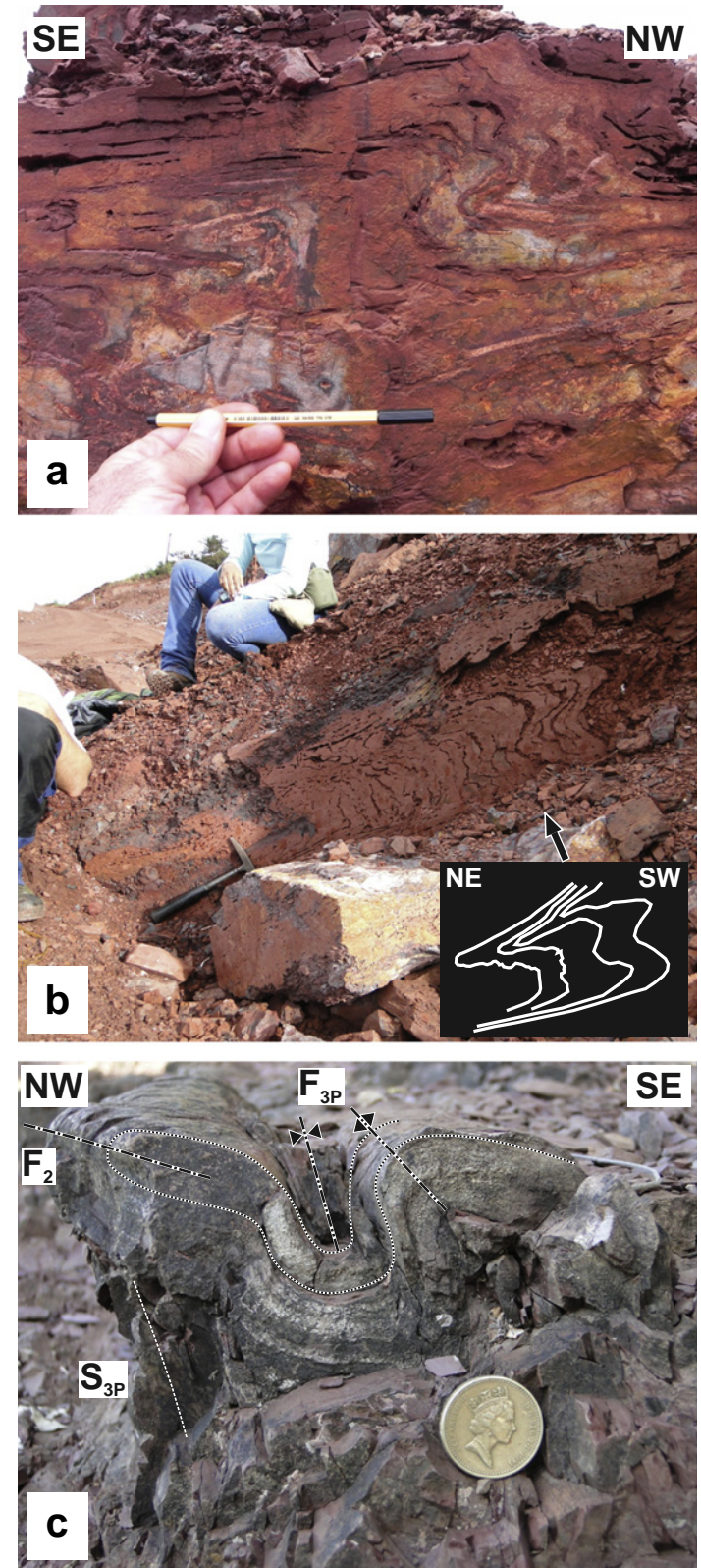

Fig. 8. a-c: Field examples of the $F_{2}$ folds. The photographs (a) and (b) evidence layers $\left(\mathrm{S}_{0} / \mathrm{S}_{1}\right)$ of iron-formation rocks (VETRIA Mine) deformed by asymmetric $\mathrm{F}_{2}$ folds. The $\mathrm{F}_{2}$ fold in (b) verges down-to-NE because the layers are part of the north-eastern limb of a hectometer-scale $\mathrm{F}_{3 \mathrm{~T}}$ antiform. (c) - Layers of Tamengo siltite (Marina Gatass outcrop) affected by $\mathrm{F}_{2}$ folds co-axially refolded by strongly-inclined by $\mathrm{F}_{3 \mathrm{P}}$ folds associated with a strong $S_{3 P}$ axial planar foliation.

diamictite (Santa Cruz Fm) containing boulders of ice-rafted dropstones (Trompette et al., 1998). The Corumbá Group comprises five formations in the Bodoquena Range area, but only three of these occur in the Corumbá area (Fig. 3): the Bocaina Formation (conglomerate, rudstone, and sandstone capped by dolomite and dolostone), the Tamengo Formation (limestone with intercalations of marl, siltite, and volcanic ash) and, discordantly deposited on top (Walde et al., 2015), the Guiacurus Formation (gray siltite and finer-grained pelite). Here-inafter we refer to the Corumbá Group as it is in the Corumbá (study) area.

Even though the Corumbá Group rocks cover the Jacadigo rocks conformably (evidence in the São Carlos Farm outcrop; Fig.2) basal conglomerate of both groups directly overlies the crystalline basement in the Corumbá area. These facts (Walde, 1988) support interpreting the basal conglomeratic rocks and the Fe-Mn mineralized layers of the Jacadigo Group and equivalents in the Tucavaca belt as the record of 

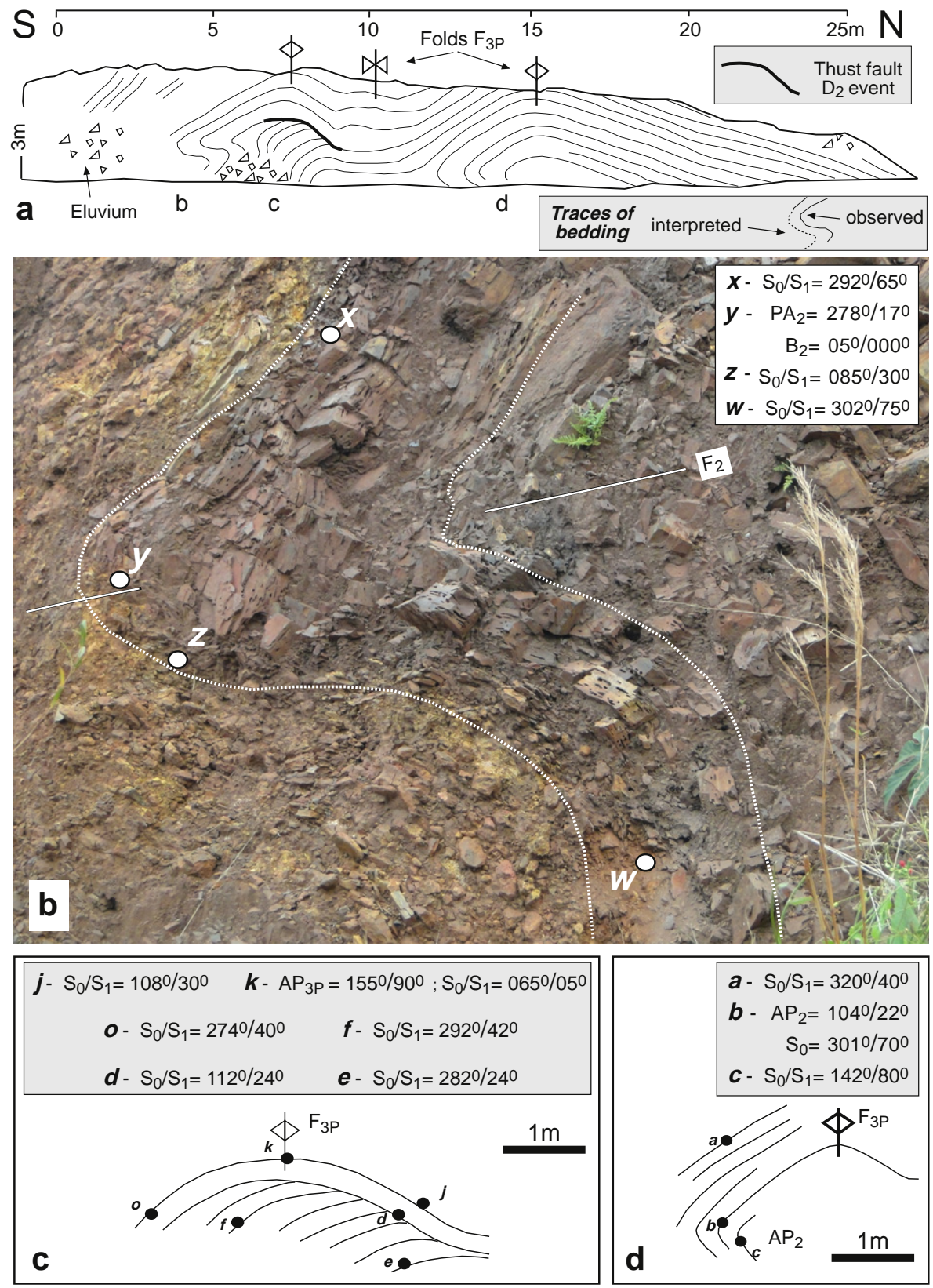

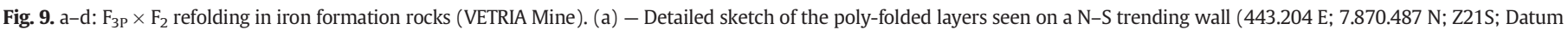

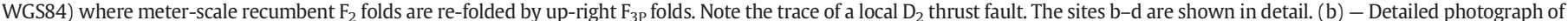
the $\mathrm{F}_{2}$ hinge with indication of measured attitudes (inset). (c-d) - Line-drawings and attitudes of planar and linear structures in the respective sites indicated in (a).

the rift stage during basin opening, whereas the Corumbá Group rocks are the record of syn- to post-rift sedimentation (Trompette et al., 1998).

\subsection{Ages of sedimentation and deformation and Provenance data}

According to Jones (1985) and Walde (1988) the sedimentation of the Jacadigo and Corumbá rocks lasted across the NeoproterozoicCambrian border and the deformation/metamorphism lasted until $500 \mathrm{Ma}$ that is the Rb-Sr age for the well-known São Vicente posttectonic granitic intrusion of the Cuiabá area. A rich Ediacarian fauna has been described across the Paraguay belt (see a summary in Fig. 3 ) and Alvarenga et al. $(2004,2007)$ respectively established the age of $\sim 635 \mathrm{Ma}$ for Marinoan basal diamictite of the Puga Formation, and
580 Ma for upper diamictite (Gaskyers glaciations) of the Serra Azul Formation (bottom of the Alto Paraguay Group).

According to Piacentini et al. (2013), ${ }^{40} \mathrm{Ar} /{ }^{39} \mathrm{Ar}$ isotopes data from late-diagenetic to early-metamorphism cryptomelane in Mn-bearing layers (Urucum Formation) and from braunite and muscovite in Jacadigo Group diamictite respectively indicate a minimal depositional age of $587 \pm 7 \mathrm{M}$ for the upper part of Jacadigo Group and the $\sim 547 \pm 3$ to $513 \pm 4$ Ma interval for deformation/metamorphism and final cooling of these rocks.

Furthermore, zircons from volcanic ashes of the Tamengo Formation (Fig. 3) provided the $543 \pm 3 \mathrm{Ma} \mathrm{U}-\mathrm{Pb}$ age of sedimentation of the upper part of the Corumbá Group (Babinski et al., 2008; Boggiani et al., 2010). The two last U-Pb ages of sedimentation mentioned justify interpreting the diamictites in the Jacadigo and Corumbá groups as respectively correlated to the Marinoan and Gaskyers glaciations, 

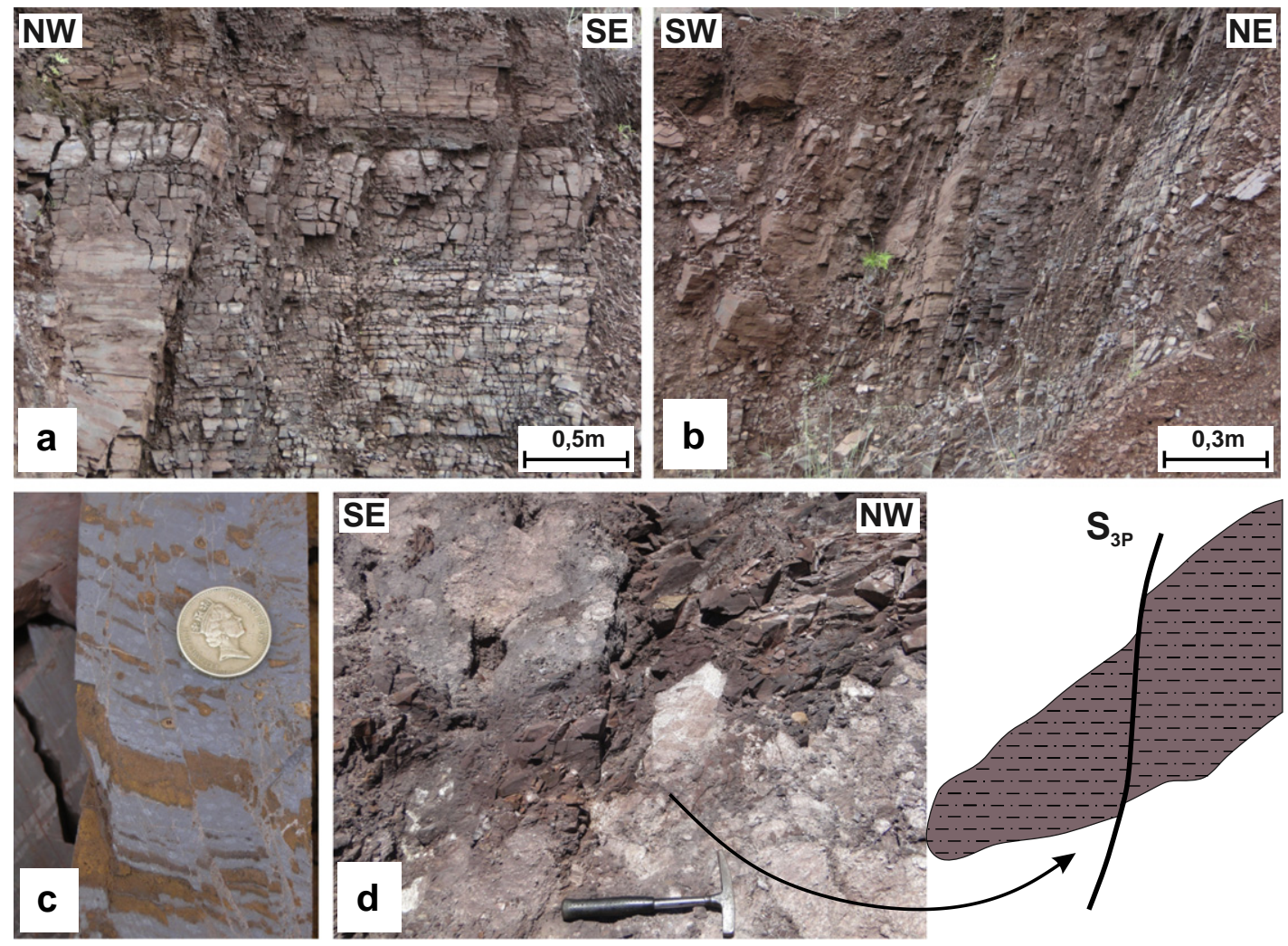

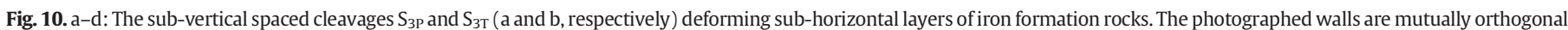

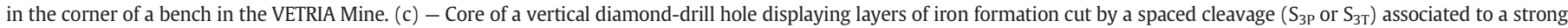

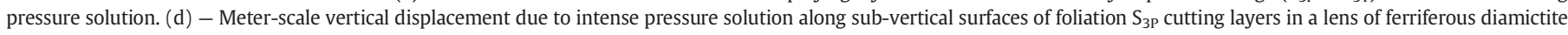
(see inset on the right).

similarly as reported for diamictites in the Cuiabá area (see in the previous paragraph).

$\mathrm{U}-\mathrm{Pb}$ ages recently obtained in detrital zircons from Puga diamictites in the Cuiabá and Bodoquena areas indicate that the Puga siliciclastics largely derived from rock constituents of the Amazon-Rio Apa paleo-continent, but the youngest zircon population in Puga diamictite collected in the Bodoquena Range (706 $\pm 9 \mathrm{Ma}$ ) may have derived from Neoproterozoic rocks either from the Goiás Magmatic Arc or from Laurentian external fold belts West of the sampled area in Neoproterozoic paleogeography reconstructions (Babinski et al., 2013).

The data above point to the sedimentary/volcanic infilling between $635 \mathrm{Ma}$ and $540 \mathrm{Ma}$ in the Paraguay basin, but the start-up may have been since around $700 \mathrm{Ma}$, particularly in the Bonito area. They also define the interval 548/540-518/513 Ma for deformationand-metamorphism, whereas the orogenesis sealed $\sim 518 \pm 4$ Ma ago (U-Pb zircon age in the post-tectonic São Vicente granite; McGee et al., 2012) and final cooling was $\sim 513 \pm 4$ Ma ago, at least for Jacadigo Group rocks nearby Corumbá $\left({ }^{39} \mathrm{Ar} /{ }^{40} \mathrm{Ar}\right.$ data; Piacentini et al., 2013; as above).

Additionally, Dantas et al. (2009) showed that the rocks of the upper Alto Paraguay Group display 1.68-1.50 Ga Nd T $\mathrm{DM}_{\mathrm{DM}}$ model ages suggesting derivation from Neoproterozoic (or younger?) juvenile source rocks, whereas the vast majority of rocks of the Cuiabá Group (Cuiabá area) displays model ages ranging 2.22-1.57 Ga indicative of crystalline basement source rocks.

Bandeira et al. (2012) reported the occurrence of $541 \pm 7$ Ma old detrital zircons (U-Pb data) in the uppermost siliciclastics (Diamantino Formation) of the Alto Paraguay Group, characterized these as deltaic lobes infilling an internal lake (the Paleozoic foreland basin also in Dantas et al., 2009) that succeeded the last definitely marine deposits (Sepotuba Formation) in the Paraguay basin.

\subsection{Map-and section-pattern of the Jacadigo-Corumbá rocks}

In geological maps, the Jacadigo Group rocks occur along a curved belt of discontinuous hills (named as in Fig. 2) between belts of Corumbá Group rocks, the northern one around the city of Corumbá and the other spreading westwards of the city of Albuquerque. The top of these hills consists of layers of Mn-Fe bearing rocks subhorizontal or gently-dipping to SE, and stays as high as $\sim 1000 \mathrm{~m}$ above sea level, whereas the Corumbá Group rocks occur much below, $\sim 350 \mathrm{~m}$, locally reaching $540 \mathrm{~m}$ (Google Earth topographic profile, 2014). Their bottom consist of basal diamictite and the crystalline basement (generally strongly weathered; Walde, 1988). As seen from different places along the two roads leading to the city of Corumbá, all these rocks are transected vertically by deep valleys that, in maps, are parallel to SW-NE straight lineaments and, in geological sections (e.g. section $A B$, Fig. 2) are coincident with sub-vertical surfaces interpreted as normal faults (e.g. Godoi et al., 2001; Trompette et al., 1998).

However, since when Dorr (1944) characterized the narrow valley between the hills named Morro Urucum and Morro Santa Cruz as coincident with the trace of a NW-verging contractional fault cutting hinges of large-scale recumbent folds which he interpreted as drag folds, no additional geological information was published so far about such faults and folds. Ahead we provide further information and discuss in detail the role of the sub-vertical faults in the geology of the area.

\section{Structures and structural evolution}

\subsection{Introduction}

The rocks (Jacadigo and Corumbá groups) in the Corumbá area underwent ductile and brittle deformations represented by folds, 

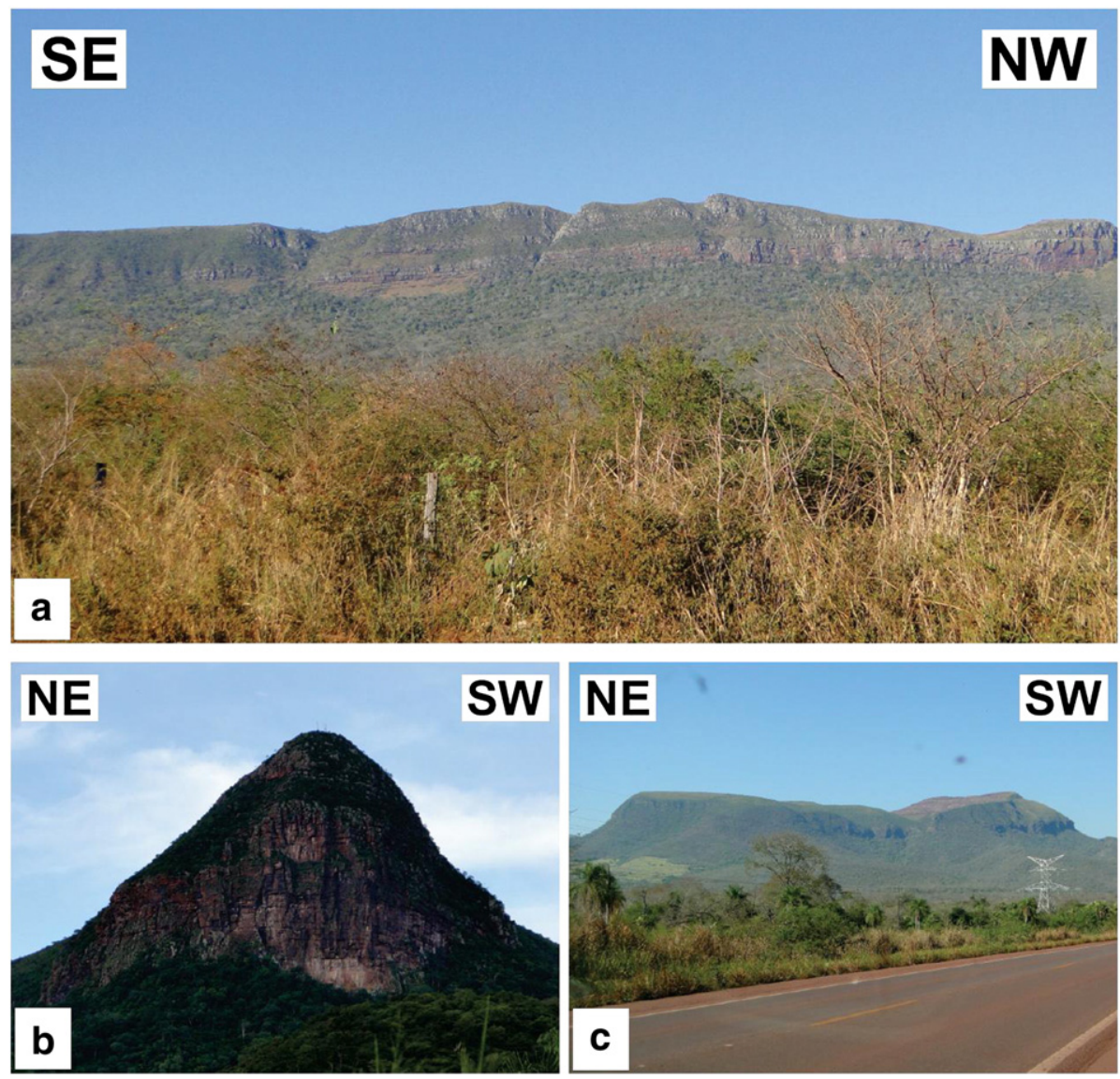

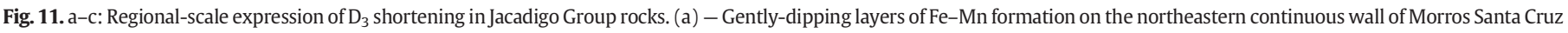

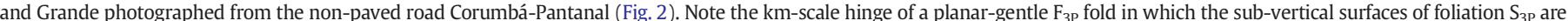

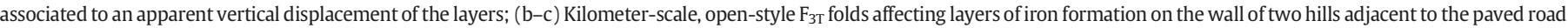

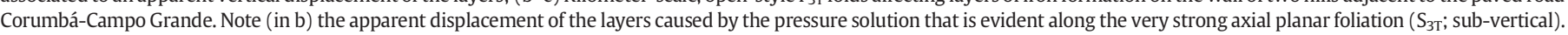

foliations, faults, and fractures which record three main phases $\left(D_{1}-\right.$ $D_{2}-D_{3}$ ) of a progressive and monocyclic event under very low metamorphism.

In essence, $D_{1}$ consisted of interestratal flow; $D_{2}$ records ductile flow characterized by asymmetric folding and thrusting indicating top-tothe-NW (reverse-sense) kinematics; and $\mathrm{D}_{3}$ corresponds to crustal shortenings superimposed upon a stack of $\mathrm{D}_{1}-\mathrm{D}_{2}$ tectonites and acting coevally in two nearly orthogonal directions. The shortening in the SE-NW direction (the same for $\mathrm{D}_{1}-\mathrm{D}_{2}$ ductile flows) is labeled $\mathrm{D}_{3 \mathrm{P}}$, whereas the shortening in the SW-NE direction is labeled $\mathrm{D}_{3 \mathrm{~T}}$. The labels $P$ and $T$ are respectively because (see discussion; Section 4.2 ) deformation $\mathrm{D}_{3 \mathrm{P}}$ is most likely associated to the final closure of the basin precursor of the Paraguay belt and deformation $\mathrm{D}_{3 \mathrm{~T}}$ may be related to the inversion of the rift precursor of the Tucavaca belt.

The tectonic structures affected the sedimentary layering (bedding; $\mathrm{S}_{0}$ ) that is commonly marked by intercalation of mm-to dm-thick layers of different compositions and/or colors, such as in (meta)pelite, (meta)rhythmite, banded iron formation, Corumbá Group carbonate, and dolomite layers as thick as $1 \mathrm{~m}$ (Bocaina Formation; Corumbá Group). Although the definition of bedding is normally impossible in bodies of diamictite (basal Santa Cruz Fm; Jacadigo Group) it may be done where these eventually include intercalated layers of sandstone and/or siltstone.

Stereograms (Fig. 4a-f) were elaborated with the aid of the software Stereonet, treating altogether about 450 attitudes of bedding planes and $\mathrm{D}_{1}-\mathrm{D}_{3}$ tectonic structures collected (dip-direction method; also used herein) during field work.

As a consequence of the structural/tectonic evolution, the layers commonly dip gently-moderately, mostly to SE or NW, and their geometry is controlled by broad, gentle to open-style, hm-km scale $F_{3 P}$ folds and hm-scale asymmetric $F_{2}$ folds, with minor contribution of faults. These can be divided in a group of typical thrust faults and another group associated to sub-vertical surfaces, the different meanings of which are discussed in detail (Section 3.7). The geological section CD (Fig. 5; see location in Fig. 2) incorporates the new structural data here-in-after described in detail for the Corumbá Group rocks.

\subsection{Tectonic phase $D_{1}$}

$D_{1}$ structures are the $S_{1}$ foliation, mainly, and (rare) $F_{1}$ folds. They are abundant in the Jacadigo Group rocks and very scarce in Corumbá Group rocks, but always indicating the operation of inter-strata flow well in the beginning of the tectonic deformation in the area.

In layers of banded iron formation (Santa Cruz Fm) which commonly display evidence of intense intra-stratal, layer-parallel ductile flow, the $S_{1}$ foliation is quite penetrative and consists of a fine mineral foliation defined by very fine plates of hematite (Fig. 6a-b). The intrastratal flow was also the main mechanism responsible for the high concentration of hematite in the iron ore, once it provided the bedding-perpendicular compression for removal of the silica, as evidence the pervasive transformation of $1 \mathrm{~mm}-1 \mathrm{~cm}$ thick silica-rich layers (originally continuous layers of chert) into disrupted layers defined by trails of elliptical-shaped boudins (not rarely asymmetric) intercalated to dark gray, $1 \mathrm{~mm}-1 \mathrm{~cm}$ thick iron-rich layers (Fig. 6c). Other evidences of inter-strata flow is the imbrication of former layers of jaspilite intercalated with the iron-rich layers (Fig. 6d-e) and rotated boudins associated with asymmetric tails of hematite (not shown). 

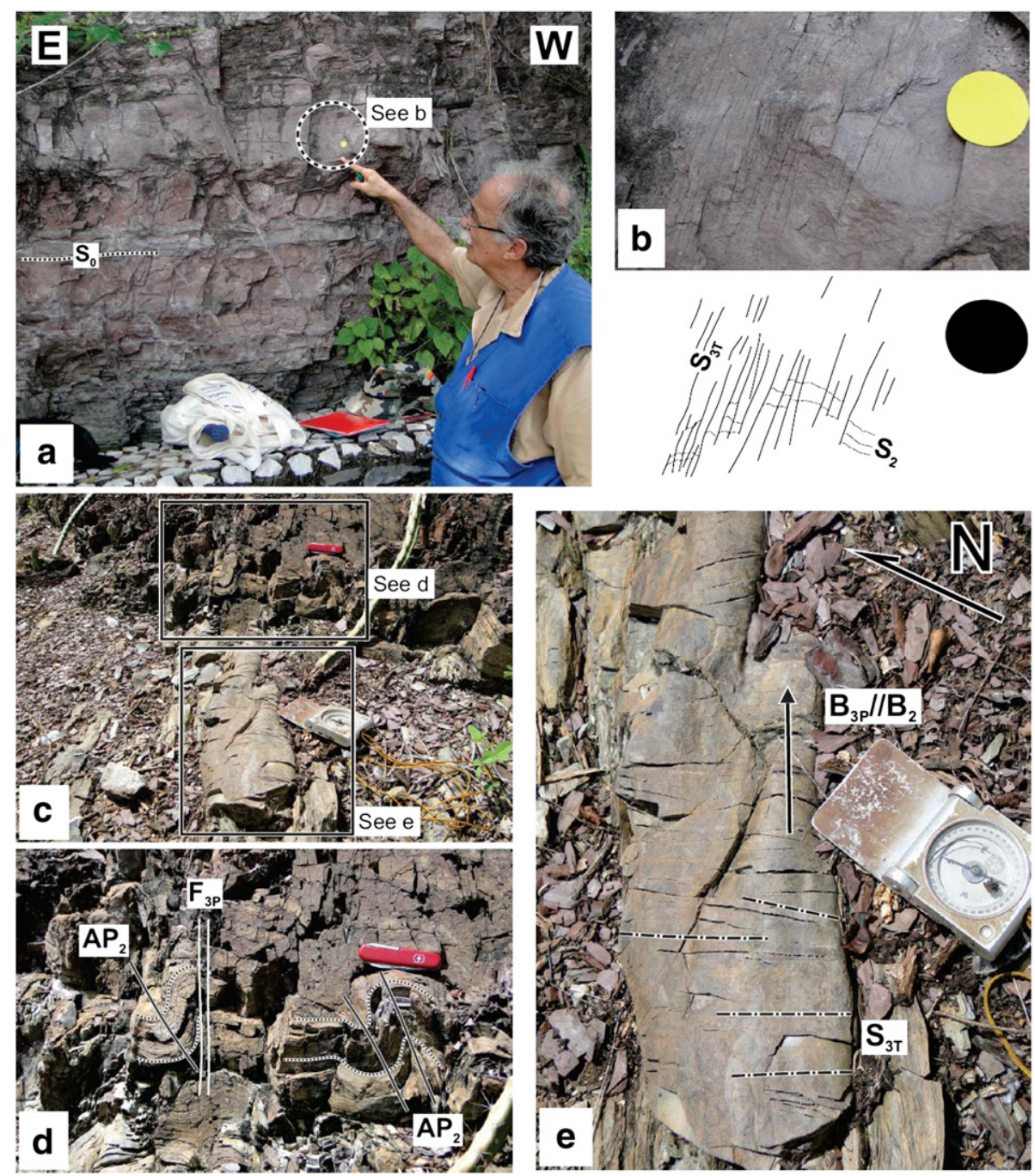

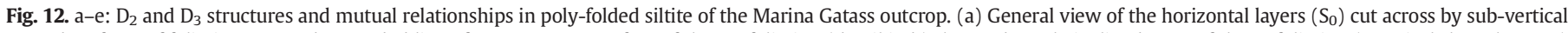

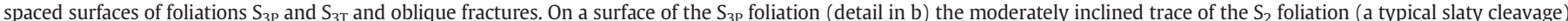

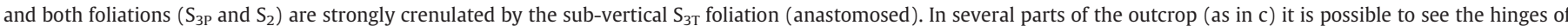

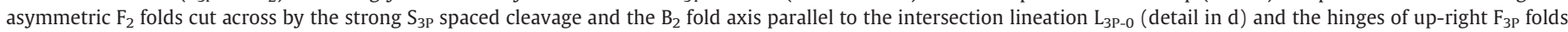
transversally cut by the $S_{3 \mathrm{~T}}$ foliation, and the trace of this foliation shortened by $F_{3 \mathrm{P}}$ folds (on the floor of the outcrop; e).

In siltic-arenitic layers found within basal diamictites (Jacadigo Group; VETRIA Mine) $S_{1}$ is commonly expressed by the preferential orientation of very small platy-like minerals, probably illite or very fine grains of white mica (Fig. 6f). The metamorphic white mica dated by Piacentini et al. (2013) is another example of $S_{1}$ foliation in such diamictites, considering that, according to our detailed study, $\mathrm{D}_{2}$ and $\mathrm{D}_{3}$ deformations did not develop mica mineral foliations in the area. These data point to low-greenschist facies metamorphism basal rocks of the Jacadigo Group.

In Corumbá Group rocks, the surfaces of $S_{1}$ foliation are defined by the planar preferential orientation of very fine plate-like clay minerals (ilite, most probably) and rest at very low angle with bedding and contained within layers of siliciclastic rocks and impure carbonate (Tamengo Formation) and not crossing these (Fig. 7a-b). As such, the $\mathrm{S}_{1}$ surfaces compare to the $\mathrm{S}$ components of typical S-C pairs in which the $\mathrm{C}$ components are the bedding surfaces, further indicating intrastratal flow during phase $\mathrm{D}_{1}$.

The few specimen of $F_{1}$ folds observed so far consist of dm-scale intrafolial folds deforming layers of banded iron formation and refolded co-axially by $F_{2}$ folds (Fig. 7c). The fact that the strong anisotropy $S_{0} / S_{1}$ clearly turns around the hinge of $F_{2}$ folds justifies interpreting the $D_{1}$ intra-stratal flow and the intra-folial folds (follow the star in Fig. 7c) as one phase of deformation independent of the $\mathrm{D}_{2}$ phase. However, because the $F_{1}$ specimen were found in boulders resultant from mining blasting (VETRIA Mine) we have not a population of attitudes of $F_{1}$ fold axis available for statistical analysis. Even so, the fact that the foliation $S_{1}$ is basically parallel to the layers implies the same statistic distribution of bedding data $\left(\mathrm{S}_{0}\right.$; Fig. $\left.4 \mathrm{a}\right)$.

\section{3. - Tectonic phase $D_{2}$}

This phase resulted in ductile regional flow in the SE-NW direction and originated $F_{2}$ folds $\left(F_{2}\right)$, their axial planar foliation $\left(S_{2}\right)$, and also thrust faults. These structures deform the bedding and $\mathrm{D}_{1}$ structures and imply a top to NW reverse-sense kinematics.

Extremely common in Jacadigo-Corumbá rocks across the study area, the $\mathrm{F}_{2}$ folds are (e.g. Figs. 8a-c) highly asymmetric, tightisoclinals, moderately to gently inclined and commonly NW-verging folds varying from $\mathrm{cm}$-dm to hm sizes in outcrops. Recumbent $\mathrm{F}_{2}$ folds are not rare. As a consequence, the poles for the $S_{0}$ (and $S_{1}$, too) and $\mathrm{S}_{2}$ foliations define quite similar girdles (Figs. 4a-b; dotted lines labeled $x$ ) in which the higher concentrations of poles in the quadrant SE evidence both the original attitude of the layers and the high degree of fold asymmetry. The existence of $F_{2}$ folds of km-scale in the VETRIA 

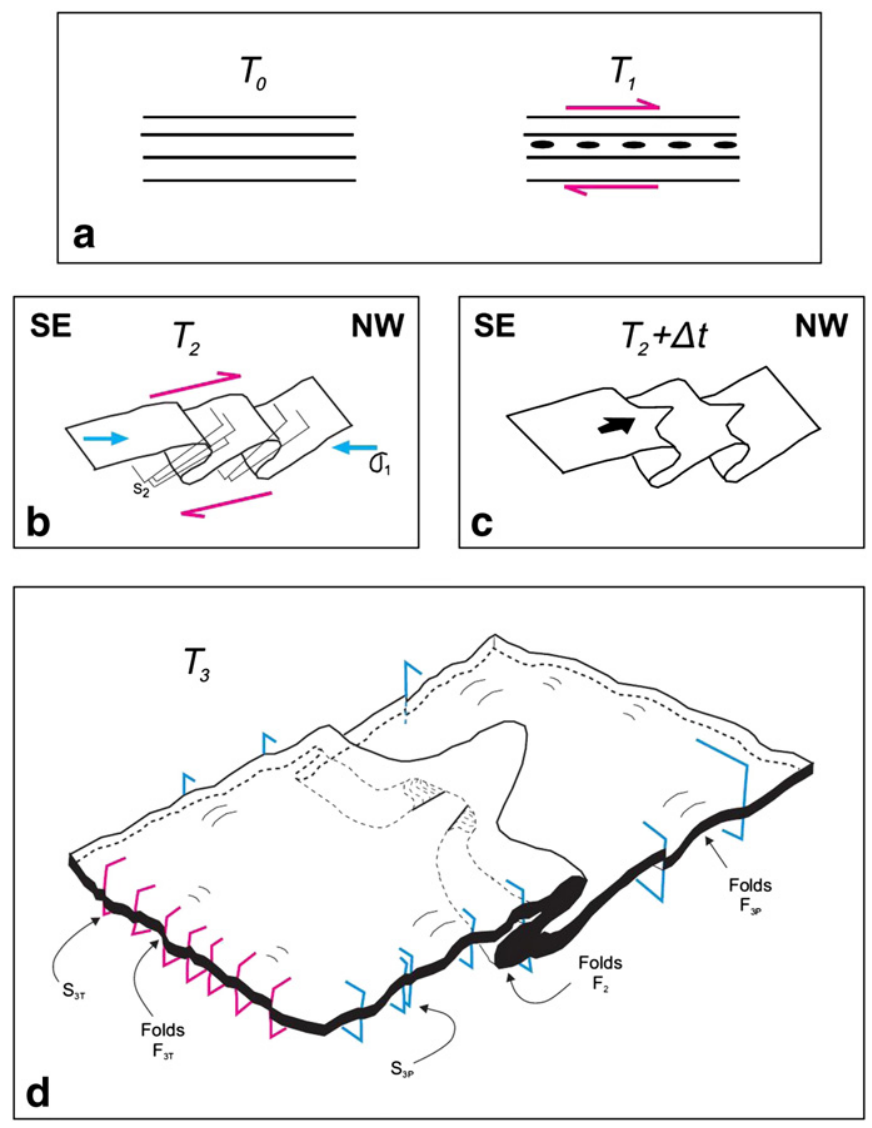

Fig. 13. a-d: Structural evolution of the Jacadigo Group rocks based on data collected in the VETRIA Mine. See Sections 3.1-3.7.

Mine, deduced after a combination of detailed structural data with information from diamond drill holes, and the widespread occurrence dam-hm scale $F_{2}$ folds in the mine benches, emphasize the role of $D_{2}$ ductile flow and $\mathrm{F}_{2}$ folding in the build-up of a large ore reserve in a smaller field area.

The foliation $\mathrm{S}_{2}$ is also quite common in the area. It is basically a slaty cleavage in fine-grained siliciclastic rocks or even in hematite-rich layers, but may appear as sets of very closely spaced surfaces of partition when cutting across more massive layers of carbonate.

Generally the $S_{2}$ foliation dips at low-moderate angles, either to NW or SE (Fig. 4b) the fold axis $\left(b_{2}\right)$ and the intersection lineation $\left(\mathrm{L}_{2-0 / 1}\right)$ plunge gentle-moderately either to NE or to SW (Fig. $4 \mathrm{c}$ ). Nevertheless, NW-SE trending fold axes $b_{2}$ were found far more frequently in Jacadigo Group rocks of the VETRIA Mine and this is the unique difference in the orientation of $D_{1}, D_{2}$, and $D_{3}$ structures across the area. This fact, coupled with the gentle- to moderatelydipping axial surfaces $\left(\mathrm{AP}_{2}\right)$ allows interpreting a ductile migration of the $F_{2}$ hinges towards parallelism with the direction of $D_{2}$ regional ductile flow (sheathing).

\section{4. - Tectonic phase $D_{3}\left(D_{3 P}+D_{3 T}\right)$}

The structures which represent the crustal shortenings $D_{3 P}$ and $D_{3 T}$ deform the bedding $\left(S_{0}\right)$ and also $D_{1}$ and $D_{2}$ structures. They keep the same basic morphological characteristics but differ on their orientations: the folds $F_{3 p}$ and respective axial planar foliation $\left(S_{3 P}\right)$ indicate crustal shortening in the direction NW-SE (co-axial with $\mathrm{D}_{1}-\mathrm{D}_{2}$ ) whereas the folds $\mathrm{F}_{3 \mathrm{~T}}$ and axial planar foliation $\mathrm{S}_{3 \mathrm{~T}}$ indicate shortening in an almost orthogonal direction (SW-NE). However, in Corumbá Group rocks the $D_{3 T}$ shortening is mostly represented by the $S_{3 T}$ foliation and the $\mathrm{F}_{3 \mathrm{~T}}$ folds seem to be less common than in Jacadigo Group rocks where, even the arc-shaped map pattern transected by the Pantanal road (Fig. 2) records the regional importance of $\mathrm{F}_{3 \mathrm{~T}}$ folding.

The folds $\mathrm{F}_{3 \mathrm{P}}$ and $\mathrm{F}_{3 \mathrm{~T}}$ are up-right, often symmetric, $\mathrm{cm}$ - to km-sized and more commonly gentle-open style (e.g. Figs. $11 \mathrm{a}-\mathrm{c}$ ), though the $\mathrm{F}_{3 \mathrm{P}}$ folds commonly attain tighter profiles than the $\mathrm{F}_{3 \mathrm{~T}}$ folds. Our detailed field work showed that the broad folds which trend NE in previous regional maps (Fig. 2) are in reality $F_{3 P}$ folds, well characterized in Corumbá Group rocks (e.g. in the AGESA outcrop; Section 3.6) and also in large exposures of Fe-Mn rocks in the VETRIA Mine.

The axial planar foliations $\left(S_{3 P}\right.$ and $S_{3 T}$ ) are equally very penetrative, generally consist of anastomosed $\mathrm{cm}$-spaced cleavages associated with pressure solution, but may appear locally as $\mathrm{cm}$ - to $\mathrm{dm}$-spaced crenulation cleavages (Figs. 9, 10, and 11). They are both easily recognized in outcrops and promptly distinguished from the $\mathrm{S}_{2}$ slaty cleavage because of the different morphologies and the clear cross-cutting relationships: whereas $S_{3 P}$ and $S_{3 T}$ are both sub-vertical, typically spaced, and commonly cut or crenulate the layers and foliation $S_{2}$ at very high angles.

Because the $F_{3 P}$ folds are more common and are to some extent tighter than the $F_{3 T}$ folds, the girdle corresponding to $D_{3 P}$ shortening is more evident in stereograms of planar features $\mathrm{S}_{0}$ and $\mathrm{S}_{2} / \mathrm{AP}_{2}$ (line $x$ in Fig. 4a-b) than that corresponding to $\mathrm{D}_{3 \mathrm{~T}}$ shortening (line $y$; Fig. 4a-b). This is because $\mathrm{D}_{3 \mathrm{~T}}$ shortening mainly promoted pressure solution and only modified the regional dips (NW or SE) to gentle dips to NE or $S W$. However, the existence $F_{3 P}$ and $F_{3 T}$ folds, so common in mesoscopic scale in the VETRIA Mine, and km-scale in regional sections (Fig. 11), can be also demonstrated by the nearly orthogonal folds axes $\left(B_{3 P}\right.$ and $B_{3 \mathrm{~T}}$ in Fig. 4d) and axial plane foliations $S_{3 \mathrm{P}}$ and $\mathrm{S}_{3 \mathrm{~T}}$ (Fig. $4 \mathrm{c}$ and e, respectively).

Abundant field evidence indicate that $\mathrm{D}_{3 \mathrm{~T}}$ deformation was superimposed upon structures $D_{3 p}$, but there is also evidence that the $D_{3 p}$ shortening lasted alone until the final stages of the evolution of the area, such as in the Marina Gatass outcrop, where one can observe the spaced cleavage $S_{3 T}$ crenulating the foliations $S_{2}$ and $S_{3 p}$ or cutting cross the hinge of $\mathrm{F}_{3 \mathrm{P}}$ folds and being shortened again by a renewed compression $\mathrm{D}_{3 \mathrm{P}}$ (Fig. 12 a-e),

Moreover, because $\mathrm{D}_{3 \mathrm{P}}$ and $\mathrm{D}_{3 \mathrm{~T}}$ shortenings were mutually orthogonal, the surfaces of foliation $S_{3 P}$ lasted sub-parallel to $\sigma_{1-3 T}$, so that some of them were re-used as extensional fractures early in and due to $\mathrm{D}_{3 \mathrm{~T}}$ shortening. Thus, such as exposed in the VETRIA Mine, quartz- or carbonate-veins which occur hosted along such fractures were lately crenulated and/or cut across by the $\mathrm{S}_{3 \mathrm{~T}}$ foliation. Similarly, surfaces of foliation $S_{3 T}$ lasted parallel to $\sigma_{1-3 \mathrm{P}}$ and were re-used as extensional fractures during $\mathrm{D}_{3 \mathrm{P}}$ shortening, as observed in the Laginha Quarry (Section 3.6) where carbonate-veins define extensional fractures hosted along $\mathrm{S}_{3 \mathrm{~T}}$ surfaces which were lately crenulated and/or cut cross by the $S_{3 p}$ foliation. Furthermore, still in the VETRIA Mine's benches, some minor contractional faults can be assigned to late $\mathrm{D}_{3 \mathrm{p}}$ shortening because their attitude and kinematics fit in such shortening and because they cut across all structures, inclusive folds $F_{3 \mathrm{P}}$ and foliations $\mathrm{S}_{3 \mathrm{P}}$ and $\mathrm{S}_{3 \mathrm{~T}}$.

In other words, the evidence strongly suggests that the $D_{3}$ tectonic phase started with crustal shortening in the NW-SE direction $\left(D_{3 P}\right)$, compatible with the contraction of Corumbá and Cuiabá arms of the original R-R-R basin system, continued with the synchronous participation of crossed shortenings $\mathrm{D}_{3 \mathrm{P}}$ and $\mathrm{D}_{3 \mathrm{~T}}$, and ended solely with crustal shortening $\mathrm{D}_{3 \mathrm{P}}$. Reasons for the SW-NE shortening $\left(\mathrm{D}_{3 \mathrm{~T}}\right)$ are discussed in Section 4.2.

\section{5. - Patterns of folding interference}

The few specimens of $\mathrm{F}_{1}$ folds localized in the VETRIA Mine occur coaxially re-folded by $F_{2}$ folds. This pattern (Type 3 of Ramsay, 1967) is also very commonly observed for the interference $F_{3 P} \times F_{2}$ folds in outcrops of Corumbá Group rocks (next section) as well as in Jacadigo rocks of the VETRIA Mine (Fig. 10). 
The superposition of up-right $\mathrm{F}_{3 \mathrm{~T}}$ folds (SW-NE shortening) upon highly asymmetric/recumbent $\mathrm{F}_{2}$ folds with $\mathrm{NW}$ - or SE-plunging axis $\mathrm{B}_{2}$ (most visible in the VETRIA Mine) also resulted in type $3 \mathrm{~F}_{3 \mathrm{~T}} \times \mathrm{F}_{2}$ interference patterns (Fig. 9). However, we did not observe there the interference pattern of Type 2 (mushroom-and-boomerang) which would be expected to form in consequence of the superposition of upright $F_{3 T}$ folds upon $F_{2}$ folds with the $B_{2}$ axis in the original position (NE- or SW-plunging) or up-right $F_{3 P}$ folds superposed upon $F_{2}$ folds with $B_{2}$ axis rotated to NW or SE, most likely because of the larger scale of the majority of the $F_{3 T}$ and $F_{3 P}$ folds when compared to the $F_{2}$ folds scale, or because the mining works have not produced exposures large enough for showing the pattern where superposed folds are both large-scale and occur in a same space within the ore body.

The superposition of $\mathrm{F}_{3 \mathrm{~T}}$ and $\mathrm{F}_{3 \mathrm{P}}$ folds of similar size upon subhorizontal layers would potentially create interference pattern of Type 1 (domes-and-basins) in the study area, and these are actually suggested by the map pattern of the Jacadigo rocks (the hills; Fig. 2). However, such a pattern was not observed in outcrops of Corumbá Group rocks, and only in one place of the VETRIA Mine we could characterize a very gentle hm-scale $\mathrm{F}_{3 \mathrm{~T}} \times \mathrm{F}_{3 \mathrm{P}}$ dome. The general absence of true domes-and-basins may be attributed, at least in part, to the lack of conveniently large exposures and/or to a fortuitous
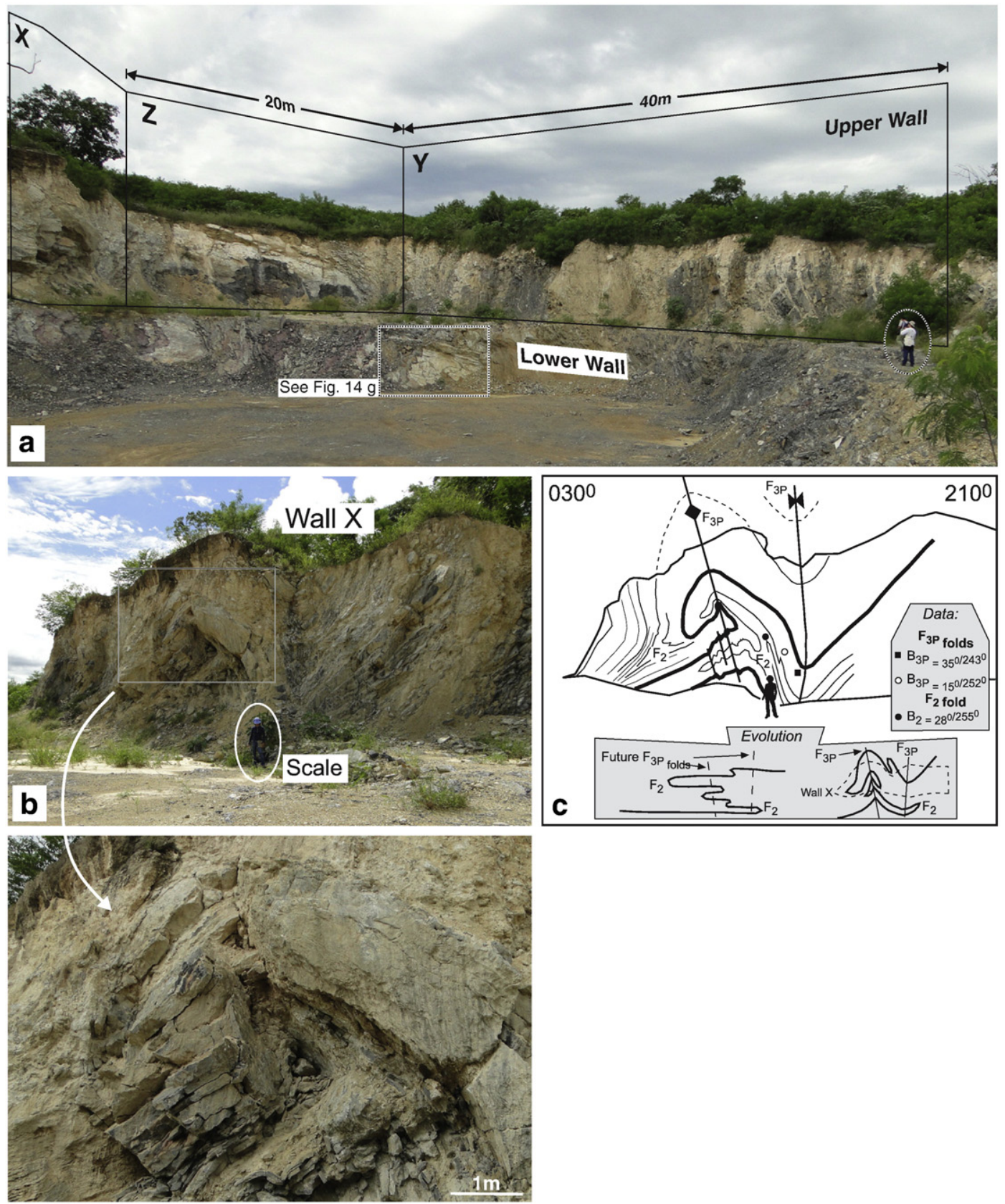

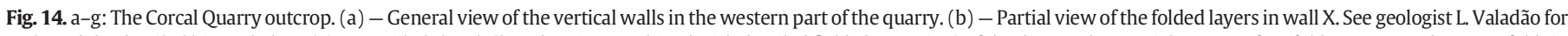

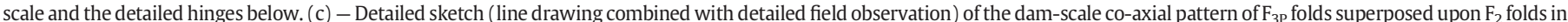

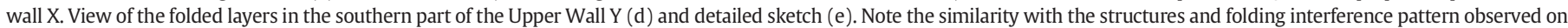

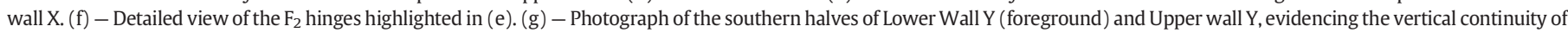
the layers and the down-verging $F_{2}$ folds which deform the carbonate and siltite layers. The $F_{2}$ and $F_{3 p}$ folds highlighted in the upper wall are the same as in (e-f). 

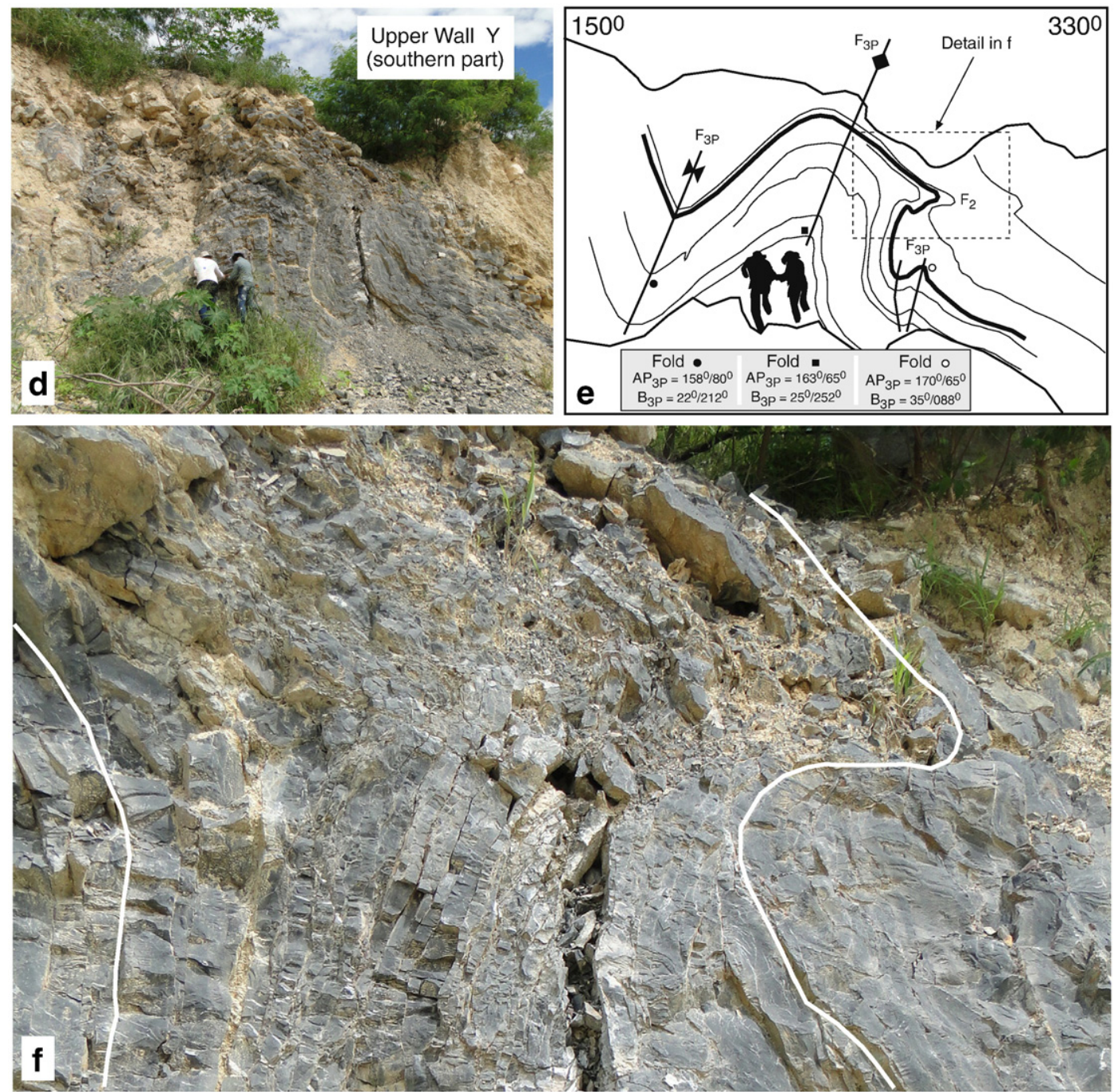

Fig. 14 (continued)

non-coincidence of these folds of similar scale in the sites now exposed on surface.

\section{6. - Key outcrops in the Corumbá area}

After the detailed mapping of tens of outcrops in the VETRIA Mine it is possible to envisage a progressive structural evolution for the Jacadigo rocks (Fig. 13) emphasizing the role of: (1) - the $D_{1}$ deformation for removing the silica and concentrating the iron in the ore (Fig. 13a); (2) - the $\mathrm{D}_{2}$ deformation in the duplication of the layers, a consequence of $\mathrm{F}_{2}$ asymmetric folding and eventual sheathing (Fig. 13b-c); and, (3) the late shortenings $\left(D_{3 P} ; D_{3 T}\right)$ in the production of up-right folds $F_{3 P}$ and $\mathrm{F}_{3 \mathrm{~T}}$, as well as small-scale displacements of the layers along vertical surfaces of axial planar foliations $\left(\mathrm{S}_{3 \mathrm{p}}\right.$ and $\mathrm{S}_{3 \mathrm{~T}}$; Fig. 13d).

Apart from minor differences (the intensity of $S_{1}$ foliation and rotation or not of the $B_{2}$ folds axis) a similar structural evolution is evidenced for the Corumbá Group rocks, for example in the large-scale 3-D exposures described below.

The Marina Gatass outcrop (427.625 E; 7.897.705 N; Z21S; Datum WGS84) a leisure/tourism place situated along the southern margin of the Tamengo Channel (tributary of the Paraguay River), NW limits of the Corumbá city (Fig. 2), exposes a sequence of cm-thick layers of siltite and shale (Tamengo Formation) locally displaying the $S_{1}$ foliation (platy minerals sub-parallel to bedding) and affected by dm-scale recumbent
$\mathrm{F}_{2}$ folds and the $\mathrm{S}_{2}$ slaty cleavage, and all these features occur shortened by a spectacular series of $\mathrm{dm}$-scale, NE-trending $\mathrm{F}_{3 \mathrm{P}}$ folds and a quite penetrative pressure solution-type and $\mathrm{cm}$-spaced cleavage $\left(\mathrm{S}_{3 \mathrm{P}}\right)$. The mutual cross cut relationships between foliations, such as $S_{3 \mathrm{~T}} \times \mathrm{S}_{2}-\mathrm{S}_{3 \mathrm{P}}$ (Fig. 12a-b) and $\mathrm{S}_{3 \mathrm{p}} \times \mathrm{S}_{3 \mathrm{~T}}$ (Fig. 12c-e) are evident in the outcrop.

The AGESA outcrop (427.700 E; 7.896.547 N; Z21S; Datum WGS84) is a SE-NW trending road-cut nearby the office of the water supply state company (AGESA). Most of the outcrop's length ( 100 m) displays m-thick layers of white/light gray dolomite (Bocaina Fm; Corumbá Group) turning around the hinge of a hm-scale, gentle/open, NEtrending, up-right $\mathrm{F}_{3 \mathrm{p}}$ antiform. However, in the outcrop's northwestern end the dolomite pass northwestwards into Tamengo (meta)rhythmite, the whole sequence becomes progressively sub-vertical and is cut by small thrust faults dipping $\sim 50^{\circ}$ to $\mathrm{SE}$, implying just little or none displacement, and possibly representing the damage zone ahead of the tip point of a blind thrust. The outcrop corresponds to a large fault-propagation $F_{2}$ fold with the long limb re-folded $F_{3 P}$ (Fig. 5).

The Corcal Quarry (428.086 E; 7.896.985 N; Z21S; Datum WGS84) lies very close to Corumbá southwest and exposes Tamengo carbonate, marl, and siltite, topped by Guiacurus siltite. After detailed mapping, the walls in the quarry's southwestern part (Fig. 14a-g) revealed the control exerted by sub-hm scale and NW-verging $\mathrm{F}_{3 \mathrm{P}}$ folds and co-axially refolded $\mathrm{F}_{2}$ folds (recumbent, dam-scale; Fig. 15a-c) upon the layer's geometry (see also Fig. 5). 


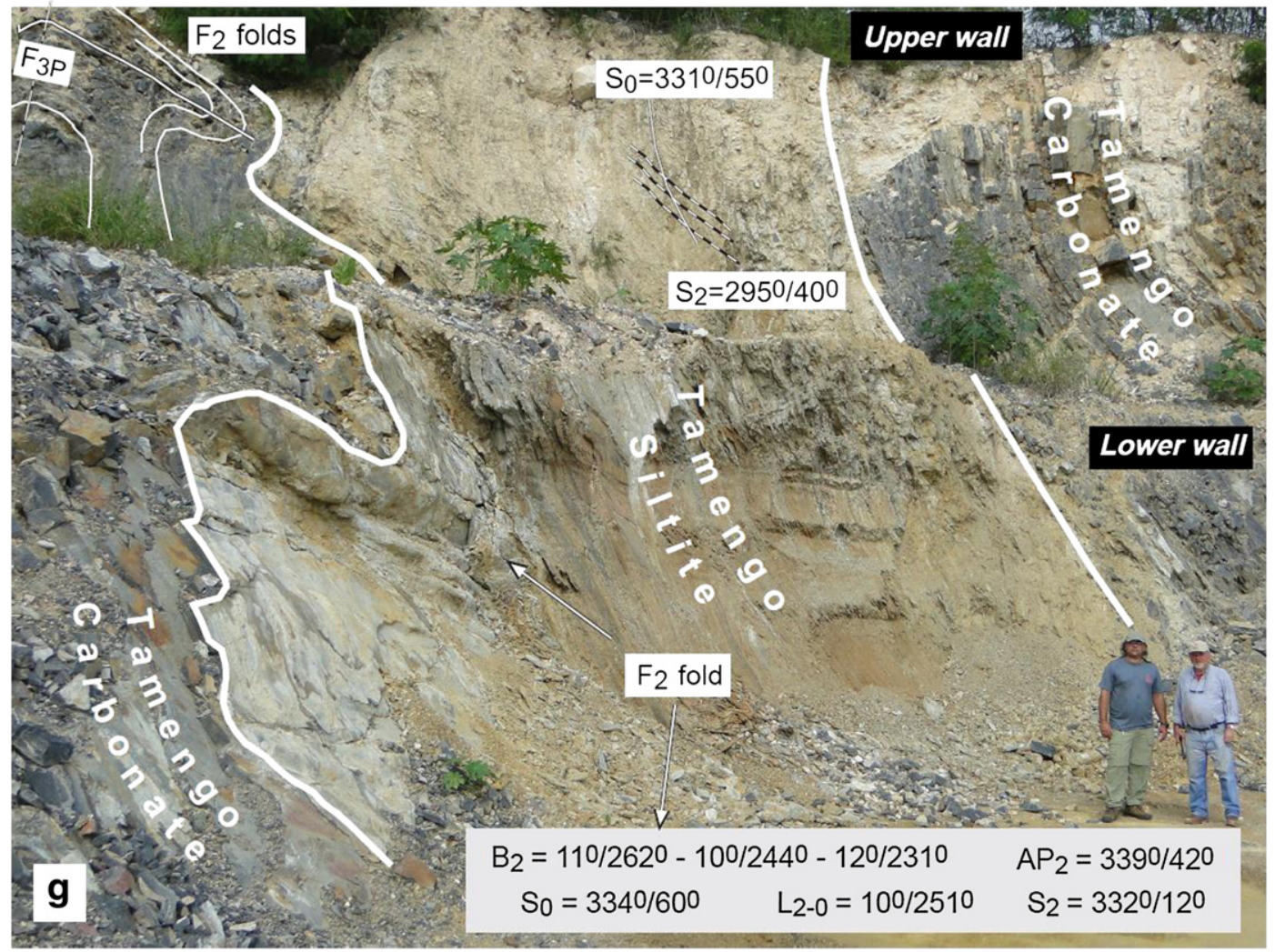

Fig. 14 (continued).

The Cacimba da Saúde outcrop lies on the bottom of the E-W cliff trending parallel to the southern margin of the Tamengo Channel and Paraguay River and separating the lower from the upper Corumbá city. It encloses two main sites, $\sim 50 \mathrm{~m}$ apart from each other. Similarly as in the outcrops described above, the easternmost site (429.861 E; 7.889.153 N; Z21S; DATUM WGS84) exhibits sub-dam scale $F_{2}$ recumbent folds co-axially shortened by $F_{3 P}$ folds and a strong pressure solution foliation $\left(\mathrm{S}_{3 \mathrm{P}}\right)$ evident in the more siltic layers (Fig. 16a-c).

\section{7. - Faults in the Corumbá area}

Even being an area of about $1 \mathrm{~km}^{2}$, in which tens of almost continuous outcrops were opened during the mining works, the VETRIA Mine revealed that faults are not expressive in the Jacadigo rocks, exception for some thrusts associated with large-scale asymmetric-recumbent $F_{2}$ folds existing there. However, the few thrust faults observed are minor/local faults (Fig. 17) and the single example of normal fault noticed in the field (443.155 E; 7.869.539 N; Z21S; DATUM WGS84) is a $\mathrm{m}$-scale, top-down to SE normal fault $\left(=116^{\circ} / 44^{\circ}\right)$ cutting the northwestern limb of a decameter-scale $\mathrm{F}_{3 \mathrm{P}}$ fold and fitting, for its attitude and kinematics, an Anti-Riedel shear fracture associated with $\mathrm{D}_{3 \mathrm{P}}$ shortening.

The $400 \mathrm{~m}$-long western wall of the uppermost bench of the Laginha Quarry outcrop (427.700 E; 7.896.547 N; Z21S; Datum WGS84) exhibits a set of nine Anderson-style thrust faults sub-parallel to the layers of Tamengo carbonate which contain minor intercalations of siltstone layers and dominate throughout the section, defining a homoclinal structure dipping $\sim 30^{\circ}-40^{\circ} \mathrm{SE}$ (Fig. 18a). The carbonate layers are conformably overlain by light brown siltite in the southernmost part of the section and occur tectonically juxtaposed onto basal diamictite in the northern end. In the field, the $S_{2}$ foliation is normally evident in the siltstone layers but is hard to see in the carbonate rocks, whereas the $\mathrm{S}_{3 \mathrm{P}}$ foliation is visible throughout the section. Some of the faults' surfaces are marked by thin veins of calcite displaying spectacular indicators such as down-dip striations and steps, en-echelon tension gashes, or S-C foliations (Fig. 18b-f) all demonstrating the dip-slip reverse kinematics.

The thrust faults in the Laginha Quarry could be either $D_{2}$ or $D_{3 P}$ structures, perhaps even $D_{2}$ faults re-worked during $D_{3 P}$ shortening, but at least one (Fig. 18e) may be interpreted as an expression of late$\mathrm{D}_{3 \mathrm{P}}$ shortening because it clearly displaces $\mathrm{S}_{3 \mathrm{P}}$ surfaces marked by calcite veins, seeming extension fractures which opened along $S_{3 P}$ in consequence of $\mathrm{D}_{3 \mathrm{~T}}$ orthogonal shortening.

In the northernmost $50 \mathrm{~m}$ of the section (Fig. 18a), the carbonate layers are rich in carbon material and preserve the homoclinal structure, although to a certain extent they are partially substituted by decimetercentimeter sized blocks dispersed chaotically in a matrix of carbon-rich material and brown-color soil material, resembling a zone of breccia. The limit between layers and breccia is diffuse, however. Some blocks enclose dm-sized irregular-shaped bodies of calcite or carbon rich material, and $\mathrm{cm}$-sized crystals of fluorite. Closer to the polished but striation-free surface that defines the contact with the diamictite, the continuous and not continuous layers fo carbonate are intensely cut by sets of fractures. Thus, if the breccia could suggest a younger pulse of faulting (of any kinematics) at an upper crustal level, there is not a single change in the dip of the layers from outside to inside the breccia zone, and not a single drag-fold that could support such interpretation. Moreover, percolation of water across highly fractured layers rich in carbon could produce local collapse and the appearance of a breccia zone within layers still in situ.

The western site in the Cacimba da Saúde outcrop (429.752 E; 7.889.094 N; Z21S; Datum WGS84) exhibits polyfolded ( $F_{2}$ and $\left.F_{3 P}\right)$ layers of Tamengo carbonate displaced along a SW-NE trending, sharp, wavy and sub-vertical surfaces of what firstly resembles a (topdown-to SE) normal fault or perhaps a transcurrent fault with component of vertical slip (Fig. 19a).

However, we argue that the normal faulting is apparent, only the vertical slip is real, being rather a consequence of a contraction- 
induced vertical adjustment of layers along surfaces of the $S_{3 P}$ foliation in the limb-hinge of gentle regional $\mathrm{F}_{3 \mathrm{P}}$ folds affecting a thick carbonate sequence. In other words, due to a combination of pressure solution during initial buckling with pop-up and pop-down of blocks during the subsequent folding.

Our interpretation has supports: the wavy surface post-dates the $F_{2}$ folds and its general attitude $\left(290^{\circ} / 80^{\circ}\right)$ fits the attitude of the $S_{3 P}$ surfaces; the lack of striations on the wavy surface and the apparently discrepant kinematics (Fig. 19a) may be easily explained by the effects of pressure solution during $D_{3 p}$ shortening; the wavy surface and its general attitude both fit the expected characteristics of surfaces sub-perpendicular to the maximum compressive stress $\sigma_{1}-3$ p (see Fig. 19c); and the apparent vertical displacement of the layers due to pressure solution associated to $D_{3 P}$ shortening $\left(D_{3 T}\right.$, as well) are common in the study area.

In reality, the abundance and scale of $F_{2}$ folds (Fig. 16) in the Cacimba da Saúde outcrop and the gentle dip of the layers to NW (Fig. 19a) allow definition of sub-hm $\mathrm{F}_{2}$ folds in the northwestern limb of a large (km-scale?) $F_{3 p}$ fold associated to strong pressure solution along sub-vertical surfaces $S_{3 p}$, one of these coinciding locally with the cliff's wall.

Situated still on the bottom of the vertical cliff along the southern margin of the Paraguay River, the Marina Limoeiro outcrop (433.527 E; 7.899.234 N; Z21S; Datum WGS84) displays layers of Tamengo carbonate dipping gently to NW and affected by $\mathrm{D}_{2}$ and $\mathrm{D}_{3 \mathrm{P}}$ structures (Fig. 19b) and these are cut by vertical sinistral transcurrencies suborthogonal to the cliff (details in the figure caption), a template clearly repeated in the Sopramil Harbor outcrop situated nearby (434.733 E; 7.898.963 N; Zone 21S; DATUM WGS84).

\section{Discussion and conclusions}

\subsection{Structural/metamorphic evolution in the Corumbá area}

The abundant tectonic structures observed in several, large-scale, 3D outcrops, allow a clear description of the structural evolution of the Neoproterozoic-Cambrian rocks in the Corumbá area according to a polyphased deformation $\left(D_{1}-D_{3}\right)$ and sub-greenschist facies regional metamorphism.

Phase $D_{1}$, performed by inter- and intra-layers ductile flow, resulted mostly in a pervasive foliation (sub-)parallel to bedding, quite penetrative in Jacadigo iron-formation rocks and far less penetrative in Corumbá Group rocks. Although more data are necessary for a better characterization of this phase as a truly regional deformation, the evidence of $D_{1}$ intra-stratal flow are clear enough, as well as the independence of this from $D_{2}$ ductile flow. Furthermore, the $S_{1}$ foliation is undoubtedly the record of the low-grade sub-greenschist metamorphism (fine-grained white mica and other platy minerals) whereas the $S_{2}$ slaty cleavage and the $D_{3}$-related spaced cleavages likely record a progressive lowering of the temperature conditions.

Phase $D_{2}$ implies a regime of low-angle frontal ramps and a reversesense kinematics with a relative movement of the top to NW. The lack of differently oriented intersection lineations imprinted volumetrically on the surface of the layers and attributable to $D_{2}$ and $D_{1}$ phases (not forgetting that the $\mathrm{D}_{3}$ intersection lineations are clearly spaced features that cannot be mistaken as $D_{2}$ or $D_{1}$ features) strongly suggests that $\mathrm{D}_{2}$ and $\mathrm{D}_{1}$ ductile flows were actually co-axial. Phase $\mathrm{D}_{3 \mathrm{P}}$, mostly characterized by up-right (or slightly verging to $\mathrm{NW}$ ) $\mathrm{F}_{3 \mathrm{P}}$ folds and strong axial planar foliation $\left(\mathrm{S}_{3 \mathrm{P}}\right)$, implies crustal shortening in the same direction as

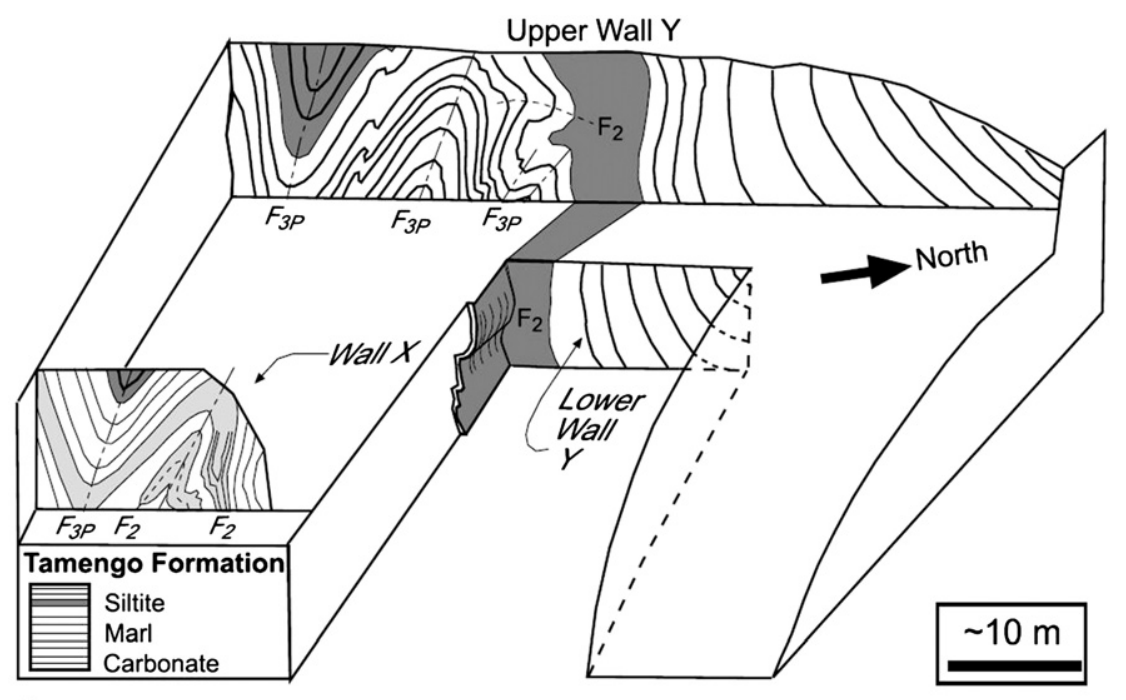

a
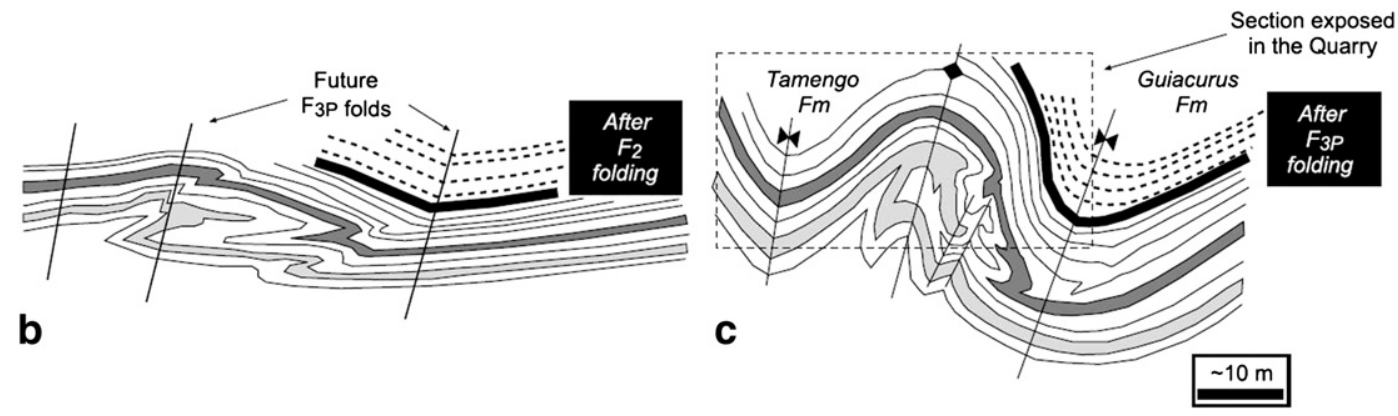

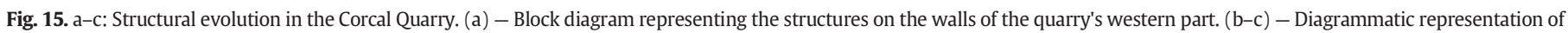
the $\mathrm{D}_{2}-\mathrm{D}_{3 \mathrm{P}}$ structural evolution of the Corumbá Group rocks. 

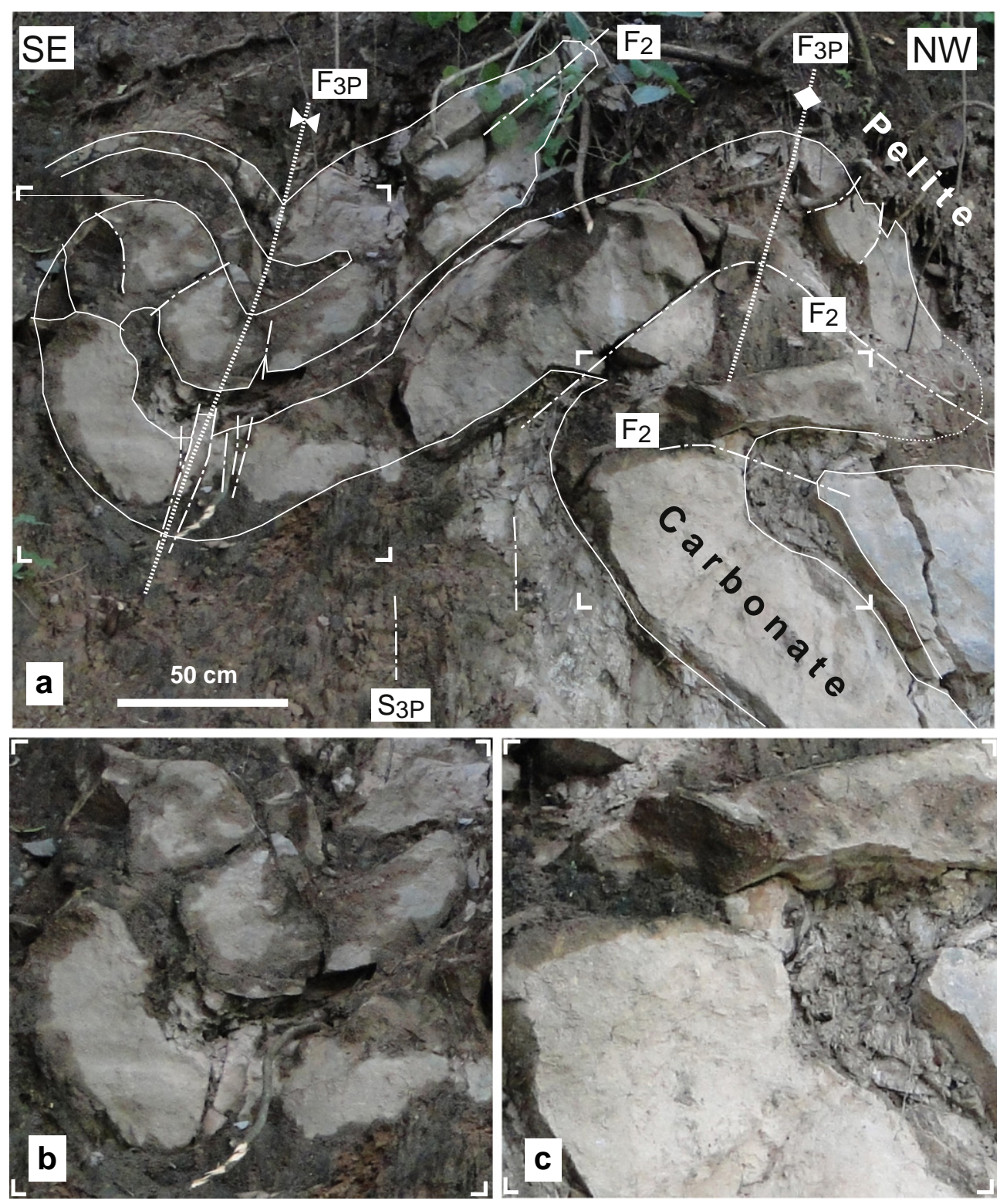

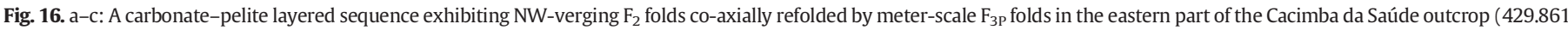

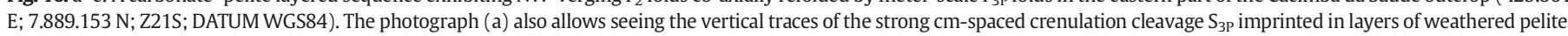
Detailed view of the framed parts are shown in (b) and (c).

$\mathrm{D}_{1}-\mathrm{D}_{2}$ (SE-NW) and co-axial refolding of the $\left(\mathrm{F}_{1}\right) \mathrm{F}_{2}$ folds. Phase $\mathrm{D}_{3 \mathrm{~T}}$ imprinted structures similar to the $\mathrm{D}_{3 \mathrm{p}}$ ones but implies shortening in the SW-NE direction, coevally to but ending earlier than $\mathrm{D}_{3 \mathrm{P}}$ shortening.

For their attitude and dip-slip kinematics, the thrust faults (Laginha Quarry; VETRIA Mine) are typical frontal ramps, consequence of $D_{3 P}$ regional shortening for which the sub-horizontal maximum stress $\left(\sigma_{1-3 \mathrm{P}}\right)$ is oriented SE-NW, similarly as $\sigma_{1}$ responsible for $F_{2}$ folds and $D_{2}$ contractional faults. As indicated in Fig. $19 \mathrm{c}$, the $\mathrm{D}_{3 \mathrm{P}}$ compression also accounts for the NNW-trending transcurrencies (Marina Limoeiro and Sopramil Harbor outcrops) and for conjugated pairs of large-scale oblique fractures interpreted as formed by these transcurrencies and the set of E-W trending regional fractures which control the course of the Paraguay River (and the Tamengo Channel) in several parts across the Pantanal area, particularly along the northern edge of Corumbá city.

As such, a progressive deformation (Brasiliano Cycle) accounts for all the ductile and brittle structures observed in outcrops of the Corumbá area. Moreover, the fact that the basal Jacadigo rocks rest $500 \mathrm{~m}$ higher in the topography is not a consequence of large-scale normal faulting, either Neoproterozoic-Cambrian or even any younger regional extensional event that could be potentially responsible for the Pantanal lowlands and/or for the Paraná basin.

The participation of the crystalline basement in the deformation of the Corumbá area supracrustals is real, although poorly documented. As a rule, the basement rocks are extremely weathered across the area, but in a very small exposure on the ground of the Pantanal road, in a site not occasionally situated exactly in the core of the $\mathrm{D}_{3 \mathrm{~T}}$-related arc of Jacadigo rock (NE of the VETRIA Mine; Fig. 2) the orthogneiss exhibits an NE-striking sub-vertical greenschist facies foliation that is compatible with the $D_{2}-D_{3 P}$ contraction of the cover. Furthermore, Litherland et al. (1989) reported the refoliation of crystalline basement rocks and the 546-501 Ma $\mathrm{K}-\mathrm{Ar}$ isotopic resetting of these during the Brasiliano deformation in the Tucavaca aulacogen, therefore entirely compatible with the interval for deformation and final cooling of the Corumbá supracrustals (Piacentini et al., 2013). Moreover, the positive 

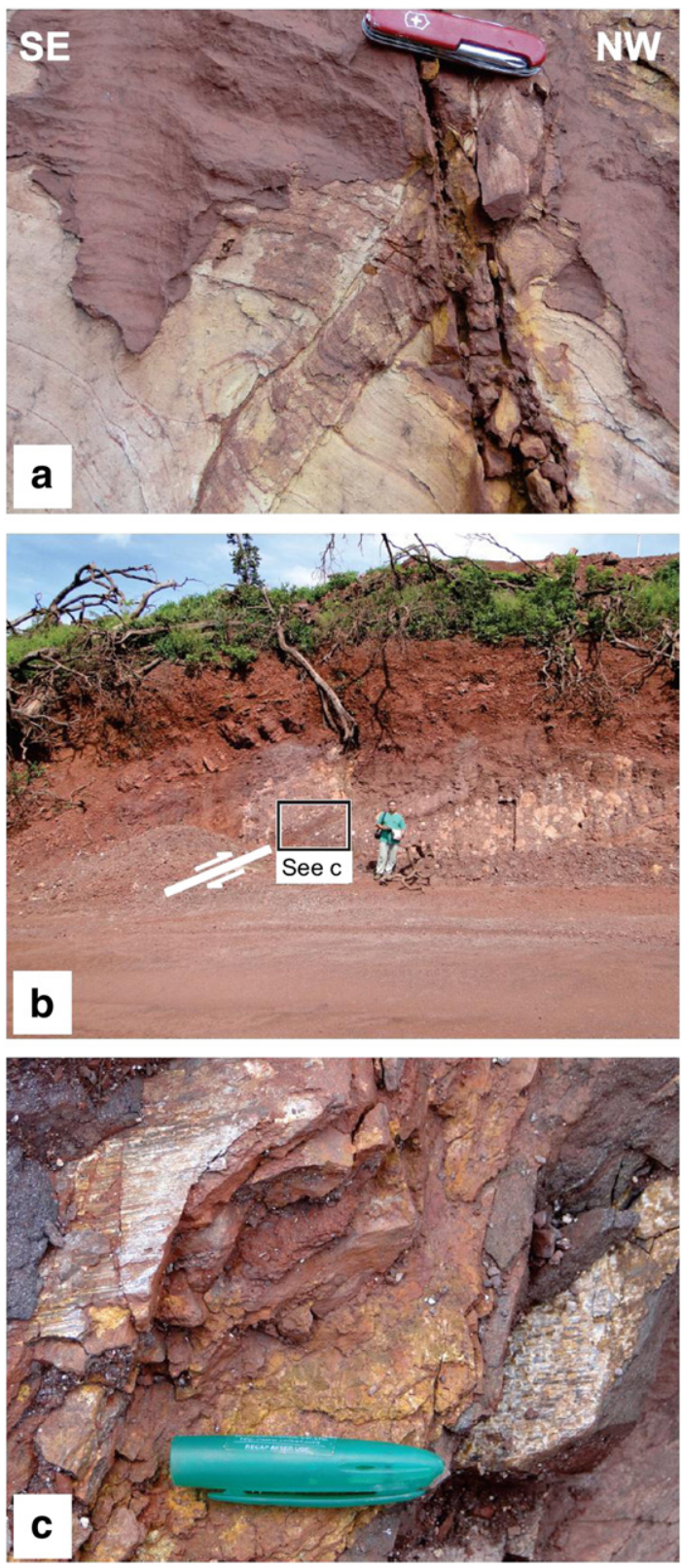

Fig. 17. a-c: Contractional faults in Jacadigo Group Rocks. (a) - A NW-verging reverse fault associated with an asymmetric $\mathrm{F}_{2}$ antiform which deforms layers of sandstone and pelite, in a road-cut (445.178 E; 7.869.748 N; Z21S; Datum WGS84) close to the VETRIA Mine's entrance. Surfaces of a spaced cleavage $\left(S_{3 \mathrm{p}}=120^{\circ} / 80^{\circ} ; 135^{\circ} / 90^{\circ}\right)$ evidence pressure solution during $\mathrm{D}_{3}$ crustal shortening superposed upon the folded layers and the fault. (b) - A thrust fault parallel to layers of siltite in a ferriferous diamictite (VETRIA Mine - 443.384 E; 7.869.665 N; Z21S; Datum WGS84). Due to the SW-NE compression, the layers and the fault (attitude $258^{\circ} / 31^{\circ}$ ) dip to WSW, as part of the limb of a decameter-scale $\mathrm{F}_{3 \mathrm{~T}}$ fold (not shown). However, striations with attitude $20^{\circ}$ $134^{\circ}$ observed on the fault surface [detail in (c)] indicate an SE-to-NW slip compatible with the regional kinematics ( $D_{2}$ deformation)

inversion of grabens necessarily involves the contraction of the basement (such as in Fig. 8 by Campanha et al., 2011).

Thus, sub-horizontal stresses which certainly existed across the Amazon-Rio Apa continental crust could have shortened the crystalline basement and inverted the normal faults in the Jacadigo rift, and this happened during $\mathrm{D}_{2}-\mathrm{D}_{3 \mathrm{p}}$ deformation, likely.

The higher topographic level of the iron formation hills $(\sim 1000 \mathrm{~m}$; Fig. 2) and the $F_{2}$ sheaths that are strongly suggested to exist in the VETRIA Mine may be explained because the inversion of rift basins usually results in that rift-bottom layers move out of the depocenter, onto the rift shoulders (e.g., Marques et al., 2014) and basin inversion is commonly accompanied by nape-like extrusion of the layers (experiments by McClay and Buchanan, 1992). If so, the highly anisotropic packet of iron-bearing layers (Fig. 7c) would have facilitated a more intense ductile flow in the Jacadigo rocks and the differential propagation (potential sheathing) of the $\mathrm{F}_{2}$ asymmetric hinges. The abundant data in the VETRIA Mine point to the sub-vertical surfaces associated to the gentle $F_{3 P}$ antiform defined by the iron formation-topped hills (Fig. 11a) as $\mathrm{D}_{3 \mathrm{P}}$-related contractional faults similar to the one in the Cacimba da Saúde outcrop (Fig. 19a). Thus, although regional extensional faults are no longer seen in the field, the original normal faults of the basin may have been preferential sites for $\mathrm{D}_{3 \mathrm{p}}$-related pressure solution and/or vertical displacement due to adjustment of blocks in the outer arc of a broad fold (see indication in cross section AB; Fig. 2). Furthermore, if the reconstruction of the layers above the current surface strongly suggests the Corumbá Group rocks as high as $1000 \mathrm{~m}$, exactly in the Laginha outcrop (see cross-section in Fig. 5) that is the closest to the iron formation-topped hills (Fig. 2), then the contribution of erosion at different ratios should be considered for explaining the topography in the Corumbá area. An idealized regional cross-section (such as in Fig. 6 of the companion paper; Part II) may account for all the syn- and post-deformation factors mentioned above as being responsible for the field template in the Corumbá area.

Finally, the weaker shortening $\mathrm{D}_{3 \mathrm{~T}}$ in the Corumbá Group rocks may be just apparent, perhaps a simple consequence of the lack of studies in more continuous outcrops. Otherwise, if it is real, may be in part attributed to the stiffness (probably enhanced after $D_{1}-D_{2}-D_{3 P}$ deformations) of the Bocaina Fm dolomite layers.

\subsection{Regional implications and conclusion}

The $\mathrm{D}_{1}-\mathrm{D}_{3 \mathrm{P}}$ co-axial deformation and the vergence of the asymmetric folds and thrusts implying a transport of cratonic platformal rocks in the Corumbá area towards the NW (Fig. 1b) compare very well with what Campanha et al. $(2010,2011)$ reported for the Bodoquena Range area, in which cratonic platform (Corumbá Group) and also slope to external slope deposits (Puga-Cuiabá rocks) were transported towards the Rio Apa block (Fig. 1b). The pattern of sub-greenschist metamorphism is recorded in both areas, as characterized in the Corumbá area by white mica sub-mm grains (this work; Piacentini et al., 2013) and chlorite in the Bodoquena area (Campanha et al., 2010, 2011).

However, although the cratonwards tectonic transport in the southern Paraguay belt supports what Almeida (1964) suggested for the entire belt and also fits in the NW-verging thrusts and asymmetric folds affecting the supracrustal rocks and crystalline basement throughout the Araguaia belt (e.g. Herz et al., 1989), most of the tectonic structures in other parts of the Paraguay belt implies tectonic transport to SE. Vergence vectors pointing to SE (Fig. 1b) have been reported for Cuiabá Group rocks, for example in the surroundings of Cuiabá city, according to Alvarenga and Trompette (1993) and D'el-Rey Silva (1990a,b) and also across the narrow $\mathrm{N}-\mathrm{S}$ strip situated well in the middle of the Pantanal basin (the Cuiabá-Bonito strip mentioned below), according to Godoy et al. (2010).

In a broad view, Alvarenga and Trompette (1993) characterized three structural zones in the northern belt. In a NW-SE cross-section (their Fig. 2), the westernmost cratonic platform zone is characterized by non-metamorphic rocks of the Puga, Araras and Alto Paraguay unities affected by broad up-right folds and (likely Cretaceous) vertical normal faults; the external zone (or Serrana domain; Almeida, 1964) comprises rocks of the Puga-Cuiabá, Araras and from the Raizama and Diamantino formations (Alto Paraguay Group), affected by open upright folds and sub-vertical reverse faults, and very low-anchizone metamorphism; and the internal zone that covers since $\sim 50 \mathrm{~km}$ West of Cuiabá until the easternmost exposed rocks of the belt and encloses poly-deformed $\left(D_{1}-D_{3}\right)$ Puga-Cuiabá siliciclastics and Araras carbonates affected by asymmetric folds and thrusts verging to SE. This valid scenario is somehow more complex, however. 


\section{Laginha Quarry}
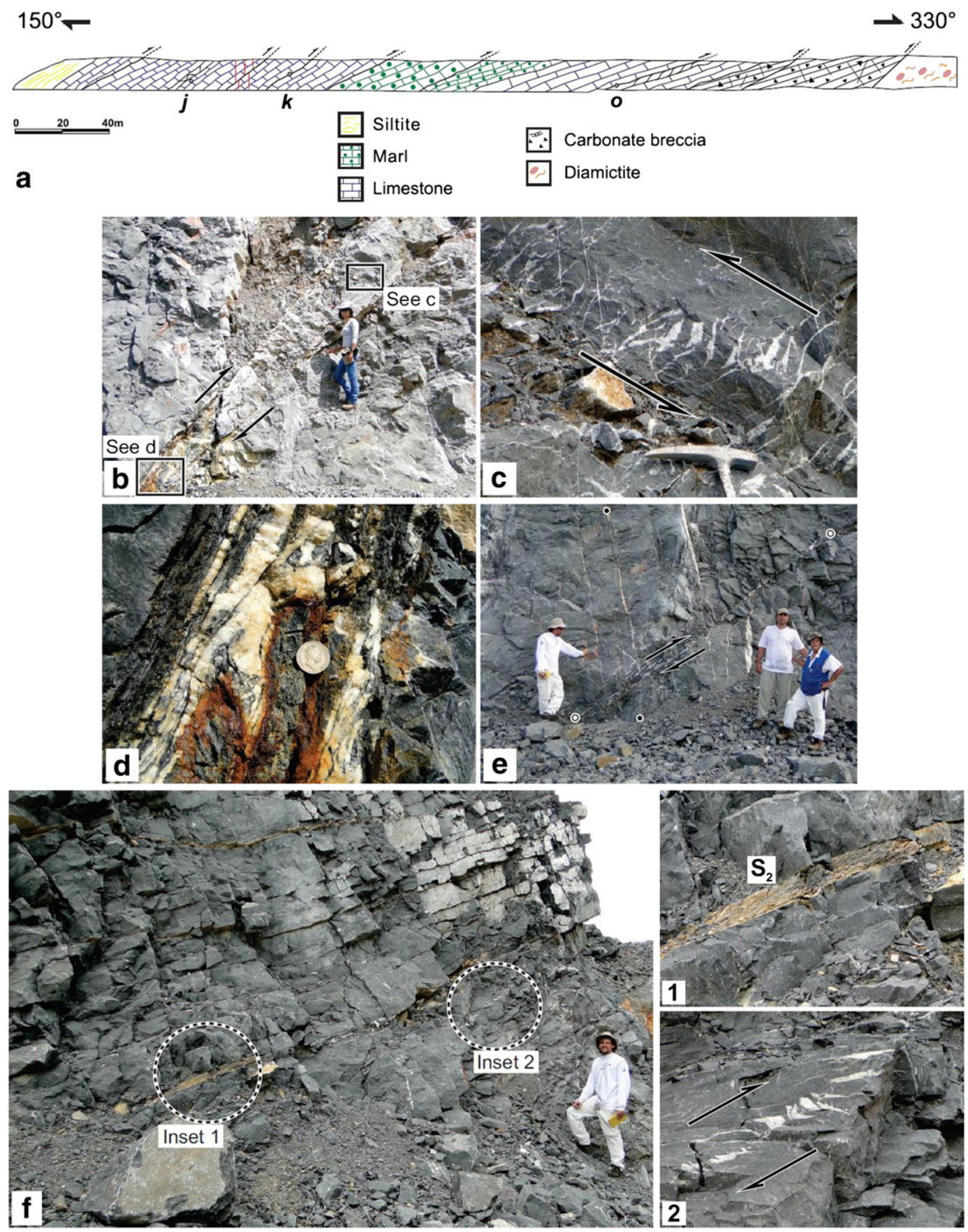

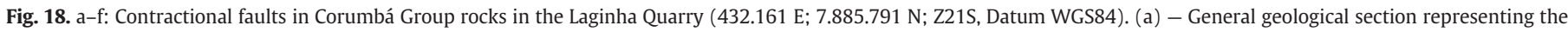

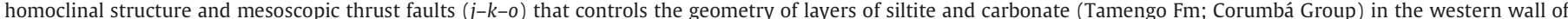

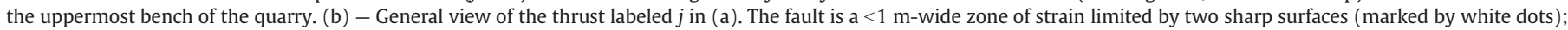

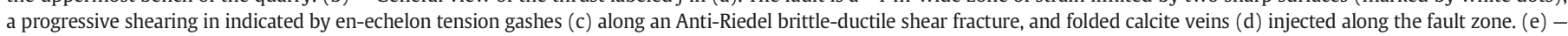

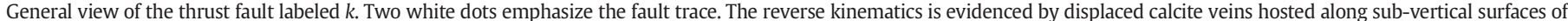

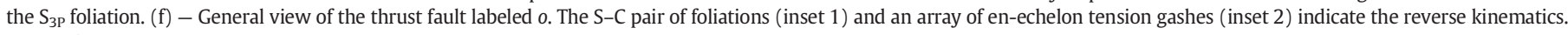
See Section 3.7.

For example, a series of geological sections across the external zone (Serrana domain) north-northwest of Cuiabá (Abreu Filho and Luz, 1977) implies at least two NW-verging events of folding. However, SW of Cuiabá but in the adjacent internal zone, Luz et al. (1980) described co-axial $D_{1}-D_{3}$ shortenings in which a layer-parallel $S_{1}$ foliation (greenschist facies; SE-dipping; enhanced by table-like quartz veins) and isoclinals $F_{1}$ folds verge to NW and are co-axially refolded by asymmetric and $S E$-verging $F_{2}$ folds, being the whole packet affected by up- right $F_{3}$ folds, whereas further South, in the same internal zone, subhorizontal thrusts and coeval, SE-verging asymmetric-recumbent intrafolial $F_{1}$ folds and the layer-parallel biotite-marked $S_{1}$ foliation are co-axially deformed by strongly-inclined $\mathrm{NW}$-verging $\mathrm{F}_{2}$ folds and $\mathrm{D}_{3}$ strike-slip reverse faults (Vasconcelos et al., 2015).

Furthermore, three Au-mines aligned NE-SW in Cuiabá Group rocks (Torrado-Vilela and Portuguese, SW of Cuiabá; and Casa de Pedra, NE of Cuiabá) evidenced to D'el-Rey Silva (1990a,b) a structural evolution 

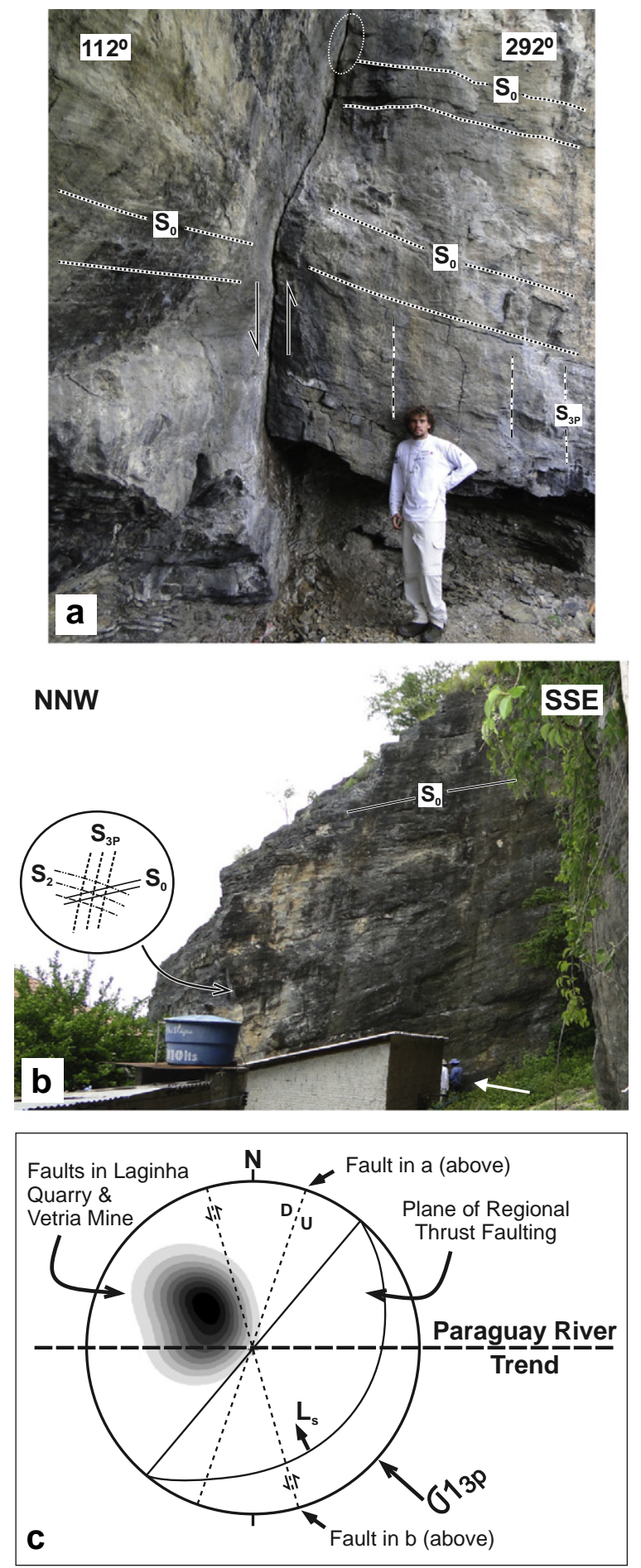

Fig. 19. a-c: Apparent and real faults in the Corumbá area. In the western part of the Cacimba da Saúde outcrop (a) a sub-vertical wavy surface displaces layers of Tamengo Fm carbonate and also $\mathrm{m}$-scale $\mathrm{F}_{2}$ folds (not visible but existing in the lower part, behind geologist $\mathrm{V}$. Katalinic) which are co-axially shortened by gentle $\mathrm{F}_{3 \mathrm{P}}$ folds and anastomosed surfaces of foliation $S_{3 p}$. Only the lower half of the outcrop is shown. The template suggests a topdown to SE normal fault, but striations and steps are virtually absent on the large area of exposure of the wavy surface and subtle drag folds in the northwestern block (inside the ellipse) suggest apparently discrepant kinematics during a potential faulting. In the cliff adjacent to the Marina Limoeiro harbor (b) the layers of Tamengo carbonate $\left(\mathrm{S}_{0}=334^{\circ}\right.$ \% $20^{\circ}$ ) are cut by a vertical sinistral transcurrency $\left(260^{\circ} / 90^{\circ}\right)$ corresponding to the frontal wall behind the small house. Note the traces of the spaced cleavage $S_{3 p}$ (visible in the picture) and the slaty cleavage $S_{2}$ (evident only in the field). The fault kinematics is given by striations $\left(20^{\circ} / 340^{\circ} ; 40^{\circ} / 340^{\circ}\right)$ and a sigmoidal-shaped foliation (strong, sub-vertical, characterized by oriented plate-like clay minerals) of a typical S-C pair, all visible in the arrowed site. (c) - Lower hemisphere (equal-area net) composite stereogram for contractional and transcurrent faults in the study area. See Sections 3.7 and 4.1. starting with a penetrative, layer-parallel sericite-marked $S_{1}$ foliation and (very few) $F_{1}$ intrafolial folds, and following progressively with thrusts and $\mathrm{F}_{2}$ folds co-axially refolded by $\mathrm{F}_{3}$ folds ( $=\mathrm{F}_{3 \mathrm{P}}$; this paper), all verging to $\mathrm{SE}$, and having been the Au-bearing quartz veins injected throughout $\mathrm{D}_{1}-\mathrm{D}_{3}$, the largest ones in a regional swarm of sub-vertical ac-type extensional fractures that record, together with minor folds transversal to the NE-SW structural grain, a so-called $\mathrm{D}_{4}$ deformation or late- $\mathrm{D}_{3}$ tectonic escape (similar to $\mathrm{D}_{3 т}$ ?). Silva et al. (2002) also described SE-verging folds and thrusts in the same Portuguese (or Abdalla) mine.

The pattern above extends until the easternmost part of Paraguay belt, in the Nova Xavantina area (Fig. 1a), where Cuiabá Group metavolcanic-sedimentary rocks were thrust onto the Goiás magmatic arc, as demonstrate low-moderately NW-dipping thrusts and SEverging $F_{2}$ asymmetric folds co-axially refolded $F_{3}$ (L.J.H. D'el-Rey Silva - unpublished consultancy report 2007-2008 for the Caraíba Mining Company, owner of the Araés Au-mine at that time).

Similarly, the Cuiabá Group rocks in the Cuiabá-Bonito strip display $\mathrm{D}_{1}$ greenschist metamorphism (biotite zone), $\mathrm{D}_{1}-\mathrm{D}_{3}$ co-axial shortening and tectonic transport to $\mathrm{SE}$, and late- $\mathrm{D}_{3}$ strike-parallel slip that caused mylonitization along $\mathrm{S}_{3}$ surfaces steepling dipping to WNW (Godoy et al., 2010; and references therein). These authors refer to the Sonora, Coxim, Rio Negro, and Taboco granites as I-type, syn-tectonic sheetlike bodies intruded $\sim 548-540 \mathrm{Ma}$ (zircons U-Pb crystallization ages) along the $\mathrm{S}_{2}$ foliation and promoters of late- $\mathrm{S}_{2}$ contact metamorphism lately overprinted by the $S_{3}$ foliation, and indicators of a continental arc magmatism, together with the A-type, late-post tectonic São Vicente granite and two other batoliths intruded $\sim 505 \mathrm{Ma}$ ago (more precisely 515 Ma, McGee et al., 2012).

The single mechanism available for explaining the $D_{1}-D_{2}-D_{3 P}$ deformation (SE-NW compression) in the whole Paraguay belt is the collision of the western margin of the Paraná block with the eastern margin of the Amazon-Rio Apa paleo-continent. Moreover, because the Brasiliano Cycle compression also propagated into the Tucavaca aulacogen and crystalline basement (Jones, 1985; Litherland et al., 1989) we may envisage the SW-NE compression in the rocks of the Corumbá area $\left(D_{3 T}\right.$; this paper) as a consequence of the relative movement of the SW margin of the Tucavaca aulacogen (the part of the Rio Apa block hidden beneath Phanerozoic sediments; Fig. 1b) against the NE margin. Exactly because the continental collision was the primary cause of all contraction along the Amazon-Rio Apa paleo-margin and its close interior, $D_{3 P}$ shortening lasted longer than $\mathrm{D}_{3 \mathrm{~T}}$. The lack of a shortening similar to $\mathrm{D}_{3 \mathrm{~T}}$ in the Bodoquena Range area (comparing with Campanha et al., 2010, 2011), therefore a region out of the influence of the Tucavaca aulacogen, further supports this interpretation. Additionally, $\mathrm{D}_{3 \mathrm{~T}}$ may have been at least in part due to tectonic escape associated to the strong regional compression $\left(D_{3 P}\right)$, such as reported elsewhere in the northern Paraguay belt (see above).

The models used by Campanha et al. $(2011,2010)$ and Godoy et al. (2010) as attempts to explain the Paraguay belt only address the respective areas of study and do not regard the different tectonic transports in areas adjacent to each other. Although the tectonic transport to SE in part of the northern Paraguay belt and along the Cuiabá-Bonito strip of Cuiabá Group rocks may be a consequence of back-thrusting in an overall regime of NW-verging (craton-verging) frontal ramps (D'el-Rey Silva, 1990a,b), the close occurrence of rocks of the Paraguay and Brasília belts to the East of Nova Xavantina (Fig. 1a) and also the Cuiabá Group rocks pushed onto the Goiás magmatic arc demands another explanation and caution, because the two belts are entirely different in age.

Thus, should the treatment of the new structural data in the Corumbá area consider the structural evolution in other parts of the belt, it is necessary to understand first the nature of the basin precursor of the Paraguay belt and on the ways it could be tectonically inverted. This is the subject of the companion paper (Part II). 


\section{Acknowledgments}

Geologists Augusto Mendonça (former Director; VETRIA Mine), Rafael Henchen, and Felixberto Santiago, as well as Geographer Aguinaldo Silva provided strong support in Corumbá (2012-2013). Geologists Larissa Valadão and Vitor Katalinik received advanced training in structural geology and geological mapping during the field work. Davi Saldanha thanks CNPQ for the current MSc scholarship. The two papers (Part I and Part II) integrate the Project Neoproterozoic Tectonic Evolution of the São Francisco Craton and Marginal Belts (Coordinator: L. D'el-Rey Silva) and also the Ediacarian Project, (Coordinator: D.H-G Walde) source of funds allocated by PETROBRAS. Three anonymous reviewers and Prof. Rob Govers (Utrecht University) are deeply thanked for several suggestions and references that strengthened this paper to the most.

\section{References}

Abreu Filho, W., Luz, J.S., 1977. Projeto Província Serrana, Relatório de Progresso. CPRM Giânia Vols. I-II (63 pp.).

Almeida, F.F.M., 1964. Geologia do Centro-Oeste Matogrossense. DNPM, Divisão de Geologia e Mineralogia, Boletim 150 (92 pp.).

Almeida, F.F.M. de, Hasui, Y., Brito Neves, B.B. de, Fuck, R.A., 1981. Brazilian structural provinces: an introduction. Earth Sci. Rev. 17, 1-29.

Alvarenga, C.J.S.de, Trompette, R., 1993. Evolução Tectônica Brasiliana da Faixa Paraguai: A Estruturação da Região de Cuiabá. Rev. Bras. Geosci. 23 (1), 18-30.

Alvarenga, C.J.Sde, Moura, C.A.V., Gorayeb, P.S., de S., Abreu, de, F.A.M., 2000. Paraguay and Araguaia Belts. In: Cordani, U.G., Milani, E.J., Thomaz Filho, A., Campos, D.A. (Eds.), Tectonic Evolution of South America, 31 International Geological Congress, Rio, pp. 183-193.

Alvarenga, C.J.S., Santos, R.V., Dantas, E.L., 2004. C-O-Sr isotopic stratigraphy of cap carbonates overlying Marinoan-age glacial diamictite in the Paraguay belt, Brazil. Precambrian Res. 131, 1-21.

Alvarenga, C.J.S.de, Figueiredo, M.F., Babinski, M., Pinho, F.C., 2007. Glacial diamictites of Serra Azul Formation (Ediacarian, Paraguay belt): evidence of the Gaskyers glacial event in Brazil. J. S. Am. Earth Sci. 23, 236-241.

Alvarenga, C.J.S.de, Boggiani, P.C., Babinski, M., Dardenne, M.A., Figueiredo, M.F., Dantas, E.L., Uhlein, A., Santos, R.V., Sila, A.N., Trompette, R., 2011. Glacially influenced sedimentation of the Puga Formation, Cuiabá Group and Jacadigo Group, and associated carbonates of the Araras and Corumbá groups, Paraguay belt, central Brazil. Geological Society London, Memoirs 2011 v.36, pp. 487-497. http://dx.doi. org/10.1144/M36.45.

Angerer, T., Hagemann, S.G., Walde, D.H.-G., Halverson, G.P., Boyce, A.J., 2015. Genesis of the Santa Cruz Neoproterozoic Hematite Deposit, Corumbá, Brazil: Depositional, Diagenetic, and Supergene Iron Upgrade. Submitted to Economic Geology (Oct/2014).

Babinski, M., Boggiani, P.C., Fanning, C.M., Fairchild, T.R., Simon, C.M., Sial, A.N., 2008. U$\mathrm{Pb}$ SHRIMP Geochronology and Isotope Chemostratigraphy (C, O, SR) of the Tamengo Formation, Southern Paraguay Belt, Brazil. Short Paper Presented in the VI South American Symposium on Isotope Geology, Bariloche - Argentina. PDF file available in CD-ROM.

Babinski, M., Boggiani, P.C., Trindade, R.I.F., Fanning, C.M., 2013. Detrital zircon ages and geochronological constraints on the Neoproterozoic Puga diamictite and associated BIFs in the southern Paraguay Belt, Brazil. Gondwana Res. 23, 988-997. http://dx. doi.org/10.1016/j.gr.2012.06.011.

Bandeira, J., McGee, B., Nogueira, A.C.R., Collins, A.S., Trindade, R., 2012. Sedimentological and provenance response to Cambrian closure of the Clymene Ocean: the upper Alto Paraguay Group, Paraguay belt, Brazil. Gondwana Res. 21, 324-340. http://dx.doi.org/ 10.1016/j.gr.2011.04.006

Boggiani, P.C., Gaucher, C., Sial, A.N., Babinski, M., Simon, C.M., Riccomini, C., Pereira, V.P., Fairchild, T.R., 2010. Chemostratigraphy of the Tamengo Formation (Corumbá Group; Brazil): a contribution to the calibration of the Ediacarian carbon-isotope curve. Precambrian Res. 182, 382-401. http://dx.doi.org/10.1016/j.precamres.2010.06.003.

Campanha, G.A.C., Lucas, W., Boggiani, P.C., Grohman, C.H., Cáceres, A.A., 2010. Structural analysis of the Itapucumí Group in the Vallemí region, northern Paraguay: evidence of a new Brasiliano/Pan-African mobile belt. J. S. Am. Earth Sci. 30, 1-11. http://dx. doi.org/10.1016/j.jsames.2010.04.001.

Campanha, G.A.C., Boggiani, P.C., Sallun Filho, W., Sá, F.S., Zuquim, M.P.S., Piacentini, T., 2011. The Paraguay Fold Belt in the Serra da Bodoquena and Miranda River Depression, Mato Grosso do Sul. Revista do Instituto de Geociências - USP 11 (3), 79-96.

Castro, D.L. de, Fuck, R.A., Phillips, J.D., Vidotti, R.M., Bezerra, F.H.R., Dantas, E.L., 2014. Crustal structure beneath the Paleozoic Parnaiba Basin revealed by airborne gravity and magnetic data, Brazil. Tectonophysics 614, 128-145. http://dx.doi.org/10.1016/ j.tecto.2013.12.009.

Cordani, U.G., Teixeira, W., Tassinari, C.G., Coutinho, J.M.V., Ruiz, A.S., 2010. The Rio Apa Craton in Mato Grosso do Sul (Brazil) and Northern Paraguay: geochronological evolution, correlations and tectonic implications for Rodinia and Gondwana. Am. J. Sci. 310, 981-1023. http://dx.doi.org/10.2475/09.2010.09.
Cordani, U.G., Pimentel, M.M., Araújo, C.E.G., Fuck, R.A., 2013. The significance of the Transbrasiliano-Kandi tectonic corridor for the amalgamation of West Gondwana. Brazil. J. Geol. 43 (3), 583-597. http://dx.doi.org/10.5327/Z2317-48892013000300012.

Cordeiro, P.F. de O., Oliveira, C.G., Della Giustina, M.E.S., Dantas, E.L., Santos, R.V., 2014. The Paleoproterozoic Campinorte Arc: tectonic evolution of a Central Brazil pre-Columbia orogeny. Precambrian Res. 251, 49-61. http://dx.doi.org/10.1016/j.precamres.2014. 06.002.

Curto, J.B., Vidotti, R.M., Blakely, R.J., Fuck, R.A., 2015. Crustal framework of the northwest Paraná Basin, Brazil: Insights from joint modeling of magnetic and gravity data. Tectonophysics http://dx.doi.org/10.1016/j.tecto.2015.05.011.

Dantas, E.L., Martinelli, C.C., 2003. Nd isotopes from the Araés Metavocano-sedimentary sequence in the Paraguay Belt, Nova Xavantina, Mato Grosso, Central Brazil. SOUTH AMERICAN SYMPOSIUM ON ISOTOPE GEOLOGY, 4., Salvador. CBPM/IRD, 2003. v. 1, pp. $168-169$.

Dantas, E.L., Alvarenga, C.J.S. de, Santos, R.V. Pimentel, M.M. 2009. Using Nd isotopes to understand the provenance of sedimentary rocks from a continental margin to a foreland basin in the Neoproterozoic Paraguay belt, Central Brazil. Precambrian Res. 170 1-12. http://dx.doi.org/10.1016/j.precamres.2008.11.005.

D'el-Rey Silva, L.J.H., 1990a. Ouro no Grupo Cuiabá, Mato Grosso, Brasil: Controle estrutural e implicações tectônicas. XXXVI Congresso Brasileiro de Geologia, Natal/ RN, Anais SBG, Vol.6, pp. 2520-2535 (Text in English).

D'el-Rey Silva, L.J.H.. 1990b. Structural controls on gold mineralization in the Paraguay Fold Belt, Brazil. GAC/MAC Annual Meeting, Vancouver/Canada 1990, Programme with Abstracts, A122. Poster presentation.

D'el-Rey Silva, L.J.H., 2008. Underthrusting and Late Proterozoic Crustal-Scale Pop-Up in the Brasília Belt, central Brazil. In: De Santis, Angelo, et al. (Eds.), (2008), Proceedings of the 1st WSEAS International Conference on Environmental and Geological Sciences and Engineering (EG'08), Malta, September, 11th-13th, 143-148 (ISBN: 978-960474-001-7; ISSN: 1790-5095. In CD-ROM: folder eg, file EG18.pdf. http://www. wseas.org/online).

D'el-Rey Silva, L.J.H., Klein, P.B.W., Walde, D.G.H., 2004. The Caldas Novas Dome, Goiás: structural evolution and implications for tectonics in the Brasília Belt, Brazil. J. S. Am. Earth Sci. 17 (2), 153-169. http://dx.doi.org/10.1016/j.sames.2004.03.001.

D'el-Rey Silva, L.J.H., Vasconcelos, M.A.R., Gonçalves, D.V., 2008. Timing and role of the Maranhão River Thrust in the evolution of the Neoproterozoic Brasília Belt and Tocantins Province, Central Brazil. Gondwana Res. 13 (3), 352-372. http://dx.doi. org/10.1016/j.gr.2007.09.004

D'el-Rey Silva, L.J.H., Oliveira, I., L. de, Pohren, C.B., Tanizaki, M.L.N., Carneiro, R.C., Fernandes, G.L. de F., Aragão, Priscila E., 2011. Coeval perpendicular shortenings in the Brasília belt: collision of irregular plate margins leading to oroclinal bending in the Neoproterozoic of central Brazil. J. S. Am. Earth Sci. 32 (1), 1-13. http://dx.doi. org/10.1016/j.jsames.2011.02.013.

Dorr, J. Van N.2.D. 1944. Manganese and iron deposits of Morro do Urucum, Mato Grosso, Brazil. United States Department of the Interior, USGS, Bulletin. 946-A, pp. 1-47.

Figueiredo, M.F., Babinski, M., Alvarenga, C.J.S., Pinho, F.E.C., 2008. New Lithostratigraphic Unit Records an Ediacarian glaciation in Mato Grosso State, Brazil: Serra Azul formation. Revista do Instituto de Geociências - USP 8 (2), 65-75.

Fuck, R.A., Pimentel, M.M., D'el-Rey Silva, L.J.H., 1994. Compartimentação Tectônica na Porção Oriental da Província Tocantins. In XXXVIII Congresso Brasileiro de Geologia, Camboriú, SBG. Boletim Resumos Expandidos SBG 1,215-217.

Fuck, R.A., Pimentel, M.M., Soares, J.E.P., Dantas, E.L., 2006. Faixa Brasília: Uma revisão XLIII Congresso Brasileiro de Geologia, Aracaju, Anais SBG, SO4:AO-073, p. 27.

Godoi, H.O., Martins, E.G., Mello, J.C.R., Scislewski, G., 2001. Programa Levantamentos Geológicos Básicos do Brasil - PLGB. Corumbá - Folha SE21-Y-D, Aldeia Tomázia Folha SF21-V-B, Porto Murtinho - Folha SF21-V-B, Estado do Mato Grosso do Sul. Escala 1:250.000. Brasília: CPRM/DIEDIC/DEPAT.

Godoy, A.M., Pinho, F.E.C., Manzano, J.C., Araújo, L.M.B., Silva, J.A., Figueiredo, M., 2010 Estudos isotópicos das rochas granitóides neoproterozóicas da Faixa de Dobramento Paraguai. Rev. Bras. Geosci. 40 (3), 380-391.

Herz, N., Hasui, Y., Sena Costa, J.B., Silva Matta, M.A. da, 1989. The Araguaia Fold Belt Brazil: a reactivated Brasiliano-Pan-African cycle (550 Ma) geosuture. Precambrian Res. 42, 371-386.

Jones, J.P., 1985. The Southern Border of the Guaporé Shield in Western Brazil and Bolívia: an interpretation of its geological evolution. Precambrian Res. 28, 111-135.

Litherland, M., Annels, R.N., Darbyshire, D.P.F., Fletcher, C.J.N., Hawkins, M.P., Klink, B.A. Mitchell, W.I., O'Connor, E.A., Pitfield, P.E.J., Power, G., Webb, B.C., 1989. The Proterozoic of Eastern Bolivia and its relationship to the Andean Mobile Belt. Precambrian Res. 43, 157-174.

Luz, J.S., Oliveira, A.M., Souza, J.O., Motta, J.F.M., Tanno, L.C., Carmo, L.S., Souza, N.B., 1980 Projeto Coxipó. Relatório Final. Goiânia, DNPM/CPRM. v. 1 (136 pp.).

Mantovani, M.S.M., Brito Neves, B.B. de, 2005. The paranapanema lithospheric block: its importance for Proterozoic (Rodinia, Gondwana) supercontinent theories. Gondwana Res. 8 (3), 303-315.

Marques, F.O., Nogueira, F.C.C., Bezerra, F.H.R., de Castro, D.I., 2014. The Araripe Basin in NE Brazil: an intracontinental graben inverted to a high-standing horst. Tectonophysics 630, 251-264. http://dx.doi.org/10.1016/j.tecto.2014.05.029.

McClay, K.R., Buchanan, P.G., 1992. Thrust faults in inverted extensional basins. In McClay, K.R. (Ed.), Thrust Tectonics. Chapman \& Hall, pp. 93-104.

McGee, B., Collins, A.S., Trindade, R.I.F., 2012. G'day Gondwana - the final accretion of a supercontinent: U-Pb ages from the post-orogenic São Vicente Granite, northern Paraguay belt, Brazil. Gondwana Res. 21, 316-322. http://dx.doi.org/10.1016/j.gr. 2011.04.011.

Paixão, M.A.P., Nilson, A.A., and Dantas, E.L., 2008. The Neoproterozoic Quatipuru Ophiolite and the Araguaia fold belt, central-northern Brazil, compared with correlatives in NW Africa. Geol. Soc. Lond. Spec. Publ., v. 294, p.297-318; http://dx.doi.org/ 10.1144/SP294.16. 
Piacentini, T., Vasconcelos, P.M., Farley, K.A., 2013. 40Ar/39Ar constraints on the age and thermal history of the Urucum Neoproterozoic banded iron-formation, Brazil. Precambrian Res. 228, 48-62. http://dx.doi.org/10.1016/j.precamres.2013.01.002.

Pimentel, M.M., Fuck, R.A., Gioia, S.M.C.L., 2000. The Neoproterozoic Goiás magmatic arc, Central Brazil: A review and New Sm-Nd isotopic data. Rev. Bras. Geosci. 30 (1), 035-039.

Ramsay, J.G., 1967. Folding and Fracturing of Rocks. McGraw-Hill Book Company (568 pp.). Ruiz, A.S., 2005. Evolução Geológica do Sudoeste do Cráton Amazônico Região Limítrofe Brasil-Bolívia - Mato Grosso. Unpublished PhD Thesis, UNESP Rio Claro, 299p.

Silva, C.H., Simões, L.S.A., Ruiz, A.S., 2002. Caracterização dos Veios de Quartzo Auríferos da Região de Cuiabá (MT). Rev. Bras. Geosci. 32 (4), 407-418.

Trompette, R., 1994. Geology of Western Gondwana. A.A. Balkema, Rotterdam (350 pp.).

Trompette, R., Alvarenga, C.J.S. de, Walde, D.H.-G., 1998. Geological evolution of the Neoproterozoic Corumbá graben system (Brazil). Depositional context of the stratified Fe and Mn ores of the Jacadigo Group. J. S. Am. Earth Sci. 11 (6), 587-597.
Ussami, N., Molina, E.C., 1999. Flexural modeling of the Neoproterozoic Araguaia belt, central Brazil. J. S. Am. Earth Sci. 12, 87-98.

Vasconcelos, B.R., Ruiz, A.S., Matos, J.B., 2015. Polyphase deformation and metamorphism of the Cuiabá group in the Poconé region (MT), Paraguay Fold and Thrust Belt: kinematic and tectonic implications. Brazilian Journal of Geology 45 (1), 51-63. http://dx. doi.org/10.1590/23174889201500010004.

Walde, D. H. G., 1988. Das Proterozoische Paraguay-Araguaia orógeno in WestBrasilien, ausgehend von untersuchugen im Raum Corumbá. Habilitationsschrift, Albert-Ludwigs Univ., Freiburg. 122 pp. unpublished

Walde, D.H.-G., Do Carmo, D.A., Guimarães, E.M., Vieira, L.C., Erdtmann, B.D., Sanchez, E., 2015. New Aspects of the Neoproterozoic-Cambrian Transition in the Corumbá Region (State of Mato Grosso do Sul, Brazil). Submitted to Annales de Paléontologie, Special Issue Morocco Congress 2014 (under review). 